In cooperation with the Wisconsin Department of Natural Resources

\title{
Geomorphic, Flood, and Groundwater-Flow Characteristics of Bayfield Peninsula Streams, Wisconsin, and Implications for Brook-Trout Habitat
}

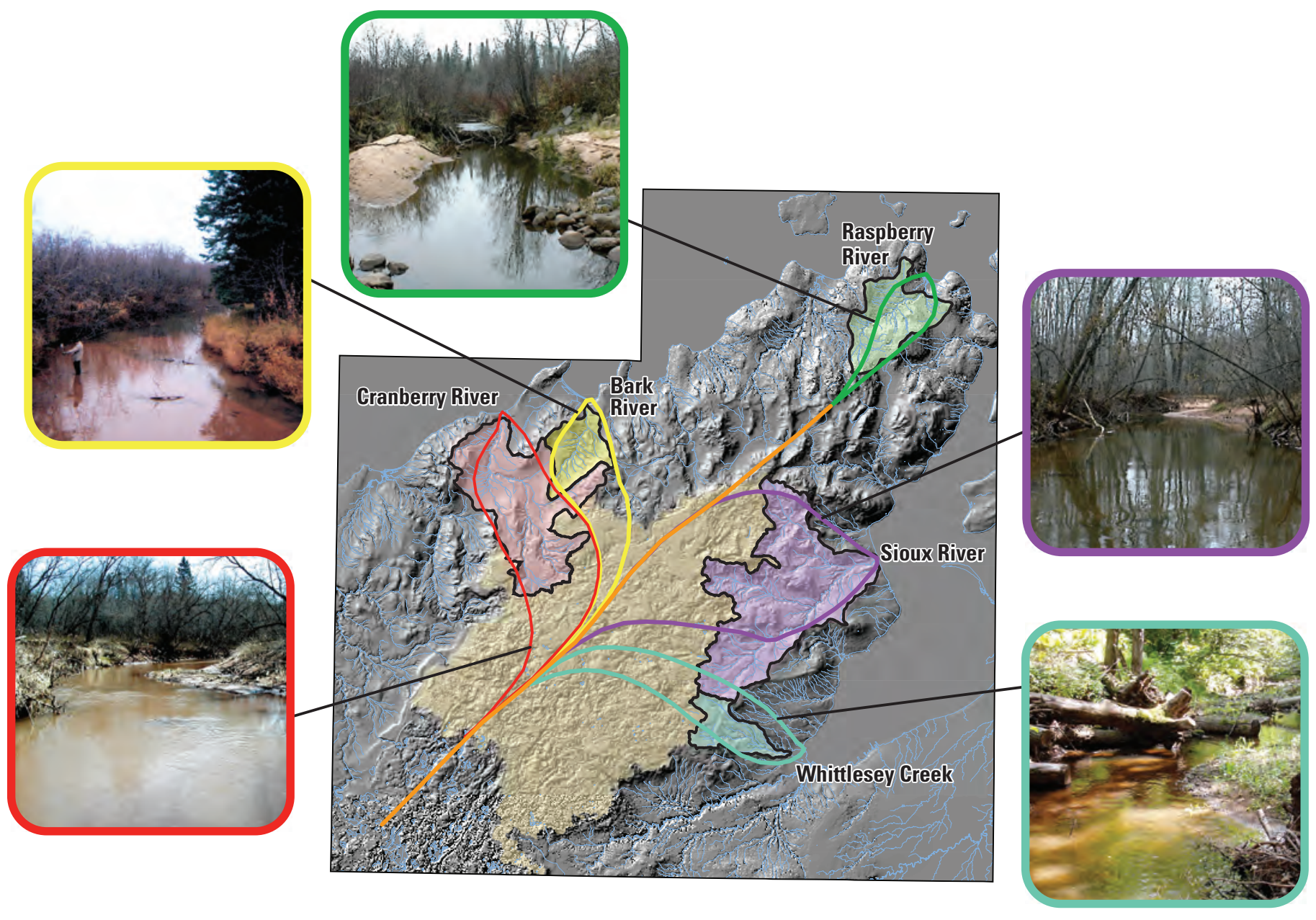

Scientific Investigations Report 2014-5007 



\section{Geomorphic, Flood, and Groundwater- Flow Characteristics of Bayfield Peninsula Streams, Wisconsin, and Implications for Brook-Trout Habitat}

By Faith A. Fitzpatrick, Marie C. Peppler, David A. Saad, Dennis M. Pratt, and Bernard N. Lenz

In cooperation with the Wisconsin Department of Natural Resources

Scientific Investigations Report 2014-5007 


\title{
U.S. Department of the Interior SALLY JEWELL, Secretary
}

\section{U.S. Geological Survey Suzette M. Kimball, Acting Director}

\author{
U.S. Geological Survey, Reston, Virginia: 2015
}

For more information on the USGS - the Federal source for science about the Earth, its natural and living resources, natural hazards, and the environment, visit http://www.usgs.gov or call 1-888-ASK-USGS.

For an overview of USGS information products, including maps, imagery, and publications, visit http://www.usgs.gov/pubprod

To order this and other USGS information products, visit http://store.usgs.gov

Any use of trade, firm, or product names is for descriptive purposes only and does not imply endorsement by the U.S. Government.

Although this information product, for the most part, is in the public domain, it also may contain copyrighted materials as noted in the text. Permission to reproduce copyrighted items must be secured from the copyright owner.

Suggested citation:

Fitzpatrick, F.A., Peppler, M.C., Saad, D.A., Pratt, D.M., and Lenz, B.N., 2015, geomorphic, flood, and groundwater-flow characteristics of Bayfield Peninsula streams, Wisconsin, and implications for brook-trout habitat: U.S. Geological Survey Scientific Investigations Report 2014-5007, 80 p., http://dx.doi.org/10.3133/sir20145007.

ISSN 2328-0328 (online) 


\section{Contents}

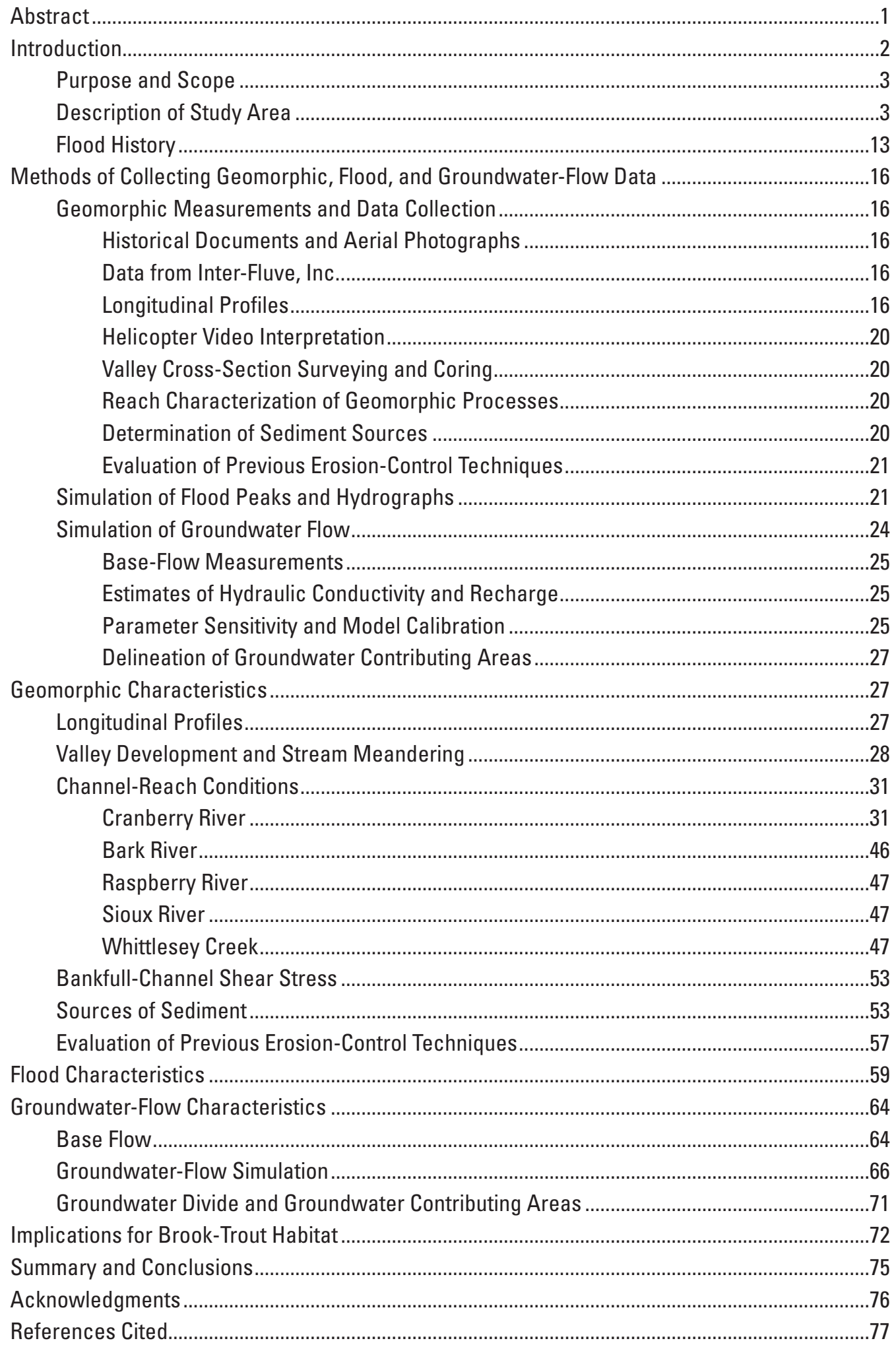




\section{Figures}

1. Maps showing locations of studied streams and sites in the Bayfield Peninsula, Wisconsin

2. Map showing distribution of brook-trout fingerlings in Bayfield Peninsula streams, 2004

3. Map showing digital elevation model of the Bayfield Peninsula, Wisconsin ...................7

4. Map showing Quaternary geologic deposits for the Bayfield Peninsula, Wisconsin ......9

5. Schematic cross section showing generalized geology and conceptual model of the deep groundwater-flow system of the Bayfield Peninsula, Wisconsin

6. Geologic cross section through the southern part of the Whittlesey Creek Basin, Bayfield Peninsula, Wisconsin ..........................................................................................11

7. Map showing soil types of the Bayfield Peninsula, Wisconsin .....................................12

8. Map showing land cover (1992-93) for the Bayfield Peninsula, Wisconsin....................14

9. Graphs showing flood peaks for the Sioux River, Whittlesey Creek, North Fish Creek, Bois Brule River, and Bad River flood-peak data from annual and partial-duration series .

10. Map showing hydrologic features simulated with analytic elements for the GFLOW model of the Bayfield Peninsula, Wisconsin

11. Graph showing comparison of longitudinal profiles for six Bayfield peninsula streams

12. Schematic diagrams showing valley development and types of meandering for Bayfield Peninsula streams .29

13. Map and graph showing Cranberry River and longitudinal profile ..................................30

14. Map and graph showing Bark River and longitudinal profile ..........................................32

15. Map and graph showing Raspberry River and longitudinal profile ..................................34

16. Map and graph showing Sioux River and longitudinal profile ..........................................36

17. Map and graph showing Whittlesey Creek and longitudinal profile ................................38

18. Map showing differences in stream network development and channel widths in the Cranberry River Basin between 1852 General Land Office Survey maps, USGS 7.5-minute topographic maps, and 2002-2003 field surveys ...........................................46

19. Cross sections and sediment cores at site 41 (East Fork Cranberry River) and site 63 (Lenawee Creek)

20. Cross sections and sediment cores at site 46 (East Fork Cranberry River) .....................50

21. Diagram showing longitudinal profile and valley development for Bayfield Peninsula streams in response to episodic lowering of postglacial lake levels .52

22. Cross sections, bank and terrace cut geologic descriptions, and sediment cores at site 50 (Cranberry River)...

23. Photograph showing buried root crown at site 50 along the Cranberry River, Wisconsin

24. Cross sections and sediment cores at site 30 along the Cranberry River ......................58

25. Cross sections and sediment cores from North Fish Creek, Wisconsin ..........................60

26. Cross section and sediment cores at site 2 along Whittlesey Creek .............................62 
27. Graph showing bankfull-channel shear stress and median sediment size for selected sites on Bayfield streams...

28. Photographs showing two Red Clay Interagency Committee sites before and after installation of erosion-control techniques...

29. Flood hydrographs for the 2-, 10-, and 100-year 24-hour rainfalls for the Cranberry River, Wisconsin

30. Map showing distribution of unit-area base flow for streams on the Bayfield Peninsula, Wisconsin, November 2002

31. Graphs showing relation of measured and simulated head and base flow for the calibrated GFLOW model for Bayfield Peninsula, Wisconsin

32. Graph showing GFLOW groundwater-flow model parameter sensitivities from UCODE for the Bayfield Peninsula, Wisconsin study area

33. Map showing groundwater contours and contributing areas simulated by the GLFOW model for five Bayfield Peninsula streams, Wisconsin

\section{Tables}

1. Drainage-area, soil-texture, and land-cover characteristics of five streams, Bayfield Peninsula, Wisconsin

2. Sites sampled in 2002-2003 as part of the study of the geomorphic, flood, and groundwater-flow characteristics of Bayfield Peninsula streams, Wisconsin

3. Physical characteristics of subbasins used in the Cranberry River HEC-1 flood hydrograph simulations, Bayfield Peninsula, Wisconsin.

4. HEC-1 model input-parameter values for Cranberry River, Wisconsin for four land-cover simulations

5. Percentages of land-cover types used in the Cranberry River, Wisconsin from HEC-1 model simulations

6. Comparison of average and range of slopes for selected Bayfield Peninsula streams, Wisconsin, based on longitudinal profiles

7. Summary of geomorphic characteristics and processes by altitude for five Bayfield Peninsula streams, Wisconsin

8. Relative contributions of sediment from seven sources to Bayfield Peninsula streams, Wisconsin.

9. Flood peaks and total storm volume from SCS-design storms for HEC-1 flood hydrograph simulations of four land-cover scenarios, Cranberry River, Wisconsin ......66

10. Results of field investigations of base flow and streambed temperature for Bayfield Peninsula streams, Wisconsin, 2002

11. Initial estimate and UCODE-optimized parameters used in the GFLOW model for Bayfield Peninsula, Wisconsin

12. Head fit statistics and sum of square weighted residuals for the initial and calibrated GFLOW model for Bayfield Peninsula, Wisconsin 


\section{Conversion Factors}

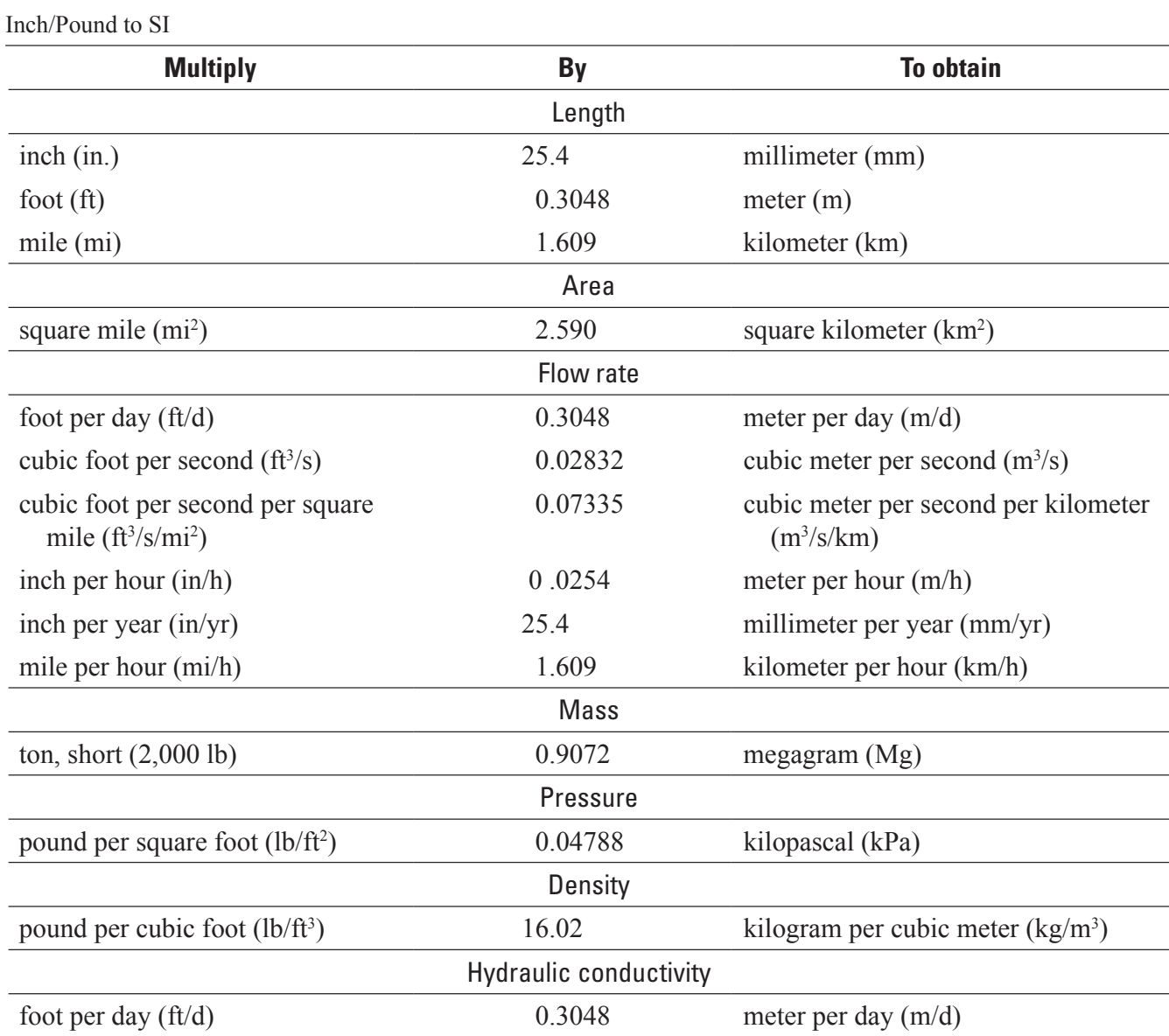

Temperature in degrees Fahrenheit $\left({ }^{\circ} \mathrm{F}\right)$ may be converted to degrees Celsius $\left({ }^{\circ} \mathrm{C}\right)$ as follows: ${ }^{\circ} \mathrm{C}=\left({ }^{\circ} \mathrm{F}-32\right) / 1.8$

Vertical coordinate information is referenced to the National Geodetic Vertical Datum of 1929 (NGVD 29).

Horizontal coordinate information is referenced to the North American Datum of 1983 (NAD 83).

Altitude, as used in this report, refers to distance above the vertical datum. 
SI to Inch/Pound

\begin{tabular}{|c|c|c|}
\hline Multiply & By & To obtain \\
\hline \multicolumn{3}{|c|}{ Length } \\
\hline centimeter $(\mathrm{cm})$ & 0.3937 & inch (in.) \\
\hline millimeter (mm) & 0.03937 & inch (in.) \\
\hline meter $(\mathrm{m})$ & 3.281 & foot $(\mathrm{ft})$ \\
\hline kilometer (km) & 0.6214 & mile (mi) \\
\hline meter $(\mathrm{m})$ & 1.094 & yard (yd) \\
\hline \multicolumn{3}{|c|}{ Area } \\
\hline square kilometer $\left(\mathrm{km}^{2}\right)$ & 0.3861 & square mile $\left(\mathrm{mi}^{2}\right)$ \\
\hline \multicolumn{3}{|c|}{ Flow rate } \\
\hline cubic meter per second $\left(\mathrm{m}^{3} / \mathrm{s}\right)$ & 70.07 & acre-foot per day (acre-ft/d) \\
\hline cubic meter per year $\left(\mathrm{m}^{3} / \mathrm{yr}\right)$ & 0.000811 & acre-foot per year (acre-ft/yr) \\
\hline meter per second $(\mathrm{m} / \mathrm{s})$ & 3.281 & foot per second (ft/s) \\
\hline meter per minute $(\mathrm{m} / \mathrm{min})$ & 3.281 & foot per minute (ft/min) \\
\hline meter per hour (m/hr) & 3.281 & foot per hour (ft/hr) \\
\hline meter per day (m/d) & 3.281 & foot per day (ft/d) \\
\hline meter per year (m/yr) & 3.281 & foot per year ft/yr) \\
\hline cubic meter per second $\left(\mathrm{m}^{3} / \mathrm{s}\right)$ & 35.31 & cubic foot per second $\left(\mathrm{ft}^{3} / \mathrm{s}\right)$ \\
\hline $\begin{array}{l}\text { cubic meter per second per square } \\
\text { kilometer }\left[\left(\mathrm{m}^{3} / \mathrm{s}\right) / \mathrm{km}^{2}\right]\end{array}$ & 91.49 & $\begin{array}{l}\text { cubic foot per second per square } \\
\text { mile }\left[\left(\mathrm{ft}^{3} / \mathrm{s}\right) / \mathrm{mi}^{2}\right]\end{array}$ \\
\hline cubic meter per day $\left(\mathrm{m}^{3} / \mathrm{d}\right)$ & 35.31 & cubic foot per day $\left(\mathrm{ft}^{3} / \mathrm{d}\right)$ \\
\hline cubic meter per hour $\left(\mathrm{m}^{3} / \mathrm{h}\right)$ & 39.37 & inch per hour (in/h) \\
\hline millimeter per year (mm/yr) & 0.03937 & inch per year (in/yr) \\
\hline kilometer per hour $(\mathrm{km} / \mathrm{h})$ & 0.6214 & mile per hour $(\mathrm{mi} / \mathrm{h})$ \\
\hline \multicolumn{3}{|c|}{ Mass } \\
\hline megagram (Mg) & 1.102 & ton, short $(2,000 \mathrm{lb})$ \\
\hline megagram per year $(\mathrm{Mg} / \mathrm{yr})$ & 1.102 & ton per year (ton/yr) \\
\hline metric ton per year & 1.102 & ton per year (ton/yr) \\
\hline \multicolumn{3}{|c|}{ Pressure } \\
\hline kilopascal (kPa) & 20.88 & pound per square foot $\left(\mathrm{lb} / \mathrm{ft}^{2}\right)$ \\
\hline \multicolumn{3}{|c|}{ Density } \\
\hline kilogram per cubic meter $\left(\mathrm{kg} / \mathrm{m}^{3}\right)$ & 0.06242 & pound per cubic foot $\left(\mathrm{lb} / \mathrm{ft}^{3}\right)$ \\
\hline gram per cubic centimeter $\left(\mathrm{g} / \mathrm{cm}^{3}\right)$ & 62.4220 & pound per cubic foot $\left(\mathrm{lb} / \mathrm{ft}^{3}\right)$ \\
\hline \multicolumn{3}{|c|}{ Hydraulic conductivity } \\
\hline meter per day $(\mathrm{m} / \mathrm{d})$ & 3.281 & foot per day (ft/d) \\
\hline
\end{tabular}

Temperature in degrees Celsius $\left({ }^{\circ} \mathrm{C}\right)$ may be converted to degrees Fahrenheit $\left({ }^{\circ} \mathrm{F}\right)$ as follows:

${ }^{\circ} \mathrm{F}=\left(1.8 x^{\circ} \mathrm{C}\right)+32$ 



\title{
Geomorphic, Flood, and Groundwater-Flow Characteristics of Bayfield Peninsula Streams, Wisconsin, and Implications for Brook-Trout Habitat
}

\author{
By Faith A. Fitzpatrick, Marie C. Peppler, David A. Saad, Dennis M. Pratt, ${ }^{1}$ and Bernard N. Lenz ${ }^{2}$
}

\section{Abstract}

In 2002-03, the U.S. Geological Survey conducted a study of the geomorphic, flood, and groundwater-flow characteristics of five Bayfield Peninsula streams, Wisconsin (Cranberry River, Bark River, Raspberry River, Sioux River, and Whittlesey Creek) to determine the physical limitations for brook-trout habitat. The goals of the study were threefold: (1) to describe geomorphic characteristics and processes, (2) to determine how land-cover characteristics affect flood peaks, and (3) to determine how regional groundwater flow patterns affect base flow.

The geomorphic characterization consisted of analyses of historical aerial photographs and General Land Office Survey notes, observations from helicopter video footage, surveys of valley cross sections, and coring. Sources of sediment were identified from the helicopter video and field surveys, and past erosion-control techniques were evaluated. Geomorphic processes, such as runoff sediment erosion, transport, and deposition, are driven by channel location within the drainage network, texture of glacial deposits, and proximity to postglacial lake shorelines; these processes have historically increased because of decreases in upland forest cover and channel roughness. Sources of sediment for all studied streams mainly came from bank, terrace, or bluff erosion along main stem reaches and along feeder tributaries that bisect mainstem entrenched valley sides. Bluff, terrace, and bank erosion were the major sources of sediment to Whittlesey Creek and the Sioux River. No active bluff erosion was observed on the Cranberry River or the Bark River but anecdotal information suggests that landslides occasionally happen on the Cranberry River. For the Bark River, sources of sediment were somewhat evenly divided among road crossings (bridges, culverts, and unimproved forest lanes), terrace erosion, bank erosion, and incision along upper main stems and feeder channels along valley sides. Evaluation of past erosion-control techniques indicated that bluffs were stabilized by a combination of artificial hardening and bioengineering of the bluff base and reducing mass wasting of the tops of the bluffs.

Flood hydrographs for the Cranberry River were simulated for four land-cover scenarios-late 20th century (1992-93), presettlement (before 1870), peak agriculture (1928), and developed (25 percent urban). Results were compared to previous simulations of flood peaks for Whittlesey Creek and for North Fish Creek (southern adjacent basin to Whittlesey Creek). Even though most uplands are presently forested, flood peaks simulated for 1992-93 were 1.5 to 2 times larger than presettlement flood peaks. The increased flood peaks caused (1) increased incision along upper main stems and tributaries that bisect entrenched valley sides, (2) bluff and terrace erosion along reaches with entrenched valleys, (3) overbank deposition and bar formation in middle and lower main stems, and (4) aggradation in mouth areas.

A base-flow survey was conducted and a groundwaterflow model was developed for the Bayfield Peninsula to delineate groundwater contributing areas. A deep aquifer system, which includes thick deposits of sand and the upper part of the bedrock, is recharged through the permeable sands in the center of the peninsula. Base flow is unevenly distributed among the Bayfield streams and depends on the amount of channel incision and the proximity of the channels to the recharge area and coarse outwash deposits. Groundwater contributing areas for the five streams do not coincide with surfacewater-contributing areas. About 89 percent of total recharge to the deep aquifer system discharges to Bayfield streams; the remaining 11 percent directly discharges to Lake Superior. Historical land-cover changes have had negligible effects on groundwater-flow from the deep aquifer system.

Available brook-trout habitat is dependent on the locations of groundwater upwellings, the sizes of flood peaks, and sediment loads. Management practices that focus on reducing or slowing runoff from upland areas and increasing channel roughness have potential to reduce flood peaks, erosion, and sedimentation and improve brook-trout habitat in all Bayfield Peninsula streams.

${ }^{1}$ Formerly Wisconsin Department of Natural Resources.

${ }^{2}$ Formerly U.S. Geological Survey. 


\section{Introduction}

Aquatic habitat in many streams that flow into Lake Superior along Bayfield Peninsula, Wis. (fig. 1A), is degraded because of increased runoff and sedimentation problems associated with past and present land uses such as logging, forest fires, agriculture, and development of roads (Red Clay Interagency Committee, 1967; Fitzpatrick and others, 1999; Pratt, 2000). Geomorphic conditions in these streams have been altered by changes in sediment erosion, transport, and deposition caused by increased flood magnitudes (Fitzpatrick, 1998; Fitzpatrick and others, 1999; Fitzpatrick and Knox, 2001). Present flood magnitudes are higher than they were before Euro-American settlement and logging in the 1870s (Verry, 1987; Fitzpatrick and others, 1999; Lenz and others, 2003).

The Bayfield streams naturally have high runoff rates because of clay soils in their drainage basins (Young and Skinner, 1974), yet many of the streams also have abundant base flow because of their connection to a deep groundwater system, which includes thick deposits of sand and the upper part of the bedrock, recharged through the permeable sands in the center highland area of the peninsula (Lenz and others, 2003) (area is shown in gray on fig. 1A). The center of the peninsula has no surface runoff (note the lack of streams in the grey area on fig. $1 \mathrm{~A}$ ) because infiltration rates exceed precipitation rates (Young and Skinner, 1974). Streams intersect the deep groundwater aquifer in the middle of their basins; thus, headwater reaches have little base flow and lower main stems have abundant base flow (Lenz and others, 2003).

Most of the Bayfield streams sustain the spawning, rearing, and juvenile-growth needs for a significant lakerun trout and salmon fishery, which annually supports more than 50,000 angler trips. Species of fish include steelhead (Oncorhynchis mykis), brown trout (Salmo trutta), and coho salmon (Oncorhynchis kisutch). Additionally, these streams presently support small numbers of brook trout (Salvelinus fontinalis), the only native stream-dwelling salmonid (fig. 2). Brook-trout populations were abundant in coldwater streams before Euro-American settlement and logging of the oldgrowth forests (about 1870). Along the Bayfield peninsula coastline, migrating brook trout grew to large sizes and supported coastal fishing termed "rock trout fishing." Historically, these rock trout, termed "coasters" today, returned to the tributaries to spawn, most likely in common with the stream fish (Pratt, 2000). Both population abundance and range rapidly declined during the settlement period and have remained low since at least the 1930s, even though millions of hatcheryreared fish were stocked in those streams. By the 1930s, the decline of brook trout populations was thought to be caused by long-lasting changes accompanying settlement-reforestation with its concomitant effects upon water supply, lowering and warming of the waters, scouring of stream beds during $\log$ drives, and especially the silting over of gravel bottoms (Greene, 1935).
In the 1990s interest in the rehabilitation of coastal brook-trout populations in Lake Superior was renewed (Newman and others, 1999: Pratt, 2000). In addition to the continued interest in stocking brook trout in streams and coastal areas, fisheries biologists were interested in determining how aquatic-habitat changes were limiting brook-trout reproduction and survival. It was important to gain insight into how existing populations could be protected and develop strategies to improve stream habitat.

In 2001-02, Trout Unlimited brought together several government agencies, conservation organizations, universities, and a private consulting firm to assess the geomorphic and hydrologic conditions of several Bayfield streams, to identify potential problem areas, and to recommend rehabilitation and watershed-management strategies relating specifically to brook-trout populations. The agencies involved were the Wisconsin Department of Natural Resources (Great Lakes Protection Fund), U.S. Fish and Wildlife Service, Red Cliff Band of the Lake Superior Chippewa Indians, AshlandBayfield-Douglas-Iron County Land Conservation Department, Sigurd Olson Environmental Institute at Northland College, Inland Sea Society, U.S. Department of Agriculture Natural Resources Conservation Service, Inter-Fluve, Inc., and the U.S. Geological Survey (USGS). Five streams from the Bayfield Peninsula were selected for a detailed assessment study: the Cranberry River, Bark River, Raspberry River, Sioux River, and Whittlesey Creek (fig. 1A).

Past and present geomorphic, flood, and groundwater characteristics directly affect brook-trout habitat, and understanding the cause and effects of these on habitat was necessary prior to formulating rehabilitation and watershedmanagement strategies. The USGS study's goals were focused on these aspects for the five streams included in the larger overall multi-agency study: (1) describing the geomorphic characteristics and processes, (2) determining how land-cover characteristics affect flood peaks; and (3) determining how regional groundwater-flow patterns affect base flow. The two main purposes of the overall study were to describe the physical limitations of salmonid rehabilitation efforts and to provide background information for use by water-resources and fisheries managers to reduce runoff and erosion and to improve fish habitat.

The USGS efforts built off of previous geomorphology, flood, and groundwater studies done in the area. As part of the new study, USGS collected additional geomorphic data in 2002-03 to enhance and supplement the geomorphic data collected by Inter-Fluve, Inc. in 2002. Interpretations from the geomorphic data included identification of major causes of geomorphic processes, major sources of sediment, and evaluation of past erosion-control techniques. Effects of land-cover change on flood peaks were simulated for the Cranberry River Basin and compared to results of previous simulations for North Fish Creek and Whittlesey Creek (Fitzpatrick, 1998; Lenz and others, 2003). Last, a groundwater-flow model 
was constructed for the Bayfield Peninsula (an expansion of the Whittlesey Creek groundwater-flow model described by Lenz and others, 2003) to delineate groundwater contributing areas for the streams. Methods used in these previous studies for individual watersheds in the area were applied across the broader region to describe the physical and hydrologic limitations to brook-trout habitat throughout the Bayfield Peninsula.

\section{Purpose and Scope}

The purpose of this report is to present results from the study of geomorphic, flood, and groundwater-flow characteristics for five Bayfield Peninsula streams that flow into Lake Superior in Wisconsin. More time and effort were spent identifying geomorphic characteristics of the Cranberry River than the other studied streams. Simulations of land-cover effects on flood peaks for the Cranberry River are presented and compared to previous simulations for Whittlesey Creek and North Fish Creek. Simulated land-cover scenarios included complete forest cover before 1870 (pre-Euro-American settlement), peak agriculture (about 1928), and the present (1992-93). Groundwater-flow characteristics for the five studied streams are described through analysis of base-flow measurements and results from groundwater-flow simulations. In addition, implications of geomorphic, flood, and groundwater-flow characteristics for potential brook-trout habitat are discussed.

\section{Description of Study Area}

The Bayfield Peninsula is on the south shore of Lake Superior in Wisconsin (fig. 1A). The peninsula rises to an altitude of about $1,400 \mathrm{ft}$, or about $800 \mathrm{ft}$ above the mean water level of Lake Superior (602 ft) (fig. 3). Stream networks on the peninsula generally are oriented perpendicular to the lake shoreline. Surface-water-contributing basins are small (less than $50 \mathrm{mi}^{2}$ in area) (fig. $1 \mathrm{~A}$, table 1 ). The surface-waternoncontributing area in the center of the peninsula is $161 \mathrm{mi}^{2}$ and is composed of sandy deposits with no surface-drainage features. The Cranberry and Bark Rivers are on the northwest side of the peninsula and generally flow from south to north. The Raspberry River drains the northern tip of the peninsula and also flows generally from south to north. The mouth of the Raspberry River is within the Red Cliff Reservation. The Sioux River has the largest surface-water-contributing basins of the five study-area basins, and flows from west to east on the east side of the peninsula. Whittlesey Creek is similar in drainage area to the Bark River and flows from west to east.

Bedrock underlying the peninsula includes the Precambrian Bayfield Group of the Keweenawan Supergroup (referred to hereafter as the Bayfield Group), which mainly consists of sandstone, siltstone, and locally abundant shale and conglomerate (Morey and Ojakangas, 1982; Mudrey and others, 1982; Cannon and others, 1996). The Bayfield Group is estimated to be as thick as 6,900 $\mathrm{ft}$ (Morey and Ojakangas, 1982), and crops out at several sites along the Lake Superior shoreline around the peninsula (Thwaites, 1911).

Bedrock is overlain by glacial, glaciolacustrine, and fluvial deposits, including sandy till of the Copper Falls Formation in the Bayfield Highlands and clayey glaciolacustrine deposits of the Miller Creek Formation at lower altitudes towards Lake Superior (fig. 4) (Goebel and others, 1983; Clayton, 1984). Unconsolidated deposits are several hundred feet thick in the Bayfield Highlands and generally thin toward Lake Superior. Where present, the Miller Creek Formation overlies the Bayfield Group and the Copper Falls Formation up to an altitude of about 1,100 ft. A major geologic feature that separates the clayey Miller Creek deposits in the lowland from the sandy Copper Falls Formation in the upland is a set of relict shorelines from glacial Lake Duluth at altitudes from about 900 to 1,100 ft (Clayton, 1984) (figs. 3 and 5). The relict shorelines are characterized by local wave-planed topography and about $3 \mathrm{ft}$ of nearshore sand overlying clayey Miller Creek deposits; however, Miller Creek deposits may have been entirely removed by wave action, exposing older Copper Falls deposits of sandy till or stream/shoreline sand and gravel (Clayton, 1984). The highest relict Duluth shoreline forms the divide between surface-water contributing and noncontributing areas (fig. $1 A$ ).

A geologic cross section in the vicinity of Whittlesey Creek illustrates the complexity of the texture and origin of the glacial deposits (Lenz and others, 2003) (fig. 6). Clay at the surface below 1,100 ft is the Miller Creek Formation. Sand and hardpan are associated with the Copper Falls Formation.

Several postglacial shorelines associated with falling levels of Lake Superior are evident on the 10-m digital elevation model (DEM) map of the Bayfield Peninsula (fig. 3) and the Whittlesey geologic cross section (fig. 6). The ancestral lakes were short-lived and existed from about 9,900 to 9,200 yr before the present (Clayton, 1984). At least seven shorelines have been identified in the area by Clayton (1984) and include the Duluth (1,100 ft), sub-Duluth (1,000-1,100 ft), Highbridge (980 ft), Moquah (930 ft), Washburn (880-890 ft), Manitou (about $750 \mathrm{ft}$ ), and Beaver Bay (650 ft). The shorelines are apparent on the geologic cross section of Whittlesey Creek where the slope steepens temporarily (fig. 6).

Soil types on the peninsula range from sandy to clayey and are related to underlying glacial deposits, slope, and vertical position in relation to glacial landforms (Hole, 1968) (fig. 7; table 1). The Cranberry River basin has the highest percentage of sandy soils, and the Whittlesey Creek basin has the highest percentage of clayey soils. Sandy soils are primarily in headwater areas. Soils developed in sand over clay (within a depth of $5 \mathrm{ft}$ ) reflect locations of the ancestral lake shorelines. Loamy soils underlain by clay are in the middle and lower parts of the basins; many feeder tributaries are cut through the loamy soils into the underlying clay. 


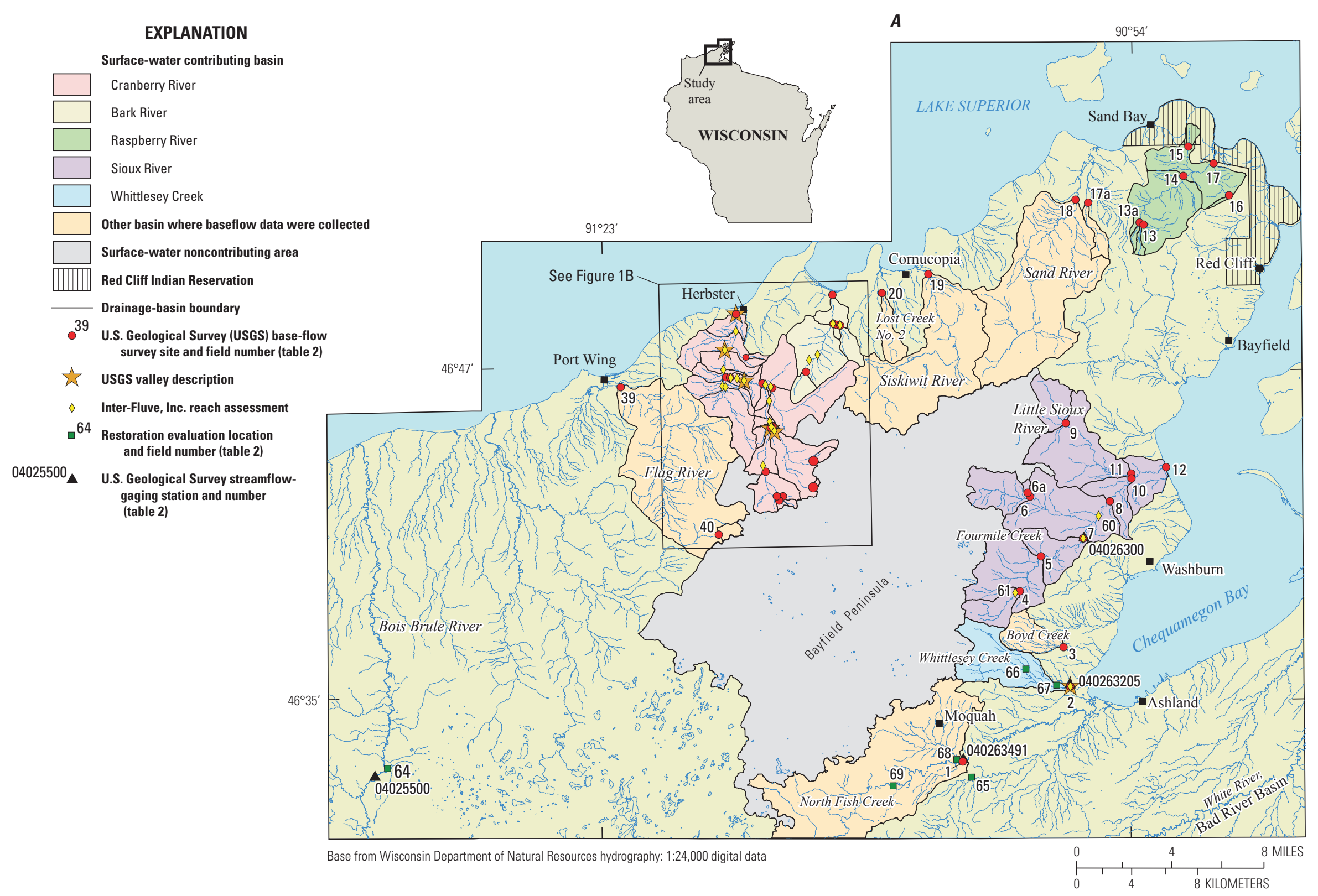

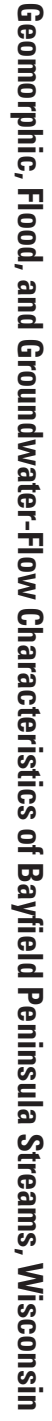

Figure 1. Locations of studied streams and sites in the Bayfield Peninsula, Wisconsin. $A$, entire study area, and $B$, Cranberry River and Bark River Basins. 


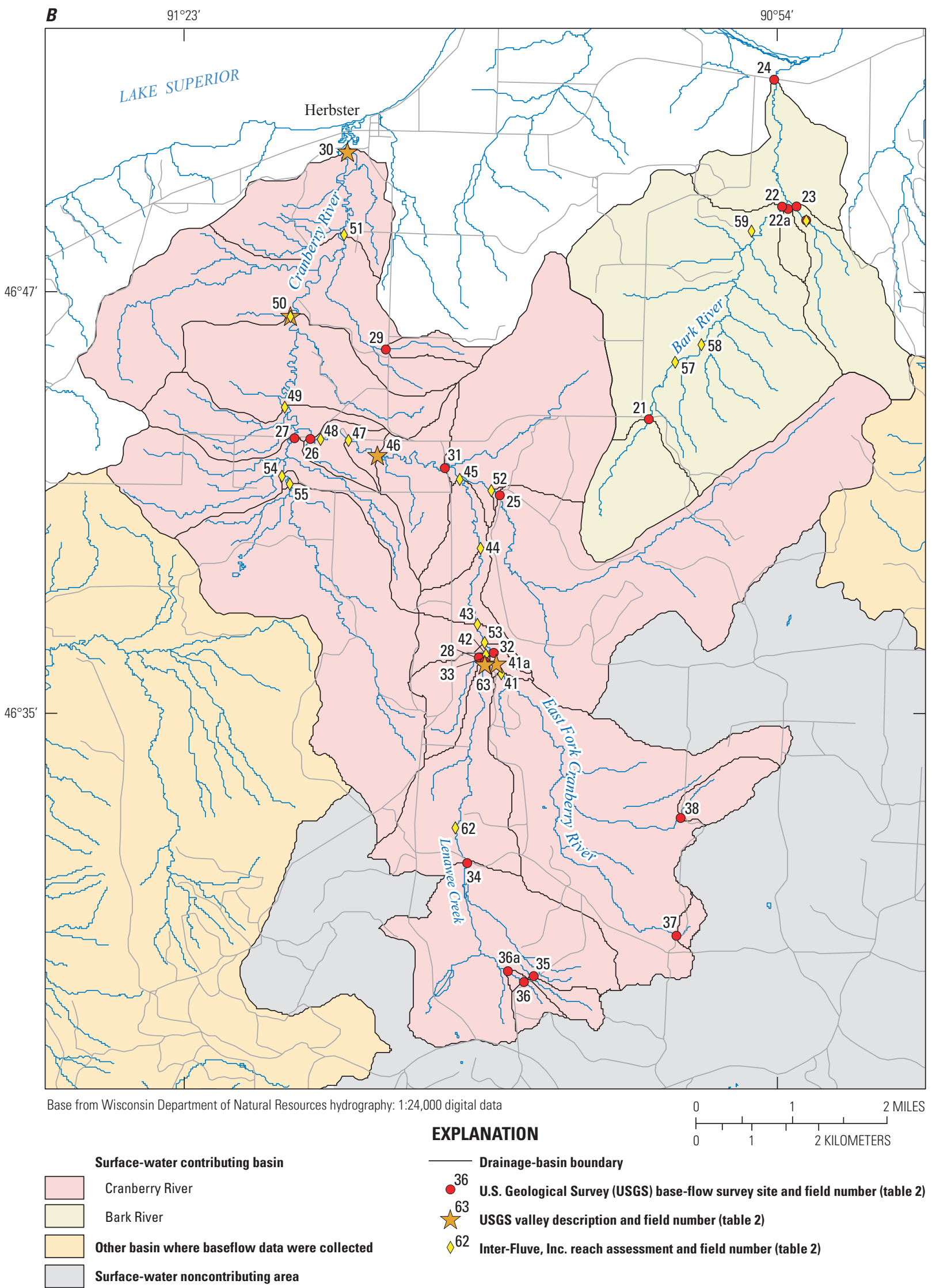

Figure 1. Locations of studied streams and sites in the Bayfield Peninsula, Wisconsin. $A$, entire study area, and $B$, Cranberry River and Bark River Basins.-Continued 


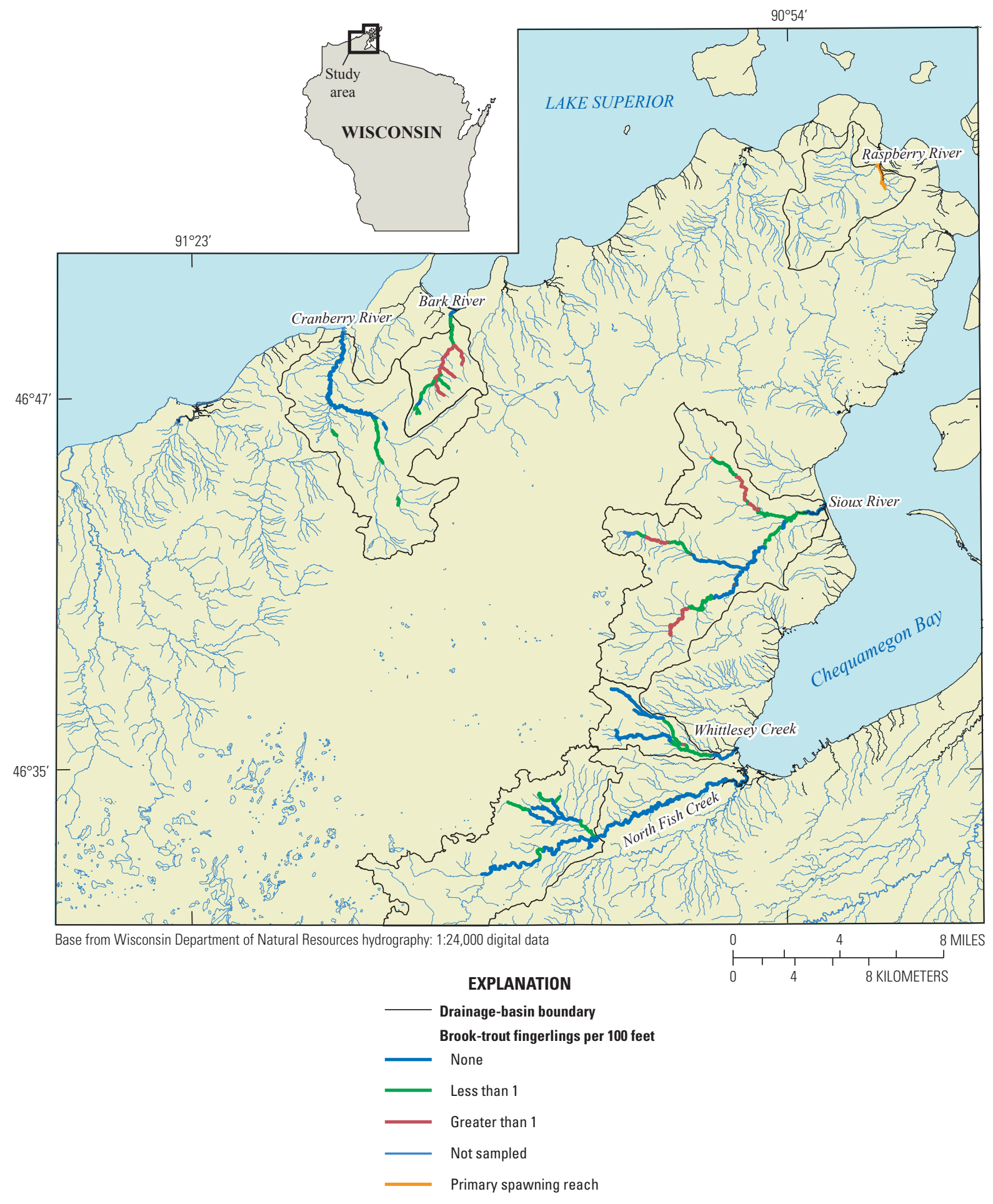

Figure 2. Distribution of brook-trout fingerlings in Bayfield Peninsula streams, 2004 (unpublished data, Wisconsin Department of Natural Resources, 2005). 


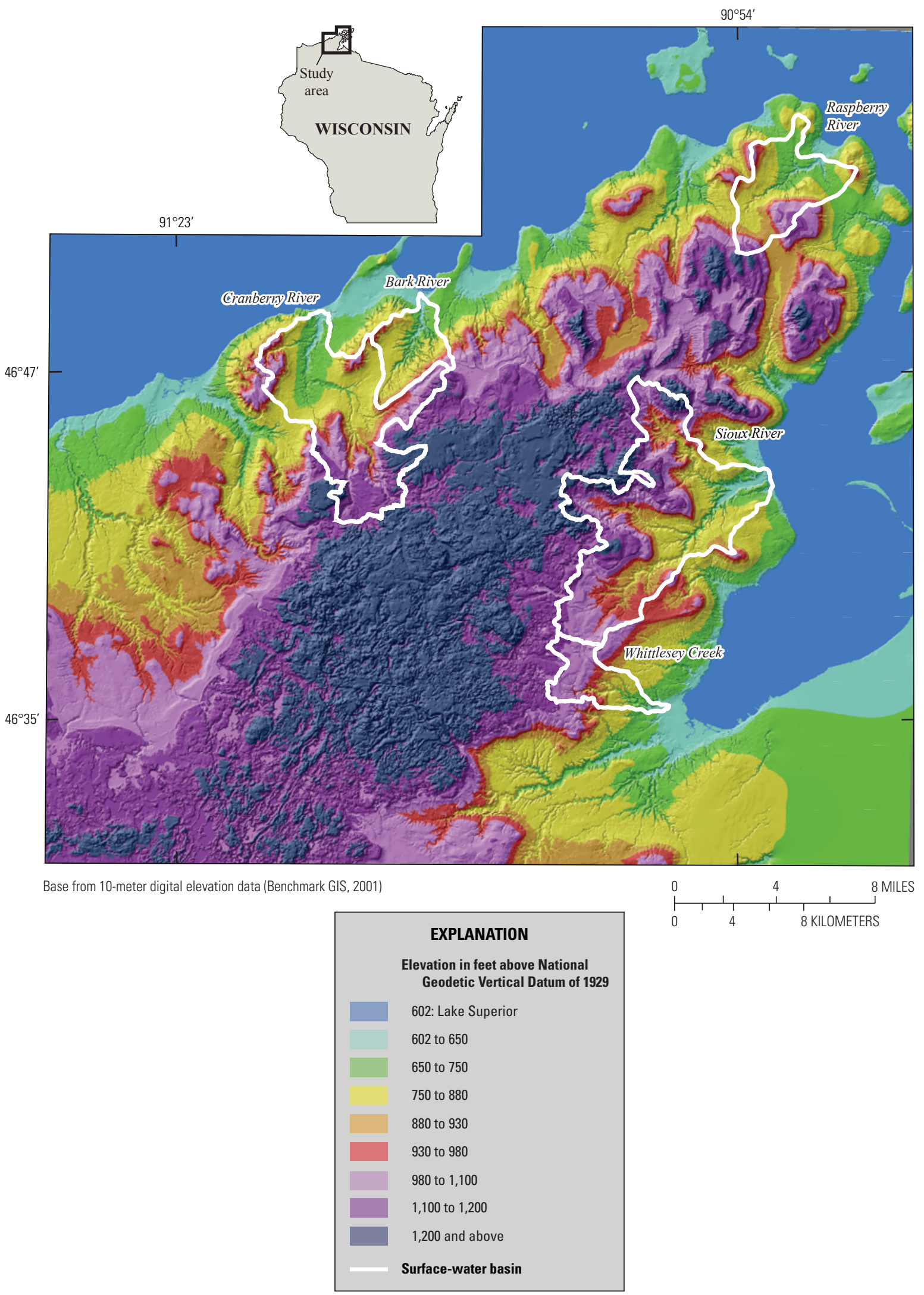

Figure 3. Digital elevation model of the Bayfield Peninsula, Wisconsin. Resolution of the data is 10 meters (Benchmark GIS, 2001). 
Table 1. Drainage-area, soil-texture, and land-cover characteristics of five streams, Bayfield Peninsula, Wisconsin.

$\left[\mathrm{mi}^{2}\right.$, square miles; <, greater than; na, data not available. Land-cover data from Reese and others (2002). Soils data from Natural Resources Conservation Service (2006). Noncontributing area has no surface-drainage features.]

\begin{tabular}{|c|c|c|c|c|c|c|}
\hline Characteristic & Cranberry River & Bark River & Raspberry River & Sioux River & Whittlesey Creek & $\begin{array}{c}\text { Surface-water noncon- } \\
\text { tributing area }\end{array}$ \\
\hline Drainage area $\left(\mathrm{mi}^{2}\right)$ & 31 & 8.2 & 14 & 44 & 7.4 & 161 \\
\hline \multicolumn{7}{|c|}{ Soil texture (percent) } \\
\hline Sand & 30 & 4.1 & 6.9 & 20 & 22 & 89 \\
\hline Sand over clay & 12 & 19 & 24 & 22 & 10 & $<0.1$ \\
\hline Loam over clay & 17 & 22 & 36 & 30.3 & 9.0 & 8.5 \\
\hline Loam over sand & $<0.1$ & 0.0 & 0.0 & 0.2 & 0.2 & 2.2 \\
\hline Loam over rock & 0.0 & 0.0 & 0.4 & $<0.1$ & 0.0 & 0.0 \\
\hline Clay & 24 & 28 & 12 & 4.7 & 36 & 0.0 \\
\hline Pits & $<0.1$ & 0.0 & 0.3 & $<0.1$ & 0.0 & $<0.1$ \\
\hline Water & 0.1 & 0.0 & $<0.1$ & $<0.1$ & 0.2 & 0.3 \\
\hline Undefined/ ravines & 6.0 & 14.3 & 10 & 9.3 & 11 & 0.0 \\
\hline \multicolumn{7}{|c|}{ 1992-93 Land cover (percent) } \\
\hline Agriculture & $<0.1$ & 0.0 & 0.0 & 0.6 & 2.3 & $<0.1$ \\
\hline Grassland & 7.9 & 7.0 & 13 & 12 & 26 & 3.0 \\
\hline Total forest & 87.6 & 88.2 & 84.9 & 82.7 & 64 & 85 \\
\hline Coniferous forest & 6.6 & 2.2 & 2.9 & 3.7 & 3.0 & 20 \\
\hline Deciduous forest & 69 & 74 & 59 & 63 & 48 & 52 \\
\hline Agriculture & 4.4 & 2.8 & 6.1 & 10 & 28.2 & na \\
\hline Pasture & 0.7 & 0.1 & 2.6 & 5.2 & 0.0 & na \\
\hline Forest & 91 & 97 & 91 & 84 & 60.2 & na \\
\hline Orchard & 0.0 & 0.0 & 0.0 & 0.1 & 0.0 & na \\
\hline Water & 0.1 & 0.0 & 0.0 & 0.2 & 0.0 & na \\
\hline Wetland & 3.0 & 0.0 & 0.0 & 0.2 & 11.6 & na \\
\hline Open land & 0.0 & 0.0 & 0.0 & 0.0 & 0.0 & na \\
\hline
\end{tabular}




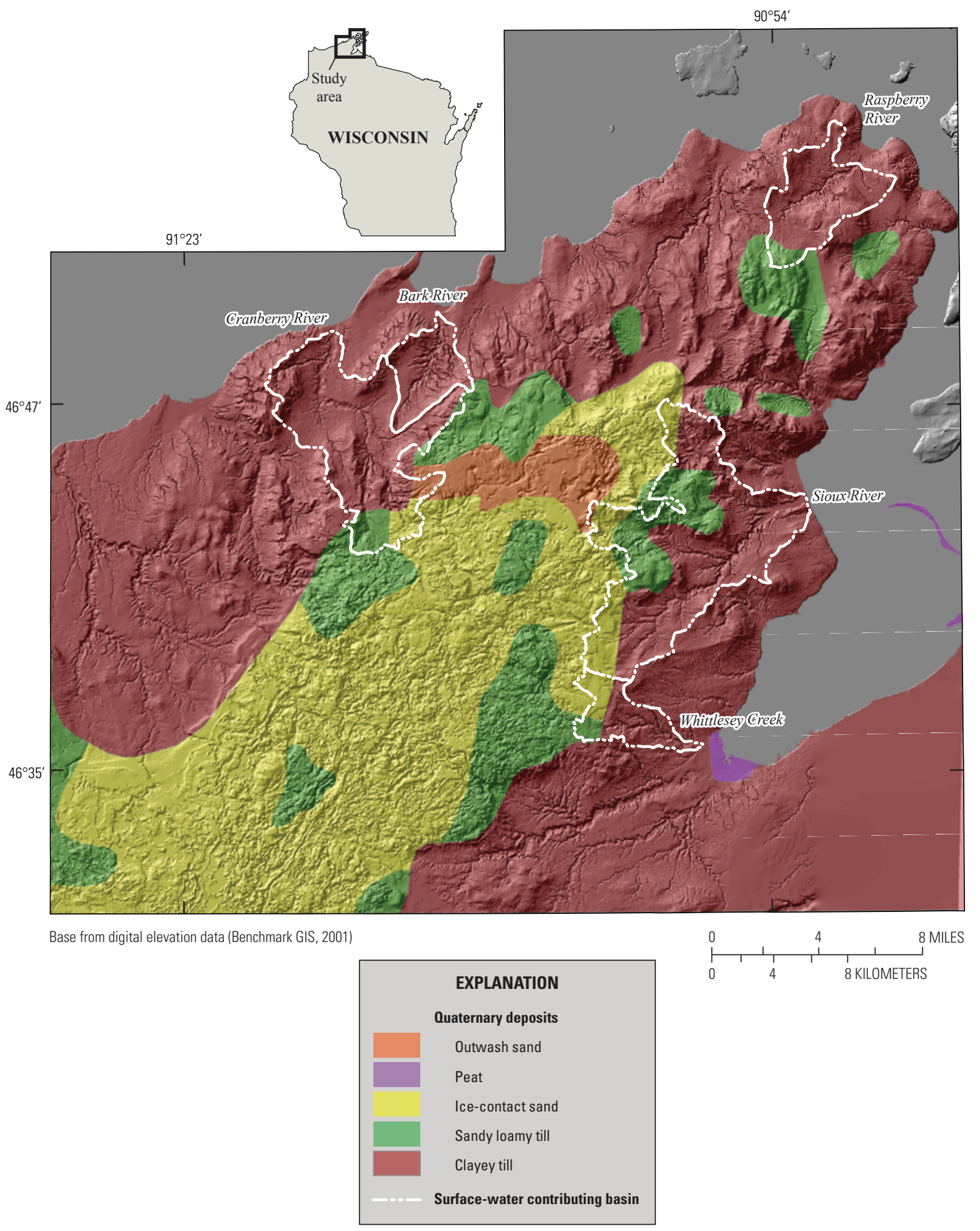

Figure 4. Quaternary geologic deposits for the Bayfield Peninsula, Wisconsin (Goebel and others, 1983). 


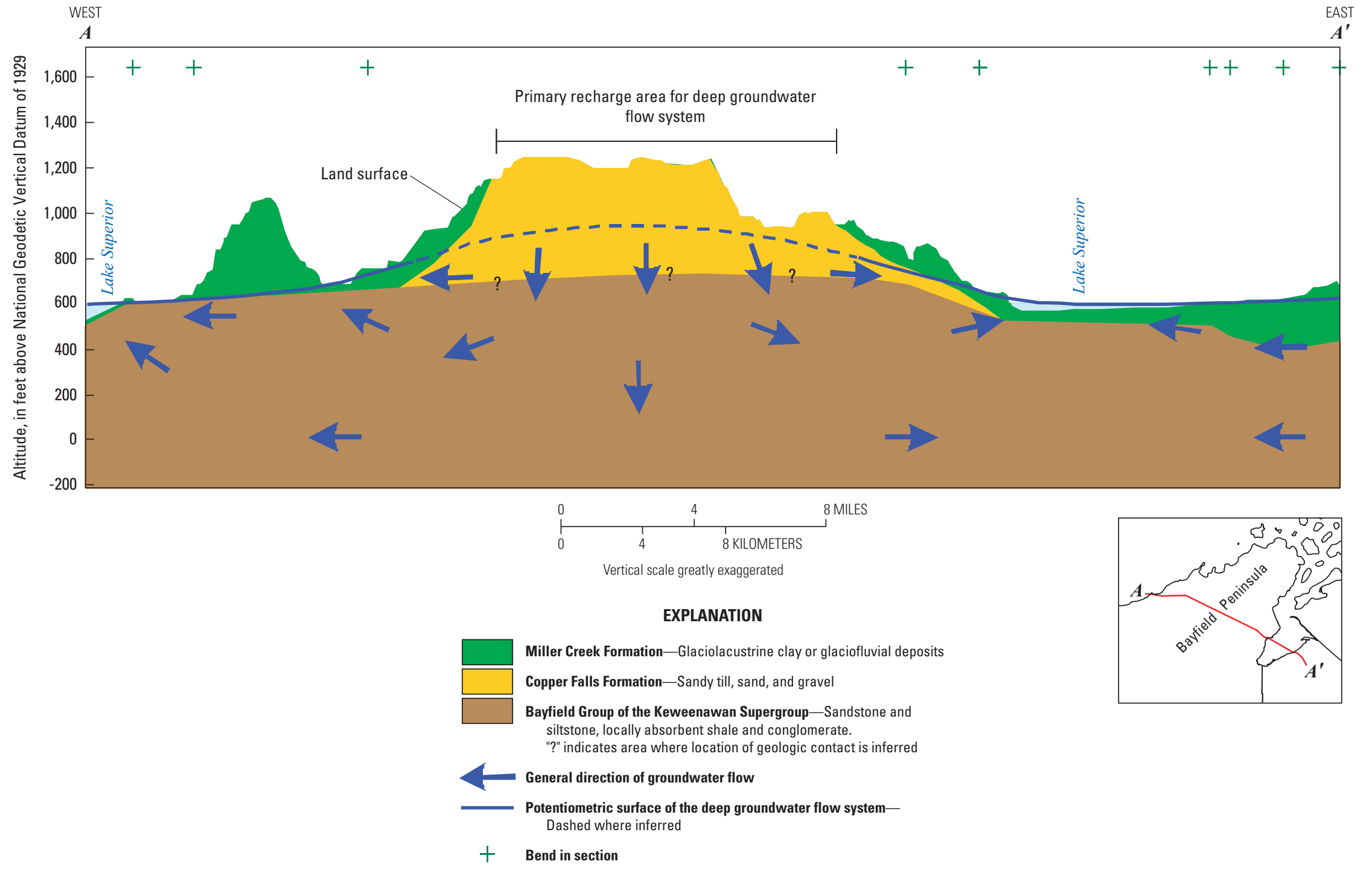

Figure 5. Schematic cross section showing generalized geology and conceptual model of the deep groundwater-flow system of the Bayfield Peninsula, Wisconsin. 


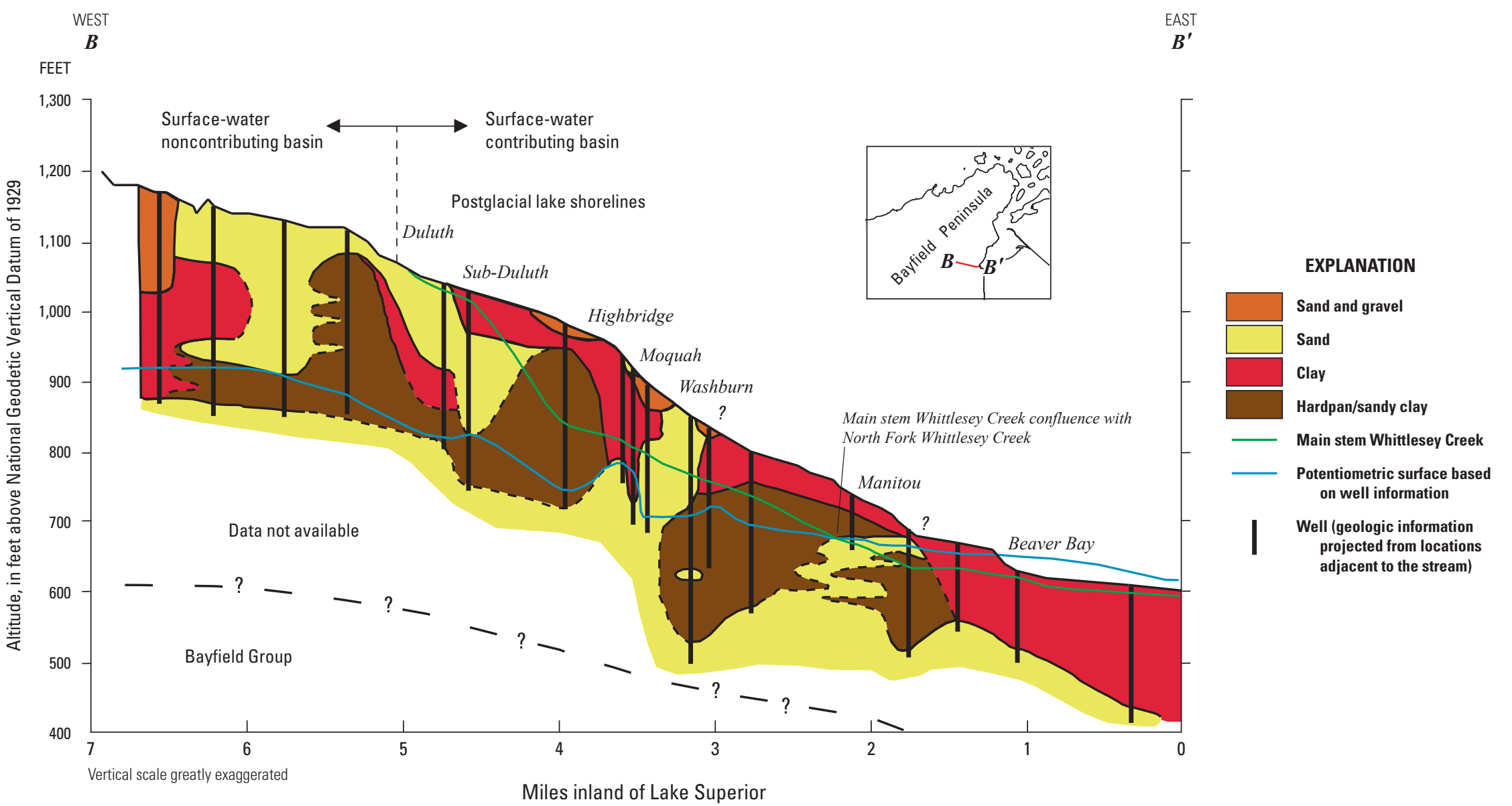

Figure 6. Geologic cross section through the southern part of the Whittlesey Creek Basin, Bayfield Peninsula, Wisconsin. 

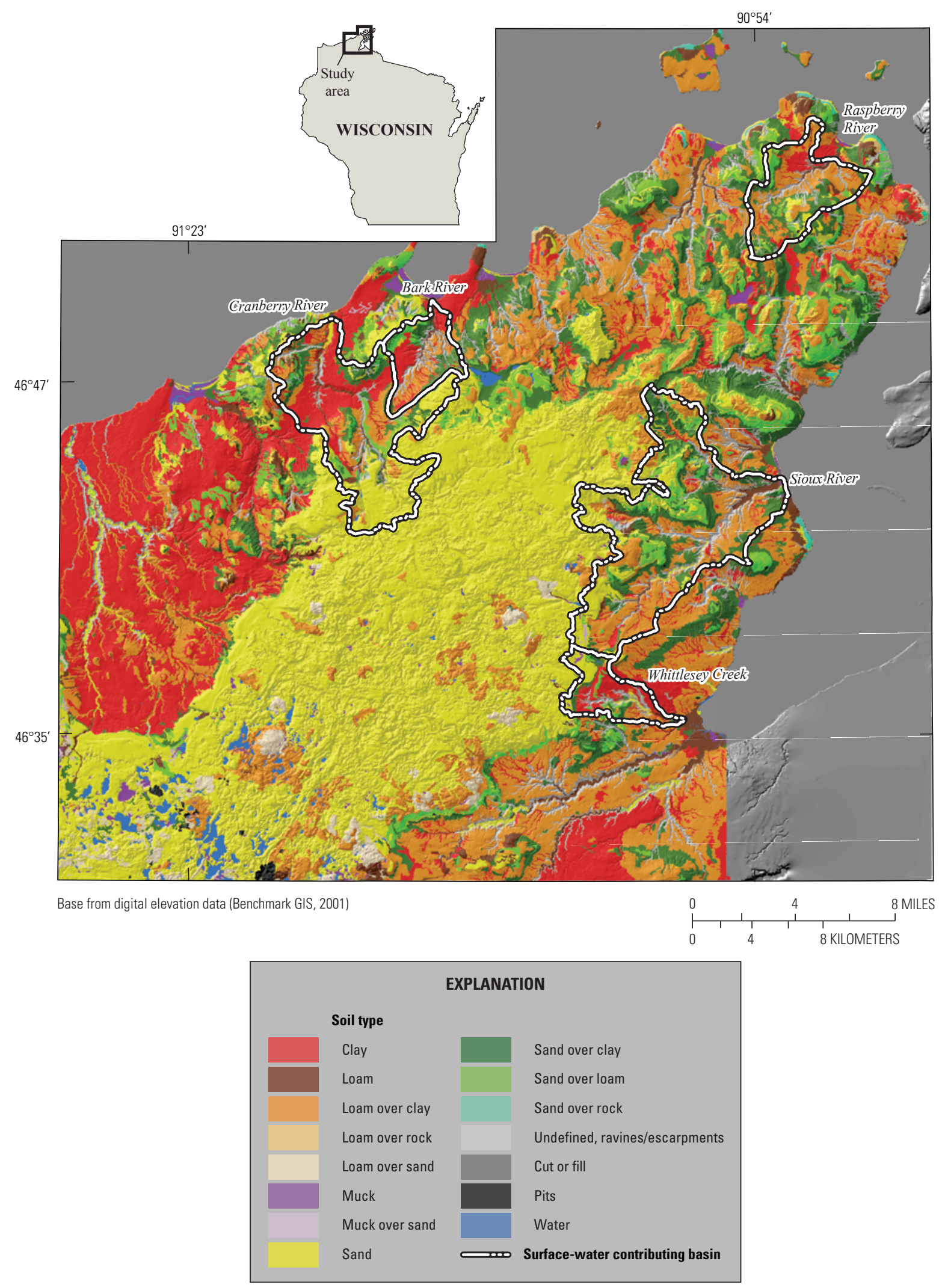

Figure 7. Soil types of the Bayfield Peninsula, Wisconsin (Natural Resources Conservation Service, 2006). 
The groundwater-flow system in the study area has deep and shallow components. The deep system, which includes thick deposits of sand and the upper part of the bedrock, underlies the entire study area, and groundwater moves primarily through the Copper Falls Formation and the upper part of the Bayfield Group (fig. 5). The deep system is unconfined at higher altitudes and confined at lower altitudes near Lake Superior, where the Miller Creek Formation overlies it. The deep system discharges to Lake Superior and deeply incised streams. The extent of the shallow system is difficult to delineate, but includes much of the area underlain by the Miller Creek Formation. The alternating layers of clay and sand in this area result in isolated areas of perched water that may be separated from the deep system by $100 \mathrm{ft}$ or more (Lenz and others, 2003). The shallow system receives less recharge than the deep system because the Miller Creek Formation is less permeable than the Copper Falls Formation. Some groundwater from the shallow system discharges to streams, and some likely recharges the deep system. The two systems merge where the deep system intersects the channels of gaining streams. The deep system and the nonperched part of the shallow system are included in simulations of groundwater flow, whereas perched flow is included in simulations of surface-water flow.

The regional climate is characterized by cold snowy winters, cool or moderately warm summers, and evenly distributed precipitation (Eichenlaub, 1979). Large local variations in average weather conditions are caused by lake effects because the peninsula is surrounded by Lake Superior. Average annual precipitation across the peninsula is $29-30$ in., with 16 in. of average annual evapotranspiration and 10-12 in. of runoff (Young and Skinner, 1974). Mean daily maximum air temperatures range from $22^{\circ} \mathrm{F}$ in January to $78^{\circ} \mathrm{F}$ in July (Eichenlaub, 1979).

The Bayfield Peninsula is mainly forested, with the drainage basins of the five streams having 64 to 88 percent forest cover in 1992-93 (Reese and others, 2002) (fig. 8, table 1). The Whittlesey Creek basin has the most agricultural land and grassland. Grassland is composed of pasture and abandoned farmland. For the middle of the peninsula in the surface-water noncontributing area, 84 percent is forested with 12 percent barren/shrubland. The barren/shrubland consists of a mix of recently logged areas and shrubland with pine barrens (extremely dry areas with small jack pine).

Old-growth forests on the Bayfield Peninsula were extensively logged and burned from about 1880 to 1900 . The Cranberry River, Bark River, Sioux River (including Fourmile Creek and the Little Sioux River), and Whittlesey Creek were used for log drives (no records were found for Raspberry River log drives). By the early 1900s, the entire peninsula had been logged and burned and agriculture activity was increasing (Wisconsin Department of Agriculture and Wisconsin
Geological and Natural History Survey, 1928). After peak agricultural activity in the late 1920s to early 1930s, the amount of forested land remained nearly constant, but much of the cropland was converted to pasture or grassland (table 1). In 1928 , over 90 percent of the trees had a diameter of less than 6 in. and were mainly poplar (Wisconsin Department of Agriculture and Wisconsin Geological and Natural History Survey, 1928). Ditches commonly were constructed in poorly drained clayey areas to speed drainage in spring and allow for earlier planting (Extension Service of College of Agriculture, University of Wisconsin-Madison, 1942).

\section{Flood History}

Long-term streamflow data, especially flood-series data, are useful for putting interpretations of geomorphic characteristics and processes into the proper hydrologic context. Four USGS streamflow-gaging stations in the vicinity of the Bayfield Peninsula have continuous streamflow data for various lengths of record. Nearby streamflow-gaging stations are on the Bois Brule River (USGS site identification number 04025500, record from 1944-2003), North Fish Creek (USGS site identification number 040263491; 1990-91, 1995-96, 2001-03), Whittlesey Creek (USGS site identification number 040263205, 1999-2003), and the Bad River (USGS site identification number 04027000; 1915-21, 1946, 1949-2003) (fig. $1 A$; the Bad River streamflow-gaging station is not shown on figure 1 but is $15 \mathrm{mi}$ southeast of Ashland). A USGS creststage gaging station is on the Sioux River (USGS site identification number 04026300, 1959-2003) (fig. 1A).

Annual flood peak data from the Sioux River crest-stage gaging station are probably the most useful in an assessment of historical geomorphic conditions for Bayfield streams because of the station's location in the middle of the peninsula; however, its record only extends back to 1959 (fig. 9). The Sioux River had large floods in 1960, 1964, 1985, and 2001. Historical newspaper accounts and anecdotal information from landowners indicate that a flood in June of 1946 from intense rainfall on North Fish Creek was the largest flood on record. The 1946 flood also was the largest flood on the Bad River (fig. 9). For the Bois Brule River, a flood in April 2001 was the largest flood on record, and a flood in 1944 was the second largest (fig. 9). Thus, it is possible that the April 2001 flood for Bayfield streams was the largest or second largest flood during the preceding 57 or more years. The 2001 flood was caused by a combination of snowmelt and rainfall. Streamflow records for Whittlesey Creek and North Fish Creek show that the 2001 flood was the largest flood recorded so far at these two stations, both of which have relatively short records (fig. 9). 

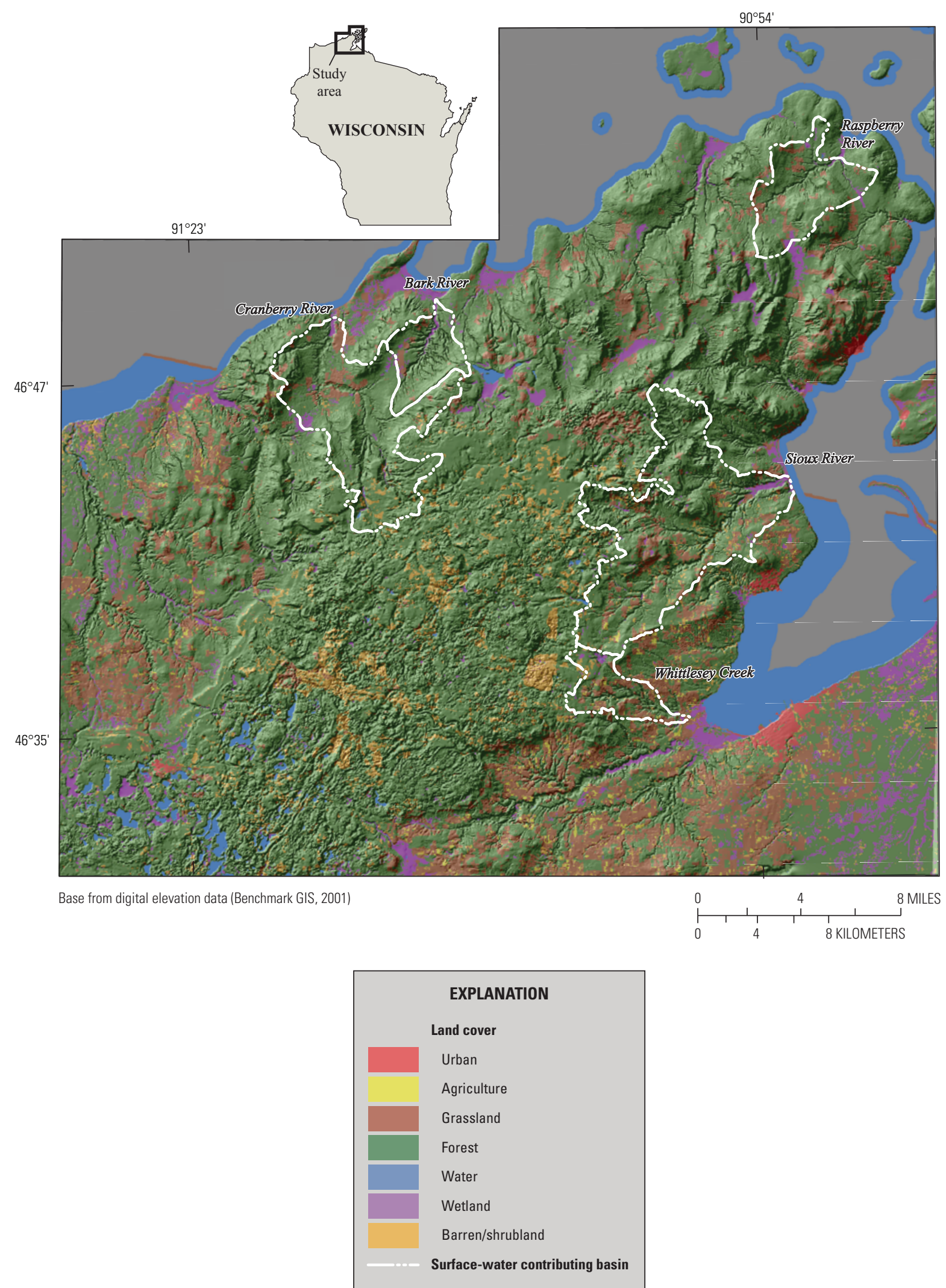

Figure 8. Land cover (1992-93) for the Bayfield Peninsula, Wisconsin (Reese and others, 2002). 

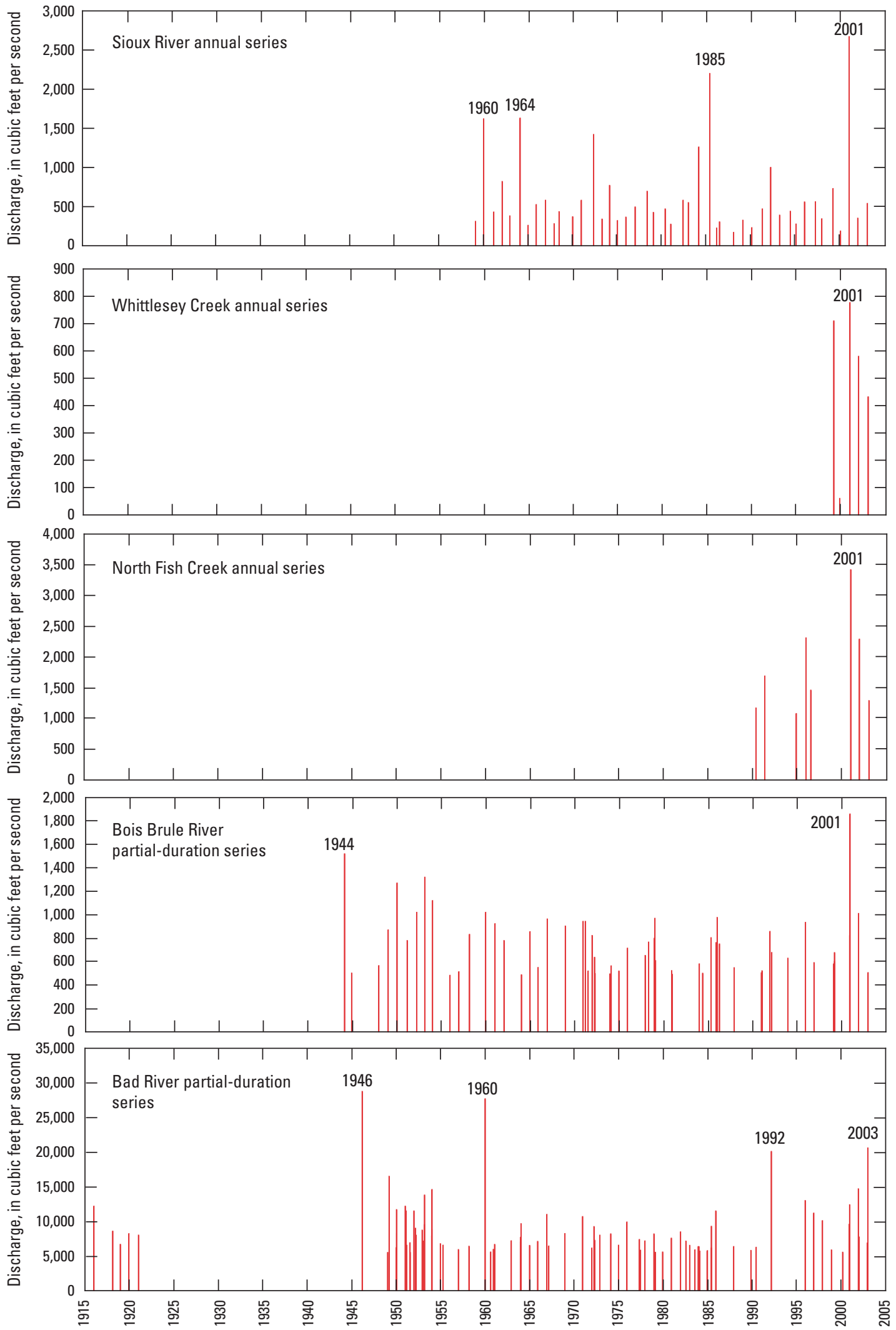

Figure 9. Flood peaks for the Sioux River, Whittlesey Creek, North Fish Creek, Bois Brule River, and Bad River flood-peak data from annual and partial-duration series. 


\section{Methods of Collecting Geomorphic, Flood, and Groundwater-Flow Data}

Understanding aquatic habitat requires a thorough characterization of the geomorphic, flood and groundwater conditions over multiple temporal and spatial scales. The characterization helped to describe the natural and historical and modern anthropogenic factors important in the Bayfield streams for affecting base flow, water temperature, sedimentation, and scour.

\section{Geomorphic Measurements and Data Collection}

Historical and present geomorphic conditions were assessed by use of historical documents and aerial photographs, longitudinal profiles, data from valley cross sections and cores, and video footage from a helicopter survey (table 2). Sites with erosion-control techniques used by the Red Clay Interagency Committee (RCIC) were revisited in 2003 to determine if the techniques were still controlling erosion.

\section{Historical Documents and Aerial Photographs}

Historical documents and aerial photographs were used to identify locations with bluff, terrace, or bank erosion, midchannel bar formation, or channel migration. Bluff and terrace erosion were distinguished from bank erosion because the higher altitudes of bluffs and terraces could have produced increased volumes of eroded sediment. Bank erosion is defined as stream cuts into flood-plain deposits with erosion heights of generally less than $10 \mathrm{ft}$. Terrace erosion is defined as stream cuts into terraces (remnant/ancient flood-plain surfaces), with heights of generally $20 \mathrm{ft}$ or less. Bluff erosion is defined as stream cuts into valley sides (usually glacial deposits). Erosion heights may be greater than $50 \mathrm{ft}$, depending on the degree of valley incision. Aerial-photograph interpretation was limited to main-stem channels because of resolution restraints and forest cover. USGS 7.5-minute topographic maps from the 1980s also were used to document channel migration.

Notes and maps from 1852 General Land Office (GLO) surveys were used to compare presettlement and 2002-2003 channel widths for the main stem of the Cranberry River. The GLO survey notes and maps contained information on vegetation, soils, and topography, as well as stream location and direction, width, depth, substrate, and flow before widespread logging and burning.

Data from a 1928 Land Economic Inventory (Wisconsin Department of Agriculture with the Wisconsin Geological and Natural History Survey, 1928) were used to characterize land cover during peak agricultural activity. Township maps were obtained from the Wisconsin State Historical Society Archives, scanned, georectified, and digitized. The Land Economic Inventory uses 25 categories for land cover, which were grouped for this study into 8 categories that most closely matched the 1992-93 land-cover categories (table 1).

\section{Data from Inter-Fluve, Inc.}

Inter-Fluve, Inc. and the USGS worked together on characterizing present and historical geomorphic conditions of the five Bayfield streams. Inter-Fluve, Inc. conducted reconnaissance surveys and collected channel-geometry and fish-passage data on all five streams in fall 2002 (fig. $1 A$ and $B)$ (Inter-Fluve, Inc. and Graber, 2003). Inter-Fluve, Inc.'s reconnaissance surveys included qualitative and quantitative data for channel vertical and lateral stability, bank erosion, sediment composition and characteristics, general salmonidhabitat quality, flood-plain characteristics, human influences, riparian vegetation and canopy characteristics, deposition, stream classification (Rosgen, 1996), and channel evolution (Schumm, 1977). Channel-geometry surveys included cross-section and longitudinal profiles, streambed-substrate characterization through pebble counts (Wolman, 1954), and channel-roughness estimates. Inter-Fluve, Inc. used these data to estimate bankfull flow, channel shear stress, and stream power. Fish-passage data at culvert and bridge crossings included slope, culvert and bridge dimensions, velocity at low flow, characteristics of upstream and downstream approaches, and tailwater conditions.

Inter-Fluve, Inc. calculated average channel shear stress for bankfull conditions from channel cross-section and reach slope data. Average channel shear stress is the force exerted on a channel bottom and is calculated by the following equation:

$$
\tau=\gamma R S
$$

where

$$
\begin{array}{ll}
\tau & \text { is shear stress, in lbs/ } \mathrm{ft}^{2}, \\
\gamma & \text { is the specific weight of water }\left(62 \mathrm{lbs} / \mathrm{ft}^{3}\right), \\
R & \text { is the hydraulic radius at bankfull stage, in } \\
& \mathrm{ft} \text { (which is equal to the channel cross- } \\
& \text { sectional area divided by the channel } \\
\text { perimeter), and }
\end{array}
$$

Thus, the slope and the shape and size of the channel determine shear stress. High shear stress indicates a greater potential for erosion of particles along channel bed and banks. As slope or hydraulic radius increases, the potential for erosion increases.

\section{Longitudinal Profiles}

Longitudinal profiles were constructed for the five streams. A longitudinal profile represents the changes in altitude of a stream along its length, from the mouth to its headwaters. Stream lengths were measured with a map wheel between contour lines on USGS 7.5-minute topographic maps 
Table 2. Sites sampled in 2002-2003 as part of the study of the geomorphic, flood, and groundwater-flow characteristics of Bayfield Peninsula streams, Wisconsin.

[USGS, U.S. Geological Survey; mi², square miles; na, data not available; Wis., Wisconsin; Rd., road; Cty., County; Hwy., highway; Trib., tributary; DNR, Wisconsin Department of Natural Resources. Purpose column abbreviations: B, USGS base-flow survey; I, Inter-Fluve, Inc. reach assessment; V, USGS valley transect; C, USGS coring; and E, erosion-control evaluation.]

\begin{tabular}{|c|c|c|c|c|c|c|}
\hline $\begin{array}{l}\text { USGS } \\
\text { field } \\
\text { number }\end{array}$ & $\begin{array}{l}\text { USGS station } \\
\text { number }\end{array}$ & $\begin{array}{l}\text { Inter-Fluve, } \\
\text { Inc. station } \\
\text { code }\end{array}$ & Stream name & Purpose & Latitude/longitude & $\begin{array}{l}\text { Drainage } \\
\text { area }\left(\mathrm{mi}^{2}\right)\end{array}$ \\
\hline 1 & 040263491 & na & North Fish Creek near Moquah, Wis. & $\mathrm{B}$ & $46^{\circ} 32^{\prime} 56^{\prime \prime}, 91^{\circ} 03^{\prime} 43^{\prime \prime}$ & 38 \\
\hline 2 & 040263205 & WHGAUGE & Whittlesey Creek near Ashland, Wis. & BIVC & $46^{\circ} 35^{\prime} 40^{\prime \prime}, 90^{\circ} 57^{\prime} 47^{\prime \prime}$ & 7.4 \\
\hline 3 & 04026318 & na & $\begin{array}{l}\text { Boyd Creek at Ondassagon Rd. near Ashland, } \\
\text { Wis. }\end{array}$ & B & $46^{\circ} 37^{\prime} 14^{\prime \prime}, 90^{\circ} 58^{\prime} 10^{\prime \prime}$ & 3.1 \\
\hline 5 & 04026295 & na & $\begin{array}{l}\text { Sioux River at Church Corner Rd. near } \\
\text { Washburn, Wis. }\end{array}$ & $\mathrm{B}$ & $46^{\circ} 40^{\prime} 35^{\prime \prime}, 90^{\circ} 59^{\prime} 22^{\prime \prime}$ & 10 \\
\hline 6 & 04026305 & na & $\begin{array}{l}\text { Fourmile Creek at County C near Washburn, } \\
\text { Wis. }\end{array}$ & $\mathrm{B}$ & $46^{\circ} 42^{\prime} 50^{\prime \prime}, 91^{\circ} 00^{\prime} 02^{\prime \prime}$ & 4.0 \\
\hline 8 & 04026308 & na & $\begin{array}{l}\text { Sioux River at Big Rock Rd. near Washburn, } \\
\text { Wis. }\end{array}$ & B & $46^{\circ} 42^{\prime} 37^{\prime \prime}, 90^{\circ} 55^{\prime} 33^{\prime \prime}$ & 27 \\
\hline 9 & 04026311 & na & $\begin{array}{l}\text { Little Sioux River at Little Sioux Rd. near } \\
\text { Washburn, Wis. }\end{array}$ & $\mathrm{B}$ & $46^{\circ} 45^{\prime} 37^{\prime \prime}, 90^{\circ} 58^{\prime} 02^{\prime \prime}$ & 2.9 \\
\hline 10 & 04026309 & na & $\begin{array}{l}\text { Sioux River at Friendly Valley Rd. near } \\
\text { Washburn, Wis. }\end{array}$ & B & $46^{\circ} 43^{\prime} 32^{\prime \prime}, 90^{\circ} 54^{\prime} 27^{\prime \prime}$ & 29 \\
\hline 11 & 04026315 & na & Little Sioux River near Washburn, Wis. & $\mathrm{B}$ & $46^{\circ} 43^{\prime} 36^{\prime \prime}, 90^{\circ} 54^{\prime} 27^{\prime \prime}$ & 12 \\
\hline 12 & 04026316 & na & Sioux River near Washburn, Wis. & $\mathrm{B}$ & $46^{\circ} 44^{\prime} 03^{\prime \prime}, 90^{\circ} 52^{\prime} 35^{\prime \prime}$ & 44 \\
\hline 13 & 04026207 & na & $\begin{array}{l}\text { Tributary Raspberry River at Hwy. } 13 \text { near } \\
\text { Sand Bay, Wis. }\end{array}$ & B & $46^{\circ} 53^{\prime} 06^{\prime \prime}, 90^{\circ} 53^{\prime} 51^{\prime \prime}$ & 0.31 \\
\hline 17 & 04026215 & na & Raspberry River near Sand Bay, Wis. & $\mathrm{B}$ & $46^{\circ} 55^{\prime} 24^{\prime \prime}, 90^{\circ} 49^{\prime} 51^{\prime \prime}$ & 14 \\
\hline $17 \mathrm{a}$ & 04026200 & na & Sand River tributary near Red Cliff, Wis. & B & $46^{\circ} 53^{\prime} 53^{\prime \prime}, 90^{\circ} 56^{\prime} 47^{\prime \prime}$ & 1.1 \\
\hline 18 & 04026190 & na & Sand River near Red Cliff, Wis. & B & $46^{\circ} 54^{\prime} 0^{\prime \prime}, 90^{\circ} 57^{\prime} 20^{\prime \prime}$ & 27 \\
\hline 19 & 04026160 & na & Siskiwit River at Cornucopia, Wis. & $\mathrm{B}$ & $46^{\circ} 51^{\prime} 17^{\prime \prime}, 91^{\circ} 5^{\prime} 29^{\prime \prime}$ & 22 \\
\hline 20 & 04026150 & na & Lost Creek No. 2 near Cornucopia, Wis. & B & $46^{\circ} 50^{\prime} 33^{\prime \prime}, 91^{\circ} 8^{\prime} 4^{\prime \prime}$ & 1.9 \\
\hline 21 & 04026135 & na & Bark River at Bark River Rd. near Herbster, Wis. & $\mathrm{B}$ & $46^{\circ} 47^{\prime} 35^{\prime \prime}, 91^{\circ} 12^{\prime} 18^{\prime \prime}$ & 0.92 \\
\hline 22 & 04026137 & na & $\begin{array}{l}\text { Bark River near Bark River Rd. near Herbster, } \\
\text { Wis. }\end{array}$ & B & $46^{\circ} 49^{\prime} 18^{\prime \prime}, 91^{\circ} 10^{\prime} 42^{\prime \prime}$ & 5.9 \\
\hline $22 \mathrm{a}$ & 04026138 & na & $\begin{array}{l}\text { Tributary Bark River near Bark River Rd. near } \\
\text { Herbster, Wis. }\end{array}$ & $\mathrm{B}$ & $46^{\circ} 49^{\prime} 21^{\prime \prime}, 91^{\circ} 10^{\prime} 36^{\prime \prime}$ & 0.14 \\
\hline 23 & 04026139 & BTRIB & $\begin{array}{l}\text { East Branch Bark River near Bark River Rd. } \\
\text { near Herbster, Wis. }\end{array}$ & $\mathrm{BI}$ & $46^{\circ} 49^{\prime} 25^{\prime \prime}, 91^{\circ} 10^{\prime} 36^{\prime \prime}$ & 1.1 \\
\hline 24 & 04026140 & na & Bark River near Cornucopia, Wis. (at Hwy. 13) & $\mathrm{B}$ & $46^{\circ} 50^{\prime} 27^{\prime \prime}, 91^{\circ} 10^{\prime} 49^{\prime \prime}$ & 8.2 \\
\hline
\end{tabular}


Table 2. Sites sampled in 2002-2003 as part of the study of the geomorphic, flood, and groundwater-flow characteristics of Bayfield Peninsula streams, Wisconsin.-Continued

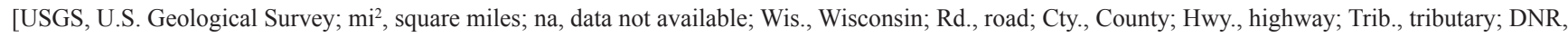
Wisconsin Department of Natural Resources. Purpose column abbreviations: B, USGS base-flow survey; I, Inter-Fluve, Inc. reach assessment; V, USGS valley transect; C, USGS coring; and E, erosion-control evaluation.]

\begin{tabular}{|c|c|c|c|c|c|c|}
\hline $\begin{array}{l}\text { USGS } \\
\text { field } \\
\text { number }\end{array}$ & $\begin{array}{l}\text { USGS station } \\
\text { number }\end{array}$ & $\begin{array}{l}\text { Inter-Fluve, } \\
\text { Inc. station } \\
\text { code }\end{array}$ & Stream name & Purpose & Latitude/longitude & $\begin{array}{l}\text { Drainage } \\
\text { area }\left(\mathrm{mi}^{2}\right)\end{array}$ \\
\hline 25 & 04026127 & na & $\begin{array}{l}\text { East Branch East Fork Cranberry River near } \\
\text { Herbster, Wis. }\end{array}$ & $\mathrm{B}$ & $46^{\circ} 46^{\prime} 53^{\prime \prime}, 91^{\circ} 14^{\prime} 6^{\prime \prime}$ & 5.0 \\
\hline 26 & 04026130 & na & $\begin{array}{l}\text { East Fork Cranberry River at Touve Rd. near } \\
\text { Herbster, Wis. }\end{array}$ & $\mathrm{B}$ & $46^{\circ} 47^{\prime} 20^{\prime \prime}, 91^{\circ} 16^{\prime} 25^{\prime \prime}$ & 19 \\
\hline 28 & 040261261 & na & $\begin{array}{l}\text { Tributary Lenawee Cr. near Lenawee Rd. near } \\
\text { Herbster, Wis. }\end{array}$ & $\mathrm{B}$ & $46^{\circ} 45^{\prime} 32^{\prime \prime}, 91^{\circ} 14^{\prime} 15^{\prime \prime}$ & 0.40 \\
\hline 29 & 040261315 & na & $\begin{array}{l}\text { Trib. Cranberry River at Lenawee Rd. near } \\
\text { Herbster, Wis. }\end{array}$ & $\mathrm{B}$ & $46^{\circ} 48^{\prime} 7^{\prime \prime}, 91^{\circ} 15^{\prime} 31^{\prime \prime}$ & 0.18 \\
\hline 32 & 040261248 & na & $\begin{array}{l}\text { East Fork Cranberry River near Lenawee Rd } \\
\text { near Herbster, Wis. }\end{array}$ & $\mathrm{B}$ & $46^{\circ} 45^{\prime} 34^{\prime \prime}, 91^{\circ} 14^{\prime} 8^{\prime \prime}$ & 4.5 \\
\hline 33 & 04026126 & na & $\begin{array}{l}\text { Lenawee Creek near Lenawee Rd. near Herbster, } \\
\text { Wis. }\end{array}$ & $\mathrm{B}$ & $46^{\circ} 45^{\prime} 31^{\prime \prime}, 91^{\circ} 14^{\prime} 15^{\prime \prime}$ & 4.2 \\
\hline 34 & 040261258 & na & $\begin{array}{l}\text { Lenawee Creek at Seven Mile Rd. near Herbster, } \\
\text { Wis. }\end{array}$ & $\mathrm{B}$ & $46^{\circ} 43^{\prime} 48^{\prime \prime}, 91^{\circ} 14^{\prime} 24^{\prime \prime}$ & 2.7 \\
\hline 35 & 04026125 & na & $\begin{array}{l}\text { Lenawee Cr. Trib. \#2 at Sand Trap Rd near } \\
\text { Herbster, Wis. }\end{array}$ & $\mathrm{B}$ & $46^{\circ} 42^{\prime} 51^{\prime \prime}, 91^{\circ} 13^{\prime} 37^{\prime \prime}$ & 0.17 \\
\hline 36 & 040261254 & na & $\begin{array}{l}\text { Lenawee Creek Trib. at Sand Trap Rd near } \\
\text { Herbster, Wis. }\end{array}$ & $\mathrm{B}$ & $46^{\circ} 42^{\prime} 47^{\prime \prime}, 91^{\circ} 13^{\prime} 43^{\prime \prime}$ & 0.14 \\
\hline 39 & 04026120 & na & Flag River at Port Wing, Wis. & $\mathrm{B}$ & $46^{\circ} 46^{\prime} 58^{\prime \prime}, 91^{\circ} 22^{\prime} 25^{\prime \prime}$ & 28 \\
\hline 40 & 04026117 & na & Flag River near Port Wing, Wis. & $\mathrm{B}$ & $46^{\circ} 41^{\prime} 25^{\prime \prime}, 91^{\circ} 16^{\prime} 59^{\prime \prime}$ & 0.57 \\
\hline 41 & na & CR01 & $\begin{array}{l}\text { East Fork Cranberry River upstream of Lenawee } \\
\text { Creek }\end{array}$ & I & $46^{\circ} 45^{\prime} 23^{\prime \prime}, 91^{\circ} 14^{\prime} 01^{\prime \prime}$ & 4.5 \\
\hline $41 \mathrm{a}$ & na & na & $\begin{array}{l}\text { East Fork Cranberry River upstream of Lenawee } \\
\text { Creek }\end{array}$ & $\mathrm{VC}$ & $46^{\circ} 45.471^{\prime}, 91^{\circ} 14.097^{\prime}$ & 4.4 \\
\hline 42 & na & CR02 & $\begin{array}{l}\text { East Fork Cranberry River downstream of } \\
\text { Lenawee Creek }\end{array}$ & I & $46^{\circ} 45^{\prime} 39^{\prime \prime}, 91^{\circ} 14^{\prime} 15^{\prime \prime}$ & 9.1 \\
\hline 43 & na & CR03 & $\begin{array}{l}\text { East Fork Cranberry River near Pearson and } \\
\text { Issakson property }\end{array}$ & I & $46^{\circ} 45^{\prime} 48^{\prime \prime}, 91^{\circ} 14^{\prime} 20^{\prime \prime}$ & 9.4 \\
\hline 44 & na & CR04 & East Fork Cranberry River near Koehn property & I & $46^{\circ} 46^{\prime} 28^{\prime \prime}, 91^{\circ} 14^{\prime} 18^{\prime \prime}$ & 9.7 \\
\hline 45 & na & CR05 & East Fork Cranberry River near Lourma property & I & $46^{\circ} 47^{\prime} 02^{\prime \prime}, 91^{\circ} 14^{\prime} 35^{\prime \prime}$ & 10 \\
\hline 46 & na & CR06 & East Fork Cranberry River at Lenawee Road & IVC & $46^{\circ} 47^{\prime} 12^{\prime \prime}, 91^{\circ} 15^{\prime} 36^{\prime \prime}$ & 18 \\
\hline
\end{tabular}


Table 2. Sites sampled in 2002-2003 as part of the study of the geomorphic, flood, and groundwater-flow characteristics of Bayfield Peninsula streams, Wisconsin.-Continued

[USGS, U.S. Geological Survey; mi² $^{2}$ square miles; na, data not available; Wis., Wisconsin; Rd., road; Cty., County; Hwy., highway; Trib., tributary; DNR, Wisconsin Department of Natural Resources. Purpose column abbreviations: B, USGS base-flow survey; I, Inter-Fluve, Inc. reach assessment; V, USGS valley transect; C, USGS coring; and E, erosion-control evaluation.]

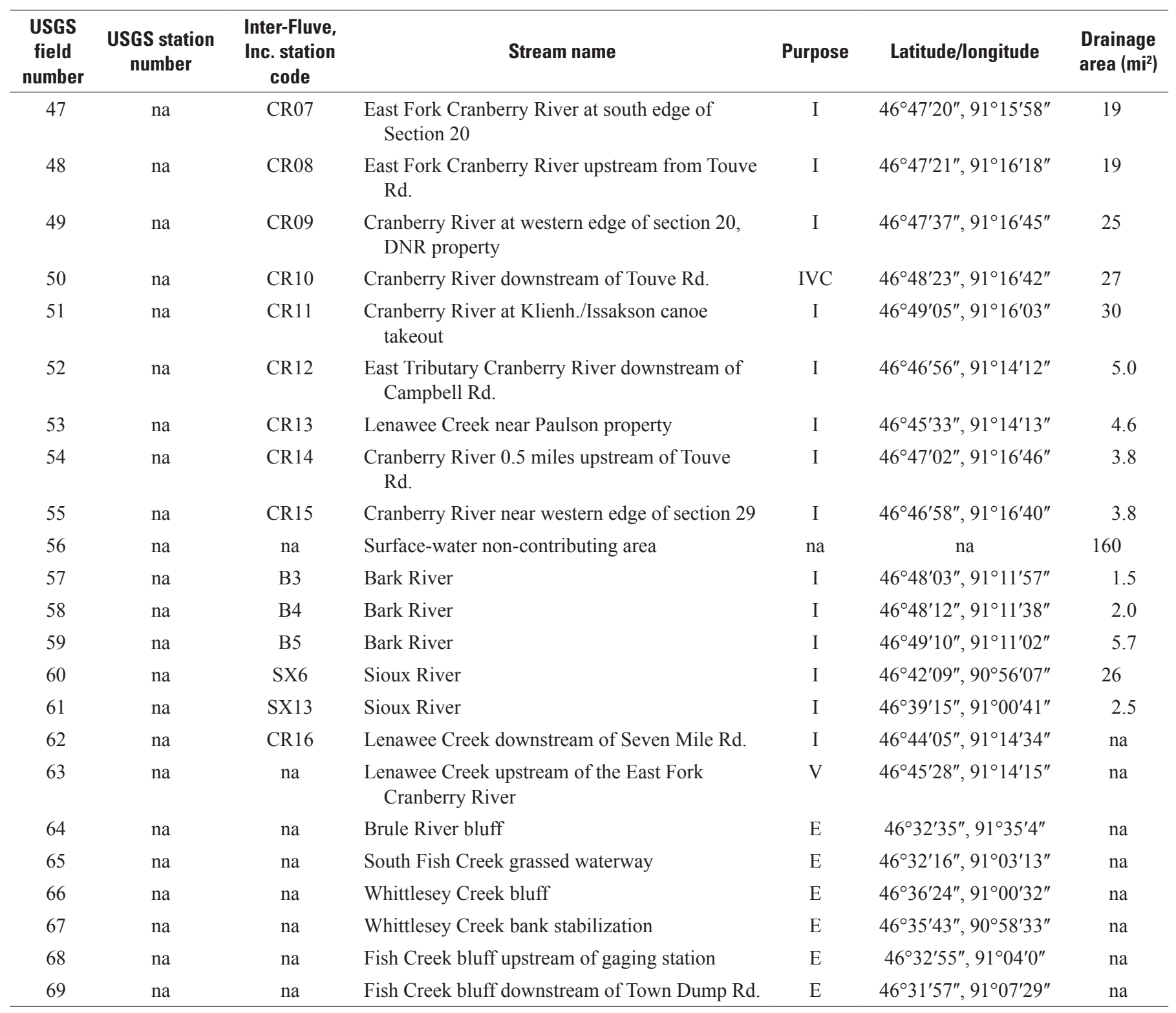


published between 1964 and 1984. Longitudinal profiles were used to identify large-scale slope changes that are usually related to geologic features or channel location within the drainage network. Slope may have changed in specific reaches after the maps were published.

\section{Helicopter Video Interpretation}

Windway Capital Corporation conducted a low-altitude video survey with a helicopter of four of the five studied streams in 2003. The video camera was linked with a global positioning system (GPS). The Cranberry River, Whittlesey Creek, Sioux River, and the Sand River were videotaped on April 30 and May 1, 2003. No helicopter video footage was shot of the Raspberry River or the East Fork Cranberry River upstream of the confluence with the East Branch of the East Fork Cranberry River. The Bark River was videotaped on November 14, 2003. The main stems of the Sioux River, Fourmile Creek, and the Little Sioux River were videotaped. Locations of bank, bluff, and terrace erosion, large depositional bars, log jams, boulder bars, and beaver activity were tabulated from the videos.

\section{Valley Cross-Section Surveying and Coring}

Field data for valley cross sections and cores were collected by the USGS from fall 2002 through fall 2003. These data were used to determine rates of incision and sedimentation for five sites along the Cranberry River and one site near the mouth of Whittlesey Creek (figs. $1 A$ and $B$ ). Results were compared with core data from North Fish Creek (Fitzpatrick, 1998). A GPS was used to verify the location of each cross section. Semipermanent benchmarks consisting of 4-ft concrete reinforcing bars pounded into the ground or lag bolts in nearby tree trunks were established at each cross section.

The thickness, texture, chemistry, and age of sediment in the flood plain and channel were examined by sediment coring and sampling with a 1-in. diameter hand-held soil probe and a Geoprobe. The hand-held soil probe was useful for quick exploratory and reconnaissance coring and for coring in

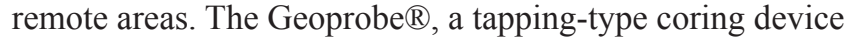
mounted on a four-wheel all-terrain vehicle, was used to collect deeper cores from accessible flood-plain areas.

The U.S. Department of Agriculture textural triangle and color chart (Munsell Color, 1975; U.S. Department of Agriculture, Soil Conservation Service, Soil Survey Staff, 1951) were used in the field to classify all cores for texture and color. Grading of texture was done by one person by rubbing soil between the fingers and using techniques described in Milfred and others (1967). Core-recovery ratios (the retrieved length of sample in the corer compared to the depth interval sampled) were recorded. If present in the cores, wood pieces were frozen and archived for possible radiocarbon-age determinations in the future if funding becomes available.
Buried soils are commonly found in flood-plain deposits and can be good indicators of flood-plain surface stability. Buried soils are developed in older flood-plain surfaces (Birkland, 1984; Retallick, 1985). In general, modern flood-plain soils are usually poorly developed because of the possibility for a fast rate of burial, high water table, and anthropogenic disturbance. Many buried flood-plain surfaces have the beginnings of an A horizon or only a thin layer of organic matter and remnants of decaying vegetation. The A horizon is a dark zone at the surface of the soil caused by accumulation of decomposing organic matter. The buried flood-plain surfaces can be recognized by one or more of the following characteristics: presence of an A horizon, organic matter accumulation from decaying vegetation, lateral extent (a buried surface is parallel to the land surface and may truncate geologic bedding), root traces, and soil structure (Birkland, 1984; Retallick, 1985). Sometimes part of a buried soil will be removed by scour activity associated with flooding, channel migration, or channel avulsion.

\section{Reach Characterization of Geomorphic Processes}

Helicopter video footage and historical aerial photographs provided evidence of incision, lateral- migration, avulsion, bluff and terrace erosion, bank erosion, overbank sedimentation, and lateral and midchannel-bar formation. These data were supplemented with valley cross sections and cores, which provided information on the vertical stability of the channels and overbank sedimentation. GLO survey notes were useful for determining channel-width changes after pre-Euro-American settlement and logging. Inter-Fluve, Inc.'s reach-assessment data were used for comparison and verification (Inter-Fluve, Inc. and Graber, 2003). More detailed information was collected for the Cranberry River basin than for the basins of streams on the eastern side of the peninsula, such as North Fish Creek, Whittlesey Creek, and the Sioux River; the geomorphic impacts from logging and clearing for agricultural land were expected to be less in the Cranberry River basin than in the basins for the eastern streams.

\section{Determination of Sediment Sources}

Observations from helicopter video footage, combined with field notes from USGS and Inter-Fluve, Inc. field surveys, were used primarily to estimate relative contributions of sediment from upland, road crossings, bluff/terraces, banks, incision, feeder channels, and gullies. These observations were compared to a sediment budget previously done for North Fish Creek on the basis of valley cross sections, core data, and three years of total sediment-load data (Rose and Graczyk, 1996; Fitzpatrick and others, 1999). The previously published North Fish Creek sediment budget also was updated to include sediment inputs from two additional sources - channel 
incision in tributaries that directly feed to the main stem valley and road crossings.

\section{Evaluation of Previous Erosion-Control Techniques}

Six sites of previous erosion-control projects were revisited in May 2003 (fig. 1). The six sites were evaluated for geomorphic stability and effectiveness of the erosion-control techniques. The sites included eroding bluffs on the Bois Brule River (site 64), North Fish Creek (site 68, 69), and Whittlesey Creek (site 66); another site on the lower main stem of Whittlesey Creek with bank erosion problems (site 67); and an eroding waterway from a farmstead (tributary to South Fish Creek) (site 65). A geomorphic-assessment form was used that included detailed measurements and observations of the valley, channel, and bank characteristics based upon Thorne (1998) and an assessment of the restoration structure and effectiveness based upon Brown (2000).

Three of the six evaluated sites (sites 64, 65, 66) were RCIC projects. The RCIC was established in 1956 with members from seven federal, state and local agencies, who worked with local landowners to evaluate erosion problems and potential solutions (Red Clay Interagency Committee, 1957). Restoration practices that were implemented include: resloping banks; testing seed, fertilizer and mulch mixtures for vegetative stabilization; toe stabilizations; and smoothing small gullies and rills prior to seeding (Red Clay Interagency Committee, 1957, 1960, 1967, 1971, 1972, 1977). In 1971, the Governor of Wisconsin requested that the RCIC develop a large-scale plan for reducing erosion in all of the Wisconsin streams that flow into Lake Superior (Red Clay Interagency Committee, 1971). They assisted in the creation of the Red Clay Project, a larger restoration project that involved five counties and had 21 cooperators in two states (Andrews and others, 1976). As part of that project, the RCIC was asked to evaluate the restoration practices that had been installed between 1958 and 1967 (Red Clay Interagency Committee, 1972, 1977, Andrews and others, 1979). After ten to twenty years, the majority of the sites were still intact and functioning well (Red Clay Interagency Committee, 1977). The lessons learned by the RCIC were the importance of toe stabilization when stabilizing a bluff or bank, and the necessity proper slope modification and seeding mixtures for establishing good vegetation cover.

The Ashland-Bayfield-Douglas-Iron Counties Land Conservation Department (ABDI-LCD) and the Natural Resources Conservation Service (NRCS) installed a demonstration restoration project on the lower main stem of Whittlesey Creek in 1995-96 (site 67, fig. 1). The project combined several soft engineering and bioengineering techniques including vortex weirs, rock barbs, brush mattresses, live fascine, live stakes, and brush layers. The purpose of the project was to reduce bank erosion and sedimentation and to improve fish habitat in Whittlesey Creek (Gardner and Johnson, circa 1997).
Two bluff-erosion sites on North Fish Creek where erosion control had previously been attempted were qualitatively evaluated (sites 68 and 69, fig. 1). With the assistance of the ABDI-LCD, design plans for a 1977 stabilization of the bluff at site 68 were found. The plans for site 68 detailed the construction of a new riprapped channel through the flood plain on the inside of a meander bend to divert flow away from the base of an eroding bluff. The plans were to seed and mulch the bluff face and fill the old channel with material from the new channel. Funding was never obtained for this project, but previously in the 1930s there had been an attempt to divert the channel away from bluff face through the point-bar side of the flood plain by dynamiting a new channel (Florence Koleski, landowner, Ashland, Wis., oral commun., 2003). At site 69, live willow stakes were planted in 1991 at the base of the bluff, but were killed by blight during the first year.

\section{Simulation of Flood Peaks and Hydrographs}

The HEC-1 flood hydrograph package (U.S. Army Corps of Engineers, Hydrologic Engineering Center, 1998) was used to simulate flood peaks and hydrographs for the Cranberry River. The Cranberry River basin was divided into 21 subbasins on the basis of tributary junctions and similarities in soils, land cover, and slopes (table 3). Basin and subbasin boundaries were derived from 10-m DEM data (Benchmark GIS, 2001). The surface water-contributing basin derived from DEM data and used in the HEC-1 model had an area of $30.2 \mathrm{mi}^{2}$, compared to the basin area of $31.0 \mathrm{mi}^{2}$ derived from hand-digitizing drainage divides from USGS 7.5-minute topographic maps. Soils data (scale 1:12,000) (U. S. Department of Agriculture, Natural Resources Conservation Service, in press) (fig. 7) were generalized into nine categories by hydrologic soil group (all soils in a hydrologic soil group are assumed to have the same runoff amounts under similar storm and ground-cover conditions) and texture (table 4). A soil category was considered significant if it made up 15 percent or more of a subbasin area. Land-cover data (Reese and others, 2002) were generalized into six categories (table 4), and mixed and deciduous forest categories were grouped into one category. Land cover was considered significant if it made up 10 percent or more of a subbasin area.

Each of the 21 subbasins was further subdivided into Hydrologic Response Units (HRUs) on the basis of the significant land cover and soil type. An HRU was created for every combination of soil and land cover. Areas of land cover and soil type that were not significant were divided among the significant HRUs based on the ratio of HRU area to total area. Thus, if 60 percent of the basin was in HRU1, then 60 percent of the insignificant area was classified as the same land cover and soil type as HRU1. The area-weighted average of all HRU areas in each subbasin was input into the HEC-1 model.

The Soil Conservation Service (SCS) curve-number method was used for runoff-volume estimation and the SCS unit-hydrograph method was used for flow routing 
(U.S. Department of Agriculture Soil Conservation Service, 1986). Soil and land-cover data were used to determine SCS curve numbers. For the SCS unit-hydrograph method, slope and roughness for both overland and channel were used to calculate the timing of runoff through each subbasin. A detailed description of both methods can be found in the National Engineering Handbook (Soil Conservation Service, 1972). Overland-flow roughness coefficients are based on Engman (1986). Inter-Fluve, Inc.'s channel-survey data were used for channel cross-section inputs.

Design storms were used to estimate rainfall distributions, because no long-term precipitation stations are near the Cranberry River. The design storms included the 24-hour rainfalls for Bayfield County with return intervals of 2-, 10-, and 100-years (2.77, 4.04, and 5.98 in., respectively) (Huff and Angel, 1992). Rainfall volumes were distributed by using the SCS type-II rainfall distribution (Soil Conservation Service, 1972).
Four alternative land-cover scenarios were simulated with the Cranberry River HEC-1 model (table 5). The first simulation used 1992-93 land cover WISCLAND data to represent present land-cover conditions. Percentages for 1992-93 land cover in the Cranberry River watershed are slightly different in table 5 compared to table 1 because, as explained above, only land-cover categories that made up 10 percent or more of a subbasin area were included. The second simulation (peak agriculture) used land-cover data from the 1928 Land Economic Inventory (Wisconsin Department of Agriculture and Wisconsin Geological and Natural History Survey, 1928) and represents the 1920s and 1930s, when row-crop agriculture was at its peak. A third simulation (developed) was made by adjusting all curve numbers for each land cover in each HRU (except for wetland) to include 25-percent urban residential land. For the fourth simulation (presettlement), all landcover categories from the 1928 Land Economic Inventory (other than wetland) were replaced with forest. Additionally,

Table 3. Physical characteristics of subbasins used in the Cranberry River HEC-1 flood hydrograph simulations, Bayfield Peninsula, Wisconsin.

$\left[\mathrm{mi}^{2}\right.$, square miles; ft, feet; mi, miles]

\begin{tabular}{|c|c|c|c|c|c|c|c|c|}
\hline Subbasin & Area $\left(\mathrm{mi}^{2}\right)$ & $\begin{array}{l}\text { Average basin } \\
\text { slope length (ft) }\end{array}$ & $\begin{array}{l}\text { Average basin } \\
\text { slope }\end{array}$ & $\begin{array}{c}\text { Average width of } \\
\text { channel at top of } \\
\text { bank ( } \mathrm{ft} \text { ) }\end{array}$ & $\begin{array}{l}\text { Average depth of } \\
\text { main channel; top of } \\
\text { bank to bottom (ft) }\end{array}$ & $\begin{array}{l}\text { Main } \\
\text { channel } \\
\text { slope }\end{array}$ & $\begin{array}{c}\text { Main } \\
\text { channel } \\
\text { length (mi) }\end{array}$ & $\begin{array}{l}\text { Channel } \\
\text { width to } \\
\text { depth ratio }\end{array}$ \\
\hline 1 & 1.2 & 60 & 0.199 & 58 & 2.4 & 0.007 & 1.6 & 24 \\
\hline 2 & 0.94 & 60 & 0.188 & 7.2 & 0.6 & 0.057 & 0.30 & 12 \\
\hline 3 & 1.6 & 0.2 & 0.326 & 10 & 0.8 & 0.065 & 2.0 & 13 \\
\hline 4 & 2.6 & 50 & 0.202 & 53 & 2.3 & 0.011 & 2.3 & 23 \\
\hline 6 & 0.52 & 80 & 0.160 & 21 & 1.2 & 0.030 & 0.35 & 17 \\
\hline 7 & 1.4 & 60 & 0.193 & 9.0 & 0.7 & 0.038 & 0.05 & 13 \\
\hline 8 & 0.60 & 60 & 0.166 & 17 & 1.1 & 0.035 & 0.42 & 16 \\
\hline 9 & 2.1 & 80 & 0.148 & 12 & 0.8 & 0.025 & 1.3 & 14 \\
\hline 13 & 2.2 & 50 & 0.226 & 12 & 0.8 & 0.061 & 2.6 & 14 \\
\hline 14 & 3.1 & 0.2 & 0.268 & 15 & 1.0 & 0.047 & 3.1 & 15 \\
\hline 15 & 0.91 & 50 & 0.230 & 7.1 & 0.6 & 0.040 & 0.31 & 12 \\
\hline 16 & 1.6 & 0.2 & 0.340 & 19 & 1.1 & 0.063 & 2.0 & 16 \\
\hline 17 & 1.3 & 0.2 & 0.331 & 18 & 1.1 & 0.035 & 1.7 & 16 \\
\hline 18 & 1.3 & 50 & 0.242 & 8.6 & 0.7 & 0.010 & 0.92 & 13 \\
\hline 19 & 0.47 & 0.2 & 0.335 & 11 & 0.8 & 0.031 & 0.80 & 14 \\
\hline 20 & 3.0 & 60 & 0.187 & 15 & 1.0 & 0.036 & 1.35 & 15 \\
\hline 21 & 1.4 & 0.2 & 0.332 & 9.3 & 0.7 & 0.061 & 0.63 & 13 \\
\hline
\end{tabular}


Table 4. HEC-1 model input-parameter values for Cranberry River, Wisconsin for four land-cover simulations.

[SCS, Soil Conservation Service (1972); —, no data]

\begin{tabular}{|c|c|c|c|c|c|}
\hline Land cover & Soil & 1992-93 & $\begin{array}{c}\text { Presettlement } \\
\text { (before 1870) }\end{array}$ & $\begin{array}{c}\text { Peak agriculture } \\
\text { (1928) }\end{array}$ & Developed \\
\hline \multicolumn{6}{|c|}{ SCS curve number } \\
\hline Forest, pine & Sand & 30 & 28 & 30 & 30 \\
\hline Forest, pine & Loam A & 42.5 & - & - & 42.5 \\
\hline Forest, deciduous/mixed & Sand & 45 & - & - & 45 \\
\hline Forest, deciduous/mixed & Loam A & 55.5 & 42 & 56 & 55.5 \\
\hline Forest, deciduous/mixed & Loam B & 66 & 55 & 66 & 66 \\
\hline Forest, deciduous/mixed & Sand over loam & 66 & - & - & 66 \\
\hline Forest, deciduous/mixed & Sand over clay & 66 & 55 & 66 & 66 \\
\hline Forest, deciduous/mixed & Loam over clay & 77 & 70 & 77 & 77 \\
\hline Forest, deciduous/mixed & Clay over loam & 83 & 77 & 83 & 83 \\
\hline Forest, deciduous/mixed & Clay & 83 & 77 & 83 & 83 \\
\hline Rangeland/brush & Sand & 49 & - & - & 49 \\
\hline Rangeland/brush & Loam A & 50 & - & - & 50 \\
\hline Rangeland/brush & Loam B & 61 & - & - & 61 \\
\hline Grassland & Sand over clay & 69 & - & - & 69 \\
\hline Grassland & Loam B & 69 & - & - & 69 \\
\hline Grassland & Loam over clay & 79 & - & - & 79 \\
\hline Grassland & Clay over loam & 84 & - & - & 84 \\
\hline Grassland & Clay & 84 & 83 & 83 & 84 \\
\hline Wetland & Sand & - & 60 & 60 & - \\
\hline Wetland & Loam B & - & 72 & 72 & - \\
\hline Wetland & Sand over clay & - & 76 & 76 & - \\
\hline Wetland & Silt/muck & - & 83 & 83 & - \\
\hline Wetland & Clay & 83 & - & - & 83 \\
\hline Agriculture & Loam B & - & - & - & - \\
\hline Agriculture & Clay over loam & - & - & - & - \\
\hline Agriculture & Clay & - & - & - & - \\
\hline Developed & Sand & - & - & - & 61 \\
\hline Developed & Loam A & - & - & - & 68 \\
\hline Developed & Loam B & - & - & - & 75 \\
\hline Developed & Sand over loam & - & - & - & 75 \\
\hline Developed & Sand over clay & - & - & - & 79 \\
\hline Developed & Loam over clay & - & - & - & 83 \\
\hline Developed & Clay over loam & - & - & - & 87 \\
\hline Developed & Clay & - & - & - & 87 \\
\hline \multicolumn{6}{|c|}{ Overland flow roughness coefficient } \\
\hline Forest, pine & All & 0.40 & 0.8 & 0.8 & 0.25 \\
\hline Forest, deciduous & All & 0.60 & 0.8 & 0.8 & 0.25 \\
\hline Rangeland/brush & All & 0.13 & - & - & 0.13 \\
\hline Grassland & All & 0.15 & - & - & 0.15 \\
\hline Wetland & All & 0.15 & 0.8 & 0.8 & 0.15 \\
\hline Agriculture & All & - & - & 0.14 & - \\
\hline \multicolumn{6}{|c|}{ Channel roughness coefficent (Manning's n) } \\
\hline All & All & $0.035-0.05$ & 0.15 & $0.035-0.05$ & $0.035-0.05$ \\
\hline
\end{tabular}


Table 5. Percentages of land-cover types used in the Cranberry River, Wisconsin from HEC-1 model simulations.

[All data are percentages. 1992-93 land cover from WISCLAND land cover (Reese and others, 2002). Peak agriculture data from 1928 Land Economic Inventory (Wisconsin Department of Agriculture and Wisconsin Geological and Natural History Survey, 1928). —, no data]

\begin{tabular}{lcccc}
\hline & $\mathbf{1 9 9 2 - 9 3}$ & $\begin{array}{c}\text { Peak agriculture } \\
\text { (1928) }\end{array}$ & Developed & $\begin{array}{c}\text { Presettlement } \\
\text { (before 1870) }\end{array}$ \\
\hline Agriculture & - & 3.4 & - & - \\
Forest & 91.1 & 94 & 68.3 & 97.4 \\
Brushland & 1.6 & - & 1.2 & - \\
Grassland/pasture & 6.8 & - & 5.1 & - \\
Wetland & 0.5 & 2.6 & 0.5 & 2.6 \\
Urban & - & - & 24.9 & - \\
\hline
\end{tabular}

overland and channel roughness coefficients in the model were increased to the maximum published values for forest to simulate the greatest reasonable amount of organic debris in the upland forest floors and the greatest reasonable amount of woody debris in the stream channel.

The flood hydrographs simulated with HEC-1 could not be calibrated because there are no streamflow-gaging stations in the Cranberry River Basin. Data sources and model inputs were similar to data sources and inputs used in the Whittlesey Creek rainfall-runoff model (Lenz and others, 2003) and the North Fish Creek HEC-1 model (Fitzpatrick, 1998). Results from the Cranberry River HEC-1 simulations, however, should be used only for comparisons among land-cover scenarios for the Cranberry River and rough comparisons to the Whittlesey Creek and North Fish Creek models. The Whittlesey Creek and North Fish Creek models, on the other hand, were calibrated to historical rainfall data and streamflow and stage data from USGS streamflow-gaging stations.

\section{Simulation of Groundwater Flow}

A groundwater-flow model was used to determine the general hydrogeologic characteristics of the study area and the base-flow characteristics for the streams of interest. Additionally, the model was used to determine the groundwater divide between the east and west sides of the peninsula and to delineate the groundwater contributing areas to the streams of interest.

Groundwater flow for the study area was simulated by using a two-dimensional analytic-element model (GFLOW, Haitjema, 1995). The analytic-element methodology is not as widely utilized for numerical modeling as finite-difference techniques, but has been successfully employed by others for basin- and regional-scale investigations (Hunt and Krohelski, 1996; Hunt and others, 1998, 2000). A complete description of analytic elements is beyond the scope of this report; a brief description is given below. Strack (1989) and Haitjema (1995) provide detailed discussions of this method.

An infinite aquifer is assumed in analytic-element modeling. The problem domain does not require a grid or involve interpolation between cells. To construct an analytic-element model, features that affect groundwater flow (such as surfacewater bodies, aquifer characteristics, and recharge) are entered as mathematical elements or strings of elements. The amount of detail specified for the features depends on distance from the area of interest. Each element is represented by an analytic solution. The effects of these individual solutions are added together to give a solution for the groundwater-flow system. Because the solution is not confined to a grid, heads and flows can be computed anywhere in the model domain without nodal averaging. In the GFLOW model, the analytic elements are two dimensional and are used to simulate only steady-state conditions. Groundwater-flow systems are three dimensional; however, two-dimensional models can provide reasonable approximations of groundwater flowlines when the lengths of the flowlines are large compared to the aquifer thickness (Haitjema, 1995, p. 23). In the study area, most groundwater is assumed to move through unconsolidated deposits that have a maximum saturated thickness of several hundred feet or less and the upper part of the bedrock. The lengths of flowlines from recharge areas to discharge areas are typically several miles or more in length.

The GFLOW model domain included all major streams in the vicinity of the peninsula, ranging from the Bois Brule River in the west to the Bad River in the east (fig. 1). Other surface-water features included Lake Superior to the north and several streams to the south of the peninsula. The geometry of the single model layer includes a flat bottom altitude initially set at approximately $550 \mathrm{ft}$ and an aquifer thickness ranging from about 100 to $600 \mathrm{ft}$. The single model layer represents all of the saturated unconsolidated deposits overlying the Bayfield 
Group and upper parts of the Bayfield Group. The bottom of this one layer model is assumed to be a no-flow boundary. Zones of horizontal hydraulic conductivity $\left(\mathrm{K}_{\mathrm{h}}\right)$ and recharge to the groundwater system are represented in the GLFOW model as inhomogeneities, and primarily represent the sandy deposits of the Copper Falls Formation and the clayey Miller Creek Formation (fig. 5).

The GFLOW model includes near-field and far-field linesinks, which are lines of flow that transcend surface-water and groundwater systems (fig. 10). Streams are simulated as coarse linesinks that have little or no resistance between the surfacewater and the groundwater systems. The near field is the area of interest and includes the nearshore area of Lake Superior and streams around the perimeter of the peninsula from the Flag River to North Fish Creek. The far field surrounds the near field and is used to simulate the regional groundwaterflow field in the vicinity of the area of interest. Many of the near-field streams are used for flux calibration; far-field streams are not. Near-field streams are simulated as slightly more detailed linesinks with streambed resistance to control groundwater/surface-water interaction. In GFLOW, resistance is calculated by dividing streambed sediment thickness by the vertical hydraulic conductivity $\left(\mathrm{K}_{\mathrm{v}}\right)$ of the sediments and is in units of days. Values of resistance for near-field streams ranged from 0.01 to 10 days and correspond to values measured and estimated for Whittlesey Creek and vicinity (Lenz and others, 2003). High resistance values (10 days) were assigned to small streams like Boyd Creek (fig. 1). Low resistance values ( 0.01 to 0.02 days) were assigned to all other near-field streams. The linesinks representing streams and lakes were assigned altitudes based on USGS 7.5-minute quadrangle maps. Near-field streams were assigned stream widths (ranging from 2 to $75 \mathrm{ft}$ ) based on field measurements and stream order. The linesink representing Lake Superior was given a very high resistance (100 days) based on the value used in a calibrated groundwater model for Whittlesey Creek (Lenz and others, 2003) and width of $612 \mathrm{ft}$ (based on stream/ lake linesink-width calculations (Hunt and others, 2003).

\section{Base-Flow Measurements}

Base flow is the discharge entering a stream channel from groundwater or other sources that release water in a gradual manner (American Society of Civil Engineers, 1949). Baseflow discharge was measured over 2 days during a low-flow period in November 2002 at 45 sites in 11 watersheds on the Bayfield Peninsula by use of standard USGS techniques (Buchanan and Somers, 1984) (fig. 1, table 2). Streambed temperature also was measured at the discharge locations using a thermometer inserted into the streambed about $2 \mathrm{~cm}$ (Shelton and Capel, 1994). Sites were chosen on the five study-area streams as well as six adjacent streams. Discharge measurements deemed to represent base flow were used as flux targets in the groundwater-flow simulation. Sites were not included in the model for three reasons: (1) the stream was not included in the GFLOW model, (2) the site was too close to Lake Superior to adequately measure discharge, or (3) measured discharge was less than $0.1 \mathrm{ft}^{3} / \mathrm{s}$, which can be difficult to simulate accurately using a regional model.

\section{Estimates of Hydraulic Conductivity and Recharge}

Initial estimates of horizontal hydraulic conductivity $\left(\mathrm{K}_{\mathrm{h}}\right)$ for the areas underlain by the Copper Falls and Miller Creek Formations were based on previously estimated values used in the simulation of groundwater flow for Whittlesey Creek (Lenz and others, 2003). Hydraulic conductivity was estimated to be about $70 \mathrm{ft} / \mathrm{d}$ in the area underlain by the Copper Falls Formation and about $34 \mathrm{ft} / \mathrm{d}$ in the area underlain by the Miller Creek Formation. For this study, the area underlain by the Miller Creek Formation was divided into two zones (inhomogeneities): one for the north and west side of the peninsula and one for the east side (fig. 10). Available well logs, in addition to geologic (Soller and Packard, 1998) and soils (Schwarz and Alexander, 1995) data, indicate that the Miller Creek Formation on the north and west sides of the peninsula may be slightly thinner and less permeable than on the east side. Thinner, less permeable materials could result in lower $\mathrm{K}_{\mathrm{h}}$ and recharge for the north and west sides of the study area. Dividing the Miller Creek Formation area into two zones allowed this hypothesis to be tested during model calibration.

Initial estimates of groundwater recharge in the study area were also based on previous estimates from the Whittlesey Creek groundwater-flow model (Lenz and others, 2003). The value used for the area underlain by the Copper Falls Formation was $17 \mathrm{in} / \mathrm{yr}$. Recharge for both areas underlain by the Miller Creek Formation was estimated to be 2 in/yr. Estimates of $\mathrm{K}_{\mathrm{h}}$ and recharge were updated during model calibration. Groundwater pumping was not included in model simulations. Groundwater pumping in the study area is typically from domestic wells and several municipal wells. Municipal pumping is typically from the Bayfield Group and generally from parts of the aquifer that are deeper than that simulated by the GFLOW model.

\section{Parameter Sensitivity and Model Calibration}

Forty-five head targets (groundwater levels) and 26 flux targets (base flows) were used for the GFLOW model calibration (fig. 10). Head targets were compiled by using depthto-water information from drillers' logs. Depth to water was converted to water-level altitude based on site location and land-surface altitudes on USGS 7.5-minute quadrangle maps. Flux targets included base-flow measurements made during November 2002 at multiple locations for the 11 streams in the study area. Model parameters were adjusted within expected ranges until simulated heads and base flows were similar to measured values.

The computer program UCODE (Poeter and Hill, 1998) was used for parameter sensitivity testing and automatic 


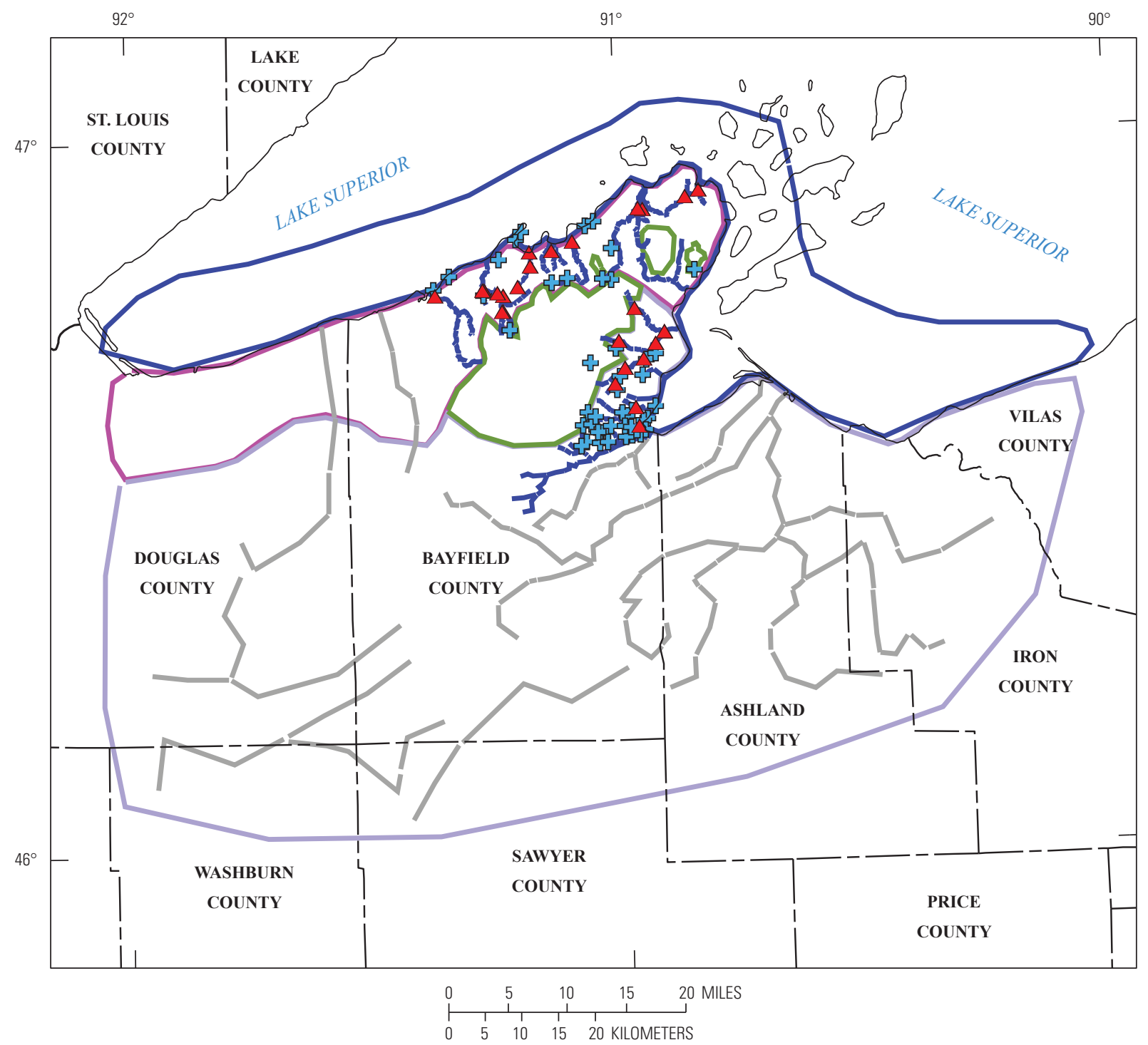

EXPLANATION

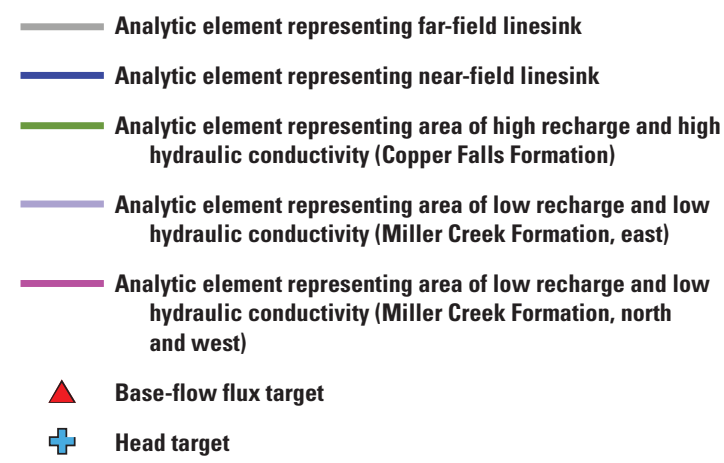

Figure 10. Hydrologic features simulated with analytic elements for the GFLOW model of the Bayfield Peninsula, Wisconsin. 
calibration of the GFLOW model. Observations used for sensitivity testing and model calibration include those for the 45 head and 26 flux targets. Observation weights were assigned as follows: all heads, standard deviation $=5 \mathrm{ft}$; streams with measured base flow greater than or equal to $1 \mathrm{ft}^{3} / \mathrm{s}$, coefficient of variation $=0.1$; streams with measured base flow less than $1 \mathrm{ft}^{3} / \mathrm{s}$, coefficient of variation $=0.15$. Higher values of standard deviation and coefficient of variation represent a greater level of uncertainty in those measured values. Parameters tested for sensitivity were: $\mathrm{K}_{\mathrm{h}}$ of the Copper Falls and Miller Creek Formations (three zones), recharge (three zones), Lake Superior linesink resistance, and the altitude of the model-layer bottom. Parameters used in model calibration were: $\mathrm{K}_{h}$, recharge, and model-layer bottom altitude.

\section{Delineation of Groundwater Contributing Areas}

The groundwater contributing areas for the five Bayfield streams were delineated by using the particle-tracking options in GFLOW. Particles were tracked forward from recharge areas to determine the groundwater contributing areas. The areal extent of the pathlines traced by the particle movement was manually digitized and represents the groundwater contributing area. In this report, "groundwater contributing area" refers to the two-dimensional land-surface area projected from the three-dimensional subsurface volume of water discharging to the streambed of the five streams.

\section{Geomorphic Characteristics}

The geomorphic characteristics of the five Bayfield streams are described in this section from multiple sources and for several scales of data. First, the general effects of geologic setting (glacial and post-glacial history) on longitudinal profiles and valley types for the streams are described. Next, geomorphic characteristics and processes for individual main stem channels are described longitudinally from their headwaters to their mouths at Lake Superior. Site specific estimates of bankfull-channel shear stress are related to reachscale geomorphic processes and reaches identified with brooktrout fingerlings. Relative contributions of sediment sources are compared among the streams. Lastly, results from the evaluation of previous erosion-control and bank-stabilization activities are described.

\section{Longitudinal Profiles}

Bayfield Peninsula streams have somewhat similar concave-up longitudinal profiles with steep, erosional zones in the headwaters, low-slope, depositional zones near the Lake Superior shore, and irregularities caused by bedrock outcrops and post-glacial shorelines (fig. 11). Geomorphic characteristics and processes along a particular reach are dependent on the location of the reach within the drainage network and along the longitudinal profile. The headwaters of the Cranberry River, Sioux River, and Whittlesey Creek start near the boundary between the clayey Miller Creek Formation and the sandy Copper Falls Formation at about 1,100 ft. This altitude also is the approximate upper limit of the altitude of glacial Lake Duluth at about 9,900 years before present (yr BP) (Clayton, 1984). The headwaters of the Bark River extend to an altitude of only about $850 \mathrm{ft}$.

Longitudinal profiles from the headwaters to the mouth of a stream are usually concave up (steep slopes in the headwaters transitioning smoothly to low slopes near the mouth) if the stream flows through homogeneous geologic deposits and landforms (Schumm, 1977). The concave curve that represents the profile is attributed to the exponential relation of downstream increases in stream length to drainage area and discharge (Hack, 1960). In general, relatively steep slopes are prone to long-term erosional conditions, whereas reaches with relatively low slopes are prone to long-term depositional conditions (Knighton, 1998). Irregularities in the profiles are attributed to differences in the erodibility of geologic materials (bedrock, clay till, outwash), existing landforms, or changes in base level (Hack, 1965).

Channel slopes for the entire length of main-stem streams ranged from 0.44 (North Fish Creek) to 1.6 percent (Whittlesey Creek) (table 6). The stream length of Whittlesey Creek is similar to that of the Bark River, but it drops $250 \mathrm{ft}$ more than the Bark River. Slopes for segments of the main stems near the mouths were the lowest and ranged from 0.07 (North Fish Creek) to 0.36 percent (Whittlesey Creek). Upper main-stem segments had the highest slopes where the streams intersect the glacial Lake Duluth shoreline $(1,000-1,100 \mathrm{ft})$. One exception is the Bark River, whose steepest slope is at $690-860 \mathrm{ft}$.

Although North Fish Creek has a large watershed compared to most Bayfield Peninsula streams, the longitudinal profile of North Fish Creek is similar to the profiles of the five studied streams (fig. 11). From altitudes of about 920 to $680 \mathrm{ft}$, eroding bluffs are common along North Fish Creek and geomorphic processes of channel incision and lateral migration are characteristic (Fitzpatrick, 1998; Fitzpatrick and others, 1999). The slope through this reach of North Fish Creek is 1.6 percent. Downstream, the slope decreases to 0.13 percent in the lower main stem and 0.07 percent near the mouth. Overbank sedimentation, channel aggradation, and channel avulsion (a sudden and abrupt change in the course of a river) are common geomorphic processes in the lower main stem of North Fish Creek. In general, Bayfield streams above about $650+30 \mathrm{ft}$ with greater than 1-percent slopes are likely erosional, whereas streams below about $650+30 \mathrm{ft}$ with slopes less than 1 percent are likely depositional. Each stream may have a short intermediate reach with mainly sediment transport. 


\section{Valley Development and Stream Meandering}

Valley development and meandering for Bayfield Peninsula streams were grouped into four types (fig. 12). These types were based on modifications of categories assigned to valleys for streams in the western part of the Upper Peninsula of Michigan by Hack (1965). The valley types are evident on the DEM maps of individual basins (figs. 13A-17A). Headwater streams in the upstream parts of the watersheds have no valleys, are unconfined (U), and flow over glacial deposits. As drainage area increases and altitude decreases, the streams have confined (C), V-shaped valleys as they cut through the steep, post-glacial shoreline areas. With further increases in drainage area and decreases in altitude, the valleys become well developed but stream meanders follow the valley meanders (E). This type of valley and stream-meander pattern was called entrenched by Hack (1965). The stream-meander pattern for this valley type tends to be irregular and determined by the intersection of the stream and valley with bedrock outcrops, and in the case of Bayfield streams, probably old postglacial-lake shorelines. Channels commonly intersect valley sides, which, combined with enough flow and shear stress, can cause bluff and terrace erosion. Near the mouths, valleys are wide and unconfined and stream-meander patterns are alluvial (A). The valleys are wider than the meander belt and stream meanders are a reflection of fluvial processes of runoff and sediment transport. Compound stream meanders are formed when alluvial meanders are superimposed over entrenched meanders (Hack, 1965).

At an altitude of about $650 \mathrm{ft}$, all streams exhibit some slope steepening (figs. 11, 13B-17B). At this altitude the valleys are narrow, with wider valleys and lower slopes above and below. The courses of the stream and sometimes the valley shift at this altitude as well. Some streams in the vicinity of the peninsula have outcrops of sandstone at this altitude, such as South Fish Creek, the White River, and the Bad River to the south and east of Ashland. Big Rock Falls on the Sioux River is at an altitude of about $650 \mathrm{ft}$ (site 8 in reach $\mathrm{K}$, figs. 16A-B). Other streams have similarly steepened longitudinal profiles at $650 \mathrm{ft}$ but no evidence of rock outcropping, such as North Fish Creek, Whittlesey Creek, Raspberry River, Bark River, and Cranberry River.

The narrow valleys and steep slopes at about $650 \mathrm{ft}$ on the longitudinal profiles give some indication of how the

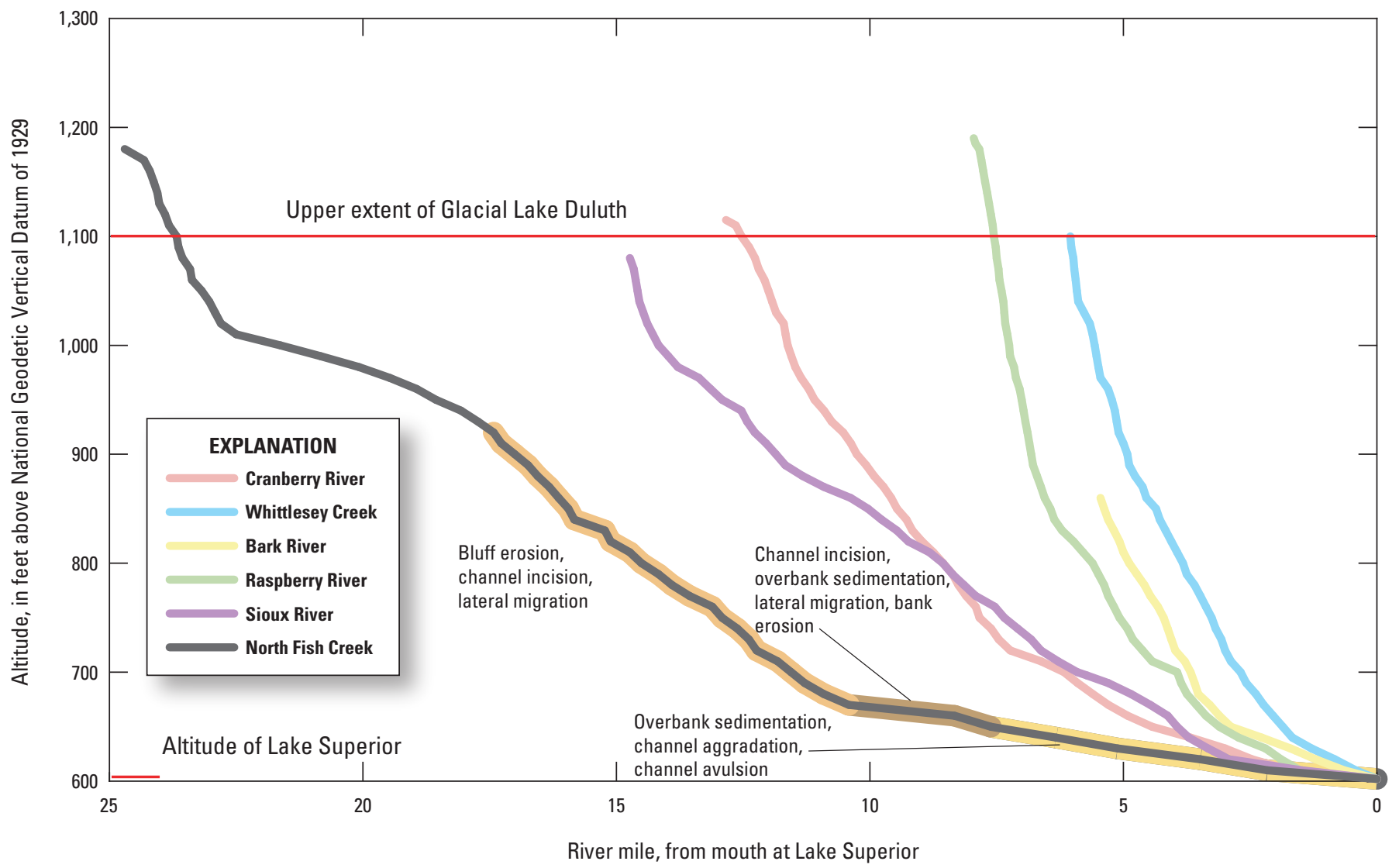

Figure 11. Comparison of longitudinal profiles for six Bayfield peninsula streams. 
Table 6. Comparison of average and range of slopes for selected Bayfield Peninsula streams, Wisconsin, based on longitudinal profiles.

[Reaches are delineated as stream lengths between contour-line crossings on U.S. Geological Survey 7.5-minute topographic maps.]

\begin{tabular}{lccc}
\hline & $\begin{array}{c}\text { Slope for entire } \\
\text { main stem } \\
\text { (percent) }\end{array}$ & $\begin{array}{c}\text { Minimum slope for } \\
\text { main-stem reaches } \\
\text { (percent) }\end{array}$ & $\begin{array}{c}\text { Maximum slope for } \\
\text { main-stem reaches } \\
\text { (percent) }\end{array}$ \\
\hline Cranberry River & 0.76 & 0.08 & 5.0 \\
Bark River & 0.90 & 0.24 & 2.5 \\
Raspberry River & 1.4 & 0.10 & 10 \\
Sioux River & 0.61 & 0.10 & 5.0 \\
Whittlesey Creek & 1.6 & 0.36 & 10 \\
North Fish Creek & 0.44 & 0.07 & 5.0 \\
\hline
\end{tabular}

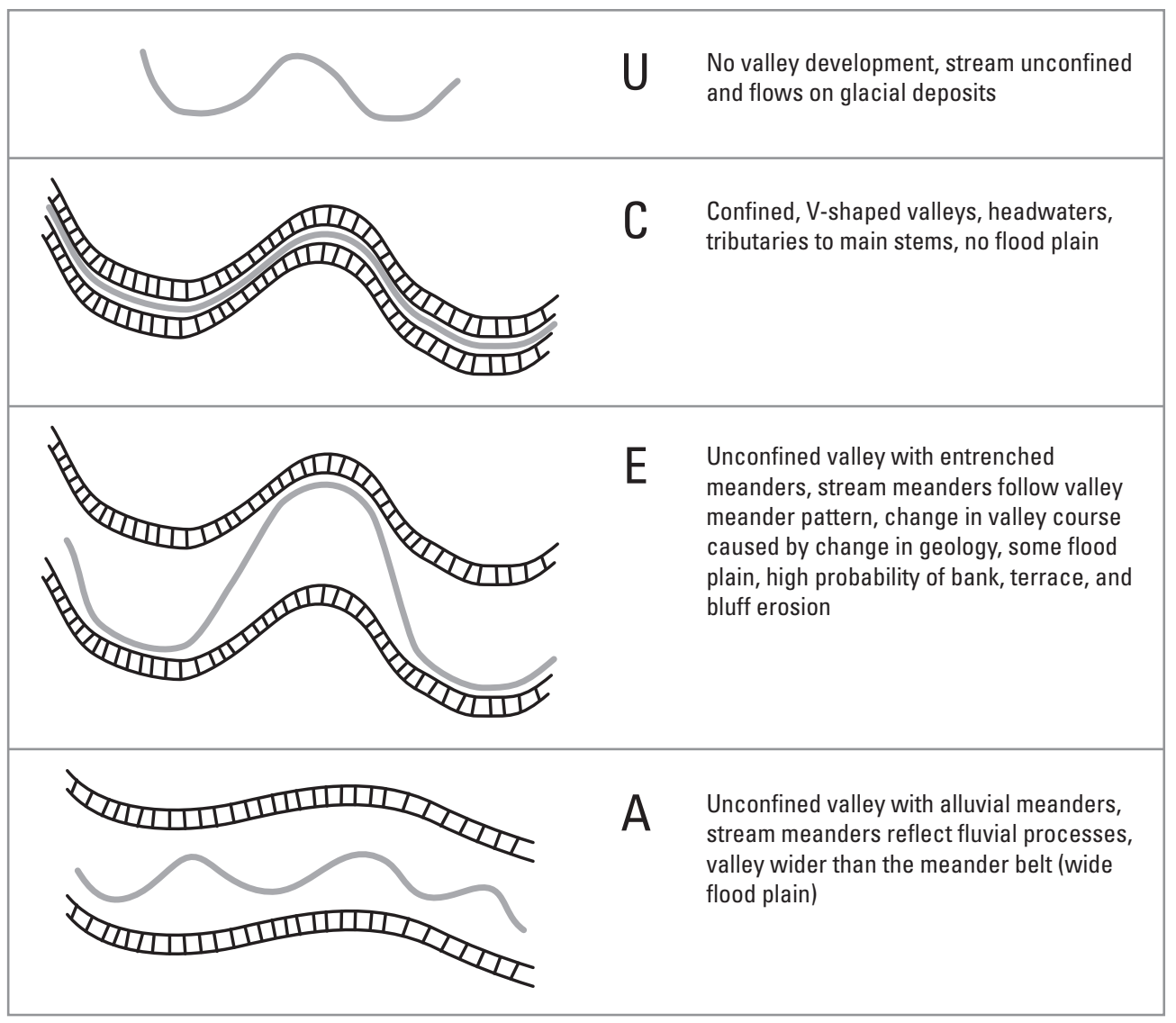

Figure 12. Valley development and types of meandering for Bayfield Peninsula streams. 


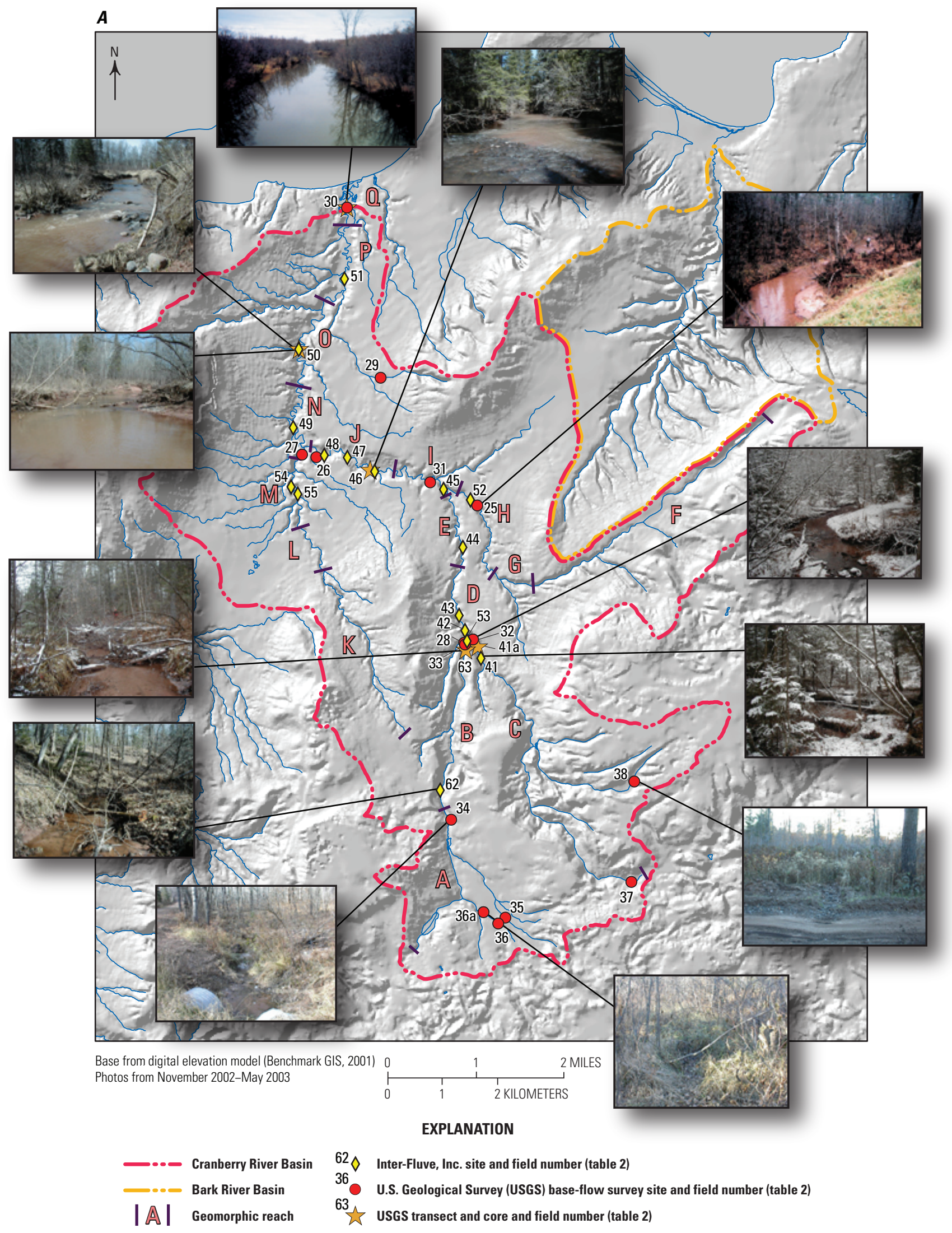

Figure 13. Cranberry River $A$, map, and $B$, longitudinal profile. 
stream networks and valleys developed when postglacial lake levels (and base level) dropped from the postglacial Lake Duluth level of 1,100 ft to below the present level of Lake Superior (602 ft) from about 9,600 to 9,200 yr BP, and then rose to near the present lake level by about 4,000 yr BP (Clayton, 1984). More than seven shorelines have been identified in the vicinity near the Bayfield Peninsula, but it is not known how long it took for each one to form (Clayton, 1984) (fig. 6). Valley and stream patterns change from unconfined with alluvial meanders upstream of $650 \mathrm{ft}$, to confined at about $630-650 \mathrm{ft}$, and then to back to unconfined with entrenched or alluvial meanders downstream of $630-650 \mathrm{ft}$.

\section{Channel-Reach Conditions}

Channel conditions within the five studied basins were categorized into reaches by evidence of incision, bank erosion, terrace or bluff erosion, widening, lateral migration, overbank sedimentation, mid-channel bar formation, and aggradation (table 7). The reaches are shown on DEM maps and on longitudinal profiles (figs. 13-17). The following detailed descriptions of channel conditions for reaches within each studied basin are ordered from upstream to downstream. More detailed geomorphic assessment and coring was done for the Cranberry River compared to the other rivers.

\section{Cranberry River}

Headwater streams in the Cranberry River basin (reaches A, C, F, and K) are sources for runoff but generally not sediment, except for point sources at road crossings (fig. 13, table 7). Forested lands have limited or negligible upland erosion (fig. $13 \mathrm{~A}$, photos at sites $36 \mathrm{a}$ and 38 ). Channels are generally vertically and laterally stable (table 7, fig. 13A). Incipient valleys are present but some headwaters have poorly defined channels in wetlands. Headcutting and gully development of headwater streams are limited but may have been a factor during logging and clearing in the late 1800s. Culverts at gravel-road crossings may act as grade-control structures, but also are major sources of sediment because of frequent washouts. Eroded sections of unimproved gravel or sand roads or trails at swales or ephemeral channel crossings with no culverts are typically regraded as needed after flood events. The lower altitude for these reaches depends on the size of the drainage area (linked to amount of runoff), slope, and texture of surficial deposits and soils. For example, Lenawee Creek reach A extends downstream to about 1,070 ft, whereas

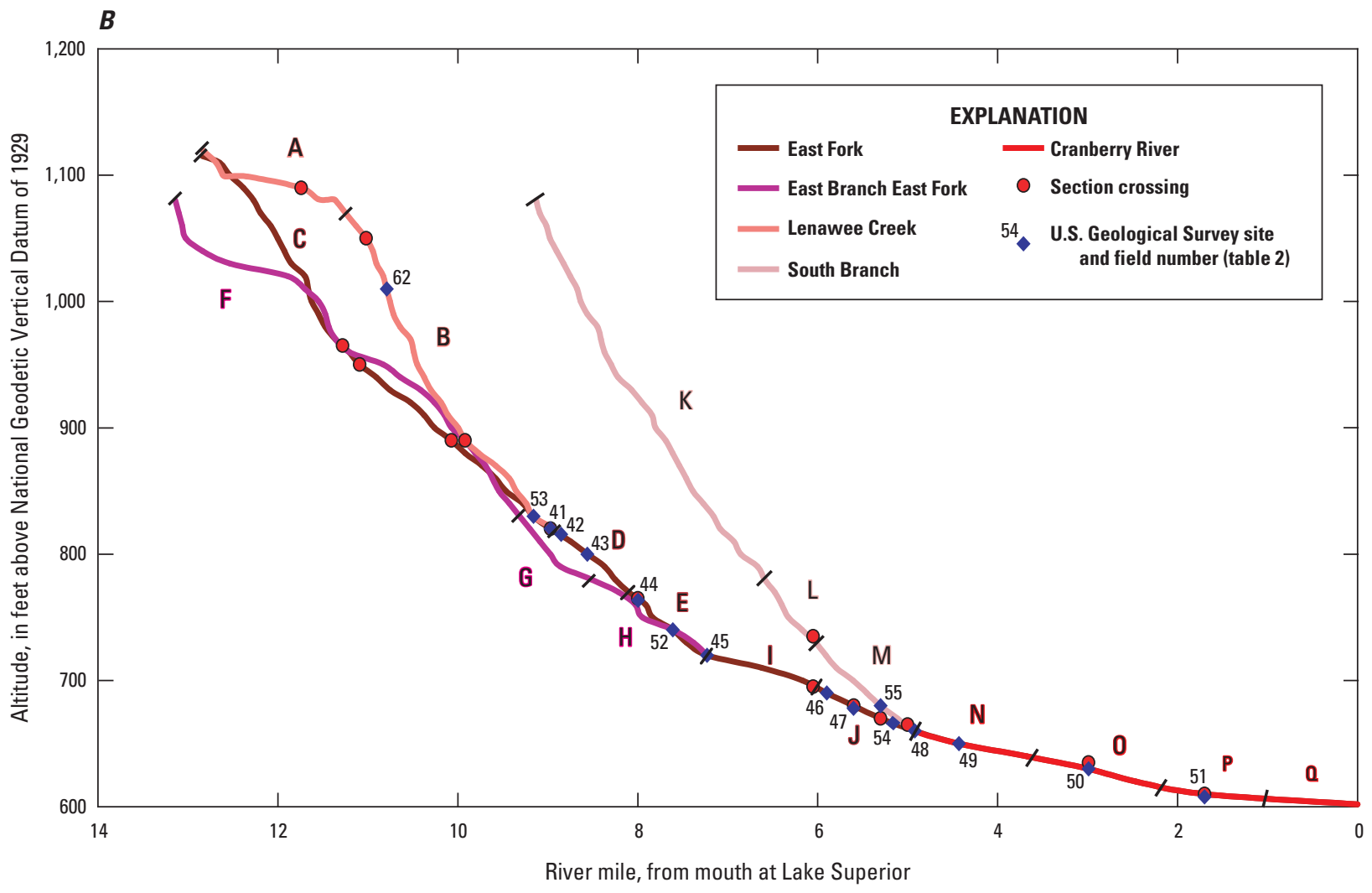

Figure 13. Cranberry River $A$, map, and $B$, longitudinal profile.-Continued 
$\boldsymbol{A}$

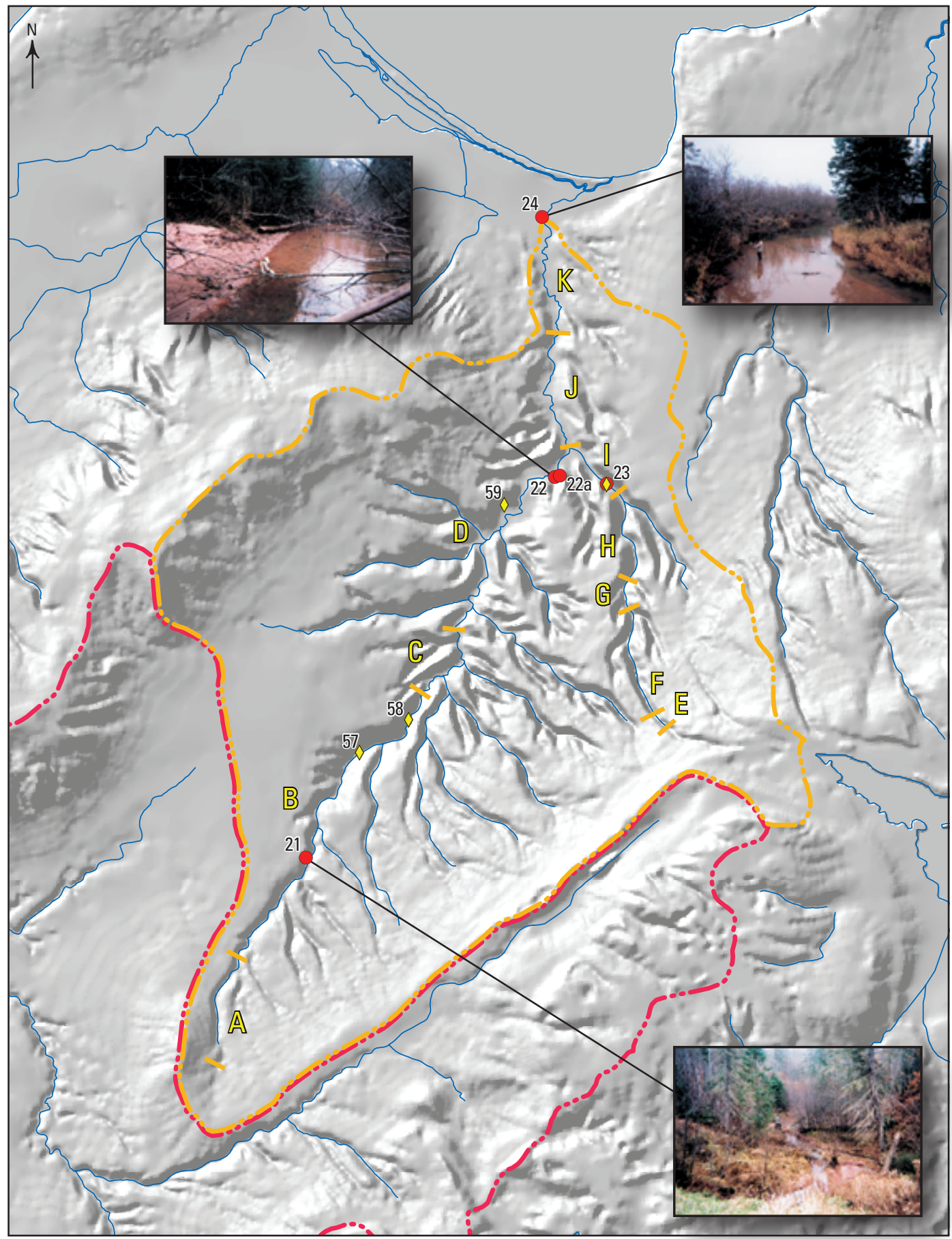

Base from digital elevation model (Benchmark GIS, 2001) Photos from November 2002

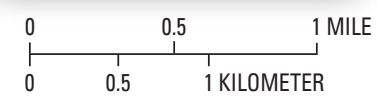

EXPLANATION

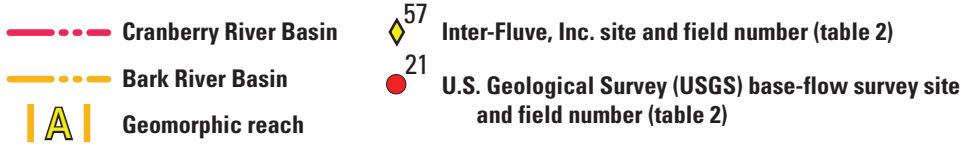

Figure 14. Bark River $A$, map, and $B$, longitudinal profile. 
reach $\mathrm{C}$ for the East Fork of the Cranberry River extends downstream to $817 \mathrm{ft}$. The East Fork upstream of Lenawee Creek has abundant large woody debris (LWD) and brook trout; Lenawee Creek does not. The East Fork basin has more sand soils than the Lenawee Creek basin (81 percent compared to 73 percent) (fig. 7), the valley was cut deeper into glacial deposits (potentially from glacial meltwater) (fig. 13A), and channel slopes are less ( 1.5 percent compared to 2.0 percent) (fig. 13B). Historical log drives and hauling lanes also may have influenced geomorphic conditions - the East Fork had no $\log$ drives upstream of the Lenawee Creek confluence and the Lenawee Creek valley had hauling lanes. A comparison of photos upstream (site 41a) and downstream (site 32) of a historical loading point for log drives at the confluence of Lenawee Creek and the East Fork of the Cranberry River (fig. 13A) illustrates that channels used for log drives have less roughness (less LWD) and larger cross-sectional area compared to channels not used for log drives. Thus it is possible that the headwater channels currently reflect enlargement, incision, and low roughness because of log drives and logging access during the late 1800 s.
An 1852 GLO map of the Cranberry River shows fewer headwater channels and narrower widths of main-stem channels compared to USGS 7.5-minute topographic maps and field surveys (fig. 18; table 7). This suggests that the drainage network possibly had headward expansion caused by increased runoff from clear-cut areas in the late 1800 s, or possibly the 1852 maps of stream networks were less detailed in some areas than in others. Channels have widened over the last 130 years by up to $8 \mathrm{ft}$.

Comparison of a valley cross section at site 63 (Lenawee Creek) and valley cross section and cores at site 41 (East Fork Cranberry River) indicates differences in valley development and channel size between the two tributaries (figs. 19A-B). The Lenawee Creek valley at site 63 is confined, whereas the East Fork Cranberry River valley is less confined because it is formed in sandy glacial outwash deposits with abundant springs (fig. 13A). The flood-plain deposits at site 41 are variable, but generally contain $0.5-2.0 \mathrm{ft}$ of muck (silt/clay rich in organic matter with a high water content) or organic-rich loam over sand, sand and gravel, or an occasional clay deposit (fig. 19B). The flood-plain surface at site 41 does not have any

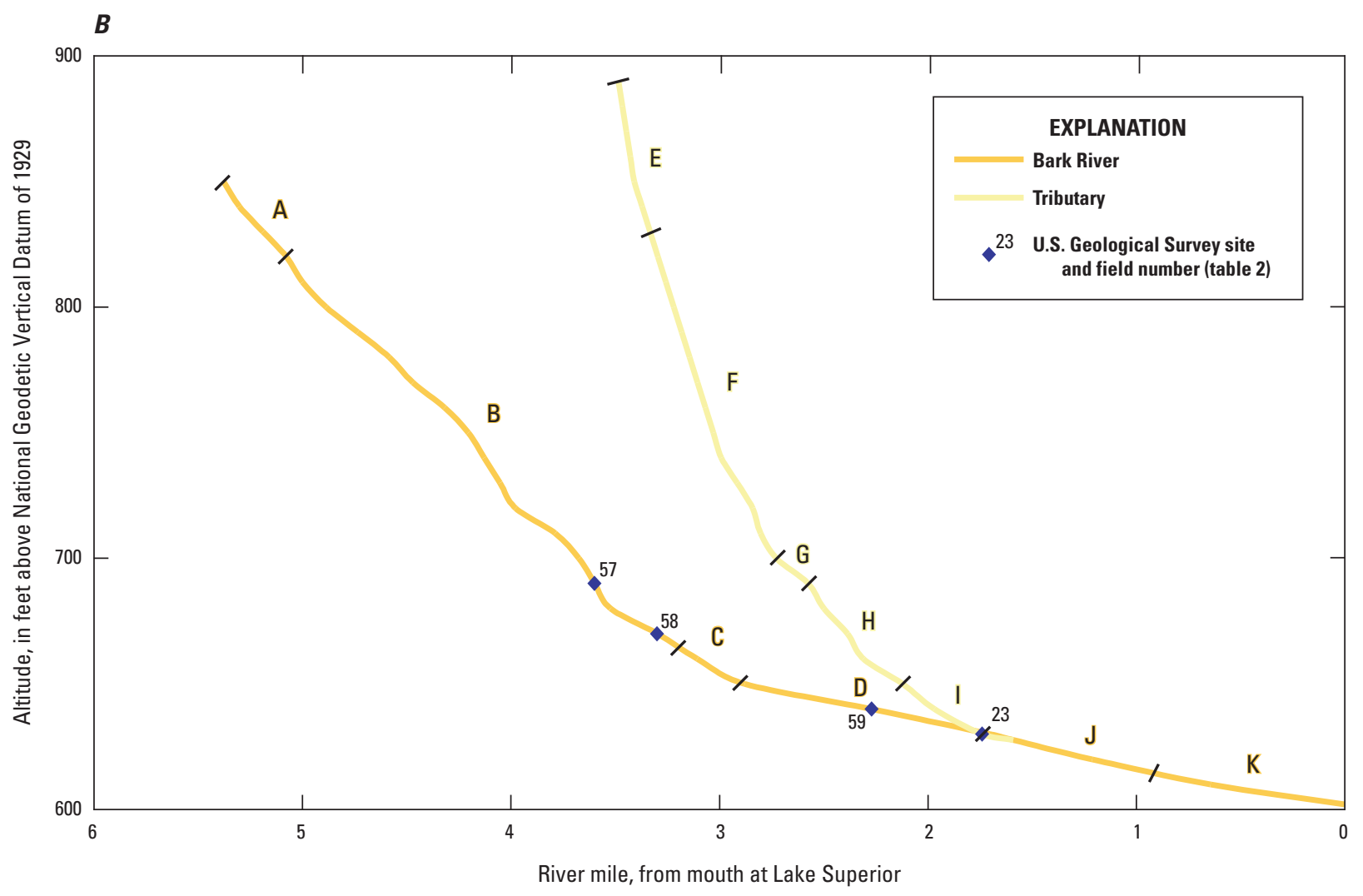

Figure 14. Bark River $A$, map, and $B$, longitudinal profile.-Continued 


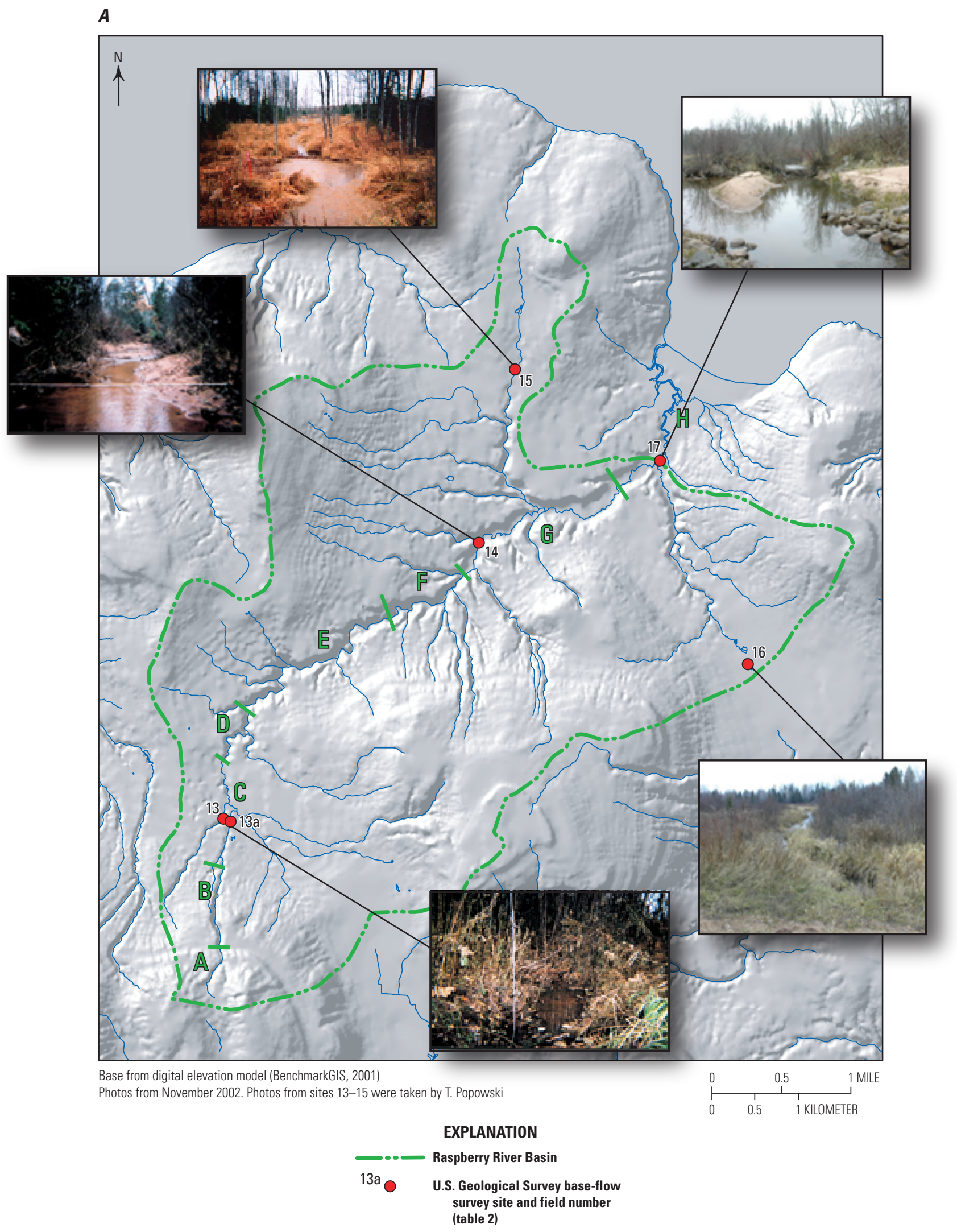

Figure 15. Raspberry River $A$, map, and $B$, longitudinal profile. 
overbank sand sedimentation, LWD is common on the flood plain and channel, and the channel appears to be laterally and vertically stable (reach C). In contrast, the channel at site 63 (reach B) appears to be downcutting, and widening and bank erosion are common.

Continuing downstream, slopes remain steep (fig. 13B) and channels become unstable with evidence of downcutting and incision, widening, and bank erosion (reach $\mathrm{D}$ on the East Fork, reach G on the East Branch, reach L on the South Branch) (fig. 13A, table 7). Valleys are confined. Between about 730 and 760 feet, the valleys are confined, but there is some evidence of the beginnings of a flood plain. Channels show evidence of widening, bank erosion, terrace and bluff erosion, lateral migration, overbank sand deposition and sandbar formation, and possibly incision (reach $\mathrm{E}$ on the East Fork, reach $\mathrm{H}$ on the East Branch, reach $\mathrm{M}$ on the South Branch. Inter-Fluve, Inc. and Graber (2003) noted an abandoned channel that was $1-2 \mathrm{ft}$ higher than the 2003 channel. This reach appears to be highly unstable (laterally and possibly vertically). Evidence of beaver activity (old beaver dams) also is common.
Downstream of about $730 \mathrm{ft}$ on the East Fork (reach I), valleys widen, but the meander pattern is entrenched (fig. 13A). Terrace and bluff erosion, bank erosion, channel widening, and overbank sedimentation are common features.

Reach J on the East Fork (695-660 ft) has less evidence for lateral migration and bank erosion than reach I, and valley development and stream meandering changes from entrenched to somewhat alluvial. The modern channel is vertically stable in this reach, based on data from core 46-4 from an old abandoned channel (predates maps and GLO survey notes (figs. 20A-B). The gravel layer on top of clay in core $46-4$ at $689.5 \mathrm{ft}$ is an older channel bottom (fig. 20B). The modern channel bottom is at an altitude of approximately $690 \mathrm{ft}$. The relict channel is filled with sand, probably from the same flood that caused it to be cut off. Cores 46-5, 46-8, 46-9, and 46-12 had recent fine-sand deposition at the surface with no forest litter; this sand was presumably deposited during the large flood in 2001. [A landowner indicated that there had also been a large flood in 1996 that seemed worse than the 2001 flood, but the Sioux River crest-stage gaging station did not record a large flood in 1996 (fig. 9)]. Multiple layers of fine sand,

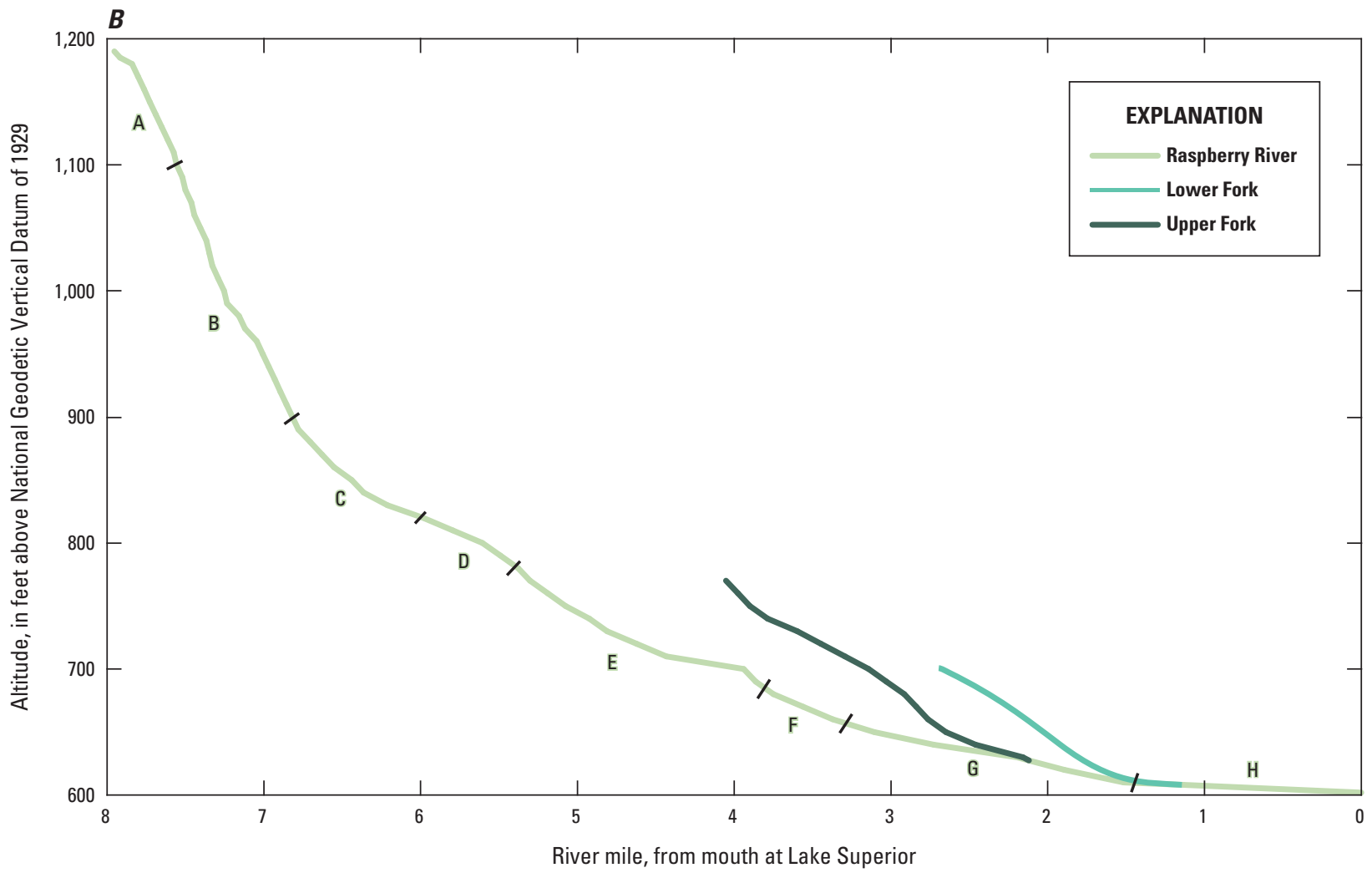

Figure 15. Raspberry River $A$, map, and $B$, longitudinal profile.-Continued 


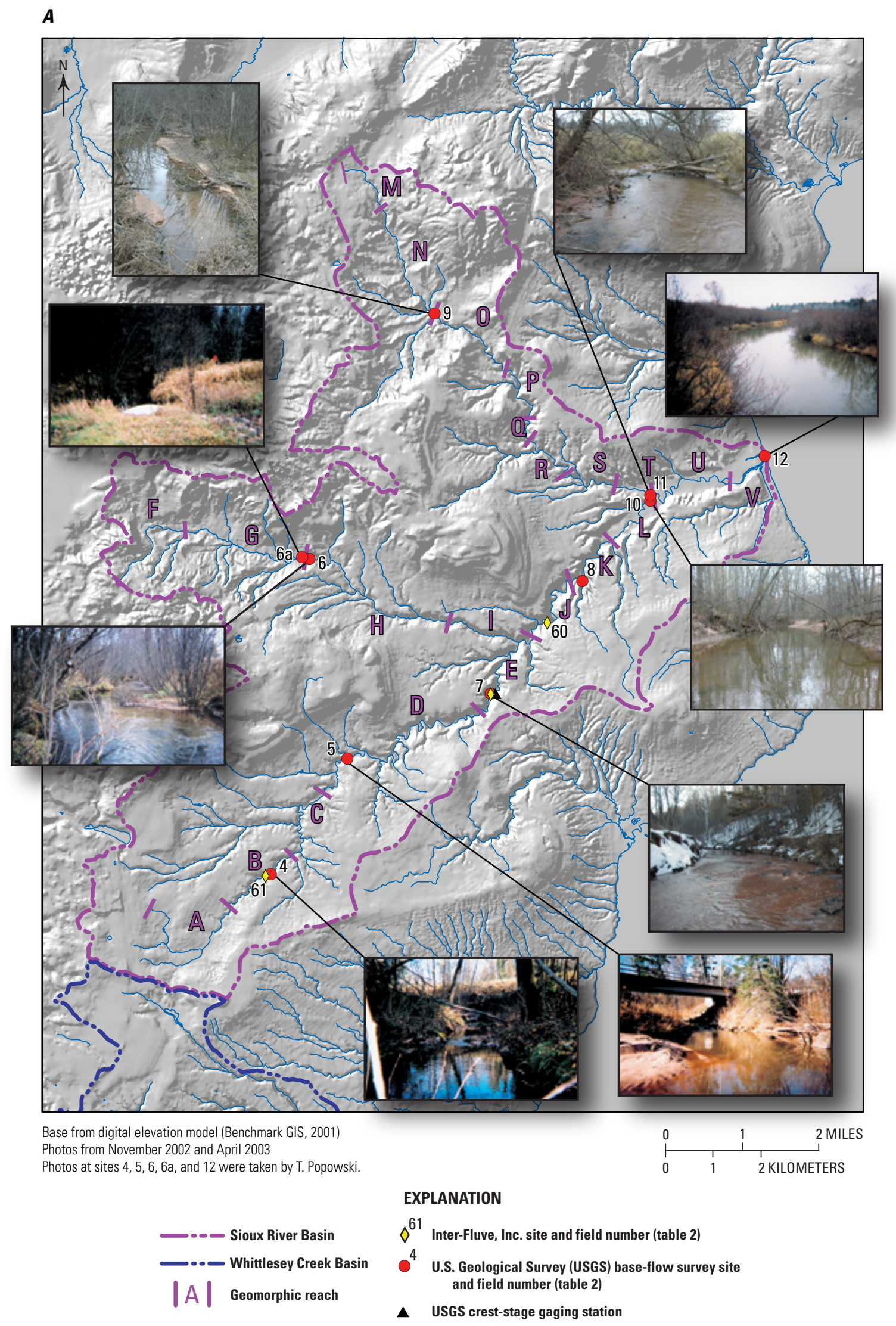

Figure 16. Sioux River $A$, map, and $B$, longitudinal profile. 
organic-rich loam, and buried A horizons in the flood-plain cores indicate that episodic overbank sedimentation was common during small and large floods in this reach.

The South Branch (reach M) appears to be a major contributor of sediment and runoff to the Cranberry River compared to the East Fork. The South Branch watershed is almost entirely clay, and slopes are steep (figs. 7 and 13B). Geomorphic processes in reach $\mathrm{M}$ include bank erosion, channel widening, lateral migration, and overbank sedimentation. Stream cuts into terraces and sand bars also are common.

Reach N on the Cranberry River (660-640 ft) downstream of the confluence of the South Branch and East Fork Cranberry River is unstable (table 7). Several points of valley constriction are located along reaches $\mathrm{N}$ and $\mathrm{O}$, with the one at $650 \mathrm{ft}$ being the most pronounced on almost all Bayfield streams. Bedrock outcrops are common from about 630 to $650 \mathrm{ft}$ on nearby streams such as the South Fork Fish Creek, Bad River, White River, and the Sioux River, and as described earlier, longitudinal profiles for most of the streams have a step-like feature in this altitude range, whether or not bedrock crops out in the channel. This suggests that valley narrowing and steep slopes may be related to postglacial lake shorelines (fig. 21). Figure 21 illustrates how an episodic drop in lake level, with some time period of stable water levels between drops, may cause the formation of a steep stream reach and corresponding narrow valley. Regardless of the cause, this geologic feature seems to be related to unstable channels. As the valley widens downstream, overbank sedimentation is common as well as bank erosion, lateral migration, widening, and sand-bar formation.

Downstream in reach O on the Cranberry River (640 to $615 \mathrm{ft}$ ), bank heights are lower, and fewer terrace cuts are present than in reach N. At site 50, core data indicate evidence of overbank sedimentation (about $4 \mathrm{ft}$ or more during the last 100 years) (fig. 22). The area near site 50 was inundated because of a landslide in 1975 about $500 \mathrm{ft}$ downstream of this site; the landslide temporarily backed up water for days (fig. 22A) (Scott Anderholm, U.S. Geological Survey, written commun., 2004). Trees with buried root crowns are on top of a buried soil, assumed to be a presettlement soil because of its thickness, amount of organic material, and presence of LWD at the top (remnants from logging and log drives) (figs. $22 B$ and 23). The vertical stability of the channel through this reach could not be verified with the core data (deeper cores are

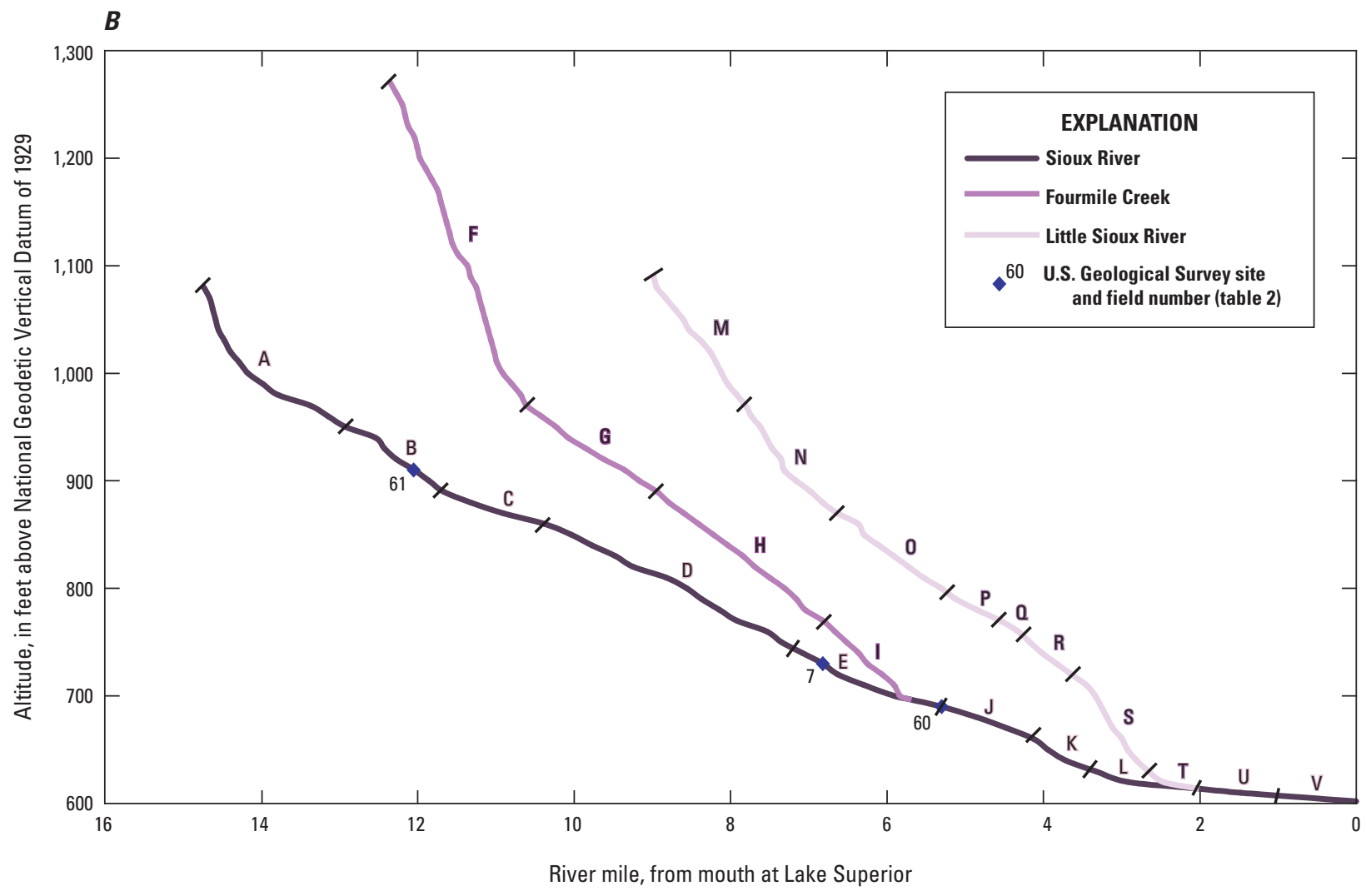

Figure 16. Sioux River $A$, map, and $B$, longitudinal profile.-Continued 


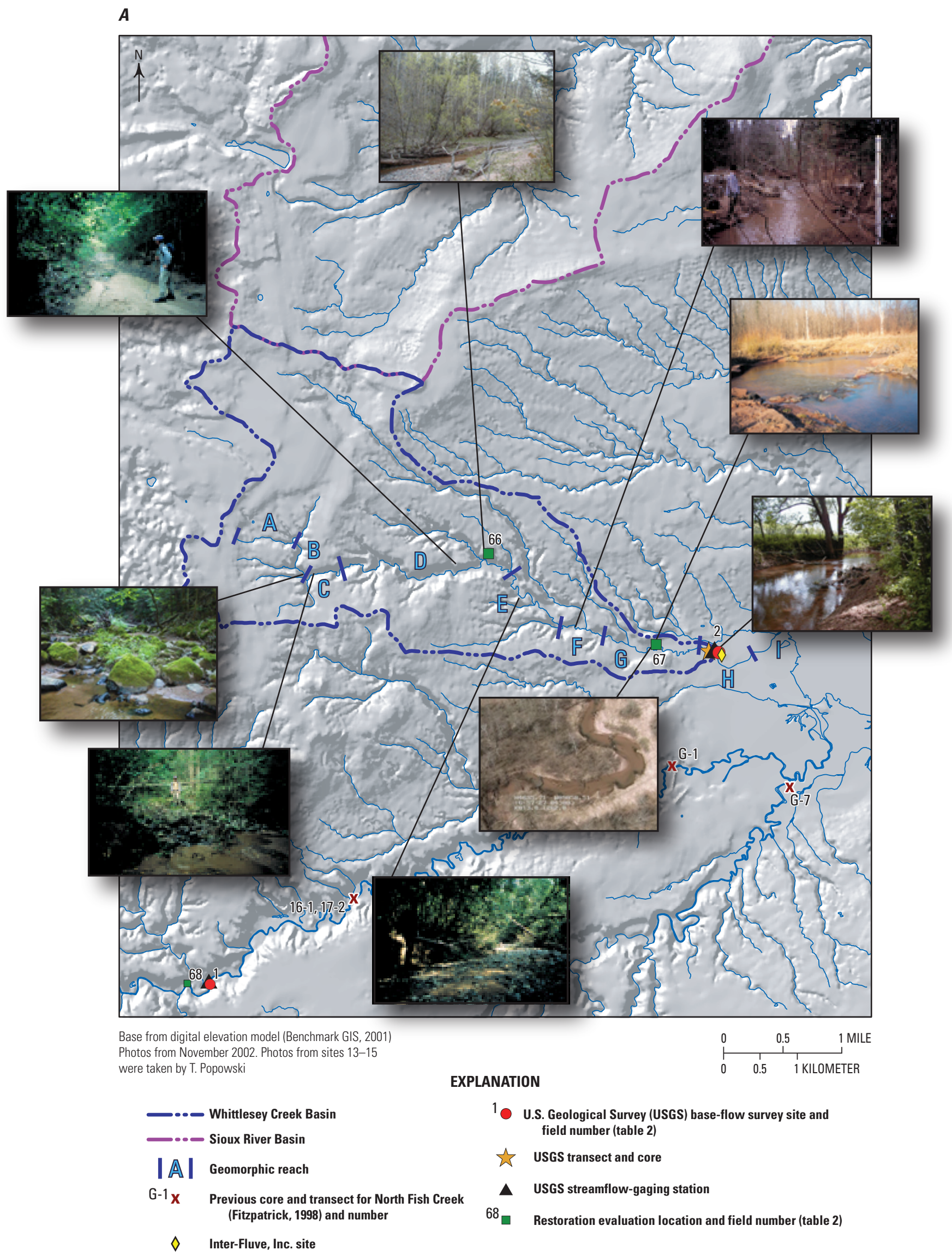

Figure 17. Whittlesey Creek $A$, map, and $B$, longitudinal profile. 
needed), but the high amount of overbank sedimentation and levee formation at site 50 makes the channel look entrenched. Overbank sediment consists of layers of fine sand and organicrich loam (figs. $22 B$ and $C$ ).

Two terrace cuts were described (50-1 and 50-11), one near the landslide and the other upstream near the valley constriction (figs $22 A$ and $D$ ). The downstream terrace cut is about $13 \mathrm{ft}$ above the low-flow water surface. The terrace consists of a medium sand with a well developed A horizon at the surface overlying a boulder zone, with red clay near the low-flow water surface. Upstream at 50-11, the terrace appears to be a remnant of the top part of an old landslide because red and gray clay are over sand and organic-rich loam deposits. A gravel/boulder zone is present in both terrace cuts at about $6 \mathrm{ft}$ above the modern channel bottom. This zone indicates incision, most likely during the early Holocene when lake levels were at their lowest $(9,000 \mathrm{yr} \mathrm{BP})$.

At about $615 \mathrm{ft}$, the Cranberry River valley widens and the stream-meandering pattern becomes alluvial and continues to be alluvial downstream to the mouth (reaches P and Q) (fig. 13). Banks are higher and more prone to erosion and sand bars are more prevalent in reach $\mathrm{P}$ than in reach $\mathrm{Q}$. An extensive LWD layer in the abandoned channel at site 30 at $603.5 \mathrm{ft}$ is at an altitude similar to the low-flow water surface in the
2002 channel (fig. 24B). The altitude of the bottom of the 2002 channel is similar to that of the abandoned channel bottom, but levees are up to $10 \mathrm{ft}$ above the channel bottom. Higher banks through formation of levees lead to the potential for avulsion and bank erosion. Downstream, cores 30-6, 30-7, and 30-8 indicate that historical alluvium consists of about $3-4 \mathrm{ft}$ of fine sand and organic-rich loam and clay layers (fig. 24B). Core 30-7 has sand at the surface, probably from the 2001 flood. Natural levee formation along banks at site 30-5 is less pronounced than at site $30-1$, and banks are about $4 \mathrm{ft} \mathrm{high}$. Gravel at the base of core 30-8 possibly indicates an old channel bottom.

Sediment cores previously collected along North Fish Creek indicate similar geomorphic conditions to the Cranberry River (Fitzpatrick, 1998) (figs. 25A-C). Lateral instability, overbank deposition, and unknown vertical stability are evident in North Fish Creek cores 16-1 and 17-2 at an altitude of about 650 feet, similar to site 50 on the Cranberry River (fig. 25A). For North Fish Creek, approximately 6 to $7 \mathrm{ft}$ of alluvium overlies buried root crowns and abundant LWD. A gravel lag deposit near the base of the banks at the North Fish and Cranberry River sites suggests that the channel-bed altitude has been relatively constant. Regardless of whether these channels are aggrading or incising, they function as

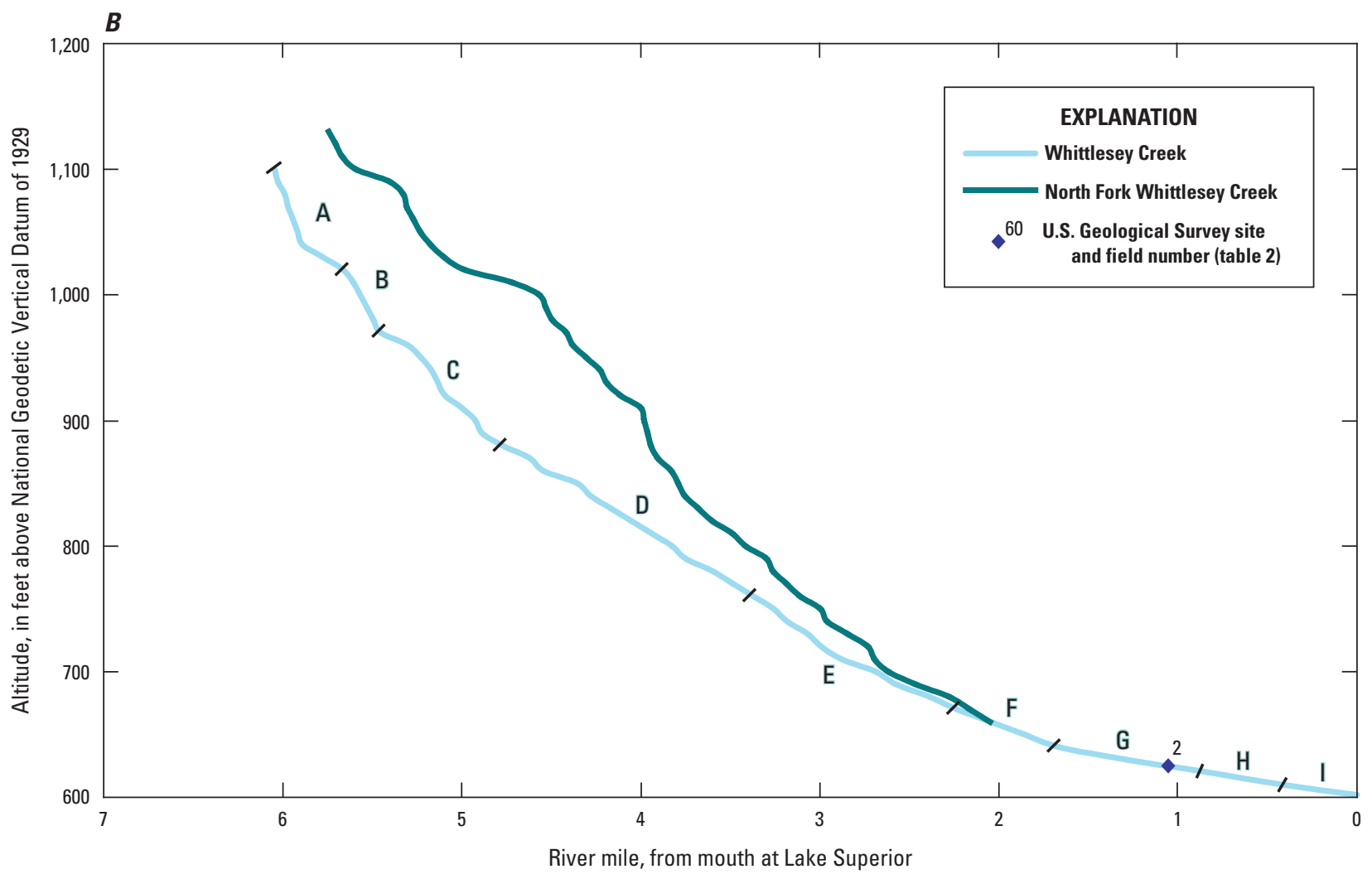

Figure 17. Whittlesey Creek $A$, map, and $B$, longitudinal profile.-Continued 
Table 7. Summary of geomorphic characteristics and processes by altitude for five Bayfield Peninsula streams, Wisconsin. Reaches are shown on figs. 13-17.

[ft, feet; mi, mile. Stream: R., River; us, upstream; Cr., Creek; ds, downstream; S., South; Br., Branch. Valley type: U, unconfined; C, confined; A, alluvial; E, entrenched. Channel stability: S, stable; $\mathrm{U}$, unstable. Geomorphic processes: X, geomorphic characteristic or process is present. Comments: LWD, large woody debris.]

\begin{tabular}{|c|c|c|c|c|c|c|c|c|c|c|c|c|c|c|c|}
\hline \multirow[b]{2}{*}{ 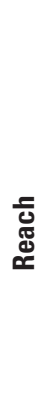 } & \multirow[b]{2}{*}{ 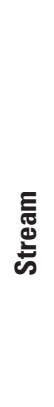 } & \multirow[b]{2}{*}{ 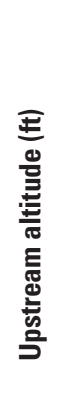 } & \multirow[b]{2}{*}{ 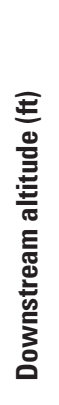 } & \multirow[b]{2}{*}{ 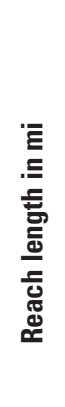 } & \multirow[b]{2}{*}{ 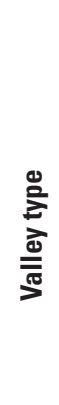 } & \multirow[b]{2}{*}{ 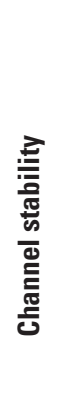 } & \multicolumn{8}{|c|}{ Geomorphic processes } & \multirow[b]{2}{*}{ 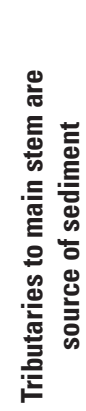 } \\
\hline & & & & & & & 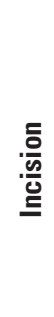 & $\begin{array}{l}\text { 흥 } \\
\text { 잏 } \\
\text { 들 } \\
\text { Ф }\end{array}$ & 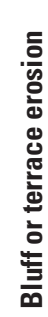 & 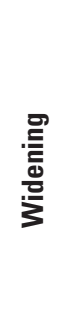 & 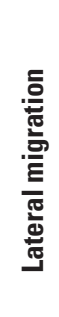 & 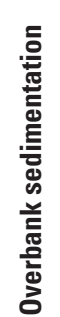 & 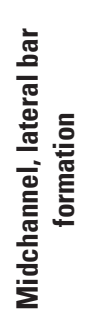 & 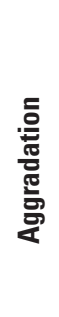 & \\
\hline
\end{tabular}

H East Branch of the East Fork Cranberry River

Cranberry River Basin

\begin{tabular}{|c|c|c|c|c|c|c|c|c|c|c|c|c|c|c|c|}
\hline \multicolumn{16}{|c|}{$\mathrm{G}$} \\
\hline A & Lenawee Creek & 1,120 & 1,070 & 1.6 & $\mathrm{U} / \mathrm{C}$ & $\mathrm{S}$ & & & & & & & & & $\begin{array}{l}\text { Runoff contributes to downstream } \\
\text { problems but no erosion in this } \\
\text { reach, no channel on } 1852 \text { map. }\end{array}$ \\
\hline B & Lenawee Creek & 1,070 & 817 & 1.8 & $\mathrm{C}$ & $\mathrm{U}$ & $\mathrm{X}$ & $\mathrm{X}$ & & $\mathrm{X}$ & & & & $\mathrm{X}$ & Headcutting at about $1,070 \mathrm{ft}$. \\
\hline $\mathrm{C}$ & $\begin{array}{c}\text { East Fork Cranberry R. } \\
\text { us of Lenawee Cr. }\end{array}$ & 1,115 & 817 & 2.7 & $\mathrm{U} / \mathrm{C} / \mathrm{A}$ & $\mathrm{S}$ & & & & & & & & & $\begin{array}{l}\text { Watershed sand/gravel deposits } \\
\text { cause low runoff rates, no log } \\
\text { drives upstream of confluence. }\end{array}$ \\
\hline $\mathrm{D}$ & $\begin{array}{l}\text { East Fork Cranberry R. } \\
\text { ds of Lenawee Cr. }\end{array}$ & 817 & 770 & 0.8 & $\mathrm{C}$ & $\mathrm{U}$ ? & $?$ & $\mathrm{X}$ & & $\mathrm{X}$ & & & & $\mathrm{X}$ & $\begin{array}{l}2003 \text { channel } 8 \mathrm{ft} \text { wider than } 1852 \\
\text { channel. }\end{array}$ \\
\hline E & $\begin{array}{l}\text { East Fork Cranberry R. } \\
\text { us of the East Branch }\end{array}$ & 770 & 720 & 0.9 & $\mathrm{C}$ & $\mathrm{U}$ & $\mathrm{X}$ & $\mathrm{X}$ & $\mathrm{X}$ & $\mathrm{X}$ & $\mathrm{X}$ & $\mathrm{X}$ & $\mathrm{X}$ & $\mathrm{X}$ & $\begin{array}{l}2003 \text { channel } 5 \mathrm{ft} \text { wider than } 1852 \\
\text { channel, very unstable reach. }\end{array}$ \\
\hline $\mathrm{F}$ & $\begin{array}{l}\text { East Branch of the East } \\
\text { Fork Cranberry River }\end{array}$ & 1,080 & 830 & 3.5 & $\mathrm{U} / \mathrm{C}$ & $\mathrm{S}$ & & & & & & & & & $\begin{array}{l}\text { No data upstream of } 830 \mathrm{ft} \text { to } \\
\text { confirm stability but looks stable } \\
\text { at } 830 \mathrm{ft} \text {., contributes runoff but } \\
\text { no sediment. }\end{array}$ \\
\hline G & $\begin{array}{l}\text { East Branch of the East } \\
\text { Fork Cranberry River }\end{array}$ & 830 & 780 & 0.7 & $\mathrm{C}$ & $\mathrm{U}$ ? & $\mathrm{X}$ & & & & & & & $?$ & $\begin{array}{l}\text { Helicopter video shows small chan- } \\
\text { nel, no noticeable bank erosion, } \\
\text { possible incision. }\end{array}$ \\
\hline $\mathrm{H}$ & $\begin{array}{l}\text { East Branch of the East } \\
\text { Fork Cranberry River }\end{array}$ & 780 & 720 & 1.2 & $\mathrm{C}$ & $\mathrm{U}$ & $X$ & $\mathrm{X}$ & $\mathrm{X}$ & $\mathrm{X}$ & $\mathrm{X}$ & $X$ & $\mathrm{X}$ & $\mathrm{X}$ & $\begin{array}{l}\text { Old beaver dams, stream looks } \\
\text { highly unstable from helicopter } \\
\text { video, } 2003 \text { channel } 7 \mathrm{ft} \text { wider } \\
\text { than } 1852 \text { channel. }\end{array}$ \\
\hline I & $\begin{array}{l}\text { East Fork Cranberry R. } \\
\text { ds of the East Branch }\end{array}$ & 720 & 695 & 1.2 & E & $\mathrm{U}$ & & $\mathrm{X}$ & $\mathrm{X}$ & $X$ & $X$ & $X$ & & $X$ & $\begin{array}{l}\text { Bluff and terrace erosion, } 2003 \\
\text { channel } 6 \mathrm{ft} \text { wider than } 1852 \\
\text { channel. }\end{array}$ \\
\hline
\end{tabular}


Table 7. Summary of geomorphic characteristics and processes by altitude for five Bayfield Peninsula streams, Wisconsin. Reaches are shown on figs. $13-17$.

[ft, feet; mi, mile. Stream: R., River; us, upstream; Cr., Creek; ds, downstream; S., South; Br., Branch. Valley type: U, unconfined; C, confined; A, alluvial; E, entrenched. Channel stability: S, stable; $\mathrm{U}$, unstable. Geomorphic processes: X, geomorphic characteristic or process is present. Comments: LWD, large woody debris.]

\begin{tabular}{|c|c|c|c|c|c|c|c|c|c|c|c|c|c|c|c|}
\hline \multirow[b]{2}{*}{ 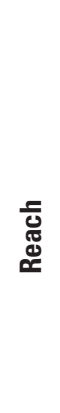 } & \multirow[b]{2}{*}{ 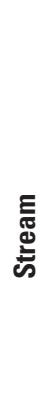 } & \multirow[b]{2}{*}{ 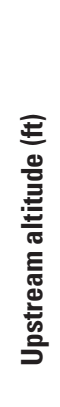 } & \multirow[b]{2}{*}{ 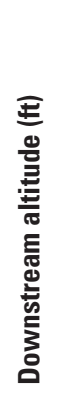 } & \multirow[b]{2}{*}{ 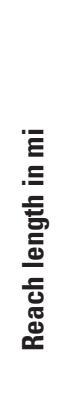 } & \multirow[b]{2}{*}{ 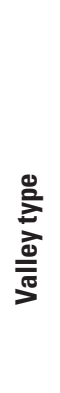 } & \multirow[b]{2}{*}{ 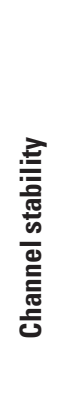 } & \multicolumn{8}{|c|}{ Geomorphic processes } & \multirow[b]{2}{*}{ 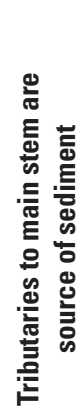 } \\
\hline & & & & & & & 흐모을 & 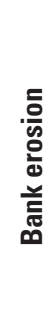 & 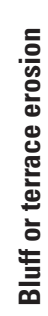 & 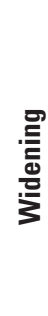 & 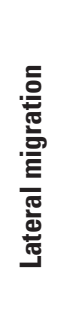 & 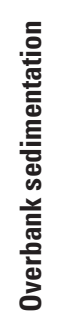 & 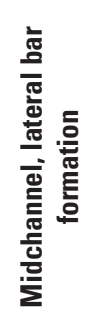 & 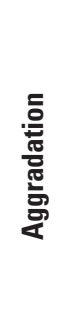 & \\
\hline
\end{tabular}

\begin{tabular}{|c|c|c|c|c|c|c|c|c|c|c|c|c|c|c|c|c|}
\hline \multicolumn{17}{|c|}{ Cranberry River Basin-Continued } \\
\hline $\mathrm{J}$ & $\begin{array}{l}\text { East Fork Cranberry } \\
\text { R. us of the South } \\
\text { Branch }\end{array}$ & 695 & 660 & 1.1 & $\mathrm{E} / \mathrm{A}$ & $\mathrm{U}$ & & $\mathrm{X}$ & $\mathrm{X}$ & $\mathrm{X}$ & & $\mathrm{X}$ & & & $\mathrm{X}$ & $\begin{array}{l}\text { Reach is somewhat more stable } \\
\text { than upstream or downstream; } \\
\text { mobile gravel bars. }\end{array}$ \\
\hline K & S. Br. Cranberry River & 1,080 & 780 & 2.5 & $\mathrm{U} / \mathrm{C}$ & $\mathrm{S}$ & & & & & & & & & & Contributes runoff but no sediment. \\
\hline $\mathrm{L}$ & S. Br. Cranberry River & 780 & 730 & 0.6 & $\mathrm{C}$ & $\mathrm{U}$ & $\mathrm{X}$ & $\mathrm{X}$ & & & & & & & $?$ & $\begin{array}{l}\text { Helicopter video indicates moder- } \\
\text { ate incision. }\end{array}$ \\
\hline M & S. Br. Cranberry River & 730 & 660 & 1.1 & $\mathrm{C} / \mathrm{E}$ & $\mathrm{U}$ & & $\mathrm{X}$ & $\mathrm{X}$ & $\mathrm{X}$ & $\mathrm{X}$ & $?$ & $\mathrm{X}$ & & $\mathrm{X}$ & $\begin{array}{l}\text { Stream looks very unstable from } \\
\text { helicopter video, terrace/bank } \\
\text { erosion very common, old } \\
\text { beaver dams, very common sand } \\
\text { deposition, clayey deposits in } \\
\text { watershed. }\end{array}$ \\
\hline $\mathrm{N}$ & Cranberry River & 660 & 640 & 1.2 & $\mathrm{E}$ & $\mathrm{U}$ & $?$ & $\mathrm{X}$ & $\mathrm{X}$ & $\mathrm{X}$ & $\mathrm{X}$ & $\mathrm{X}$ & $X$ & & $\mathrm{X}$ & $\begin{array}{l}\text { Bank and terrace erosion common; } \\
\text { cut banks along bluffs appear } \\
\text { healed over; } 2003 \text { channel } 4 \mathrm{ft} \\
\text { wider than } 1852 \text { channel. }\end{array}$ \\
\hline $\mathrm{O}$ & Cranberry River & 640 & 615 & 1.6 & $\mathrm{E}$ & $\mathrm{U}$ & & $\mathrm{X}$ & $?$ & $\mathrm{X}$ & $\mathrm{X}$ & $\mathrm{X}$ & $\mathrm{X}$ & & $\mathrm{X}$ & $\begin{array}{l}\text { Bluff failure blocked off creek for a } \\
\text { few days in mid 1970s, boulder } \\
\text { zones in channel common. }\end{array}$ \\
\hline $\mathrm{P}$ & Cranberry River & 615 & 605 & 1.4 & $\mathrm{~A} / \mathrm{E}$ & $\mathrm{U}$ & & $\mathrm{X}$ & & & $\mathrm{X}$ & $\mathrm{X}$ & $\mathrm{X}$ & & & $\begin{array}{l}\text { Very large log jam at } 610 \mathrm{ft} \text { at tran- } \\
\text { sition to lower slope on longi- } \\
\text { tudinal profile; } 2003 \text { channel } 10 \\
\mathrm{ft} \text { narrower than } 1852 \text { channel; } \\
\text { historical aggradation? }\end{array}$ \\
\hline Q & Cranberry River & 605 & 602 & 0.6 & A & $\mathrm{S} ?$ & & & & & $\mathrm{X}$ & $\mathrm{X}$ & & $?$ & & $\begin{array}{l}\text { Banks are low, wetland in flood } \\
\text { plain; historical aggradation. }\end{array}$ \\
\hline & Cranberry River total & & & 24.5 & & & & 5.2 & 9.9 & 6.7 & 10.9 & 9.2 & 10.3 & 7.4 & 0.0 & \\
\hline
\end{tabular}


Table 7. Summary of geomorphic characteristics and processes by altitude for five Bayfield Peninsula streams, Wisconsin. Reaches are shown on figs. 13-17.

[ft, feet; mi, mile. Stream: R., River; us, upstream; Cr., Creek; ds, downstream; S., South; Br., Branch. Valley type: U, unconfined; C, confined; A, alluvial; E, entrenched. Channel stability: S, stable; $\mathrm{U}$, unstable. Geomorphic processes: $\mathrm{X}$, geomorphic characteristic or process is present. Comments: LWD, large woody debris.]

\begin{tabular}{|c|c|c|c|c|c|c|c|c|c|c|c|c|c|c|c|c|}
\hline \multirow[b]{2}{*}{ 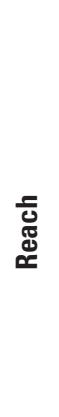 } & \multirow[b]{2}{*}{ 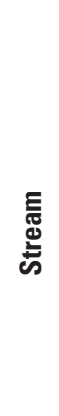 } & \multirow[b]{2}{*}{ 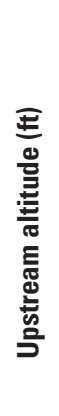 } & \multirow[b]{2}{*}{ 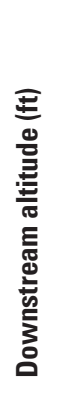 } & \multirow[b]{2}{*}{ 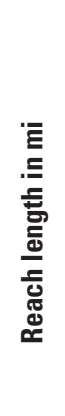 } & \multirow[b]{2}{*}{ 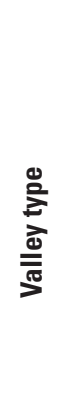 } & \multirow[b]{2}{*}{ 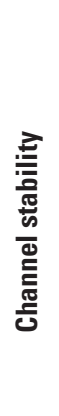 } & \multicolumn{8}{|c|}{ Geomorphic processes } & \multirow[b]{2}{*}{ 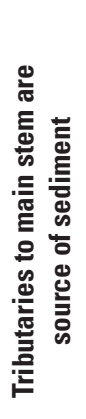 } & \multirow[b]{2}{*}{ 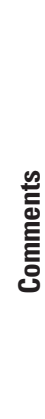 } \\
\hline & & & & & & & 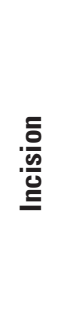 & 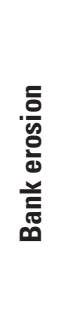 & 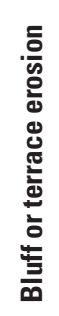 & 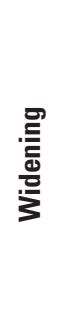 & 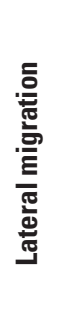 & 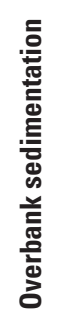 & 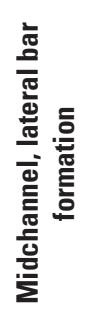 & 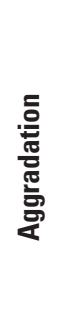 & & \\
\hline
\end{tabular}

\begin{tabular}{|c|c|c|c|c|c|c|c|c|c|c|c|c|c|c|c|c|}
\hline \multicolumn{17}{|c|}{ Bark River } \\
\hline A & Bark River & 850 & $820 ?$ & 0.3 & $\mathrm{U} / \mathrm{C}$ & S? & $?$ & & & & & & & & & $\begin{array}{l}\text { Stream looks stable on helicopter } \\
\text { flyover, some evidence of head- } \\
\text { cutting in Inter-Fluve, Inc. and } \\
\text { Graber (2003). }\end{array}$ \\
\hline B & Bark River & $820 ?$ & 665 & 1.9 & $\mathrm{C}$ & $\mathrm{U}$ & $\mathrm{X}$ & $\mathrm{X}$ & $\mathrm{X}$ & & $\mathrm{X}$ & $?$ & $\mathrm{X}$ & & $\mathrm{X}$ & $\begin{array}{l}\text { Inter-Fluve, Inc. and Graber (2003) } \\
\text { observed bluff and terrace ero- } \\
\text { sion from } 700 \text { to } 650 \mathrm{ft} .\end{array}$ \\
\hline $\mathrm{C}$ & Bark River & 665 & 650 & 3.3 & $\mathrm{E}$ & $\mathrm{S} ?$ & & & $\mathrm{X}$ & & & & & & & $\begin{array}{l}\text { Small bluff erosion at } 655 \mathrm{ft} \text { (nar- } \\
\text { row valley), mainly transport }\end{array}$ \\
\hline $\mathrm{D}$ & Bark River & 650 & 630 & 1.2 & $\mathrm{E}$ & $\mathrm{U}$ & & $?$ & & $\mathrm{X}$ & $\mathrm{X}$ & $\mathrm{X}$ & $\mathrm{X}$ & $\mathrm{X}$ & & Heavy beaver activity. \\
\hline $\mathrm{E}$ & Bark River tributary & 890 & 830 & 0.2 & $\mathrm{U} / \mathrm{C}$ & $\mathrm{S} ?$ & & & & & & & & & & \\
\hline $\mathrm{F}$ & Bark River tributary & 830 & 700 & 0.6 & $\mathrm{C}$ & $\mathrm{U}$ & $\mathrm{X}$ & $?$ & & & & & & & $\mathrm{X}$ & \\
\hline G & Bark River tributary & 700 & 690 & 0.2 & $\mathrm{E}$ & $?$ & & & & & & & & & & \\
\hline $\mathrm{H}$ & Bark River tributary & 690 & 650 & 0.3 & $\mathrm{C} / \mathrm{E}$ & $\mathrm{U}$ & & $\mathrm{X}$ & & $\mathrm{X}$ & $\mathrm{X}$ & $?$ & $\mathrm{X}$ & $?$ & & Beaver activity. \\
\hline I & Bark River tributary & 650 & 630 & 0.7 & $\mathrm{E}$ & $\mathrm{U}$ & & $\mathrm{X}$ & & & $\mathrm{X}$ & & $\mathrm{X}$ & & & Beaver activity. \\
\hline $\mathrm{J}$ & Bark River & 630 & 615 & 0.8 & $\mathrm{E} / \mathrm{A}$ & $\mathrm{U}$ ? & & $\mathrm{X}$ & & & $\mathrm{X}$ & & & $\mathrm{X}$ & & Beaver activity. \\
\hline \multirow[t]{2}{*}{ K } & Bark River & 615 & 602 & 0.9 & A & $\mathrm{S} ?$ & & & & & & & & $\mathrm{X}$ & & \\
\hline & Bark River total miles & & & 10.4 & & & & 2.5 & 3.7 & 5.2 & 1.5 & 4.9 & 1.2 & 4.1 & 2.9 & \\
\hline
\end{tabular}

\begin{tabular}{|c|c|c|c|c|c|c|c|c|c|c|c|c|c|}
\hline \multicolumn{14}{|c|}{ Raspberry River } \\
\hline A & Raspberry River & 1,190 & 1,100 & 0.4 & $\mathrm{U}$ & $\mathrm{S}$ & & & & & & & Contributes runoff but no sediment. \\
\hline $\mathrm{B}$ & Raspberry River & 1,100 & 900 & 0.7 & $\mathrm{C}$ & $\mathrm{U} ?$ & $\mathrm{X}$ ? & & & & & & \\
\hline $\mathrm{C}$ & Raspberry River & 900 & 820 & 0.8 & $\mathrm{U}$ & $\mathrm{U} ?$ & & $\mathrm{X}$ & $\mathrm{X}$ & $\mathrm{X}$ ? & & $\mathrm{X}$ & Beaver activity common. \\
\hline $\mathrm{D}$ & Raspberry River & 820 & 780 & 0.6 & $\mathrm{C}$ & $\mathrm{U}$ & $\mathrm{X}$ & $\mathrm{X}$ & & & $\mathrm{X}$ & $\mathrm{X}$ & \\
\hline $\mathrm{E}$ & Raspberry River & 780 & 690 & 1.5 & $\mathrm{C} / \mathrm{E}$ & $\mathrm{U}$ & $X ?$ & $\mathrm{X}$ & $\mathrm{X}$ & $X ?$ & $\mathrm{X}$ & $\mathrm{X}$ & Bluff erosion on 2000 air photos. \\
\hline
\end{tabular}


Table 7. Summary of geomorphic characteristics and processes by altitude for five Bayfield Peninsula streams, Wisconsin. Reaches are shown on figs. 13-17.

[ft, feet; mi, mile. Stream: R., River; us, upstream; Cr., Creek; ds, downstream; S., South; Br., Branch. Valley type: U, unconfined; C, confined; A, alluvial; E, entrenched. Channel stability: S, stable; $\mathrm{U}$, unstable. Geomorphic processes: X, geomorphic characteristic or process is present. Comments: LWD, large woody debris.]

\begin{tabular}{|c|c|c|c|c|c|c|c|c|c|c|c|c|c|c|c|c|}
\hline \multirow[b]{2}{*}{ 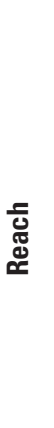 } & \multirow[b]{2}{*}{ 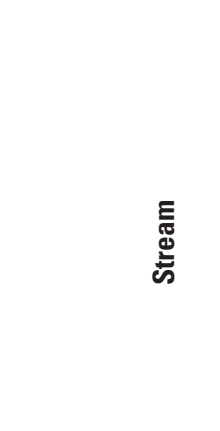 } & \multirow[b]{2}{*}{ 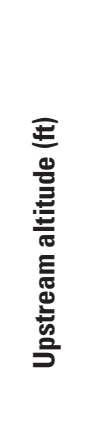 } & \multirow[b]{2}{*}{ 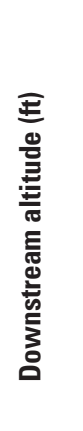 } & \multirow[b]{2}{*}{ 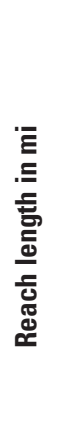 } & \multirow[b]{2}{*}{ 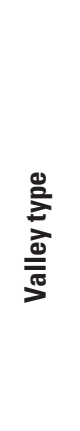 } & \multirow[b]{2}{*}{ 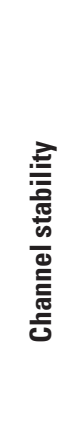 } & \multicolumn{8}{|c|}{ Geomorphic processes } & \multirow[b]{2}{*}{ 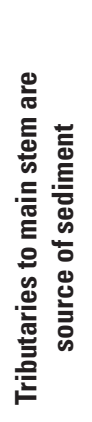 } & \multirow[b]{2}{*}{ 畩 } \\
\hline & & & & & & & :흘 & 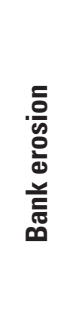 & 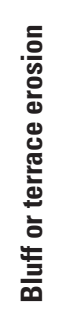 & $\frac{.00}{3}$ & 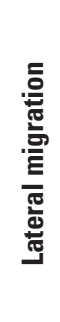 & 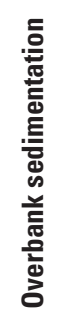 & 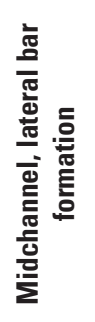 & 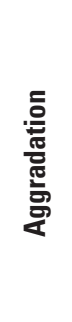 & & \\
\hline \multicolumn{17}{|c|}{ Raspberry River-Continued } \\
\hline $\mathrm{F}$ & Raspberry River & 690 & 655 & 0.6 & $\mathrm{E}$ & $\mathrm{U}$ & & $\mathrm{X}$ & & $\mathrm{X} ?$ & $\mathrm{X}$ & $\mathrm{X}$ & $\mathrm{X}$ & & $\mathrm{X}$ & \\
\hline G & Raspberry River & 655 & 610 & 1.7 & A & $\mathrm{U}$ & & $\mathrm{X}$ & & $\mathrm{X}$ & $\mathrm{X}$ & $\mathrm{X}$ & $\mathrm{X}$ & & & $\begin{array}{l}\text { Depositional bars common in } 2000 \\
\text { air photos. }\end{array}$ \\
\hline $\mathrm{H}$ & Raspberry River & 610 & 602 & 1.5 & A & $\mathrm{U}$ & & & & & & $\mathrm{X}$ ? & & $\mathrm{X} ?$ & & $\begin{array}{l}\text { Wetland in flood plain, common } \\
\text { beaver activity. }\end{array}$ \\
\hline & Raspberry River & & & 7.8 & & & & 2.8 & 5.2 & 1.5 & 3.1 & 2.3 & 6.1 & 4.4 & 1.5 & \\
\hline \multicolumn{17}{|c|}{ Sioux River } \\
\hline A & Sioux River & 1,080 & 950 & 1.8 & $\mathrm{U}$ & S? & $?$ & & & & & & & & & Provides runoff but no sediment \\
\hline $\mathrm{B}$ & Sioux River & 950 & 890 & 1.2 & $\mathrm{U} / \mathrm{C}$ & $\mathrm{U}$ & $\mathrm{X}$ & $\mathrm{X}$ ? & & & & & & & & $\begin{array}{l}\text { Beaver activity common in upper } \\
\text { part. }\end{array}$ \\
\hline $\mathrm{C}$ & Sioux River & 890 & 860 & 1.3 & $\mathrm{E} / \mathrm{A}$ & $\mathrm{U}$ & $?$ & $\mathrm{X}$ & $\mathrm{X}$ & & $\mathrm{X}$ & & & & $?$ & \\
\hline $\mathrm{D}$ & Sioux River & 860 & 745 & 3.2 & $\mathrm{E}$ & $\mathrm{U}$ & $\mathrm{X}$ & $\mathrm{X}$ & $\mathrm{X}$ & $\mathrm{X}$ & $\mathrm{X}$ & $\mathrm{X}$ & $\mathrm{X}$ & & $\mathrm{X}$ & $\begin{array}{l}\text { Bluff erosion common, local ag- } \\
\text { gradation. }\end{array}$ \\
\hline $\mathrm{E}$ & Sioux River & 745 & 690 & 1.9 & $\mathrm{C}$ & $\mathrm{U}$ & $\mathrm{X}$ & $\mathrm{X}$ & $\mathrm{X}$ & & $\mathrm{X}$ & $\mathrm{X}$ & $\mathrm{X}$ & & $\mathrm{X}$ & Eroding bluffs common. \\
\hline $\mathrm{F}$ & Fourmile Creek & 1,270 & 970 & 1.7 & $\mathrm{U}$ & S? & & & & & & & & & & Provides runoff but no sediment. \\
\hline $\mathrm{G}$ & Fourmile Creek & 970 & 890 & 1.7 & $\mathrm{~A}$ & S? & & & & & & & & $\mathrm{X}$ & & Beaver activity common. \\
\hline $\mathrm{H}$ & Fourmile Creek & 890 & 770 & 2.1 & $\mathrm{C}$ & $\mathrm{U} ?$ & & & & & & & & & & $\begin{array}{l}\text { Riparian forest cover thick, can’t } \\
\text { see channel on helicopter video. }\end{array}$ \\
\hline $\mathrm{I}$ & Fourmile Creek & 770 & 700 & 1.1 & $\mathrm{C}$ & $\mathrm{U} / \mathrm{S} ?$ & & $?$ & & $?$ & & & & & & $\begin{array}{l}\text { Possibly bedrock channel, poor vis- } \\
\text { ibility on helicopter video. }\end{array}$ \\
\hline $\mathrm{J}$ & Sioux River & 690 & 660 & 1.2 & $\mathrm{E} / \mathrm{C}$ & $\mathrm{U} / \mathrm{S} ?$ & & $\mathrm{X}$ & $\mathrm{X}$ & $\mathrm{X}$ & & $\mathrm{X}$ & $X$ & & $\mathrm{X}$ & $\begin{array}{l}\text { Confined areas are rocky, some } \\
\text { minor bluff and bank erosion, } \\
\text { downstream part looks stable. }\end{array}$ \\
\hline $\mathrm{K}$ & Sioux River & 660 & 630 & 0.8 & $\mathrm{C}$ & $\mathrm{U} / \mathrm{S} ?$ & & & & $\mathrm{X}$ & & & & & $\mathrm{X}$ & Bedrock channel. \\
\hline
\end{tabular}


Table 7. Summary of geomorphic characteristics and processes by altitude for five Bayfield Peninsula streams, Wisconsin. Reaches are shown on figs. 13-17.

[ft, feet; mi, mile. Stream: R., River; us, upstream; Cr., Creek; ds, downstream; S., South; Br., Branch. Valley type: U, unconfined; C, confined; A, alluvial; E, entrenched. Channel stability: S, stable; $\mathrm{U}$, unstable. Geomorphic processes: $\mathrm{X}$, geomorphic characteristic or process is present. Comments: LWD, large woody debris.]

\begin{tabular}{|c|c|c|c|c|c|c|c|c|c|c|c|c|c|c|c|c|}
\hline \multirow[b]{2}{*}{ 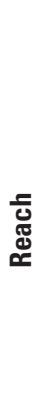 } & \multirow[b]{2}{*}{ 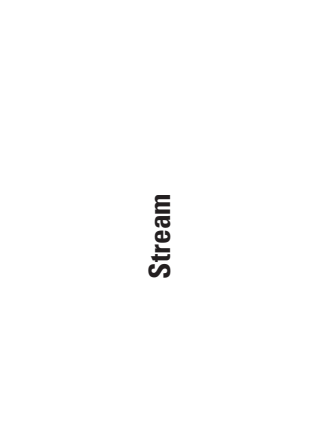 } & \multirow[b]{2}{*}{ 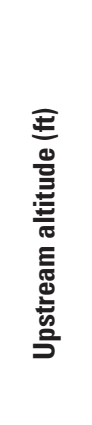 } & \multirow[b]{2}{*}{ 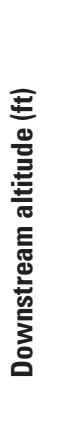 } & \multirow[b]{2}{*}{ 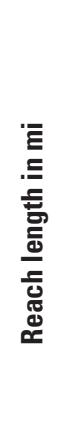 } & \multirow[b]{2}{*}{ 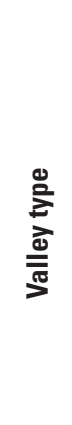 } & \multirow[b]{2}{*}{ 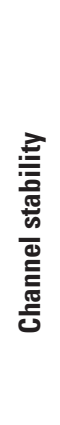 } & \multicolumn{8}{|c|}{ Geomorphic processes } & \multirow[b]{2}{*}{ 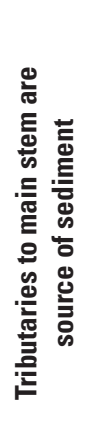 } & \multirow[b]{2}{*}{ 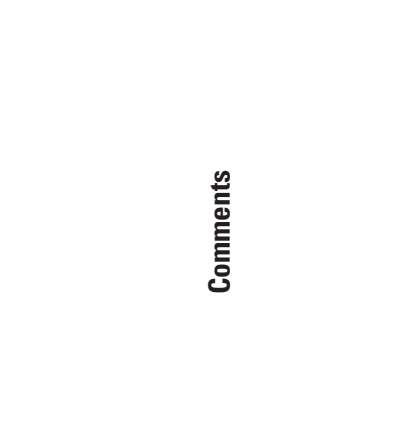 } \\
\hline & & & & & & & 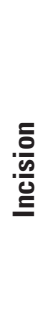 & 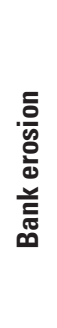 & 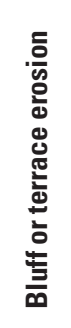 & 믈 & 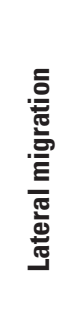 & 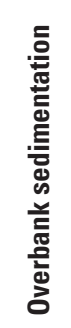 & 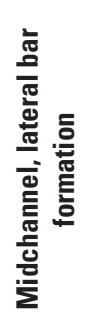 & 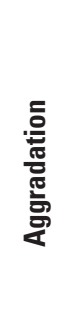 & & \\
\hline \multicolumn{17}{|c|}{ Sioux River-Continued } \\
\hline $\mathrm{L}$ & Sioux River & 630 & 615 & 1.3 & A & U & & $\mathrm{X}$ & $\mathrm{X}$ & $\mathrm{X}$ & $\mathrm{X}$ & $\mathrm{X}$ & $\mathrm{X}$ & & $\mathrm{X}$ & Very unstable, high banks. \\
\hline M & Little Sioux River & 1,090 & 970 & 1.2 & $\mathrm{~A} / \mathrm{C}$ & S? & & & & & & & & & & Provides runoff but no sediment. \\
\hline $\mathrm{N}$ & Little Sioux River & 970 & 870 & 1.2 & $\mathrm{C}$ & U & $\mathrm{X}$ & $\mathrm{X}$ & & $\mathrm{X}$ & & & $X$ & & $?$ & Beaver activity, local aggradation. \\
\hline $\mathrm{O}$ & Little Sioux River & 870 & 795 & 1.4 & $\mathrm{C}$ & U & $\mathrm{X}$ & $\mathrm{X}$ & $\mathrm{X}$ & $\mathrm{X}$ & $\mathrm{X}$ & $\mathrm{X}$ & $\mathrm{X}$ & & $\mathrm{X}$ & Very unstable. \\
\hline $\mathrm{P}$ & Little Sioux River & 795 & 770 & 0.7 & $\mathrm{C} / \mathrm{E}$ & $\mathrm{U}$ & $\mathrm{X}$ & $\mathrm{X}$ & & $\mathrm{X}$ & $\mathrm{X}$ & $\mathrm{X}$ & $\mathrm{X}$ & & $\mathrm{X}$ & \\
\hline Q & Little Sioux River & 770 & 755 & 0.3 & $\mathrm{C}$ & $\mathrm{U}$ & & $X$ & & $\mathrm{X}$ & $\mathrm{X}$ & $\mathrm{X}$ & $\mathrm{X}$ & $\mathrm{X}$ & $\mathrm{X}$ & $\begin{array}{l}\text { Beaver activity and common log } \\
\text { jams, multi-channels, common } \\
\text { sand deposition. }\end{array}$ \\
\hline $\mathrm{R}$ & Little Sioux River & 755 & 720 & 0.6 & $\mathrm{C}$ & $\mathrm{U}$ & $?$ & $\mathrm{X}$ & $\mathrm{X}$ & & & & & & $?$ & \\
\hline $\mathrm{S}$ & Little Sioux River & 720 & 630 & 1.0 & $\mathrm{C}$ & U & & $\mathrm{X}$ & & $\mathrm{X}$ & & & & & $?$ & $\begin{array}{l}\text { Bedrock channel, sand/gravel } \\
\text { deposition in reaches between } \\
\text { bedrock falls and rapids. }\end{array}$ \\
\hline $\mathrm{T}$ & Little Sioux River & 630 & 615 & 0.6 & A & $\mathrm{U}$ & & $\mathrm{X}$ & & $\mathrm{X}$ & $\mathrm{X}$ & $\mathrm{X}$ & $\mathrm{X}$ & & $?$ & \\
\hline $\mathrm{U}$ & Sioux River & 615 & 608 & 0.9 & A & $\mathrm{U}$ & & $\mathrm{X}$ & & $\mathrm{X}$ & $\mathrm{X}$ & $\mathrm{X}$ & $\mathrm{X}$ & & & \\
\hline \multirow[t]{2}{*}{$\mathrm{V}$} & Sioux River & 608 & 602 & 1.1 & A & $\mathrm{U}$ & & & $\mathrm{X}$ & & & $\mathrm{X}$ & & $\mathrm{X}$ & & Bluff cut near mouth. \\
\hline & Sioux River total miles & & & 28.3 & & & & 9.6 & 16.8 & 12.0 & 12.6 & 11.6 & 12.6 & 12.7 & 3.1 & \\
\hline
\end{tabular}


Table 7. Summary of geomorphic characteristics and processes by altitude for five Bayfield Peninsula streams, Wisconsin. Reaches are shown on figs. 13-17.

[ft, feet; mi, mile. Stream: R., River; us, upstream; Cr., Creek; ds, downstream; S., South; Br., Branch. Valley type: U, unconfined; C, confined; A, alluvial; E, entrenched. Channel stability: S, stable; $\mathrm{U}$, unstable. Geomorphic processes: X, geomorphic characteristic or process is present. Comments: LWD, large woody debris.]

\begin{tabular}{|c|c|c|c|c|c|c|c|c|c|c|c|c|c|c|c|c|}
\hline \multirow[b]{2}{*}{ 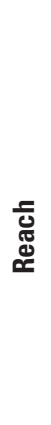 } & \multirow[b]{2}{*}{ 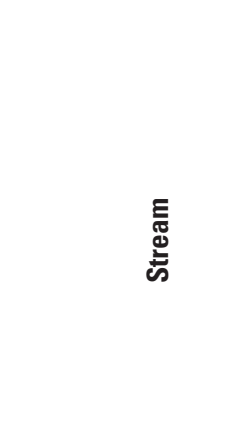 } & \multirow[b]{2}{*}{ 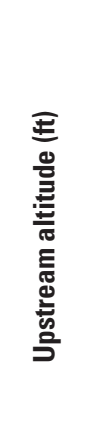 } & \multirow[b]{2}{*}{ 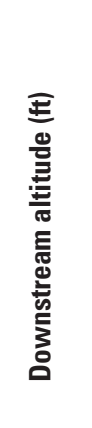 } & \multirow[b]{2}{*}{ 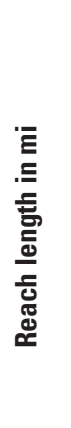 } & \multirow[b]{2}{*}{ 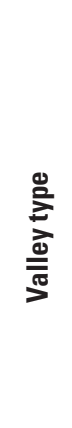 } & \multirow[b]{2}{*}{ 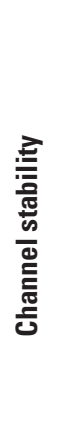 } & \multicolumn{8}{|c|}{ Geomorphic processes } & \multirow[b]{2}{*}{ 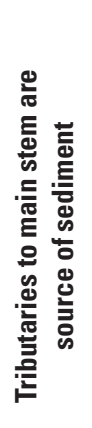 } & \multirow[b]{2}{*}{ 冚 } \\
\hline & & & & & & & 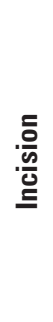 & 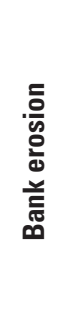 & 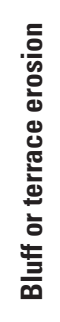 & 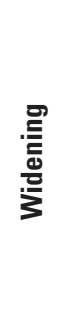 & 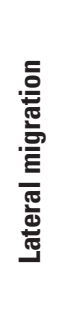 & 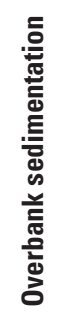 & 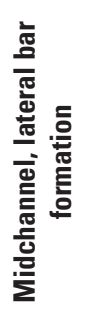 & 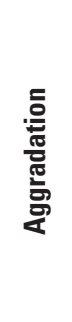 & & \\
\hline \multicolumn{17}{|c|}{ Whittlesey Creek } \\
\hline A & Whittlesey Creek & 1,110 & 1,020 & 0.4 & $\mathrm{~A} / \mathrm{C}$ & $\mathrm{S}$ & & & & & & & & & & $\begin{array}{l}\text { Contributes runoff but little or no } \\
\text { sediment. }\end{array}$ \\
\hline $\mathrm{B}$ & Whittlesey Creek & 1,020 & 970 & 0.2 & $\mathrm{C}$ & $\mathrm{U}$ & $\mathrm{X}$ & & & & & & & & $\mathrm{X}$ & $\begin{array}{l}\text { Ephemeral channel, boulders com- } \\
\text { mon. }\end{array}$ \\
\hline $\mathrm{C}$ & Whittlesey Creek & 970 & 880 & 0.7 & $\mathrm{C}$ & $\mathrm{U}$ & $\mathrm{X}$ & $\mathrm{X}$ & $\mathrm{X}$ & & & & & & $X$ & $\begin{array}{l}\text { Eroding terraces/bluffs common; } \\
\text { substrate is boulders and sand, } \\
\text { cascading where steep, sand } \\
\text { splays where slope flattens, } \\
\text { LWD hanging over channel. }\end{array}$ \\
\hline $\mathrm{D}$ & Whittlesey Creek & 880 & 760 & 1.4 & $\mathrm{C} / \mathrm{E}$ & $\mathrm{U}$ & $\mathrm{X}$ & $X$ & $\mathrm{X}$ & $\mathrm{X}$ & $\mathrm{X}$ & & $X$ & & $\mathrm{X}$ & $\begin{array}{l}\text { Eroding terraces, bluffs common; } \\
\text { widening and gravel bars com- } \\
\text { mon downstream of eroding } \\
\text { bluffs. }\end{array}$ \\
\hline $\mathrm{E}$ & Whittlesey Creek & 760 & 670 & 1.1 & $\mathrm{C} / \mathrm{E}$ & $\mathrm{U}$ & & $X$ & $\mathrm{X}$ & $\mathrm{X}$ & $\mathrm{X}$ & $X$ & $\mathrm{X}$ & & $\mathrm{X}$ & $\begin{array}{l}\text { Eroding terraces/bluffs common; } \\
\text { gravel bars common, chan- } \\
\text { nel may totally fill with sand } \\
\text { between floods. }\end{array}$ \\
\hline $\mathrm{F}$ & Whittlesey Creek & 670 & 640 & 0.6 & $\mathrm{C} / \mathrm{E}$ & $\mathrm{U}$ & & $\mathrm{X}$ & & $X$ & $X$ & $\mathrm{X}$ & $X$ & & & $\begin{array}{l}\text { confluence with the North Fork, } \\
\text { gravel bars common. }\end{array}$ \\
\hline G & Whittlesey Creek & 640 & 620 & 0.8 & A & $\mathrm{U}$ & $\mathrm{X}$ ? & $\mathrm{X}$ & & $\mathrm{X}$ & $\mathrm{X}$ & $\mathrm{X}$ & $\mathrm{X}$ & & & $\begin{array}{l}\text { boulder riffles at about } 625 \mathrm{ft} \text {; wid- } \\
\text { ening and migration where large } \\
\text { trees fall have fallen in. }\end{array}$ \\
\hline $\mathrm{H}$ & Whittlesey Creek & 620 & 610 & 0.4 & A & $\mathrm{U}$ & & $\mathrm{X}$ & & & $\mathrm{X}$ & $\mathrm{X}$ & & $\mathrm{X}$ & & \\
\hline I & Whittlesey Creek & 610 & 602 & 0.4 & A & $\mathrm{U}$ & & & & & $\mathrm{X}$ & $\mathrm{X}$ & & $X$ & & Avulsion, rare LWD. \\
\hline \multicolumn{3}{|c|}{ Whittlesey Creek total miles } & & 6 & & & & 3.1 & 5.0 & 3.2 & 3.9 & 4.7 & 3.3 & 3.9 & 0.8 & \\
\hline
\end{tabular}


entrenched channels because of the accumulation of overbank sediment. Flood-plain attenuation of high flows is limited, except for large floods that are high enough to spill over onto terrace surfaces.

Near the mouth of North Fish Creek at similar altitudes as cores from site 30 on the Cranberry River indicate that $5-7 \mathrm{ft}$ of historical alluvium was deposited after Euro-American settlement (Fitzpatrick, 1998) (fig. 25B-C). Radiocarbon ages from wood samples from core G-7 indicate that historical sedimentation rates for North Fish Creek are four to six times higher than presettlement sedimentation rates. Presettlement sedimentation rates for the mouth area of the Cranberry River were not determined, but the depth of historical sedimentation near the mouth of the Cranberry River appears to be somewhat less than that of North Fish Creek (3-4 ft vs. 5-7 ft).

\section{Bark River}

Similar to the Cranberry River, headwater channels of the Bark River (reach A and reach E) act as conduits for runoff, and road crossings are point sources for sand (fig. 14, table 7). No terrace or bluff erosion was observed from helicopter video footage along the upper main stems (reaches B, C, F, G), but Inter-Fluve, Inc. and Graber (2003) observed terrace and bluff erosion in reach B from about 700 to $650 \mathrm{ft}$ in their field surveys. Sand deposition is present in reaches with beaver dams (reaches D, H, and I). The Bark River from 650 to $630 \mathrm{ft}$ (reach I) also shows evidence of lateral instability, including bank erosion, widening, lateral migration, overbank sedimentation, and bar formation. No evidence for bedrock outcrops was observed, but boulder zones were common in the channel from about 630 to $650 \mathrm{ft}$, with major boulder zones from 660

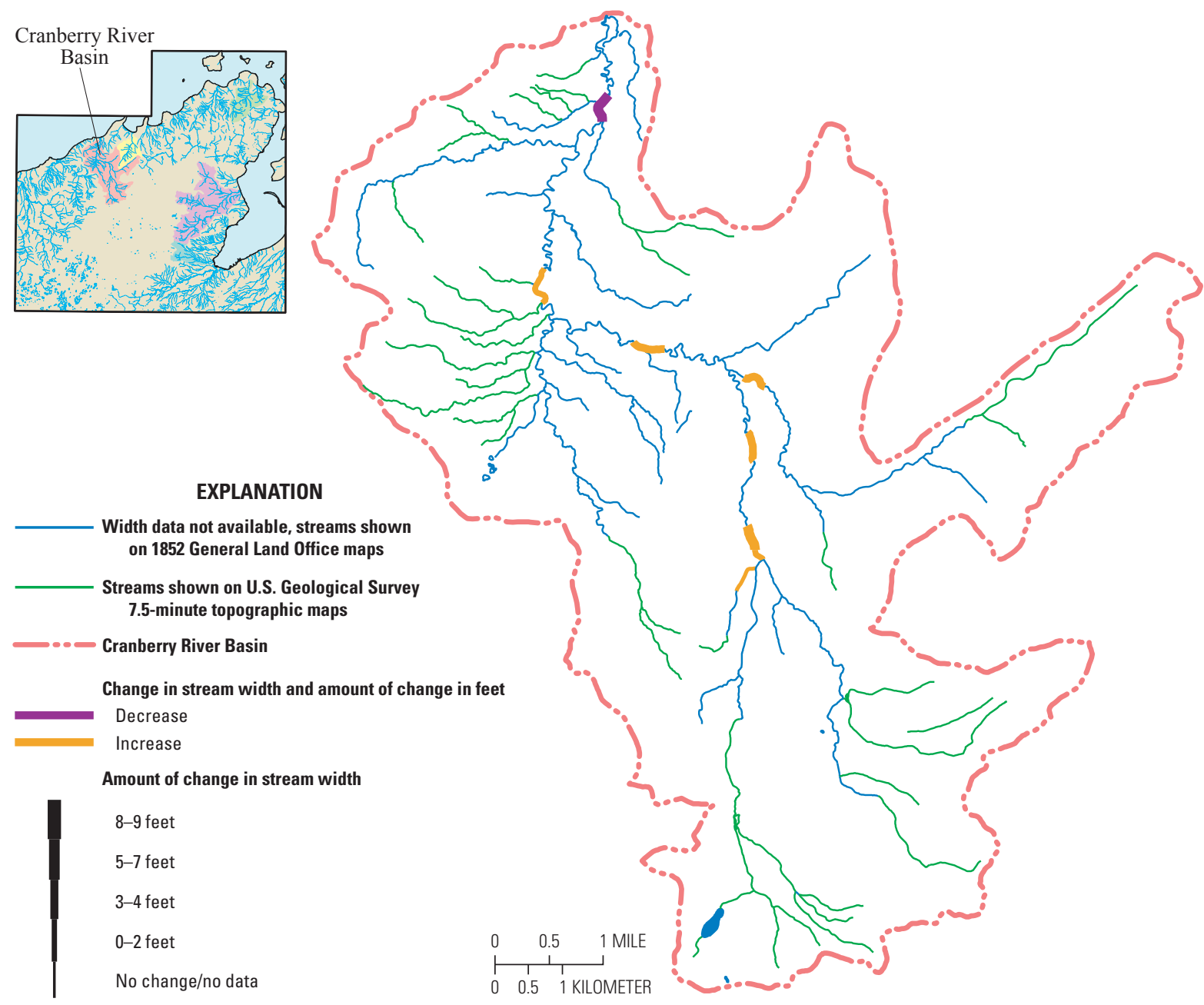

Figure 18. Differences in stream network development and channel widths in the Cranberry River Basin between 1852 General Land Office Survey maps, USGS 7.5-minute topographic maps, and 2002-2003 field surveys. 
to $700 \mathrm{ft}$. Downstream of about $630 \mathrm{ft}$, the Bark River valley changes from entrenched to alluvial. Sedimentation rates near the mouth are not known.

\section{Raspberry River}

Helicopter-based video footage for the Raspberry River was not available and interpretations of channel conditions are based on 2000 aerial photography, base-flow survey photos from 2002, and Inter-Fluve, Inc. and Graber (2003) observations (fig. 15, table 7). The headwaters of the Raspberry River start at 1,190 ft, and the channels may be stable down to about $1,100 \mathrm{ft}$ or less (reach A). The valley is confined from 1,100 to $900 \mathrm{ft}$ as the stream cuts down through the old Duluth shoreline (reach B). From 900 to $820 \mathrm{ft}$, the valley widens and the slope decreases as the stream flows across the level lake-plain areas from postglacial Lakes Moquah and Washburn (reach C); bank erosion is common (Inter-Fluve, Inc. and Graber, 2003). Eroding bluffs were evident on 2000 aerial photographs from an altitude of 820 to $690 \mathrm{ft}$ (reaches D and E). Reach F (690-655 ft) has bank erosion and bar formation and possibly lateral migration and overbank sedimentation. Downstream of $655 \mathrm{ft}$ (reach G), bank erosion, lateral migration, and depositional bar formation are common, and possibly overbank sedimentation. On the basis of conditions in other streams with this same altitude range, terrace and bank erosion and overbank sedimentation are probably common. Downstream of $610 \mathrm{ft}$, the channel most likely is aggradational as the valley widens considerably and the slope decreases (reach $\mathrm{H}$ ).

\section{Sioux River}

Similar to the Cranberry River and Bark River, headwaters of the Sioux River (reaches A, F, and M) provide runoff but little sediment to downstream reaches (fig. 16, table 7). Downstream in reach B ( $950-890 \mathrm{ft}$ ), beaver activity is common (dams and evidence of old dams). Bluff and terrace erosion is common in reaches C, D, and E (890-690 ft). Along this 6.5 -mile reach, at least 26 bends had bluff or terrace erosion in the helicopter video. This reach is very similar to the zone of bluff erosion on North Fish Creek from about 920 to $680 \mathrm{ft}$ (fig. 11). In reach J (690-660 ft), channel conditions are somewhat more stable compared to upstream and downstream reaches. This is similar to the same, more stable reach $\mathrm{J}$ of the Cranberry River for the same altitude range. Bedrock crops out along the Sioux River between 660 and 630 feet (reach K).

Observations of channel conditions from the helicopter video of Fourmile Creek (reaches G, H, and I) are limited because of thick evergreen forest cover in the riparian zone for most of the creek's length. Glimpses of the channel between the trees however suggest that conditions are stable except for some occasional bank and terrace erosion. Fourmile Creek drains the east side of a glacial meltwater valley; the same valley is drained on the west side by the upper main stem of the East Fork of the Cranberry River. The remnants of this glacial meltwater valley can be seen on the 10-m DEM map (fig. 3), the Quaternary geologic map (fig. 4) and the soils map (fig. 7). The two streams are similar in that they both extend into the sand deposits of the Bayfield Highlands more than the other streams. Valleys of the East Fork Cranberry River and Fourmile Creek are over-widened compared to valleys for other streams at the same altitude, possibly because of thick sand deposits and valley development during glacial meltwater events.

The Little Sioux River appears incisional in reaches N, $\mathrm{O}$, and $\mathrm{P}(970-770 \mathrm{ft})$ with some bank erosion. Bluff and terrace erosion was observed in reaches $\mathrm{O}$ and $\mathrm{R}(870-795 \mathrm{ft}$ and 755-720 ft). Bedrock crops out in reach S (720-630 ft), and sand and gravel bars are common in depositional areas between falls and rapids.

Downstream of the confluence of the Little Sioux River (reach U from 615-608 ft), with the Sioux River, bank erosion, widening, lateral migration, and bar formation are common. The Sioux River near its mouth (below $608 \mathrm{ft}$ in reach V) is aggradational.

\section{Whittlesey Creek}

Similar to the other streams, there is little or no erosion in headwaters of Whittlesey Creek (fig. 17, table 7) above an altitude of about 1,020 ft. The headwater channels are sources of runoff for downstream reaches which have incision, terrace and bluff erosion. The Whittlesey Creek watershed has the highest percentages of pasture/grassland and cropland of the five studied streams, with more than double the area of grassland/pasture than the Sioux River basin and more than three times the area of grassland/pasture than the Cranberry River and Bark River basins (fig. 7, table 1). Thus, more runoff from headwaters and erosion along the main stem are possible in Whittlesey Creek than in the other studied streams (table 1).

Similar to North Fish Creek, terrace and bluff erosion are common on Whittlesey Creek from about 970 to $670 \mathrm{ft}$. In the helicopter video, more than 30 meander bends had extensive terrace or bluff erosion in this 3.2-mile reach. The main Whittlesey Creek and the North Fork channels above $670 \mathrm{ft}$ receives little base flow and may be completely filled with sand or gravel between floods. This is especially evident in reach $\mathrm{D}$, which appeared to have been perennial as late as the 1930s but filled with sediment in the 1940s causing the reach to dry up (RCIC, 1957).

Base flow increases substantially in reaches $F$ and $G$ (670-620 ft) because a regional aquifer intersects the stream channel (Lenz and others, 2003) (fig. 6). At about $670 \mathrm{ft}$, a terrace surface along the main stem of Whittlesey Creek had about $3 \mathrm{ft}$ of historical alluvium (medium-grained sand) overlying an organic-rich presettlement soil developed in loamy fine sand. The top of the buried soil was $2.5 \mathrm{ft}$ above the 1999 channel thalweg. Reaches F and G have sand overbank sedimentation, levee formation, and common gravel and sand bars (bars are mainly gravel in reach F and sand in reach G). Bank 


\section{$\boldsymbol{A}$}

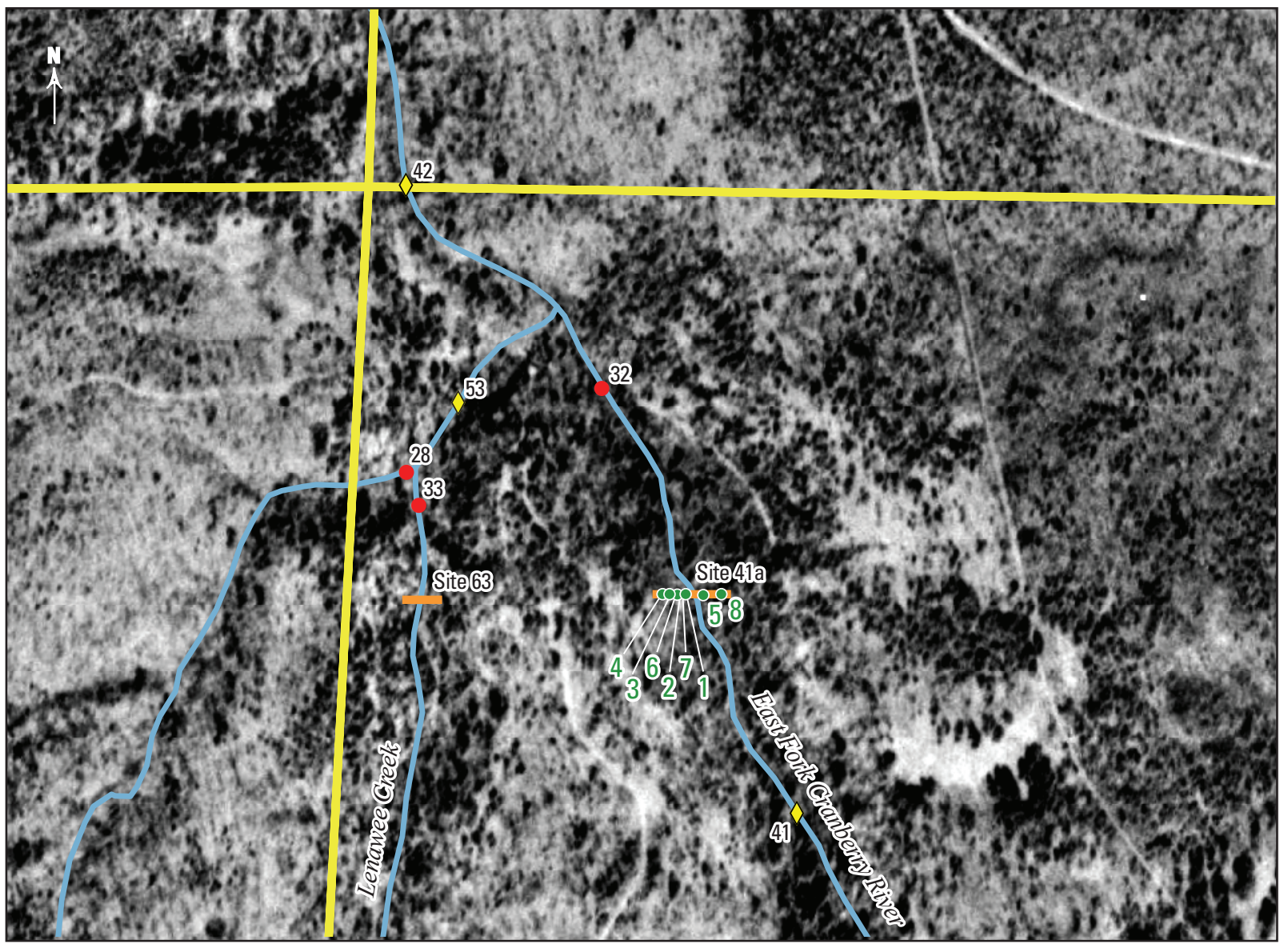

Base from 1992 aerial photography and Wisconsin Department of Natural Resources hydrography: 1:24,000 digital data

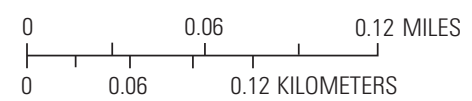

\footnotetext{
EXPLANATION

3 . Core location and number

${ }^{41} \checkmark$ Inter-Fluve, Inc. site and field number (table 2)

33 U.S. Geological Survey (USGS) base-flow survey site and field number (table 2)
}

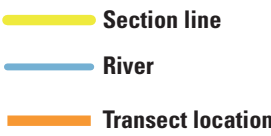

Figure 19. Cross sections and sediment cores at site 41 (East Fork Cranberry River) and site 63 (Lenawee Creek): $A$, site map, and $B$, cross section and core descriptions.

erosion is common and local lateral migration is common at treefalls. In reach $\mathrm{G}$, there was some evidence of channel incision; the channel bottom in an undated abandoned channel near site 67 was $0.5 \mathrm{ft}$ higher in altitude than the active channel bottom. This small difference in channel altitude, however, needs to be field-verified with core data from other abandoned channels. Overbank sedimentation is high in this reach and natural levees are present, especially along the outside of meander bends; the levees give the channel an entrenched look.
Near the mouth of Whittlesey Creek, conditions change from being dominated by bank erosion and lateral migration to aggradation. Site 2 is located in reach $\mathrm{H}$, where overbank sedimentation (levee formation) and channel aggradation are dominant geomorphic processes. Geologic descriptions of sediment cores along a channel cross section at site 2 (figs. 26A-B) illustrate the amount of aggradation in this reach. Willows line the reach and were probably planted in the late 1940s through 1960s (the trees need to be cored and dated to verify their ages). A root crown from a willow along the 


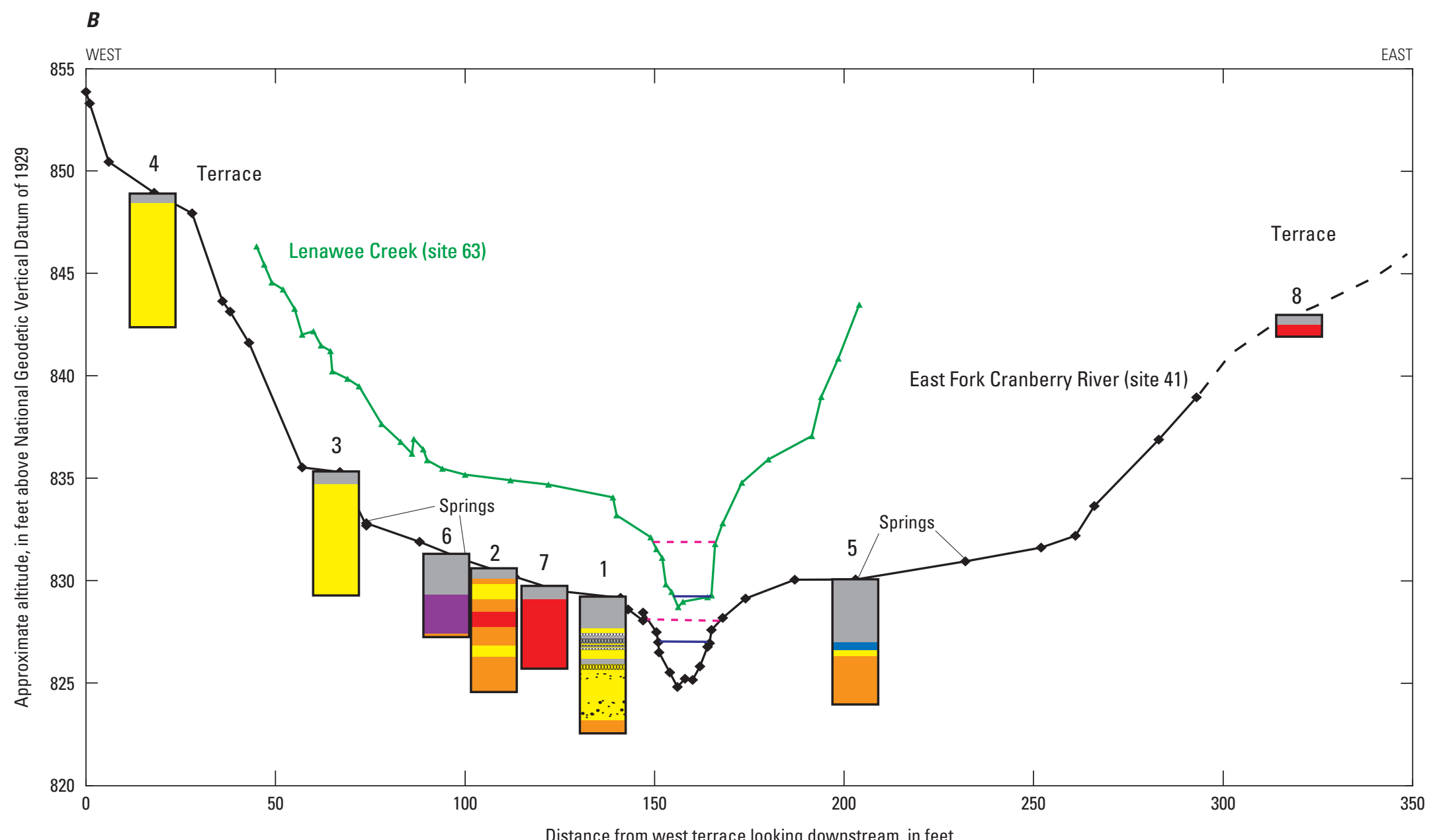

EXPLANATION

\begin{tabular}{|c|c|c|c|c|}
\hline Red clay & Gravel & \multirow{4}{*}{ Core and identification number } & mamanow & Wood \\
\hline Mottled red and gray clay & Organic-rich loam, clay or muck & & TाTाT & Buried soil \\
\hline Gray clay & Silt & & --- & Bankfull elevation \\
\hline Fine sand & Loam & & - & Low-flow water elevation \\
\hline Medium/coarse sand & & & & \\
\hline
\end{tabular}

Figure 19. Cross sections and sediment cores at site 41 (East Fork Cranberry River) and site 63 (Lenawee Creek): $A$, site map, and $B$, cross section and core descriptions.-Continued 


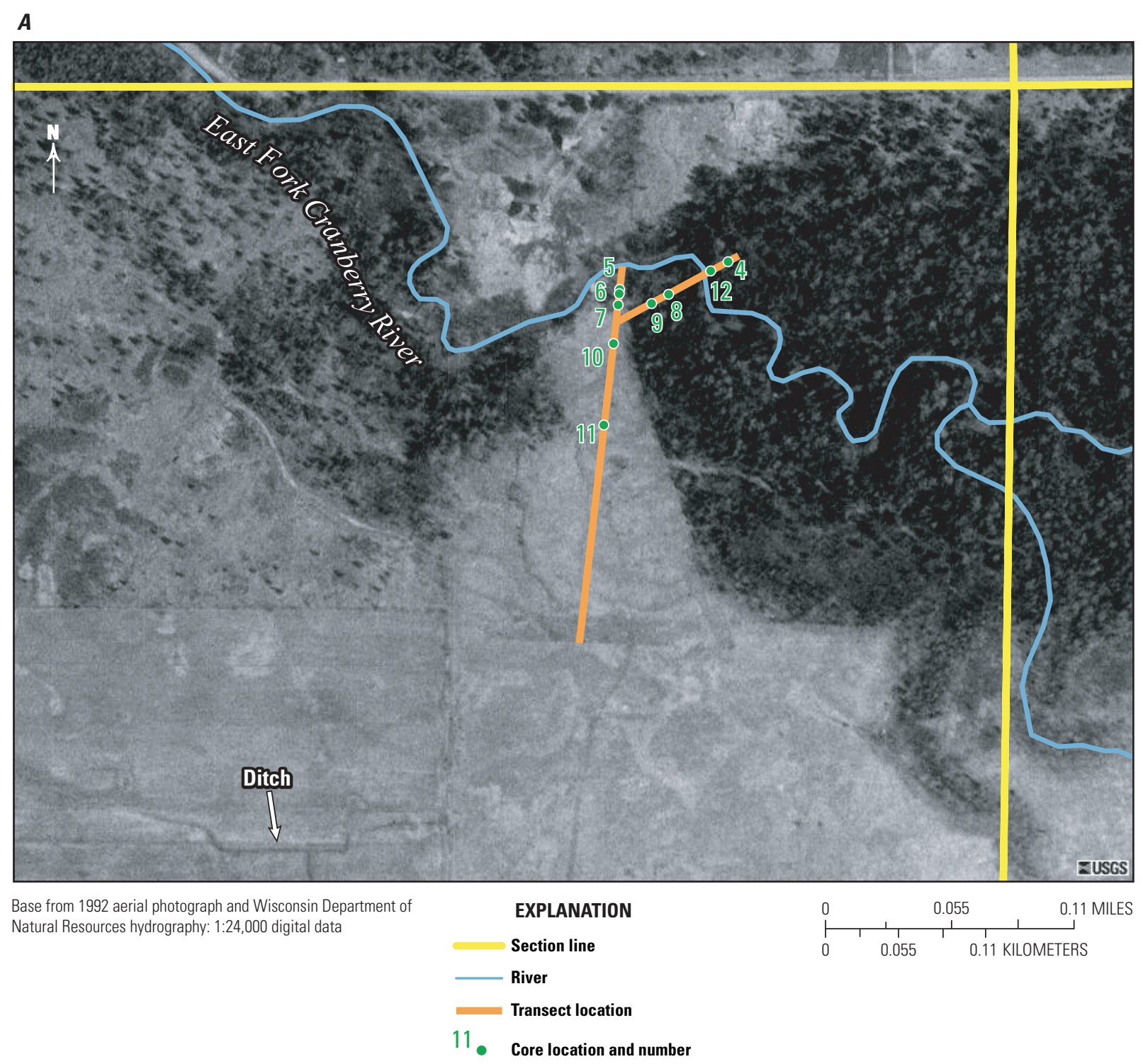

Figure 20. Cross sections and sediment cores at site 46 (East Fork Cranberry River): $A$, site map, $B$, west-east cross section and core descriptions, and $C$, north-south cross section and core descriptions.

cross section at site 2 was buried by $1.6 \mathrm{ft}$ of fine to medium sand deposits with two buried A horizons. There was also a buried A horizon at the same altitude as the root crown. The sand was deposited episodically during large floods. The sand at the surface was probably deposited during the 1999 and 2001 floods (fig. 9).

The 30 -ft core at site 2 (core 2-1) illustrates the aggradational setting of the reach and episodic deposition of sand before and after Euro-American settlement (fig. 26B). Approximately $8 \mathrm{ft}$ of sand and small gravel overlies fine-grained, organic rich silty clay interpreted to be the pre-Euro-American settlement soil. This is somewhat more than the 5-7 ft of historical alluvium deposited along the flood plain of the lower main stem of North Fish Creek (fig. $25 B-C$ ) and twice the amount of historical alluvium on the flood plain of the Cranberry River near its mouth at site 30 (fig. 24B). Because the North Fish Creek watershed has percentages of pasture/grassland and cropland similar to those in the Whittlesey Creek watershed, sedimentation rates would be expected to be similar. Some of the presettlement soil may have been removed during the 1946 flood from scour. About $4.5 \mathrm{ft}$ of coarse sand and gravel (from about 613.5 to $617 \mathrm{ft}$ in core 2-1) above the pre-Euro-American settlement surface was probably deposited during the 1946 flood. Anecdotal evidence from a previous 


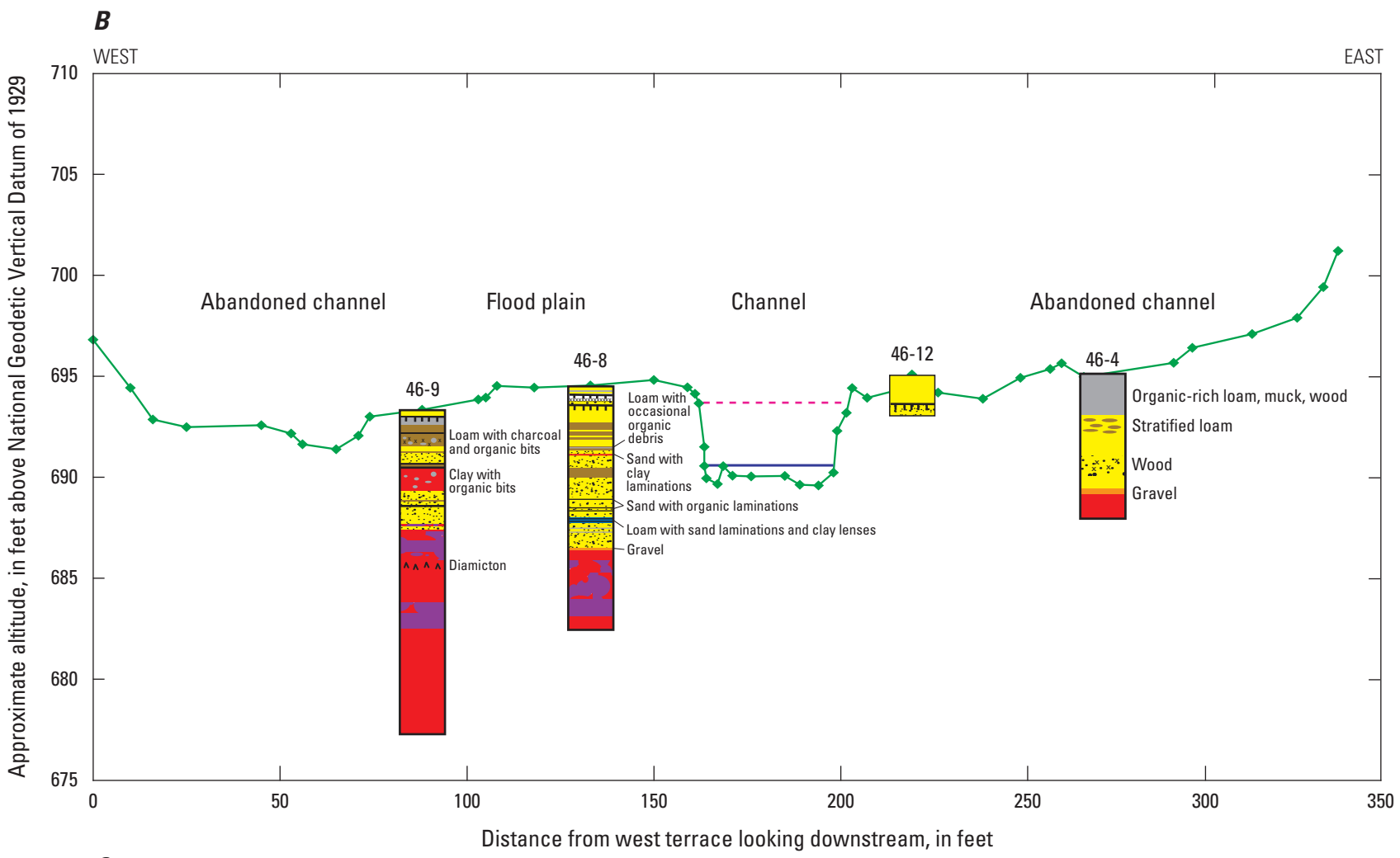

C

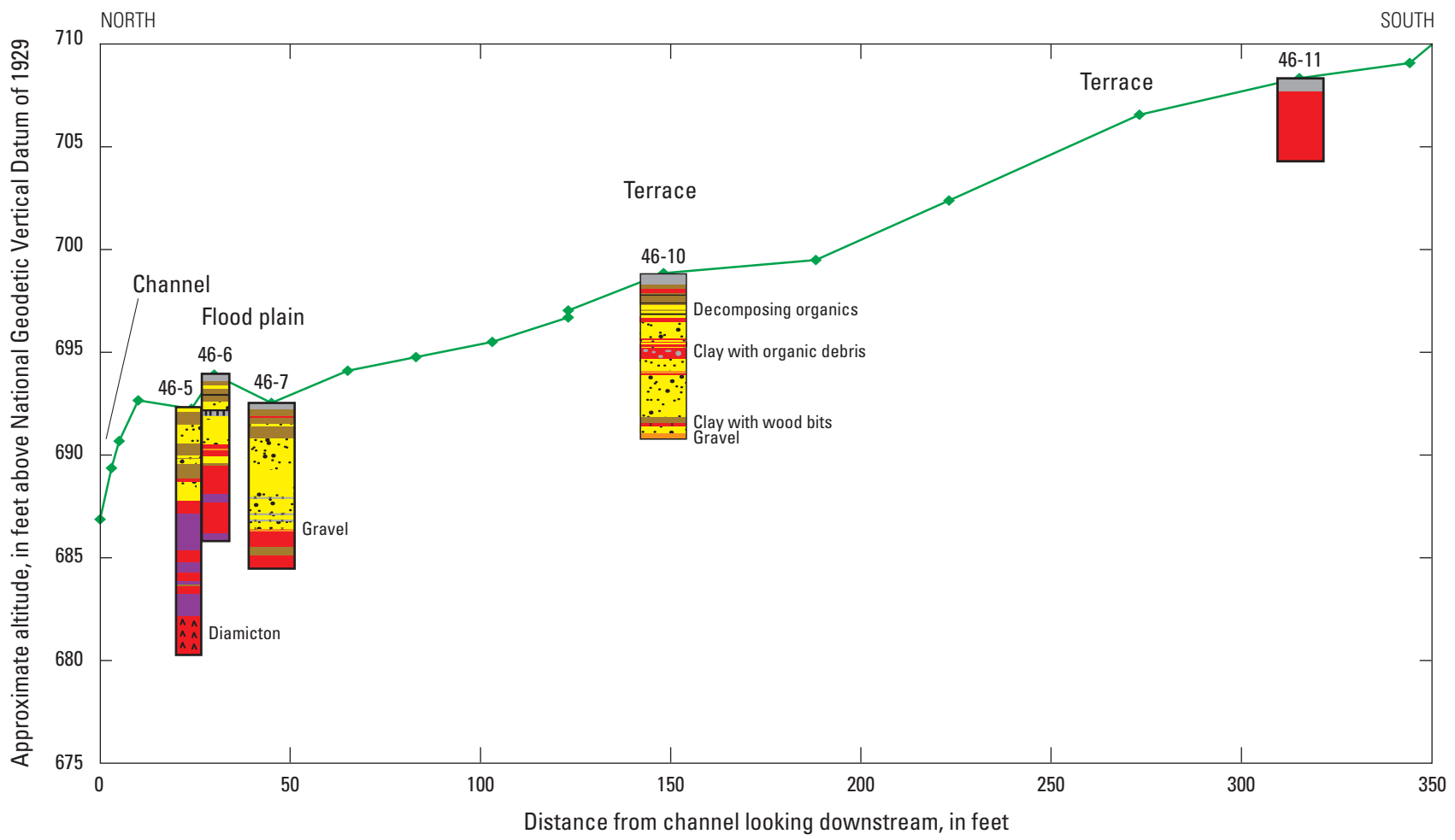

EXPLANATION
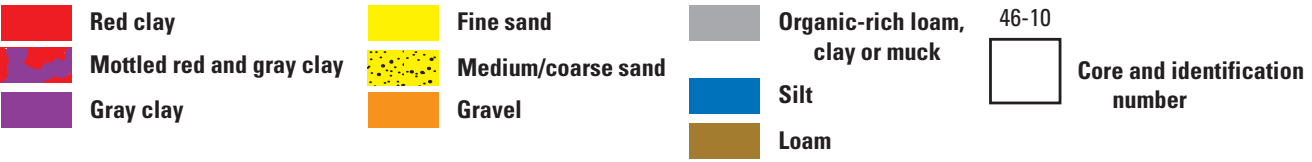

sooxoxoxax Wood

TIIT Buried soil

- - - Bankfull elevation

Low-flow water elevation

Figure 20. Cross sections and sediment cores at site 46 (East Fork Cranberry River): $A$, site map, $B$, west-east cross section and core descriptions, and $C$, north-south cross section and core descriptions.-Continued 

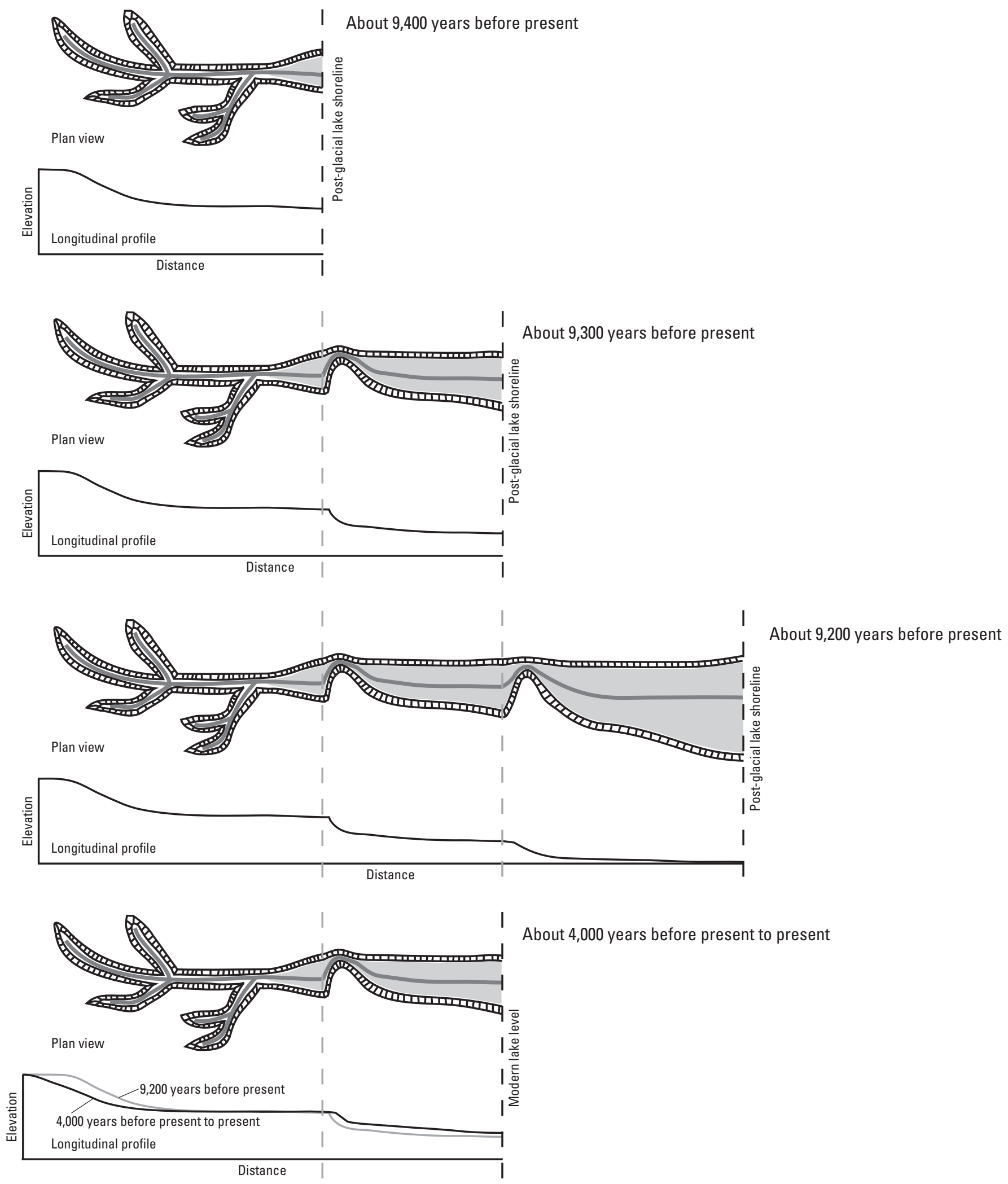

Figure 21. Longitudinal profile and valley development for Bayfield Peninsula streams in response to episodic lowering of postglacial lake levels. 
landowner at site 2 indicates that an old trolley car on the bank at the farmstead at this location slipped into Whittlesey Creek during the 1946 flood and was covered with sediment from subsequent floods (Silver and Lichtenheld, 2003).

Episodes of sand deposition alternate with fine-grained, organic- and wood-rich loam and clay below the presettlement surface in Whittlesey Creek core 2-1 (fig. 26B). This is similar to deposits in cores G-1 and G-7 along the flood plain near the mouth of North Fish Creek (figs. 17A, 25B-C). No radiocarbon-age dating was done on wood samples from core 2-1 along Whittlesey Creek; however, based on radiocarbon ages of wood in Fish Creek cores G-1 and G-7, the 30-ft Whittlesey core probably extends back to about $4,000{ }^{14} \mathrm{C} \mathrm{yr}$ BP (fig. $25 B-C$ ). The valley bottom is likely at an altitude of about $560 \mathrm{ft}$, based on the presence of red-clay diamicton and clay/silt deposits at about this altitude in the North Fish Creek cores (fig. 25B).

The channel along reach I was dredged to a due east course between Hwy 13 and the mouth in September of 1949 by the U.S. Army Corp of Engineers (RCIC, 1957; 1964; 1977). The channel filled with sediment after a few years, causing upstream flooding and a tendency to reoccupy its previous location. In 1958, the Bayfield County Conservation Department channelized the reach which the channel currently occupied in 2003.

\section{Bankfull-Channel Shear Stress}

Estimates of bankfull-channel shear stress for the studied streams give an idea of the general size of material that potentially can be moved during bankfull conditions. Plots of bankfull-channel shear stress and median sediment size (calculated at Inter-Fluve, Inc. sites by Inter-Fluve, Inc. and Graber, 2003, fig. 1) are shown in figure 27. Site numbers on the plots are on the location map (fig. 1). These bankfull shear-stress calculations are approximate and represent rough averages for the channel. Shear stress can be defined is a function of slope and hydraulic radius (equation1) (Leopold and others, 1964). Most of the data are from the Cranberry River.

The bankfull-channel shear stress data were compared to a curve of critical shear stress as a function of sediment size for quartz sediment in water (Shields, 1936) and a relation for critical shear stress determined by the Highway Research Board (1970) for riprap (fig. 27). The Shields and the Highway Research Board curves represent empirically derived thresholds for particle motion. The Shields curve is based on experiments in flumes for noncohesive sediment and has some known limitations for natural channels; however, the curve commonly is used for channel design and predicting scour (Vanoni, 1975; Chang, 1992; Rosgen, 1996; Fischenich, 2001).

Comparison of bankfull channel shear stress and sediment size with the Shields curve indicates that bottom sediment has the potential to move during bankfull flow at almost all the sites with median sediment sizes of less than $40-50 \mathrm{~mm}$ (fig. 27). However, this comparison cannot be used to predict incision. Some of the Bayfield sites that have the potential for sediment movement during bankfull flow are not incisional because the sites are on middle or lower main stems with abundant supplies of sediment from upstream.

The dependence of shear stress on stream size is apparent when comparing East Fork Cranberry River site 43 with Bark River site 58 and Sioux River site 7 (fig. 27). All sites have channel slopes of about 1 percent. The East Fork Cranberry River site has a shear stress of $1.23 \mathrm{lb} / \mathrm{ft}^{2}$ and the Sioux River site has a shear stress of $1.04 \mathrm{lb} / \mathrm{ft}^{2}$, whereas the Bark River site has a shear stress of $0.62 \mathrm{lb} / \mathrm{ft}^{2}$. The East Fork Cranberry River, Sioux River, and the Bark River sites have basin areas of $9.4 \mathrm{mi}^{2}, 13.6 \mathrm{mi}^{2}$, and $2.0 \mathrm{mi}^{2}$, respectively. The Sioux River and East Fork Cranberry River sites had a mix of sand and gravel substrate and the channels were historically incised but currently vertically stable, lateral erosion was common (including eroding bluffs near the Sioux River site), and overbank deposition and natural levees were common (Inter-Fluve, Inc. and Graber, 2003). The Bark River site also had indications of historical incision but is currently vertically stable, and the substrate consists of gravel and cobble with some sand deposition in pools (Inter-Fluve, Inc. and Graber, 2003).

Brook-trout fingerlings are at sites with and without the potential sediment motion during bankfull flows (fig. 27). Sites with particle sizes greater than $40-50 \mathrm{~mm}$ have less potential for particle motion; some of these sites had brook-trout fingerlings, but others did not. This suggests that brook trout are in streams with bankfull shear stresses of up to about $1.0 \mathrm{lbs} / \mathrm{ft}^{2}$, and most of the Bayfield middle and lower main stems have bankfull shear stresses below this value. It may be that bankfull shear stress is not the limiting factor for brook trout; but instead, they may be limited by shear stresses larger than $1.0 \mathrm{lb} / \mathrm{ft}^{3}$ associated with large infrequent floods, the proximity of groundwater upwellings, or the transport or deposition of fine sediment.

\section{Sources of Sediment}

A summary of rough estimates for the relative contributions of sediment from seven sources to Bayfield Peninsula streams is shown in table 8. Bluff and terrace erosion are major contributors of sediment to the Sioux River, Whittlesey Creek, and North Fish Creek. Multiple sources of sediment in the Cranberry River and Bark River are more evenly distributed.

In all the Bayfield streams an upland source for sediment through surface sheet erosion, rill development, or head cutting is negligible because the uplands are mainly forested (fig. 8). Forested uplands provide more runoff than they did before Euro-American settlement, however, because of a reduction in interception (forests are younger), roughness (less ground cover and organic material), and infiltration (organic horizon on the forest floor is thinner). Presently, LWD is absent in most channels, which was a source of 
$\boldsymbol{A}$

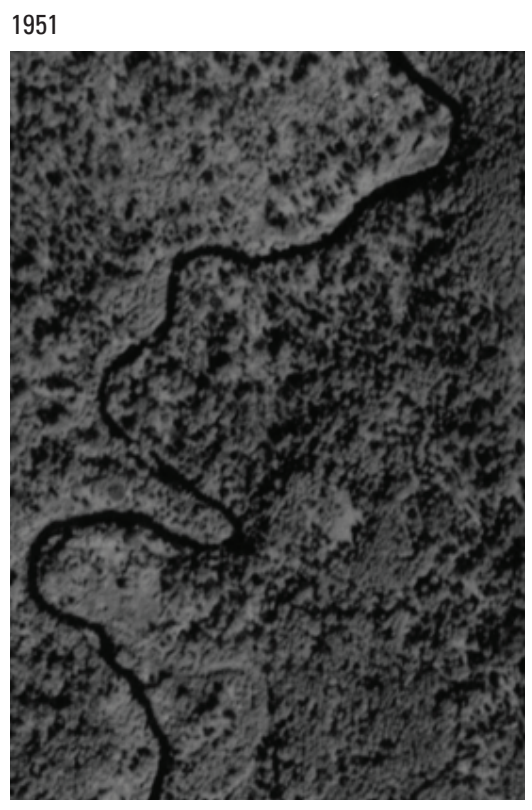

1966
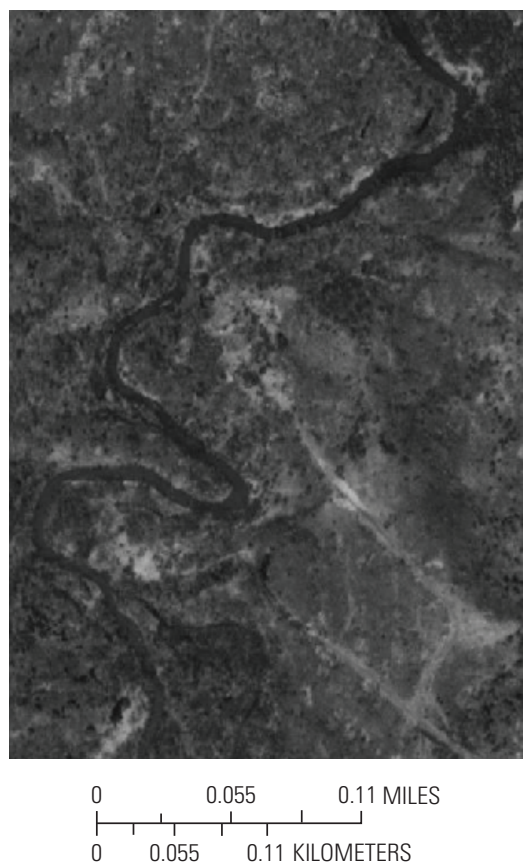

1992

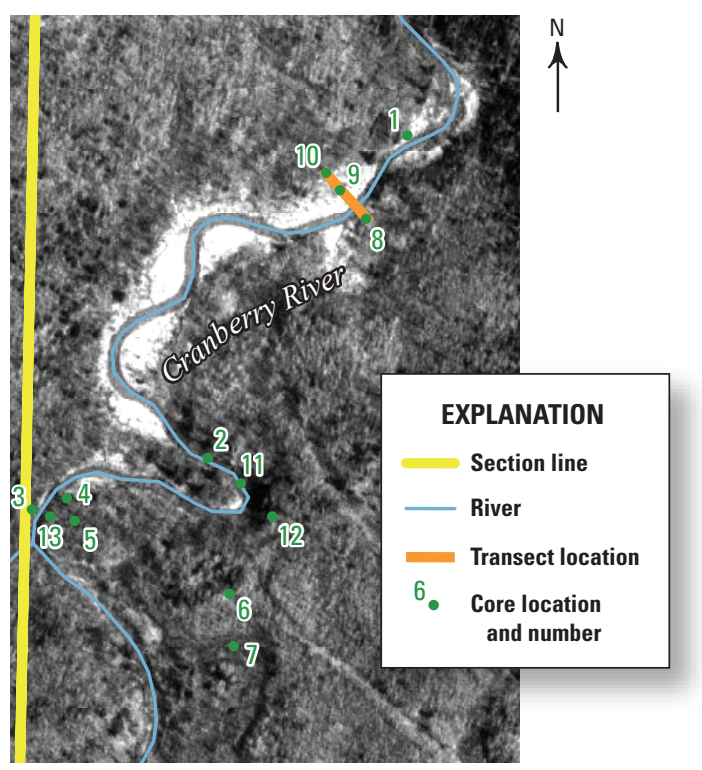

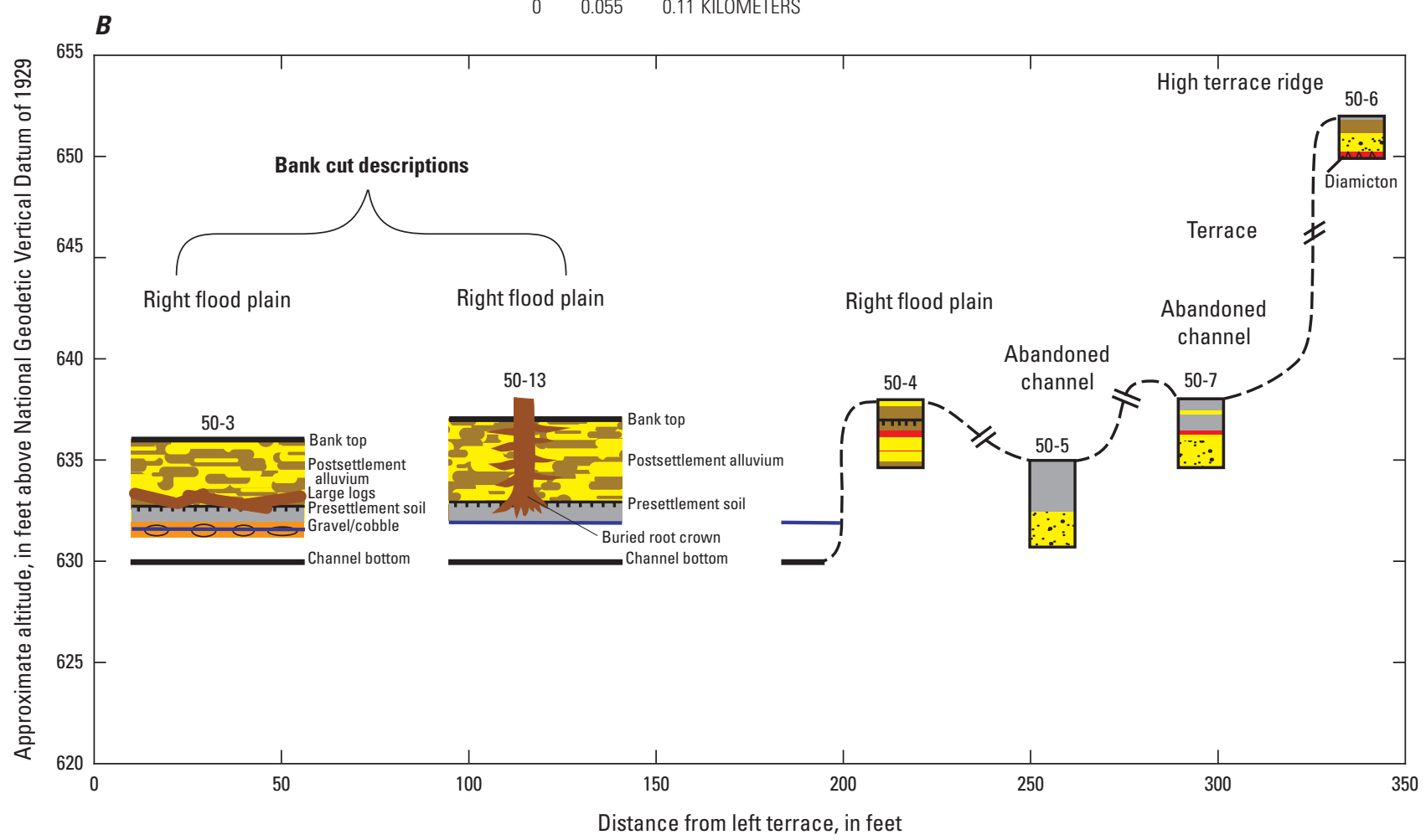

EXPLANATION

Red clay

Mottled red and gray clay

Gray clay

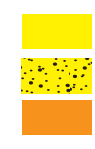

Fine sand

Medium/coarse sand Gravel

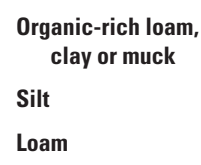

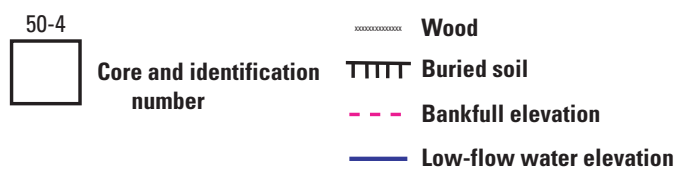

Figure 22. Cross sections, bank and terrace cut geologic descriptions, and sediment cores at site 50 (Cranberry River): $A$, site map comparing aerial photographs from 1951, 1966, and 1992, $B$, bank-cut and core descriptions, $C$, cross section and core descriptions, and $D$, terrace-cut descriptions. 

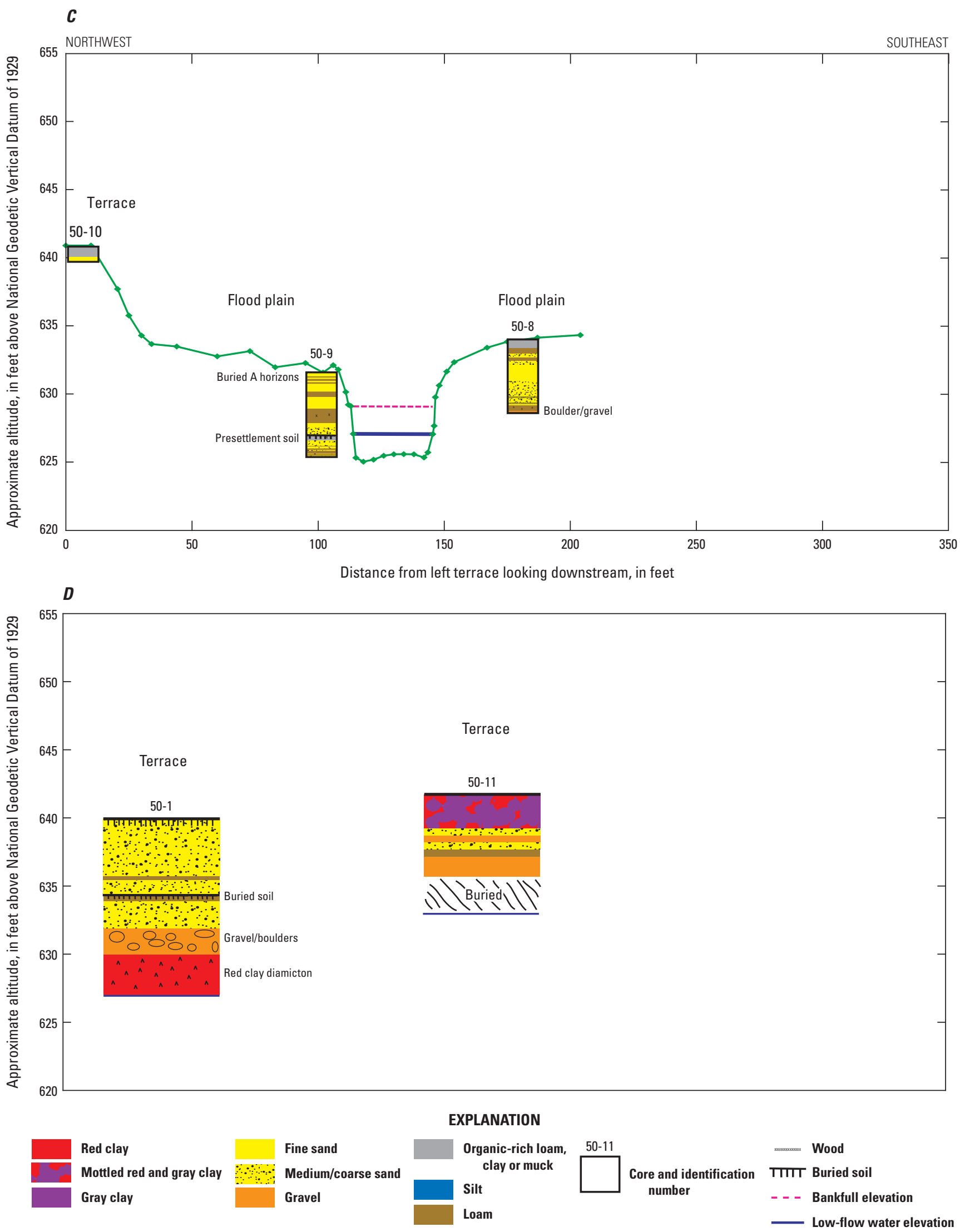

Figure 22. Cross sections, bank and terrace cut geologic descriptions, and sediment cores at site 50 (Cranberry River): $A$, site map comparing aerial photographs from 1951, 1966, and 1992, $B$, bank-cut and core descriptions, $C$, cross section and core descriptions, and $D$, terrace-cut descriptions.-Continued 


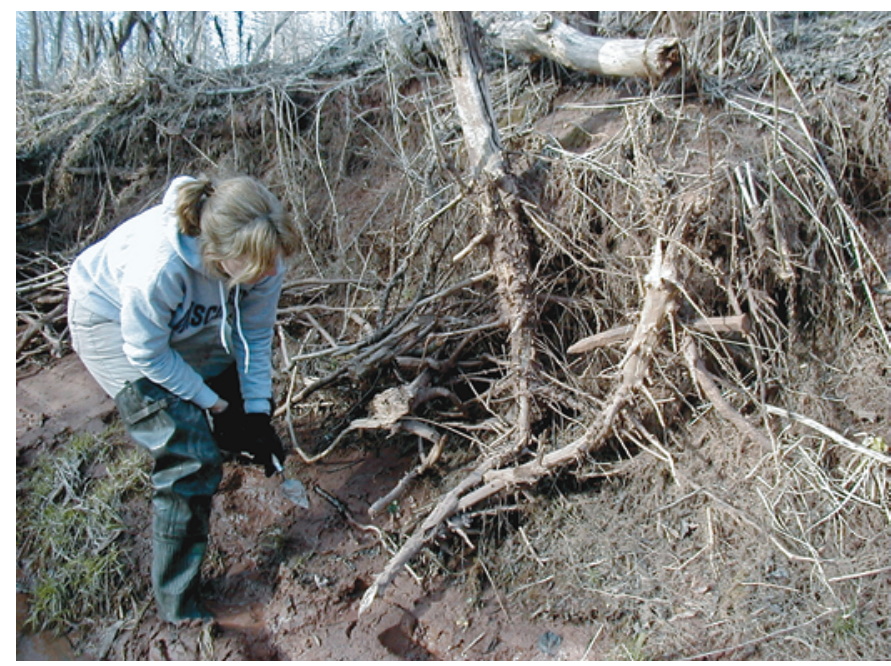

Figure 23. Buried root crown at site 50 along the Cranberry River, Wisconsin.

roughness in presettlement channels, including main stems and feeder tributaries.

As flow is concentrated in the narrower channels of upper main stems, signs of incision are present, indicating that erosion of the upper main-stem channels is a source for sediment. As the streams flow through the steep slopes associated with postglacial shorelines, valleys are confined and conditions are optimal for bluff and terrace erosion in meander bends that intersect valley or terrace sides. Bluff and terrace erosion in Whittlesey Creek and the Sioux River was similar to that observed in North Fish Creek (range in reach altitude from about 890 to $660 \mathrm{ft}$ in the Sioux River and 880 to $670 \mathrm{ft}$ in Whittlesey Creek, and was the main source of sediment to downstream reaches of these rivers. Large bluff cuts are uncommon in the Cranberry River and only small bluff or terrace erosion was common through a smaller altitude drop from about 780 to $640 \mathrm{ft}$. The Bark River had some small bluff and terrace erosion from about 820 to $665 \mathrm{ft}$. Less bluff erosion in the Cranberry and Bark Rivers is probably because of less runoff because of a combination of more forest cover, wider valley development (especially the East Fork of the Cranberry), smaller watershed size, or shorter stream length.

Unimproved logging roads and road crossings provide local sources of sediment. Sediment inputs from crossings of unimproved roads were especially noticeable in the upper parts of the Cranberry and Bark River watersheds. Inter-Fluve, Inc. and Graber (2003) also observed this in the upper parts of the Sioux River.

Erosion of bluffs at meander bends is episodic and thus hard to measure on a year-to-year basis, especially watercaused toe erosion at the base of the bluffs. In the Sioux River and Whittlesey Creek, however, exposed terraces and bluffs are common (about 30 actively eroding bluffs or terraces were observed in the helicopter video footage). Landslides and failures of large bluff sections are episodic but can be longterm sources of sediment. A typical small block failure with a size of about $30 \mathrm{ft} \times 50 \mathrm{ft} \times 5 \mathrm{ft}$ can contribute 300 tons of sediment (if the density of a mixture of sand, silt, and clay is assumed to be $80 \mathrm{lbs} / \mathrm{ft}^{3}$ [U.S. Department of Agriculture, Soil Conservation Service, 1983)]. A typical size of a landslide for larger streams like the Sioux River and North Fish Creek may be $100 \mathrm{ft}$ long by $150 \mathrm{ft}$ high by $15 \mathrm{ft}$ thick (9,000 tons). Most of the sediment from the landslides is moved downstream within a few years after the failure. In some cases, such as the 1975 valley side failure along the lower Cranberry River, the addition of a large amount of sediment overwhelmed the small channel and caused a slowing of flow and increased overbank sedimentation upstream. Downstream effects from a single landslide may last for years or decades as the sand load is transported episodically in waves during large floods. It is not known exactly how long it takes for downstream reaches to adjust to this episodic dump of sand and gravel. In addition, the nonvegetated vertical bluff faces are prone to rill and gully erosion. The prevalence of gravel bars and channel widening downstream of every eroding bluff and terrace is evidence of their large contribution of sediment.

Another important source of sediment during runoff events is small ephemeral feeder channels that bisect the entrenched valley sides. Observations of several of the feeder channels on the Cranberry River, Sioux River, and North Fish Creek during the 2003 snowmelt event indicated that the channels were incised beginning about one-third to two-thirds of the way down the valley's side slopes. Flow from melting snow became turbid in the channels at this point, and erosion was concentrated on the channel bed. The exact point along the valley side slope at which the channels were eroding appeared to depend on the size of the watershed (amount of runoff), aspect of the channel and valley side, amount of nonforested land cover on the upland, and possibly the texture of glacial deposits in the valley sides. For example, south-facing slopes with grassland on the upland produced more runoff and sediment than north-facing slopes with forested uplands. During the 2003 snowmelt, these channels provided clay, silt, and sand to the main stems as well as locally distributing sand from overland flow across flood plains and terrace surfaces. Many of the feeder channels have hanging junctions with upper and middle main stems, and develop knickpoints as they bisect flood-plain and terrace surfaces. Where observed, these features suggest historical incision of the main stem (InterFluve, Inc. and Graber, 2003).

Overbank deposition of sand and natural levee formation are common features downstream of the reaches with bluff and terrace erosion and downstream of reaches with narrow valleys and bedrock controls. The accumulation of sediment in overbank areas tends to give the channels an entrenched look; without adequate flood-plain-stratigraphy data, it would appear that incision is the dominant geomorphic process. The accumulation of overbank sediment leads to a loss of floodplain storage for smaller floods (concentrating flood flows) and causes subsequent increases in the probability of bank erosion, 
block failure, and avulsion. Thus, even though the channel may not be incising, it functions like an incised or entrenched stream by concentrating flood flows to downstream reaches.

The five studied Bayfield streams have shorter depositional or aggradational reaches near their mouths than North Fish Creek (fig. 11). Main stems with more stream length and lower slopes near their mouths have more potential for some sediment from upstream sources to be deposited in overbank areas and within the channel before being carried out to Lake Superior. This is especially the case for Whittlesey Creek, which has the steepest profile (fig. 11), the steepest overall slope (table 6), and a relatively short aggradational zone near its mouth (fig. 17, table 7).

Last, every Bayfield stream has sand deposits that have accumulated in flood plains and channels during the last 125 years. If eroding bluffs and terraces were stabilized, road crossings were improved, and incision and gullying were abated, there is still ample and available sand stored in flood plain and channel deposits. It may take decades or centuries for the sand to move through the entire river system.

\section{Evaluation of Previous Erosion-Control Techniques}

Bluff erosion historically was recognized as a widespread problem for Lake Superior streams and was thought to be a major source of sediment to Lake Superior (Red Clay Interagency Committee, 1967). Thus, five of the six evaluated sites had stabilizations installed to reduce bluff erosion (sites 64, $66,68,69$; fig. 1). One site was a grassed waterway entering North Fish Creek (site 65) and another site evaluated on Whittlesey Creek was geared toward bank erosion (site 67).

At the Bois Brule River site (site 64), gabions (wire baskets filled with rock) and willow plantings were installed on a large south-facing bluff in 1964 by the RCIC. The bluff toe was stable and well vegetated in 1964 (Red Clay Interagency Committee, 1967); however, in 1976, the gabions were failing and there were no live willows, although other woody vegetation had invaded (Red Clay Interagency Committee, 1977). In 2003, no evidence of gabions or any rock material was found near the toe of the bluff. There was a stable toe along 40 percent of the length of the bluff base; the development of this toe could be caused by the original placement of the gabions, which lasted long enough for the woody vegetation to get established. The remainder of the toe had exposed roots and uprooted alders. Old willow logs with young sapling sprouts were along the bluff base. The top of the bluff had mass wasting; and vegetation was sparse because of seeps and earth flows. Although the gabions eventually failed and most of the willow planting died, they may have helped to maintain the toe long enough for vegetation to become established.

One of the larger RCIC projects was stabilizing an eroding bluff on Whittlesey Creek (site 66, fig. 28B). In 1958, the top of the bluff was graded, and runoff from the upland fields was diverted away from the bluff (Red Clay Interagency
Committee, 1964, 1977). The toe was stabilized with cement bagging and willow stakes. By 1960, the cement bagging had washed out, but the willows remained (Red Clay Interagency Committee, 1964). The landowner made additional improvements to the top of the bluff in 1967 (Red Clay Interagency Committee, 1977). At the time of the 1976 RCIC evaluation, the bluff was 90 percent vegetated with good cover and minor tree invasion (Red Clay Interagency Committee, 1977). In 2003, the bluff had a stable base with a few second-growth willows and no bare soil on the bluff face. A few slumps were present from seeps. Overall, the project goals were accomplished at this site, because both the base and the top of the bluff were stabilized.

The bluff on North Fish Creek upstream of the streamflow-gaging station (site 68, fig. 1) was recognized as a problem by the RCIC. The 1977 design plans to reroute the channel away from the bluff were not funded; however, a nearby landowner remembered an attempt by a previous landowner to reroute the channel by use of dynamite (in the 1930s?). The anecdotal evidence from the present landowner indicated that the dynamited channel failed and the bluff became unstable after the attempt. In 2003, the length of the exposed face of the bluff was $470 \mathrm{ft}$. On the upstream end, the bluff had a vertical face with no vegetation and no toe at the base for $150 \mathrm{ft}$. The middle $170 \mathrm{ft}$ of the bluff had some vegetation (about 50 percent), slumping at the top, gullies and seeps through the midsection, and a toe at the base. The downstream end of the bluff had a vertical face with no vegetation and no toe at the base for $150 \mathrm{ft}$. A survey of eroding bluffs along North Fish Creek in 2003 and 2004 (unpublished field notes) indicated that this bluff was in worse condition than many of the other eroding bluffs identified in the mid-1990s (Fitzpatrick, 1998).

Farther upstream on North Fish Creek at another eroding bluff site (site 69), 27 dead willow posts were counted along the base of the bluff in 2003. No design plans were available for this site and the date of installation is not known. The top 20 percent of the bluff had a vertical face; the rest was partially vegetated with slumping, gullying, and mudslides common. Along the base of the bluff was a toe along its entire length with the willow posts half buried from mudslides. Large boulders were present (originating from glacial deposits in the top of the bluff) along the base of the bluff. Even though the willows did not survive, their temporary presence, in combination with a natural buildup of boulders, may have helped stabilize the base of the bluff and allow the building out of a toe.

The 1995 demonstration project to control erosion and stabilize banks on Whittlesey Creek was fulfilling its design goals as of 2003 (site 67, fig. 1). All of the rock barbs were in place and the middle weir had only slight damage. The barbs had stopped bank erosion on the outside of the meander bend and the weirs had kept the main part of the flow toward the center of the channel and had created mid-channel pools. The planted vegetation showed signs of heavy deer browsing. Upstream and downstream of the demonstration project were substantial bank erosion and sand and gravel bar formation. 


\section{$\boldsymbol{A}$}

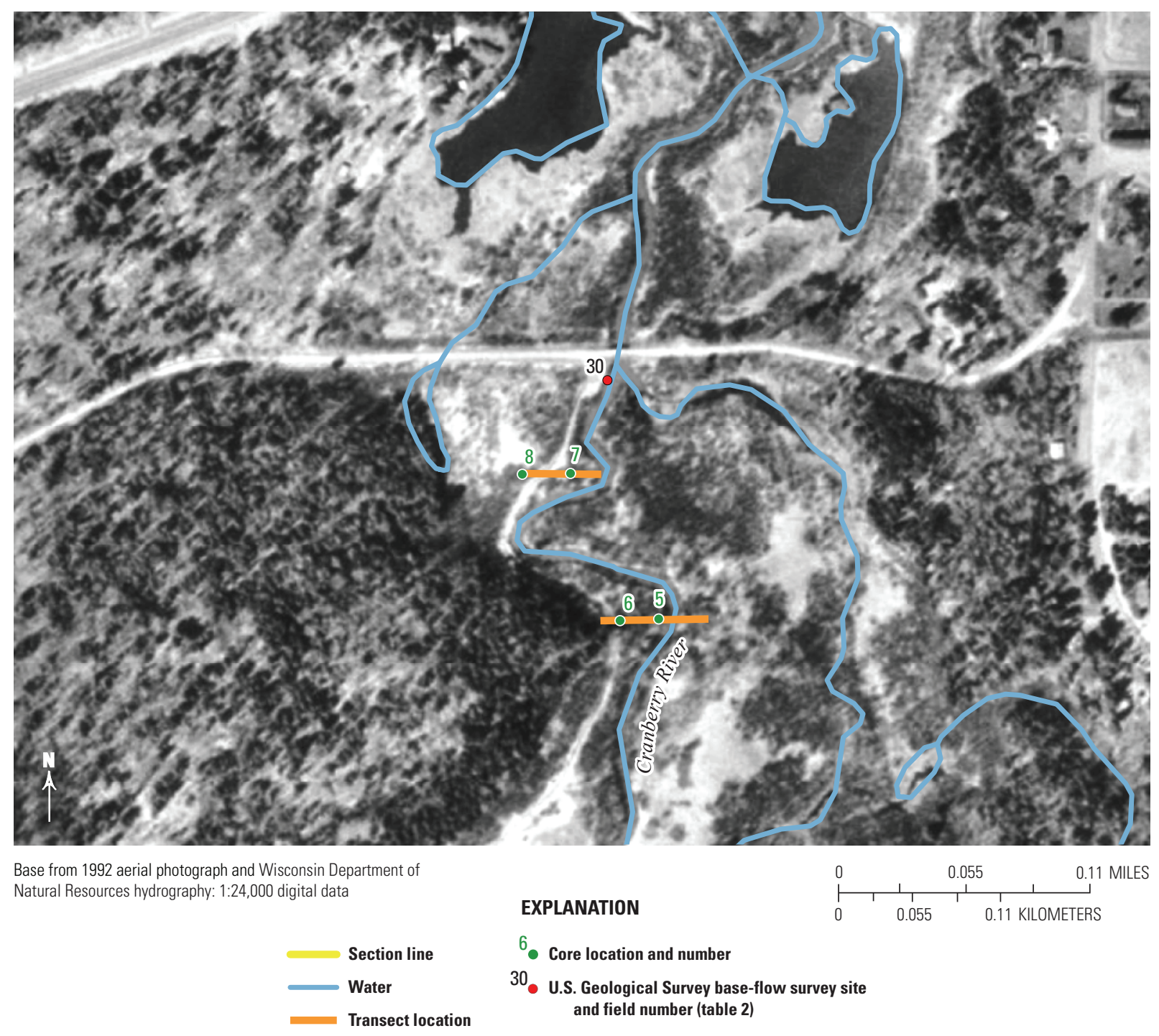

Figure 24. Cross sections and sediment cores at site 30 along the Cranberry River: $A$, site map, and $B$, cross sections and core descriptions.

Grassed waterways and ditches were widely tested by the RCIC. At site 65 along South Fish Creek (fig. 1), the landowner and the RCIC shaped, seeded, and mulched a field waterway in 1961 (fig. 28A). An evaluation in 1962-63 indicated that grazing needed to be prevented and by 1976 the waterway was deemed to be in "excellent condition" (Red Clay Interagency Committee, 1977). In 2003, the waterway was completely vegetated and is contributing no sediment to South Fish Creek.

The RCIC met its goals of reducing erosion at two bluff sites evaluated in this study even though there was little or no evidence of the original structures in 2003. The RCIC conclusions in 1977 were that (1) most of the practices that were implemented lasted for one or two decades, (2) for bluff erosion, the toe is the most important area to stabilize, and (3) for slope stabilization, soil preparation and specific seeding mixes are necessary to establish protective vegetation (Andrews and others, 1979). According to the limited evaluation done in 2003, the RCIC met its goals of reducing erosion and stabilizing slopes at the Whittlesey Creek site. The Bois Brule River bluff (site 64) showed a limited amount of erosion in 2003 (loss of toe and midbluff slumping). The partial success of bluff-erosion control at site 69 indicates that stabilizing a bluff toe will reduce some erosion, but block failures and mudflows from the top of the bluff if not reduced, may destroy toe stabilization efforts. Channel rerouting to reduce bluff erosion, 


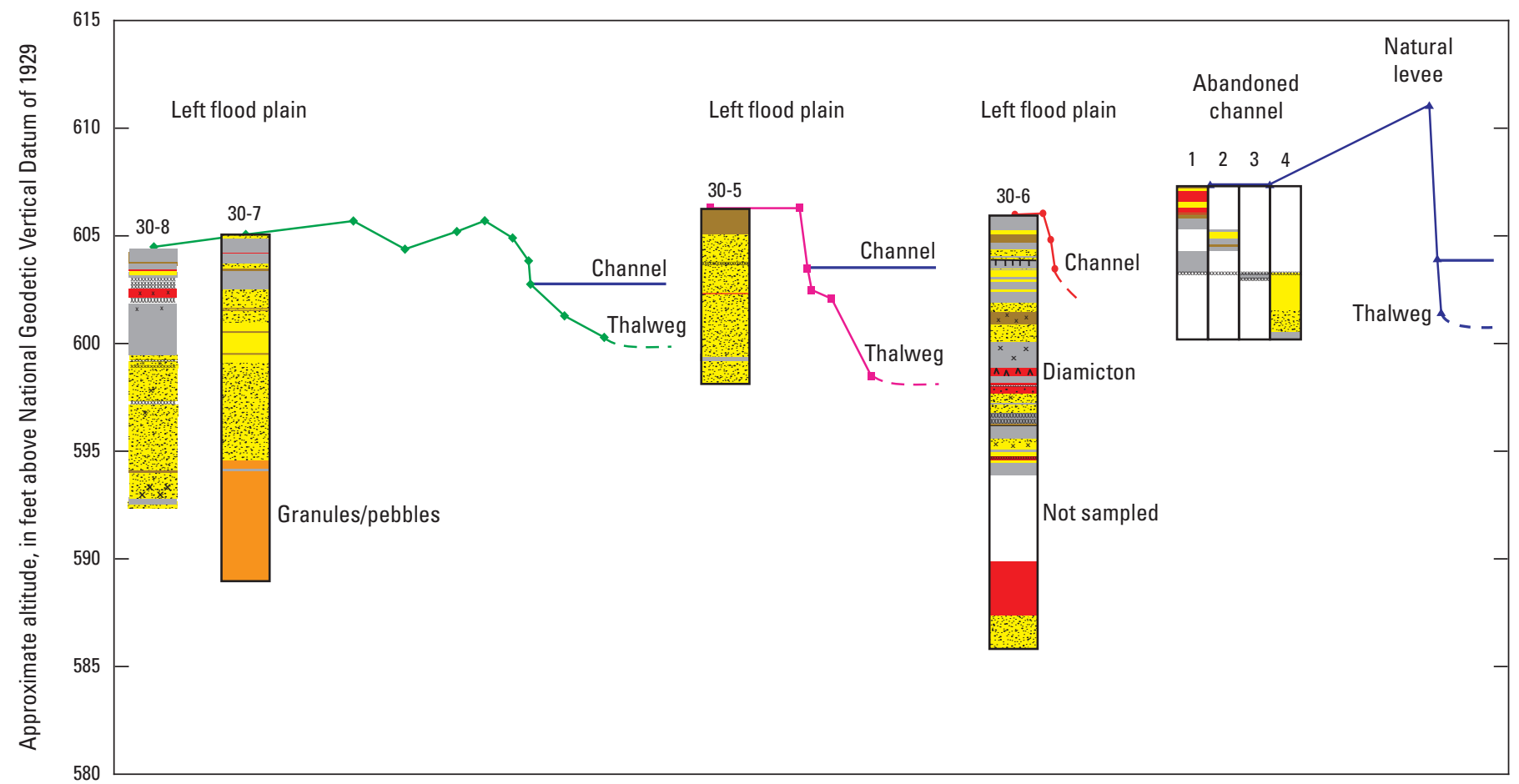

Horizontal distance not to scale

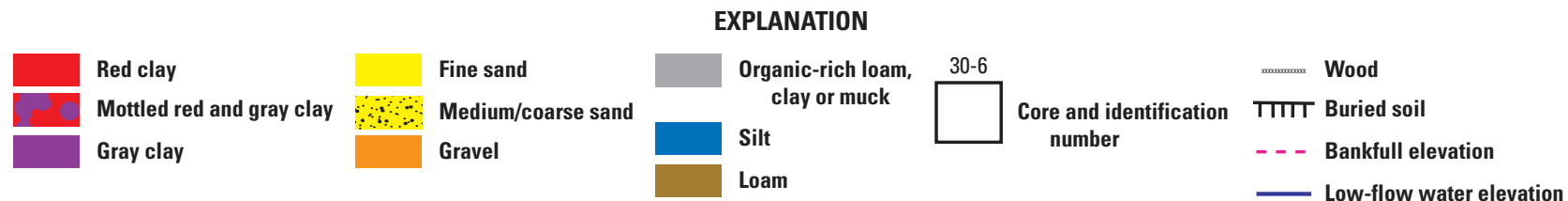

Figure 24. Cross sections and sediment cores at site 30 along the Cranberry River: $A$, site map, and $B$, cross sections and core descriptions.-Continued

such as that attempted at site 68 , is more problematic because channel relocations usually result in a shorter stream length and subsequent increase in slope that may cause local scour and head cutting.

Activities to control erosion and installation of new sites or evaluation and maintenance of older sites tend to follow floods. For example, erosion-control activities began on the Bayfield Peninsula after frequent moderate floods in the mid1950s (fig. 9). The number of site evaluations rose after the 1960 flood. This study took place after the 2001 flood. This may be caused by the possibility that floods increase erosion and raise awareness of erosion issues. The floods may instigate erosion-control projects and promote funding of erosioncontrol measures.

\section{Flood Characteristics}

The combination of historical geomorphic data, floodhydrograph modeling, and sediment-transport data is useful for understanding the complex responses of runoff, sediment movement, and geomorphic processes to historical changes in forest cover. Flood-hydrograph simulations were done with HEC-1 for the Cranberry River Basin (near site 30 at the mouth, fig. 1) for four land-cover scenarios: present (1992-93), presettlement (before 1870), peak agriculture (1928), and developed (possible future scenario). Floodhydrograph simulations for the Cranberry River were compared to flood-hydrograph simulations for North Fish Creek 


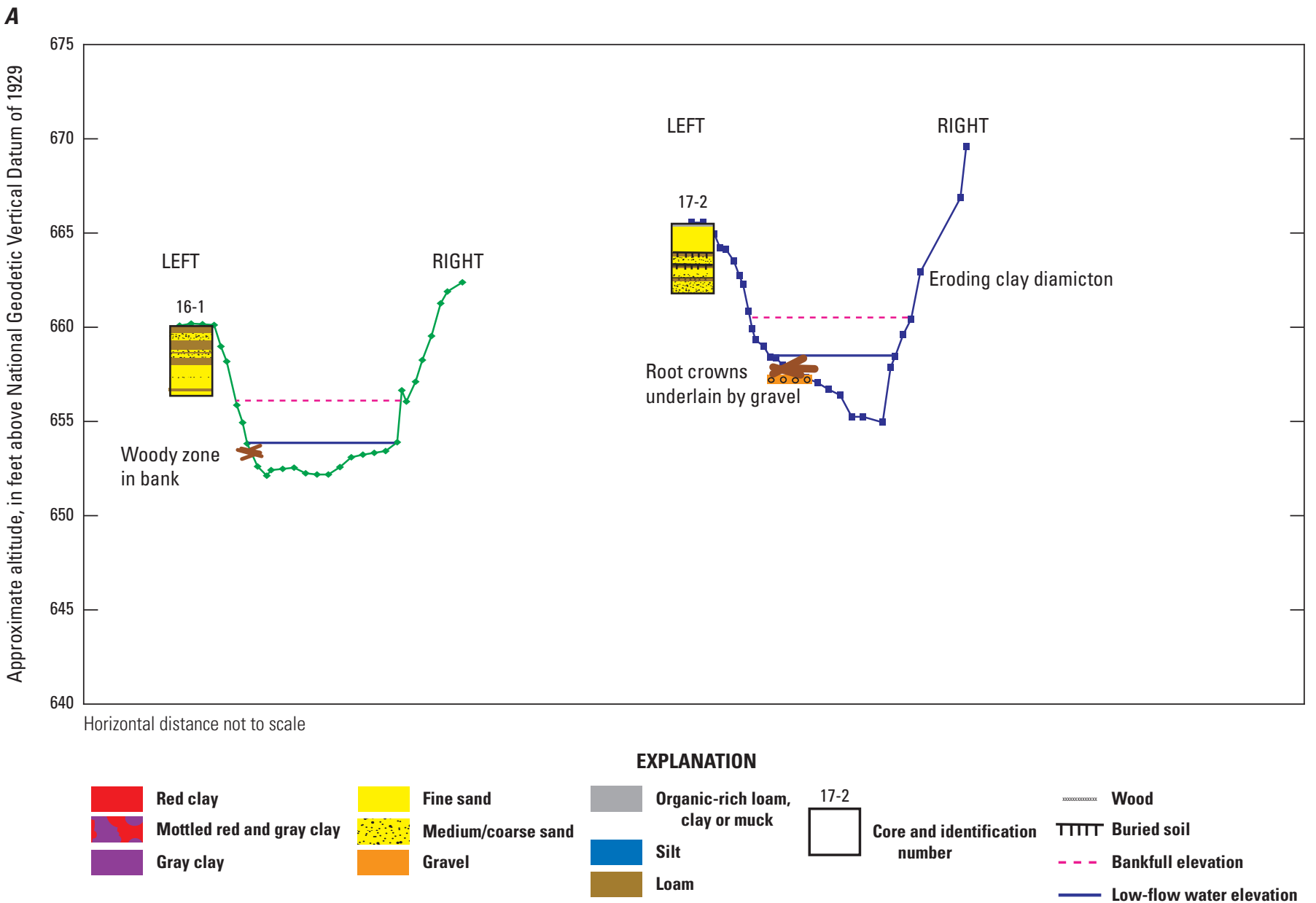

Figure 25. Cross sections and sediment cores from North Fish Creek, Wisconsin (Fitzpatrick, 1998): $A$, cross section and core descriptions for cores 16-1 and 17-2, $B$, cross section and core description for core G-1, and $C$, core description for core G-7. Core locations shown on figure $17 A$.

(site 1, fig. 1) (Fitzpatrick, 1998; Fitzpatrick and others, 1999) and Whittlesey Creek (site 2, fig. 1) (Lenz and others, 2003) for similar land-cover scenarios. Because the Cranberry River does not have a streamflow-gaging station, thus simulated design hydrographs for the Cranberry River are more uncertain than the North Fish Creek and Whittlesey Creek hydrographs, which were based on rainfall records and calibrated and verified against streamflow.

Simulated flood peaks and volumes for the Cranberry River were smallest for the presettlement scenario and greatest for the developed (25 percent urban) scenario (table 9, fig. 29). Presettlement flood peaks were 57 to 46 percent less than 1992-93 flood peaks, but runoff amounts were lower than the 1992-93 runoff amounts by only 5 percent or less. In the presettlement scenario, overland and channel-roughness coefficients were increased to represent a thicker organic debris layer on the forest floor and more LWD in the stream channel.
These changes slowed the rate of runoff (lowered the peak and increased the duration), but did not decrease the total volume of runoff, because the potential for infiltration was similar to infiltration with the 1992-93 land cover. The impacts of increased channel roughness and overland roughness are more important in steep fast-flowing streams like the Cranberry River, because stream energy is proportional to the square of the roughness coefficient (for example, a 2-fold increase in roughness results in a 4-fold loss of kinetic energy).

Flood peaks for peak agriculture (1928) for the Cranberry River were similar to flood peaks for 1992-93 (fig. 29, table 9). Unlike the Sioux River and Whittlesey Creek basins, the percentage of agriculture in 1928 the Cranberry River basin was only slightly higher than in 1992-93 (table 1). The amount of agriculture in the Cranberry River basin in 1928 was also less than in the basins on the east side of the peninsula. In 1928 the Cranberry River basin had 4.4 percent 


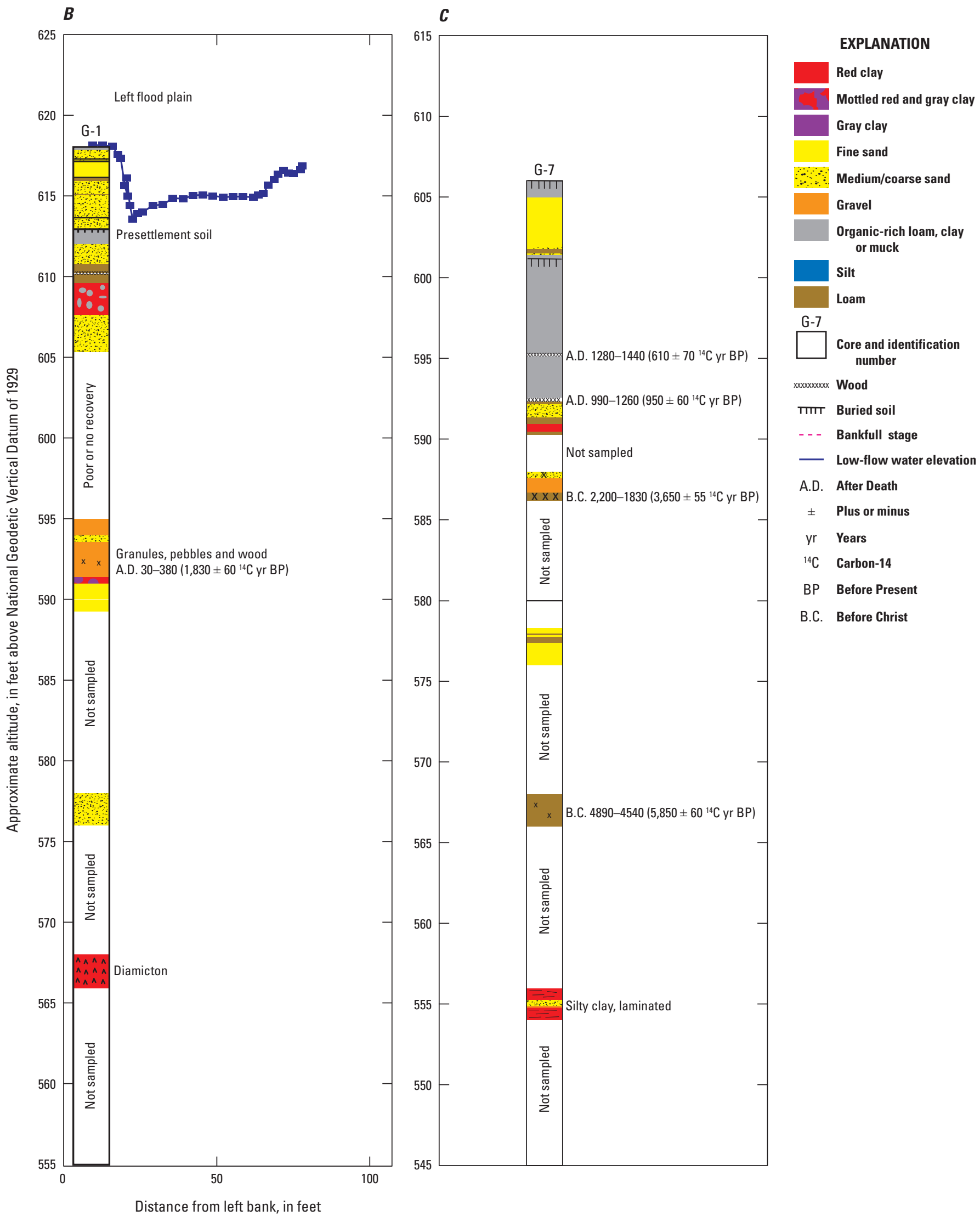

Figure 25. Cross sections and sediment cores from North Fish Creek, Wisconsin (Fitzpatrick, 1998): $A$, cross section and core descriptions for cores 16-1 and 17-2, $B$, cross section and core description for core $\mathrm{G}-1$, and $C$, core description for core $\mathrm{G}-7$. Core locations shown on figure $17 A$. - Continued 


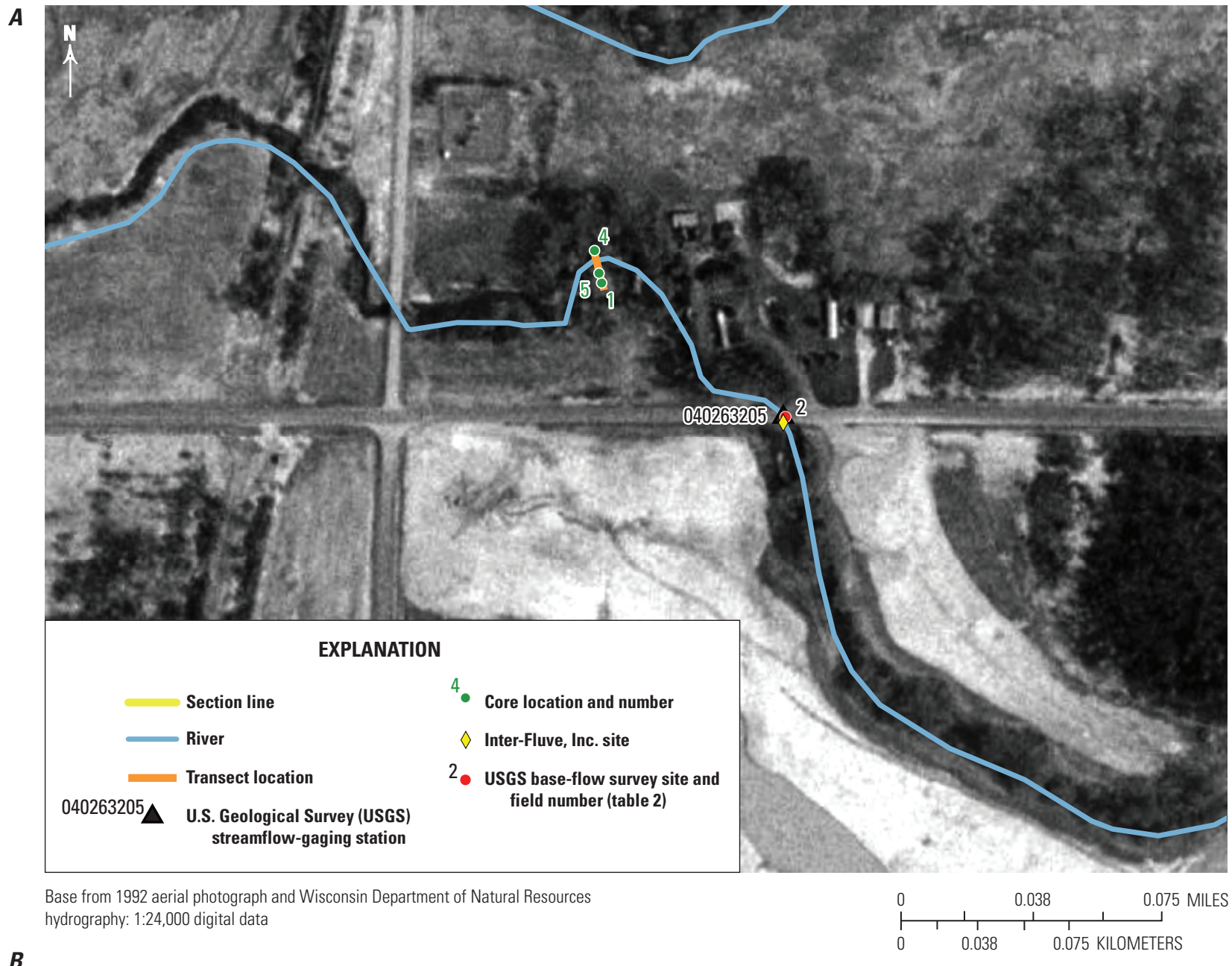

B

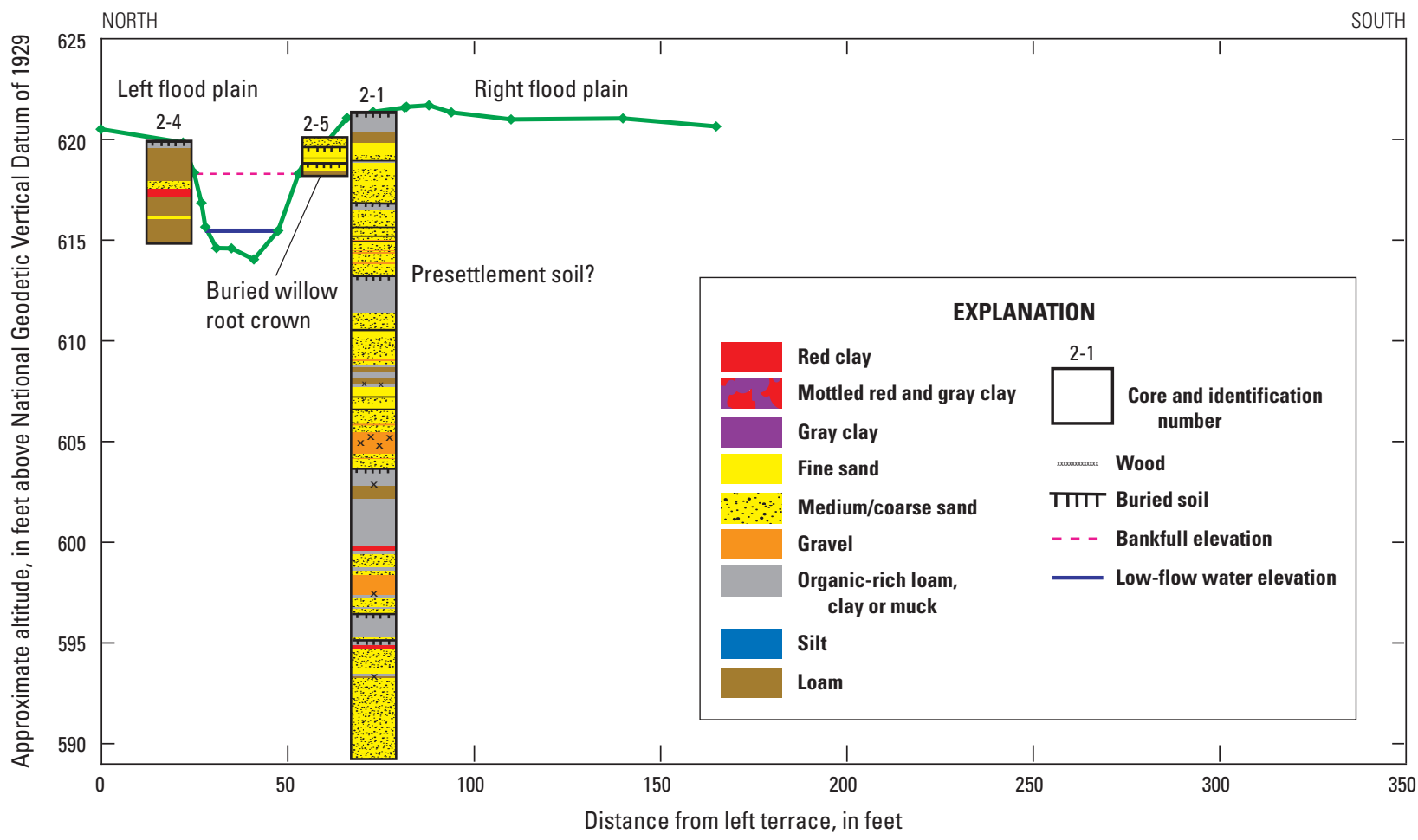

Figure 26. Cross section and sediment cores at site 2 along Whittlesey Creek: $A$, site map, $B$, cross section and core descriptions. 


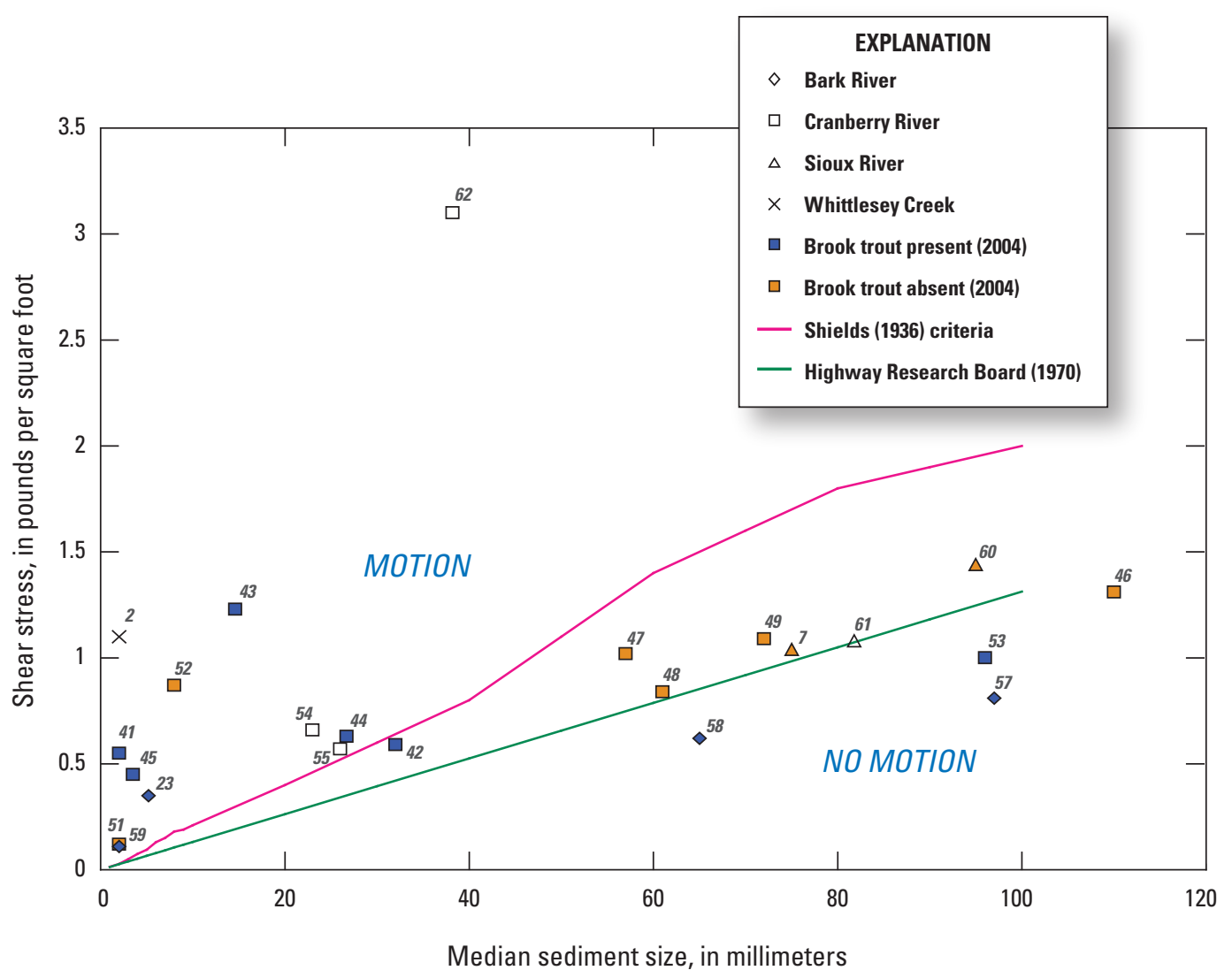

Figure 27. Bankfull-channel shear stress and median sediment size for selected sites on Bayfield streams. Curves are thresholds for motion for noncohesive quartz particles (Shields, 1936) and riprap (Highway research Board, 1970). Site numbers are on figures $1 A$ and $B$.

agricultural land cover, whereas the Sioux River basin had 10 percent and the Whittlesey Creek basin had 28.2 percent. The lower percentage of grassland and higher percentage of forest cover in the Cranberry River in 1928 offset any additional peak flow that may have been caused by the small addition of agriculture (table 5). In 1928, the Cranberry River had 2.1 percent more wetland than in 1992-93.

Results of the developed scenario indicate that if 25 percent of the forested land in the Cranberry River were to be developed into urban land, flood peaks would be expected to increase by 19 to 24 percent and runoff by 8 to 13 percent compared to flood peaks and runoff for the 1992-93 scenario (fig. 29, table 9). The time from antecedent base-flow conditions to peak flow in the developed scenario is less than in the 1992-93 scenario.

A previous flood hydrograph and sediment-transport model for North Fish Creek indicated that 1992-93 flood peaks and sediment loads for a historical flood with a 2-yr recurrence interval are twice that expected under presettlement forest cover, and during peak agriculture, 2-yr flood peaks probably were three times larger and sediment loads five times larger than expected under presettlement forest cover (Fitzpatrick and others, 1999). The flood-hydrograph model for North Fish Creek was done by use of the event-based HEC-1, similar to the modeling that was done for the Cranberry River, with a 15-minute time interval. Because overland and channel-roughness coefficients were not increased in the North Fish Creek presettlement simulation, however, presettlement flood peaks probably were lower than the simulated peaks. The North Fish Creek basin had more pasture/grassland (31 percent) and cropland (3 percent) in 1992-93 than the Cranberry River basin (7 percent pasture/grassland and 0 percent cropland).

In a previous study, simulations of flood hydrographs for Whittlesey Creek were done with the Soil and Water Assessment Tool (SWAT) (Lenz and others, 2003). SWAT is a continuous model with a mean daily time step that accounts for runoff as well as infiltration and shallow groundwater flow. Results from the Whittlesey Creek SWAT simulations indicated that changing the 1992-93 land cover to complete forest resulted in a 12-14 percent decrease in peak daily mean flow for a flood with a 100-yr recurrence interval. Changing 
Table 8. Relative contributions of sediment from seven sources to Bayfield Peninsula streams, Wisconsin.

[All data are percentages. nd, not determined]

\begin{tabular}{lccccccc}
\hline & Upland & $\begin{array}{c}\text { Road } \\
\text { crossings }\end{array}$ & $\begin{array}{c}\text { Bluffs and } \\
\text { terraces }\end{array}$ & Banks & $\begin{array}{c}\text { Incision along } \\
\text { main stem }\end{array}$ & $\begin{array}{c}\text { Feeder } \\
\text { channels }\end{array}$ & Gullies \\
\hline Cranberry River & 0 & 10 & 35 & 15 & 10 & 25 & 5 \\
Bark River & 0 & 15 & 20 & 10 & 20 & 20 & 15 \\
Raspberry River & nd & nd & nd & nd & nd & nd & nd \\
Sioux River & 5 & 5 & 50 & 10 & 15 & 10 & 5 \\
Whittlesey Creek & 5 & 5 & 55 & 10 & 10 & 10 & 5 \\
North Fish Creek (Fitzpatrick, 1998) & 5 & 0 & 67 & 6 & 18 & 0 & 4 \\
North Fish Creek (updated, this study) & 5 & 5 & 50 & 10 & 15 & 10 & 5 \\
\hline
\end{tabular}

the 1992-93 land cover to 25 percent urban land resulted in a 7-18 percent increase in peak daily mean flow. For the 1928 peak agriculture scenario, the peak daily mean flow was $0-7$ percent higher. Streamflow data from the Whittlesey streamflow-gaging station indicated that instantaneous flood peaks (based on 15-minute intervals) may be more than double flood peaks based on daily mean flow.

In summary, flood peaks for Bayfield streams are currently 1.5 to 2 times greater than before Euro-American settlement. Runoff volumes are probably similar or only slightly larger than presettlement runoff volumes. For the Cranberry River and other primarily forested, steep streams like the Bark River, increased flood peaks are most likely caused by decreases in roughness provided by forest cover and soil organic debris in overland flow areas and LWD in channels. Currently, in upland areas and valley-side slopes, the forests are generally young (less than 50 years old) and the organic debris layer on the forest floor is thin. The amount and size of woody debris in the channels likely is less then during presettlement, because the riparian forest cover is younger and smaller than before Euro-American settlement (according to presettlement accounts of fishing expeditions), and because channels were likely scoured of LWD before or during log drives in the late 1800s. For Whittlesey Creek and other basins that have more agriculture and grassland, reductions in upland roughness are caused by reductions in the age and amount of forest cover and amount of evergreen forest. Regardless of the reason for decreased roughness, if the rate of runoff from uplands is decreased and channel roughness is increased, flood peaks would be expected to decrease in all streams.

Simulation results of sediment loads for the different land-cover scenarios for North Fish Creek indicate that, if flood peaks decrease, sediment transport and sediment loads decrease (Fitzpatrick and Knox, 2001). The benefit of reducing sediment loads through a reduction in flood peaks is exponential because the empirical relation between sediment load and streamflow is best represented by power function (Fitzpatrick and Knox, 2001). Implications for geomorphic conditions are that decreasing flood peaks should reduce the potential for incision, bank erosion, bluff and terrace erosion, lateral migration, and widening. Slowing the runoff from uplands also will reduce the potential for incision of feeder tributaries that bisect the entrenched valley sides.

\section{Groundwater-Flow Characteristics}

Groundwater-flow characteristics for the Bayfield Peninsula included field measurements of base flow, a model simulation of groundwater flow to distinguish sources of base flow, and delineations of groundwater contributing areas and divides.

\section{Base Flow}

The amount of base flow in a stream is controlled by the amount of groundwater entering a stream. The amount of groundwater entering a stream, in turn, is dependent on rock and soil characteristics, rates of precipitation and evaporation, surface and subsurface relief, and the retention of water in lakes, marshes, and reservoirs (Young and Skinner, 1974). In order to compare groundwater contributions among different streams, base flow traditionally is weighted by surface-watercontributing area (Young and Skinner, 1974). The overall distribution of unit-area base flow (base flow divided by surfacewater-contributing area) in the five Bayfield Peninsula streams is complex and ranges from $0.00\left(\mathrm{ft}^{3} / \mathrm{s}\right) / \mathrm{mi}^{2}$ in the Raspberry River to $4.00\left(\mathrm{ft}^{3} / \mathrm{s}\right) / \mathrm{mi}^{2}$ in the Bark River (fig. 30, table 10). The peninsula-wide average based on previous studies is $0.30\left(\mathrm{ft}^{3} / \mathrm{s}\right) / \mathrm{mi}^{2}$ or roughly $4.1 \mathrm{in} / \mathrm{yr}$ (Young and Skinner, 1974).

Unit-area base flow is high in streams downstream from where the channels intersect the regional aquifer system. The exact location of this intersection is dependent on the 

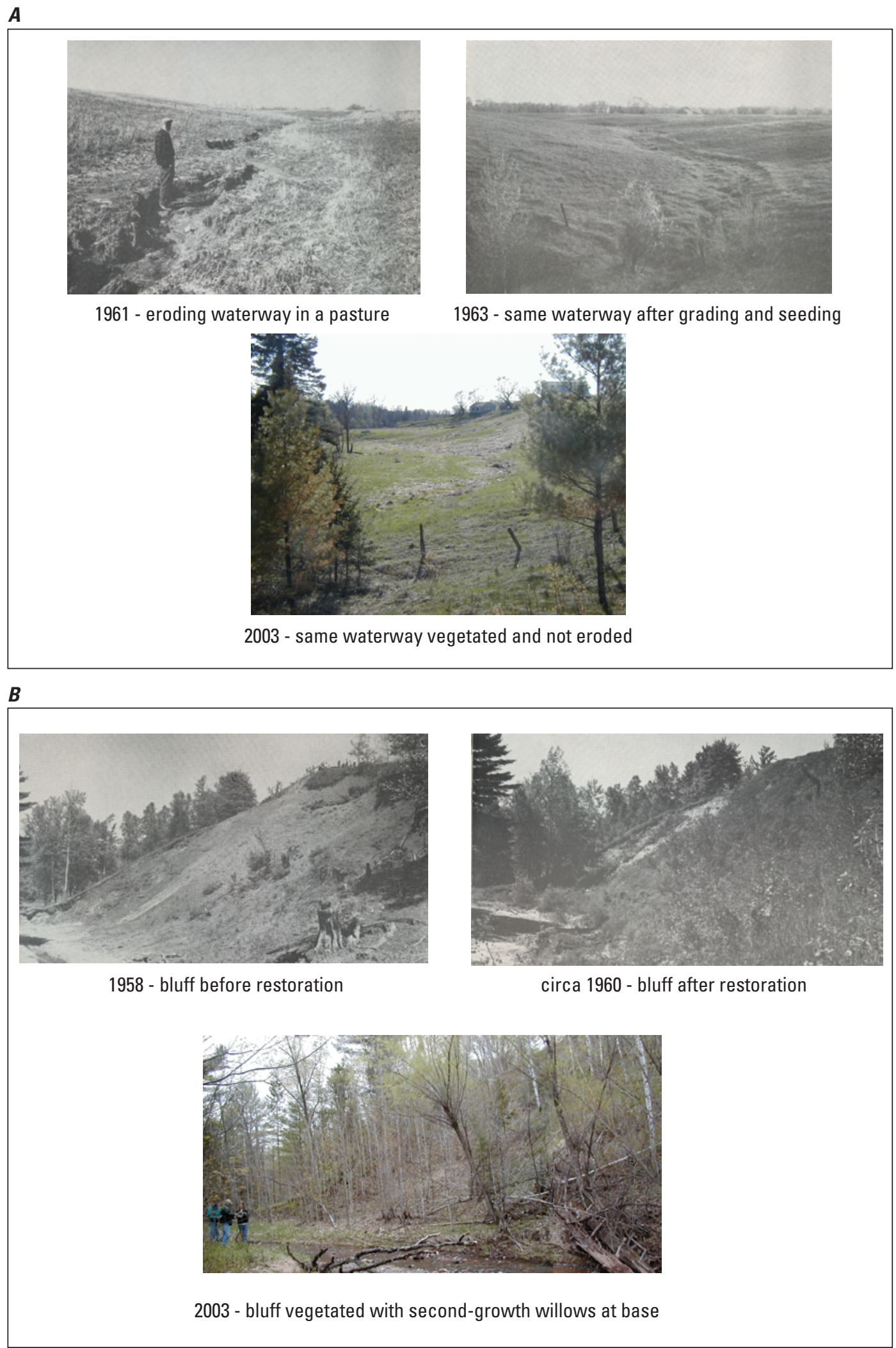

Figure 28. Two Red Clay Interagency Committee sites before and after installation of erosion-control techniques: $A$, South Fish Creek waterway (site 65), and $B$, Whittlesey Creek bluff (site 66). 
Table 9. Flood peaks and total storm volume from SCS-design storms for HEC-1 flood hydrograph simulations of four land-cover scenarios, Cranberry River, Wisconsin.

[\%, percent; yr, year; $\mathrm{ft}^{3} / \mathrm{s}$, feet per second; —, not applicable; in., inches]

\begin{tabular}{|c|c|c|c|c|c|c|c|c|c|c|c|c|}
\hline & \multicolumn{3}{|c|}{$1992-93$} & \multicolumn{3}{|c|}{ Presettlement (before 1870) } & \multicolumn{3}{|c|}{ Peak agriculture (1928) } & \multicolumn{3}{|c|}{ Developed (25\% urban) } \\
\hline & $100-y r$ & $10-y r$ & $2-y r$ & $100-y r$ & $10-y r$ & $2-y r$ & $100-y r$ & $10-y r$ & 2-yr & $100-y r$ & 10-yr & 2-yr \\
\hline $\begin{array}{l}\text { Maximium peak } \\
\text { flow }\left(\mathrm{ft}^{3} / \mathrm{s}\right)\end{array}$ & 7,980 & 3,760 & 1,610 & 5,100 & 2,430 & 1,100 & 7,580 & 3,650 & 1,670 & 9,810 & 4,740 & 2,110 \\
\hline $\begin{array}{c}\text { Difference from } \\
\quad 1992-93(\%)\end{array}$ & - & - & - & -57 & -55 & -46 & -5 & -3 & 4 & 19 & 21 & 24 \\
\hline $\begin{array}{l}\text { Total watershed } \\
\text { runoff (in.) }\end{array}$ & 2.56 & 1.25 & 0.56 & 2.45 & 1.20 & 0.56 & 2.48 & 1.23 & 0.57 & 2.78 & 1.39 & 0.65 \\
\hline $\begin{array}{c}\text { Difference from } \\
\text { 1992-93 (\%) }\end{array}$ & - & - & - & -5 & -4 & -1 & -3 & -2 & 2 & 8 & 10 & 13 \\
\hline
\end{tabular}

proximity of the channel to the groundwater contributing area and the location and distribution of underlying coarse-grained deposits (fig. 30). The regional aquifer system intersects Whittlesey Creek at about $650 \mathrm{ft}$ (fig. 6). Upstream from about $710 \mathrm{ft}$ in Whittlesey Creek, base flow is negligible (Lenz and others, 2003). Thus, unit-area base flow in Bayfield streams may increase disproportionately from the headwaters and upper main stem to middle and lower main stems. For the Sioux River and Bark River, the main gain in base flow also is near $650 \mathrm{ft}$. Unit-area base flows remain low in the Raspberry River along its entire length. Unit-area base flows are high along the entire East Fork of the Cranberry River. For North Fish Creek, springs fed by the regional aquifer system are along the channel from altitudes of about 650 to $900 \mathrm{ft}$. Thus, the unit-area base flow of $1.35\left(\mathrm{ft}^{3} / \mathrm{s}\right) / \mathrm{mi}^{2}$ at the North Fish Creek streamflow-gaging station is high and increases slightly at the mouth to $1.6\left(\mathrm{ft}^{3} / \mathrm{s}\right) / \mathrm{mi}^{2}$ (Lenz and others, 2003). Sections of streams with brook trout (fig. 2) have relatively high unit-area base flows.

Comparison of base flow in Cranberry River tributaries illustrates the importance of proximity of a basin to the surface-water noncontributing area (fig. 30). The East Fork of the Cranberry River at site 32 (fig. $1 B$ ) has a unit-area base flow of $3.06\left(\mathrm{ft}^{3} / \mathrm{s}\right) / \mathrm{mi}^{2}$ and Lenawee Creek at site 33 has a unit-area base flow of $0.37\left(\mathrm{ft}^{3} / \mathrm{s}\right) / \mathrm{mi}^{2}$. The subbasins have similar drainage areas and land cover. The headwaters of the East Fork of the Cranberry River are surrounded on two sides by the surface-water noncontributing area and drain the postglacial outwash valley that contains coarse-grained deposits (fig. 4). On the eastern side of the peninsula, Fourmile Creek at site 6 is similarly situated and has more base flow than the Little Sioux River at site 9 and the main stem of the Sioux River at site 4.

\section{Groundwater-Flow Simulation}

Simulation of groundwater flow was used to distinguish sources of base flow for all the Bayfield Peninsula streams. An initial GFLOW model for the Bayfield Peninsula was developed by modifying an existing GFLOW model that was constructed for a hydrologic study of Whittlesey Creek (Lenz and others, 2003). The initial model was refined, tested for parameter sensitivity, and automatically calibrated by using the computer program UCODE. Initial and optimized model parameters for the Bayfield Peninsula GFLOW model are listed in table 11. A summary of head and base flow statistics for the initial and calibrated GFLOW model is shown in table 12 .

The initial GFLOW model for the Bayfield Peninsula was modified from the existing Whittlesey Creek GFLOW model in the following ways: (1) The nearfield area was expanded to include the entire peninsula from the Flag River to North Fish Creek; (2) The new nearfield linesinks were updated with more detailed, improved data for stream altitudes, streambed resistance, and streamflow routing; (3) The stepped-base altitude for the area underlain by the Copper Falls Formation was removed and replaced with a uniform-base altitude for the entire model area (the hydraulic conductivity $(\mathrm{K})$ for this area was decreased to produce the same transmissivity as that in the stepped model); and (4) The inhomogeneity representing the Miller Creek Formation was divided into two zones, one for the north and west parts of the peninsula and one for the east part. Horizontal hydraulic conductivity $\left(\mathrm{K}_{\mathrm{h}}\right)$ for the north and west zone was anticipated to be $10 \mathrm{ft} / \mathrm{d}$ lower than $\mathrm{K}_{\mathrm{h}}$ for the east zone. The $\mathrm{K}_{\mathrm{h}}$ for the east side zone was maintained at the original value of $34 \mathrm{ft} / \mathrm{d}$ from the Whittlesey model. Except for the lower value of $\mathrm{K}_{\mathrm{h}}$ used in the north and west side inhomogeneity zone, this initial GFLOW model used the same parameter values for $\mathrm{K}$ and recharge as the existing 

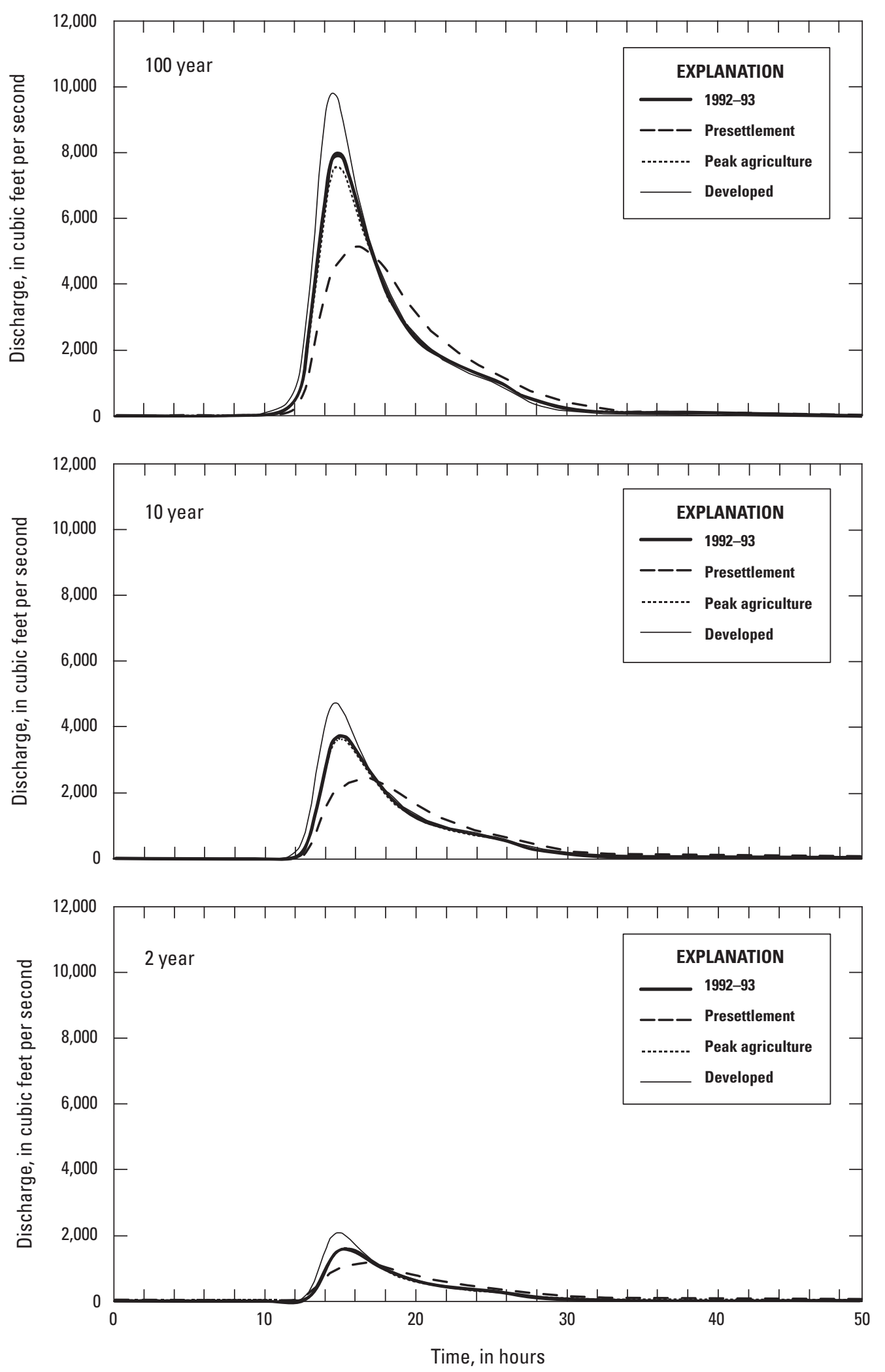

Figure 29. Flood hydrographs for the 2-, 10-, and 100-year 24-hour rainfalls for the Cranberry River, Wisconsin. Rainfall data from Huff and Angel (1992). Rainfall volumes were distributed by using the SCS type-II rainfall distribution (Soil Conservation Service, 1972). 


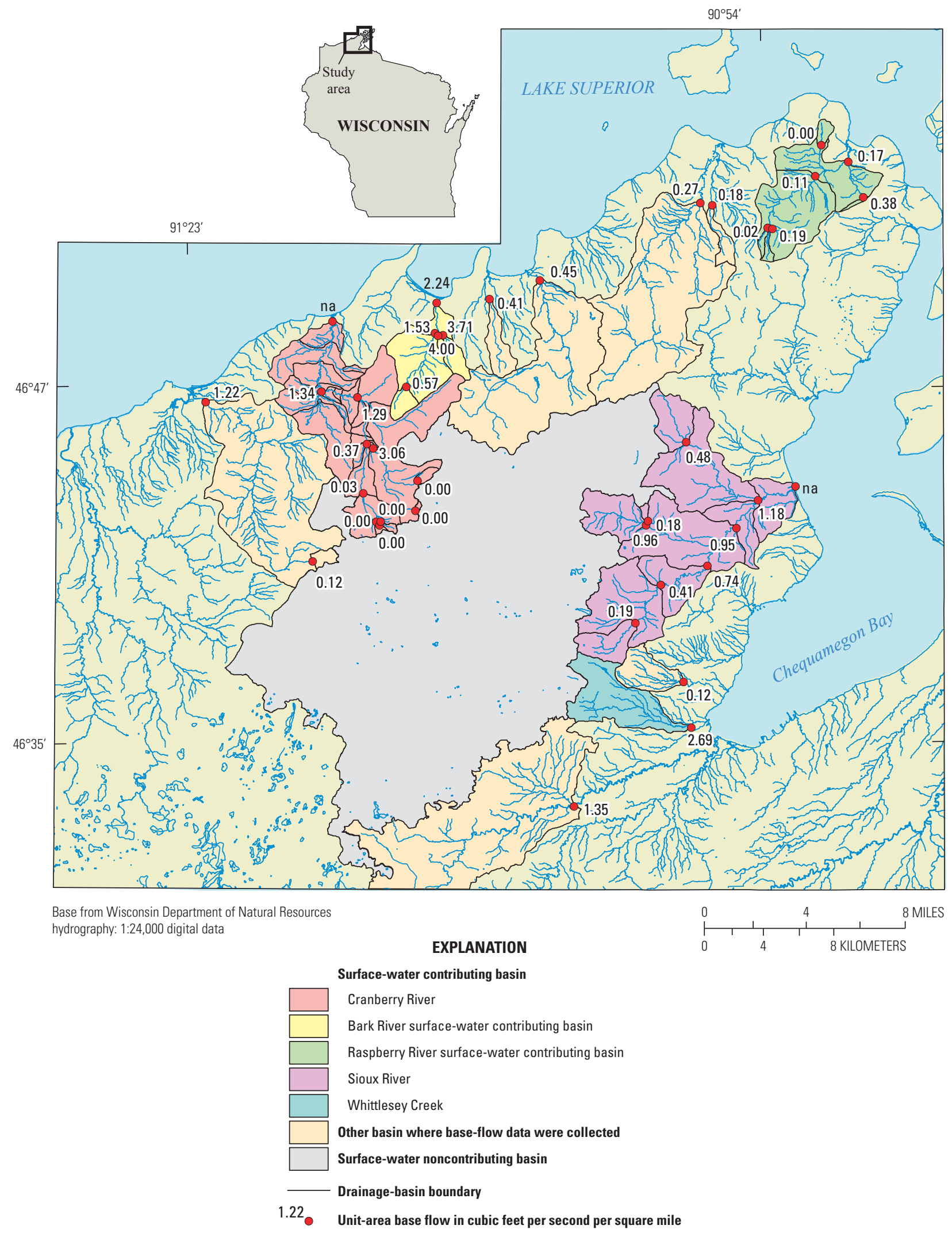

Figure 30. Distribution of unit-area base flow for streams on the Bayfield Peninsula, Wisconsin, November 2002. 
Table 10. Results of field investigations of base flow and streambed temperature for Bayfield Peninsula streams, Wisconsin, 2002.

[USGS, U.S. Geological Survey, $\mathrm{mi}^{2}$, square miles, $\mathrm{ft}^{3} / \mathrm{s}$, feet per second; ${ }^{\circ} \mathrm{C}$, degrees Celsius; Wis., Wisconsin; na, not applicable; nd, not determined; Rd., road; Cty., County; Hwy., Highway; Trib., tributary; S., South; E., East]

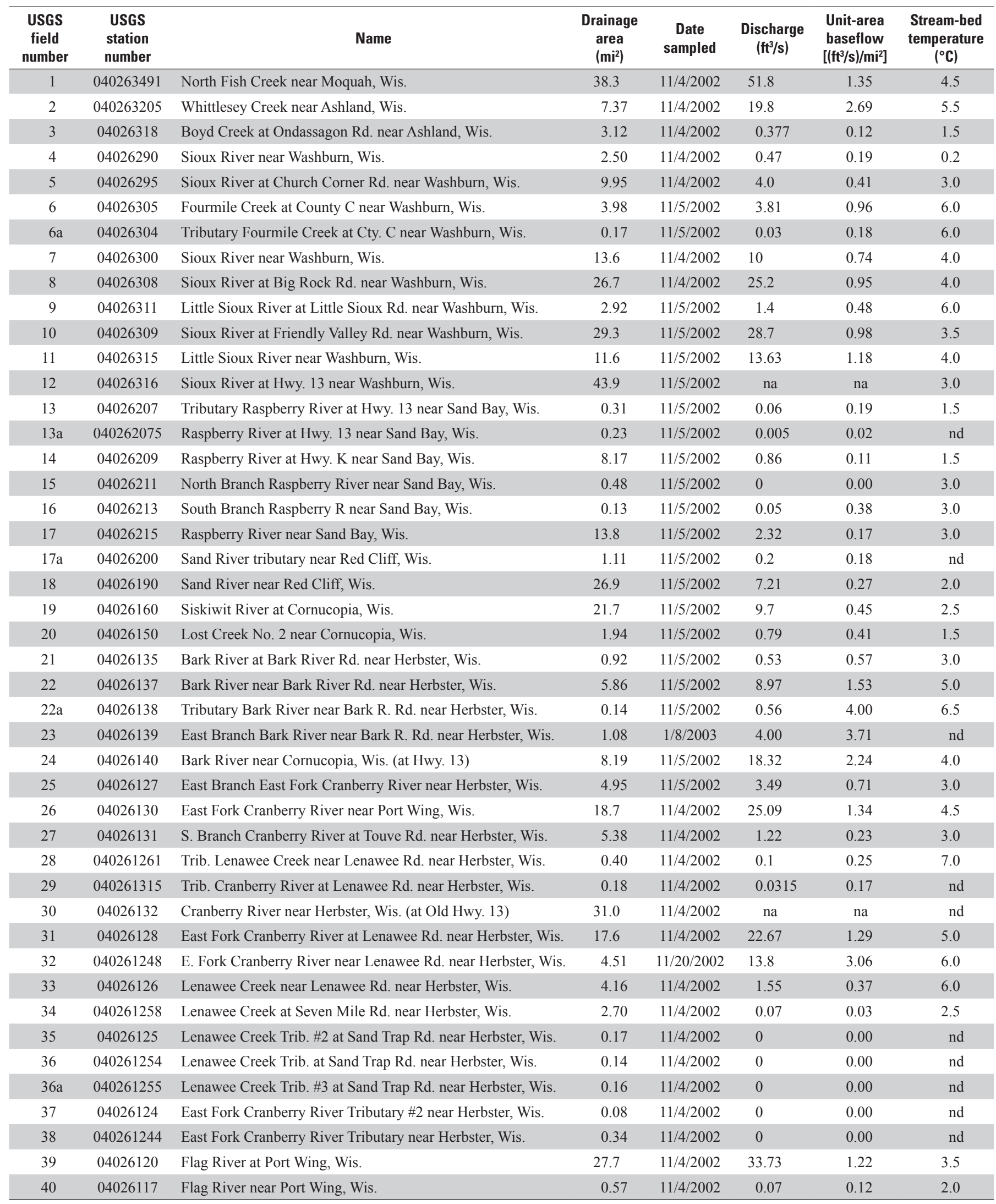


Table 11. Initial estimate and UCODE-optimized parameters used in the GFLOW model for Bayfield Peninsula, Wisconsin.

$\left[\mathrm{K}_{\mathrm{h}}\right.$, horizontal hydraulic conductivity; Fm, Formation ; ft/d, feet per day; in/yr, inches per year; ft, feet]

\begin{tabular}{lcc}
\hline \multicolumn{1}{c}{ Parameter } & \multicolumn{2}{c}{ UCODE } \\
\cline { 2 - 3 } & Initial estimate & Optimized value \\
\hline $\mathrm{K}_{\mathrm{h}}$ Copper Falls Fm & $46.5 \mathrm{ft} / \mathrm{d}$ & $47.8 \mathrm{ft} / \mathrm{d}$ \\
$\mathrm{K}_{\mathrm{h}}$ Miller Creek Fm (east side) & $34.4 \mathrm{ft} / \mathrm{d}$ & $23.6 \mathrm{ft} / \mathrm{d}$ \\
$\mathrm{K}_{\mathrm{h}}$ Miller Creek Fm (north/west side) & $10 \mathrm{ft} / \mathrm{d}$ & $6.9 \mathrm{ft} / \mathrm{d}$ \\
Recharge through Copper Falls Fm & $17 \mathrm{in} / \mathrm{yr}$ & $13.6 \mathrm{in} / \mathrm{yr}$ \\
Recharge through Miller Creek Fm (east side) & $2 \mathrm{in} / \mathrm{yr}$ & $3.5 \mathrm{in} / \mathrm{yr}$ \\
Recharge through Miller Creek Fm (north/west side) & $2 \mathrm{in} / \mathrm{yr}$ & $2.1 \mathrm{in} / \mathrm{yr}$ \\
Model layer bottom altitude & $550 \mathrm{ft}$ & $526 \mathrm{ft}$ \\
Lake Superior linesink resistance & $100 \mathrm{days}$ & $100 \mathrm{days}$ \\
Stream linesink resistance & 2 & $0.01-10 \mathrm{days}$ \\
\hline
\end{tabular}

${ }^{1}$ Parameter not optimized because of model insensitivity.

${ }^{2}$ Parameter not tested for sensitivity.

Table 12. Head fit statistics and sum of square weighted residuals for the initial and calibrated GFLOW model for Bayfield Peninsula, Wisconsin.

[ft, feet; RMS, root mean square]

\begin{tabular}{lccccc}
\hline $\begin{array}{c}\text { Simulation } \\
\text { description }\end{array}$ & $\begin{array}{c}\text { Mean absolute } \\
\text { difference (MAD), } \\
\text { head (ft) }\end{array}$ & $\begin{array}{c}\text { RMS error, } \\
\text { head } \\
\text { (ft) }\end{array}$ & $\begin{array}{c}\text { Error range, } \\
\text { head } \\
\text { (ft) }\end{array}$ & $\begin{array}{c}\text { Sum of square } \\
\text { weighted residuals } \\
\text { for all targets }\end{array}$ & $\begin{array}{c}\text { Sum of square } \\
\text { weighted residuals } \\
\text { for base flow }\end{array}$ \\
\hline GFLOW, initial & 18.4 & 21.9 & -39.4 to 48.3 & 1,558 & 695 \\
GFLOW, calibrated & 18.4 & 22.5 & -49.4 to 48.4 & 1,487 & 573 \\
\hline
\end{tabular}

$\boldsymbol{A}$

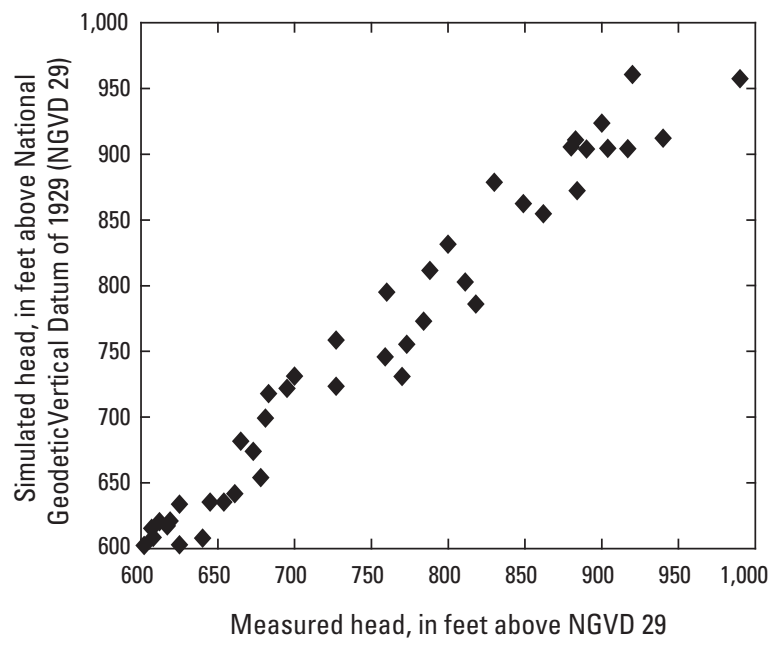

B

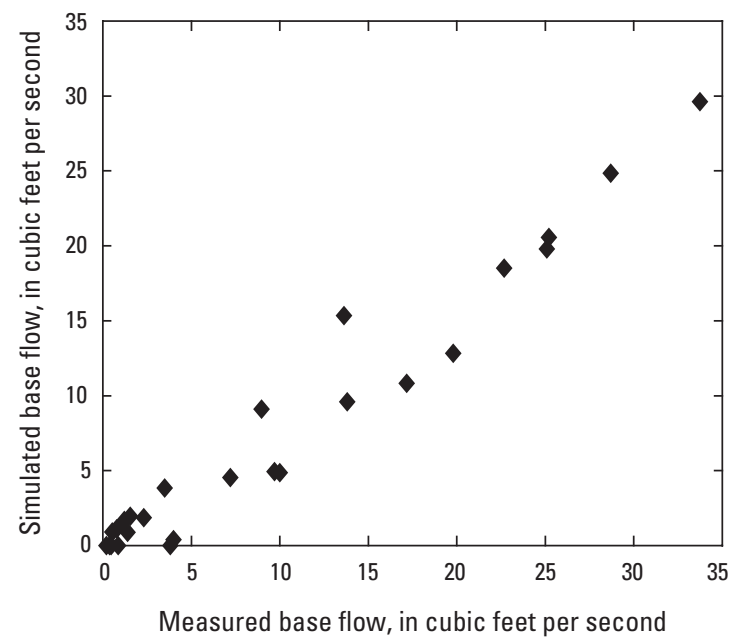

Figure 31. Relation of measured and simulated $A$, head and $B$, base flow for the calibrated GFLOW model for Bayfield Peninsula, Wisconsin. 
GFLOW model for Whittlesey Creek (table 11). The removal of the stepped-base altitude made the simulated saturated thickness of the area underlain by the Copper Falls Formation about $150 \mathrm{ft}$ thicker (increased from approximately $300 \mathrm{ft}$ for the stepped base altitude to about $450 \mathrm{ft}$ for the uniform-base altitude). To account for this change in thickness, the initial $\mathrm{K}_{\mathrm{h}}$ for the Copper Falls Formation was changed from 69.8 to $46.5 \mathrm{ft} / \mathrm{d}$ in the GFLOW model's inhomogeneity attribute. This change results in a transmissivity similar to that used in the Whittlesey Creek model for the area underlain by the Copper Falls Formation.

The mean absolute difference (MAD) between simulated and measured head was $18.4 \mathrm{ft}$, and the total sum of squared weighted residuals for all targets was 1,558 (with 695 from base flow targets alone) for the initial GFLOW model (table 12, fig. 31). In general, the initial GFLOW model simulated heads and base flows reasonably well throughout the peninsula. Simulated base flows were similar to measured base flows near river mouths; however, there were several headwater locations where the model indicated no base flow when actual flows, on the order of $0.2-4 \mathrm{ft}^{3} / \mathrm{s}$, were measured in the field. This is likely because of the simplifying assumptions used in the model and the accuracy of the elevation data used for simulated streams. This discrepancy was particularly noticeable in the vicinity of the Sioux River headwaters.

Input parameters for the initial GFLOW model were evaluated for model sensitivity by means of UCODE (fig. 32). The model was most sensitive to recharge through the Copper Falls Formation (composite-scale sensitivity $=56.9$ ), followed by the model-layer bottom altitude (26.3), and $\mathrm{K}_{\mathrm{h}}$ of the Miller Creek Formation on the east side of the peninsula (22.8). The model was least sensitive to resistance of the Lake Superior linesink (0.806). [The Lake Superior linesink resistance parameter was not optimized by using UCODE.]

After calibration and optimization, the UCODEoptimized input parameters were only slightly changed from initial values (table 11). With the optimized parameter values from UCODE, the MAD between simulated and measured head for the calibrated GFLOW model was $18.4 \mathrm{ft}$ and the total sum of squared weight residuals was 1487 (with 573 from base-flow targets alone) (table 12). Simulated heads remained relatively unchanged in the calibrated model, whereas base flows were slightly improved. Even with the slight base-flow improvement, several flowing headwater reaches of the Sioux River were still simulated as dry. It should be noted that the GFLOW model described here is a simplified version of a complex groundwater system. The groundwater system is simulated by using a single layer model and some groundwater does likely flow through parts of the system that are deeper than that represented by the model. Calibration and simulation of base flow in headwater reaches of streams might be improved with additional inhomogeneity zones in the GFLOW model or a more complex three-dimensional model.

\section{Groundwater Divide and Groundwater Contributing Areas}

Results from the calibrated GFLOW model were used to delineate the location of the groundwater divide between the east and west sides of the peninsula as well as the groundwater contributing areas for the streams of interest. Groundwater pathlines were simulated by using the particle-tracking options of GFLOW.

To delineate groundwater contributing areas, an array of particles were tracked forward from recharge areas to discharge locations at the streams of interest. Particle movement to the east and west indicated the location of the divide (fig. 33). The land-surface area projected from the volume of aquifer encompassing the pathlines for a particular stream represents the groundwater contributing area for that stream (fig. 33). Groundwater contributing areas ranged in size from $9.6 \mathrm{mi}^{2}$ for the Raspberry River to $62.9 \mathrm{mi}^{2}$ for the Sioux River. Particle-tracking results indicated that the groundwater contributing areas generally did not coincide with the delineated surface-water contributing areas. For Whittlesey Creek, average travel time for particles was 215 years; the median travel time was about 94 years (Lenz and others, 2003).

The GFLOW model estimated an average of $304\left(\mathrm{ft}^{3} / \mathrm{s}\right) / \mathrm{yr}$ of recharge for the Bayfield Peninsula, with $230\left(\mathrm{ft}^{3} / \mathrm{s}\right) / \mathrm{yr}$ (76 percent) from the area underlain by the sandy Copper Falls Formation. On the basis of base-flow measurements (table 10) and estimates from the GFLOW model, about 89 percent of total recharge discharges to Bayfield Peninsula streams; the remaining 11 percent discharges to Lake Superior.

The effects of changes in land cover on groundwater recharge or discharge were not evaluated for this study; however, results from a previous groundwater-flow model done for Whittlesey Creek (Lenz and others, 2003) indicated that changing the total recharge in the entire groundwater contributing area by 25 percent (an extreme case) resulted in a change of about 6 percent in base flow. In addition, changing the recharge in an individual groundwater contributing area changed the boundaries of the groundwater contributing area. For example, when a decrease in recharge was simulated in the Whittlesey Creek groundwater contributing area, a depression in the potentiometric surface formed that resulted in an expansion of the groundwater contributing area (at the expense of contributing areas for adjacent streams), which in turn limited the decrease in base flow because of the decreased recharge. If trees were absent from the sandy groundwater contributing area of Whittlesey Creek, evapotranspiration would be less, and there would likely be an increase in recharge of possibly 25 percent. This would potentially cause an increase in base flow to Whittlesey Creek of about 4 percent (Lenz and others, 2003). 


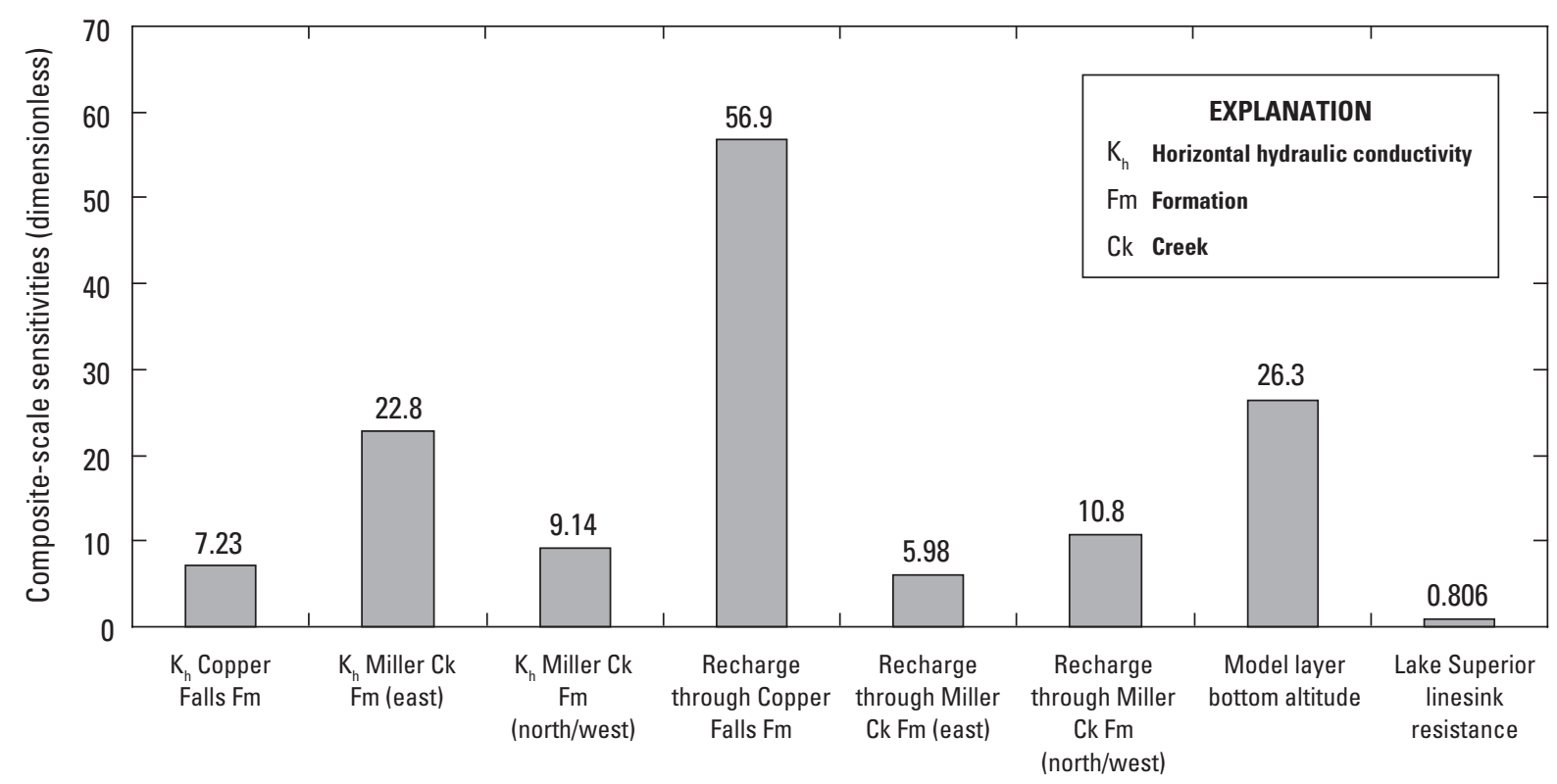

Figure 32. GFLOW groundwater-flow model parameter sensitivities from UCODE for the Bayfield Peninsula, Wisconsin study area. Kh is horizontal hydraulic conductivity; Fm, Formation; Ck, Creek.

\section{Implications for Brook-Trout Habitat}

All five of the studied streams were described as important brook trout streams in local newspapers during the 1870 s and 1880s. Although initial declines in brook-trout populations in the late 19th century were attributed to angler and commercial overharvesting, land-cover changes were soon implicated. Human-induced landscape changes have long been noted to cause broad declines in brook-trout populations over their historical range. As early as 1900 , a federal document noted that land-cover changes were influencing brook trout by stating that "owing to the clearing of the lands at the sources of the streams, which has produced changed conditions in and along waters not agreeable to brook trout's wild nature" (Bowers, 1900). A more direct statement in a U.S. Bureau of Fisheries document implicated surface runoff changes: “... through the cutting away of forests and the cultivation of the land, many streams in the eastern part of the United States have become unsuited to brook trout" (Leach, 1923). By the 1930s, Wisconsin scientists began noting that critical brook-trout habitat had been affected by surface runoff, log-transport activities and sedimentation. For example, a Wisconsin fish biologist noted "Deforestation with its concomitant effects upon water supply, lowering and warming of the waters, scouring of the stream beds by the logs and especially the silting over of gravel bottoms had done much to lessen the productivity of trout waters" (Greene, 1935).
Brook trout have a narrow tolerance window regarding their habitat needs. The four major habitat components are water quality/temperature, spawning and egg incubation, cover, and food production (Pratt, 2000). Moderate water temperatures are best, neither too warm in summer or too cold (freezing) in winter. Stable substrates are needed for spawning and egg incubation. Cover near food is important after fry emerge from spawning gravels until the fingerlings reach about 2 in. in length. Brook trout hatch in early spring from spawning beds on small-size gravel near groundwater upwelling (Newman and others, 1996).

The most limiting factor in present-day brook-trout populations in Bayfield streams seems to be poor survival from the time the egg is laid to the time the young fingerlings are about 2 in. in length. Spawning beds (redds) may be scoured or mobilized during floods in upper and middle main stems and tributaries and buried by sand in lower reaches. Many of the largest floods resulted from rainfall combined with snowmelt from mid-March to early May. Early spring floods are especially hard on the fry. LWD provides cover and substrate for juveniles and adults and serves as attachment sites for aquatic insects. Juveniles can easily be swept downstream during floods if there are no LWD refugia (Wisconsin Natural Resources and U.S. Fish and Wildlife, 2005). Groundwater upwelling areas may be buried in sand. Suitable pool habitat in downstream reaches may be filled in with sand. Filling of pools minimizes winter pool cover-deep water is needed to survive winter freezes. Sand bed load negatively affects 


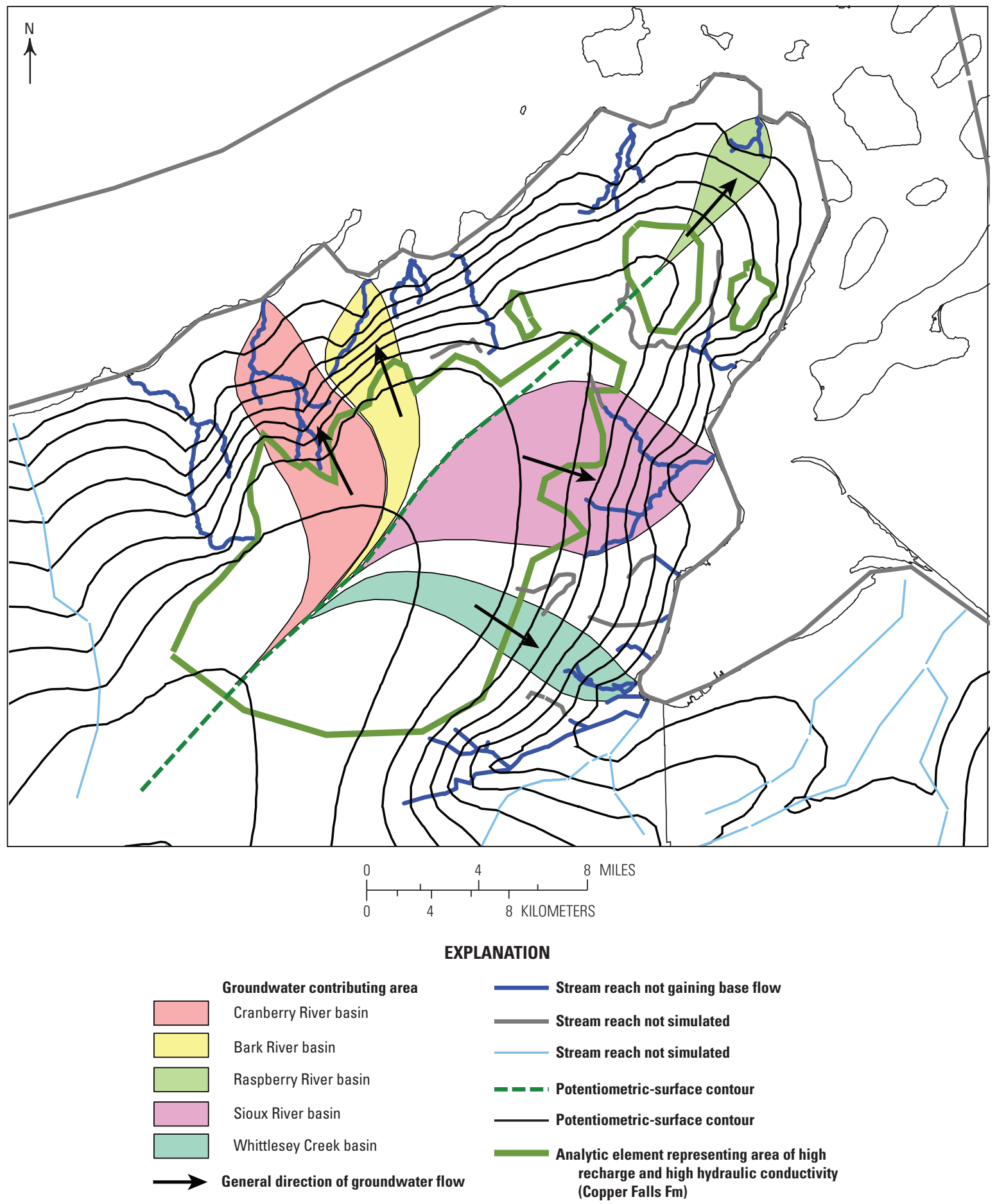

Figure 33. Groundwater contours and contributing areas simulated by the GLFOW model for five Bayfield Peninsula streams, Wisconsin. 
spawning habitat, incubation success, emergent success, and living space quality.

The reduced brook-trout fishery in Bayfield streams is the direct result of geomorphic responses to increased runoff and flood peaks. Beginning in the late 1800s, logging, forest fires, and settlement activities reduced watershed storage, interception, infiltration, upland and channel roughness; shortened drainage pathways; and increased overland runoff rates and flood peaks. Surface runoff, flood peaks, erosion, and sedimentation reached their highest levels during the 1940s and 1950s, corresponding to a period of large, frequent floods (Fitzpatrick and Knox, 2001). Floods during this period enlarged channel cross sections, and caused incision, scour, and transport of sand, gravel, and LWD. Flood peaks and resulting incision, bank erosion, and sedimentation decreased after about 1960 at the same time as reforestation and decreases in row-crop agriculture. Presently, flood peaks are still higher than presettlement peaks. Geomorphic responses to increased runoff rates and flood peaks are (generally from upstream to downstream): (1) incision in headwaters, (2) incision or bluff erosion in upper main stems, (3) local aggradation and excessive sand sedimentation in reaches with beaver activity or poorly constructed road crossings, (4) increased erosion of bluffs, terraces, and banks and unstable gravel-bar formation along upper or middle main stems, (5) transport of sediment from upper and middle main stems to lower main stems, (6) increased incision in feeder tributaries to main-stem channels, (7) loss of flood-plain storage in upper and middle main stems, (8) stream widening and pool filling in middle and lower main stems, and (9) aggradation in lower main stems.

LWD in streams can provide important controls on the formation and physical characteristics of pools, bars and steps, and can influence channel type, sediment storage, and channel roughness (Montgomery and Buffington, 1997). In the past, an extensive amount of wood debris characterized all streams described in historical accounts. Abundant LWD provided habitat diversity, protection from floods, increased gravel storage, and spawning-site stability (Wisconsin Department of Natural Resources and U.S. Fish and Wildlife Service, 2005). The combination of direct removal (log-driving era) and the young age and composition of present-day riparian forests leading to sparse LWD, along with increased flood peaks and channel incision in the upper to middle main stems, has resulted in unstable streambeds and the flushing of gravel of the most critical size for brook trout spawning.

Sand entering stream channels degrades brook-trout success by burying essential remaining spawning habitat and food sources. Sand-sized particles plug the interstitial spaces between the gravel, which suffocates incubating eggs and blocks fry emergence. Brook trout are very susceptible to these losses because they choose low-velocity areas as spawning sites. An experiment in a Michigan trout stream where sand was added to a stream reduced brook-trout numbers by half and severely degraded stream habitat (Alexander and Hansen, 1986). The population decrease was attributed to poor survival rates, particularly in the egg-to-fry and fry-to-fall-fingerling stages of life cycle. In that study, the addition of the sand caused the channel to widen, become shallower, and have less pool habitat. Historical newspaper accounts described deep pools in lower main stem reaches. Scoured-sand deposits from log drives and large flood peaks have since buried the pools and reduced habitat quality.

The degradation of critical brook-trout habitat in Bayfield streams has resulted in small counts of brook trout in middle to lower main stems. The present-day brook-trout populations are confined to small reaches with groundwater upwelling and relatively low stream power. These reaches are mainly in upper main stems or feeder tributaries. Beaver activity in these reaches is common and causes local aggradation and sand deposition in critical spawning areas.

Whether watershed- or site-specific, rehabilitation techniques are geared toward reducing runoff from upland areas and erosion from upper and middle main stems and feeder channels, with the goal of stabilizing gravel beds, reducing sand bed load, increasing habitat diversity, the amount of pool habitat, and cover and food production. The streams represent dynamic geomorphic systems that drain a steep landscape with clayey soils. Thus the main goals for the rehabilitation efforts, in recognition of this dynamic nature, are to reduce flood peaks and sediment loads so that they are similar to presettlement conditions, rather than to hold the channels in one location or reduce sediment loads to zero.

The study of Bayfield streams by Inter-Fluve, Inc. and Graber (2003) made several recommendations for management activities that could improve brook-trout habitat. The recommendations were based on an understanding of the watershed and of longitudinal connections among sediment transport and geomorphic processes. They include watershedmanagement practices that reduce runoff from uplands and flow rates in tributaries and increase upland roughness. Sitespecific techniques are tailored to decrease incision and stream power, decrease gullying, stabilize eroding bluffs and terraces, and increase channel roughness. Previous techniques used by the RCIC to control erosion and incision in pastured feeder channels (grassed waterways) and stabilize bluffs (combination of bioengineering and hard structures) are useful examples for future rehabilitation efforts.

Inter-Fluve, Inc. and Graber's (2003) watershed recommendations include adherence to Wisconsin's Administrative Code NR115 for riparian management zones along perennial streams. In addition, they recommend no timber harvesting within a primary buffer of $50 \mathrm{ft}$ and limited selective cutting within a secondary 300 -ft buffer on intermittent, nonnavigable headwater reaches. They recommend that forest cover be preserved near headwater channels and that land in these areas be enrolled in conservation easements or landpurchase programs so that mature forest cover is maintained. For riparian zones, white pine and hemlock restoration was suggested to increase LWD recruitment. Engineered log jams were suggested as possible means to increase channel roughness in stream reaches with incision and high stream power. 
Detention basins can decrease flood peaks but do not reduce runoff volumes (Fitzpatrick, 1998; Fitzpatrick and others, 1999). Inter-Fluve, Inc. and Graber (2003) noted that detention basins may increase water temperature. In the North Fish Creek model, the flood hydrograph for the watershed lasted about 40 hours with detention basins compared to about 15 hours for 1992-93 land cover and 25 hours for the presettlement scenario. The base-flow survey results and groundwater-flow model from this study and Lenz and others (2003) indicate that groundwater upwellings are along main stem reaches; thus, ephemeral headwater channels and tributaries are generally not the main sources for cold water for Bayfield streams. Detention basins as a technique for slowing flow may be applicable in areas where it is not possible to maintain a mature forest. Infiltration basins offer an alternative that could decrease flood peaks and runoff volumes without the potential impacts from warming. Unlike detention basins, infiltration basins have permeable bottoms that allow water to sink into the ground rather than to run off.

During the field investigation for this study, another source for increased runoff became apparent. Abandoned farm fields (a large part of the grassland category in the 1992-93 land cover) with extensive systems of improved drainage ditches are abundant throughout all the basins except the Bark River basin, which did not have as much agricultural development historically as did the other four studied streams. Many of these abandoned fields are now public lands, held in public trust, or owned by landowners who are not farmers and are interested in having aesthetically pleasing landscapes that attract wildlife. Even though the fields are abandoned, the drainage ditches still are serving their original purpose. Examples of these ditches are shown on the aerial photograph (fig. 20A) of the fields to the south of site 46 . Removal of the drainage networks from abandoned fields would reduce runoff from uplands.

The percentages of contributions of sediment from different sources shown in table 8 can be used with the critical brook-trout reaches shown in figure 2 to prioritize management decisions regarding brook-trout habitat. The priority of managing a particular sediment source is dependent on the source's proximity to reaches that could provide current and future habitat as well as on the source's relative contribution to the total sediment load. For example, unimproved road crossings on the upper main stem may contribute only a small amount of sediment to downstream reaches, but may locally affect a high-quality spawning area in the vicinity of the road crossing. Bluff and terrace erosion along meander cuts in the Sioux River are in spawning reaches. Adequate stream power is needed to maintain gravel bars and keep them from becoming buried with sand. Bank erosion along the lower main stem is downstream of most spawning areas and the source for the majority of the sand is from upstream bluff and terrace erosion.

\section{Summary and Conclusions}

The U.S. Geological Survey (USGS) conducted a study of the geomorphic, flood, and groundwater-flow characteristics of five Bayfield Peninsula streams from 2002 to 2003 through cooperative efforts with the Wisconsin Department of Natural Resources, Trout Unlimited, and Inter-Fluve, Inc. with the purpose of determining the link between these characteristics and the physical requirements of brook trout. The project findings were used to provide a better understanding of the physical limitations for rehabilitation of brook trout and to provide background information for water-resources and fisheries managers in their efforts to reduce runoff and erosion and improve fish habitat. The five studied streams were the Cranberry River, Bark River, Raspberry River, Sioux River, and Whittlesey Creek. The goals of the USGS part of the study of the five Bayfield streams included: (1) comparing the geomorphic characteristics of the five streams described in this study to the results of previous studies done on North Fish Creek by the USGS; (2) expanding the understanding of the causes for present and historical geomorphic processes; (3) identifying major sources of sediment; (4) describing how land-cover characteristics affect flood peaks in different streams; and (5) describing how regional groundwater flow patterns affect base flow. The study built upon previous USGS studies, including a geomorphic and flood study of North Fish Creek done in the mid-1990s, and a rainfall-runoff and groundwaterflow study of Whittlesey Creek done in 1999-2001. The study also complemented a geomorphic and hydrologic assessment of the same five streams by Inter-Fluve, Inc. that was done in 2003.

Geomorphic characteristics and processes for the five studied streams were dependent on longitudinal position within the drainage network. Geomorphic processes are also controlled by the texture of glacial deposits, proximity to postglacial-lake shorelines, and by historical changes in forest cover on uplands and valley-side slopes. These changes have increased runoff by decreasing roughness and ultimately increasing flood peaks in main-stem channels. Moreover, historical log drives combined with lack of large trees in riparian zones have likely caused a long-term lack of large woody debris in channels and consequently decreased channel roughness and increased flood peaks.

Although most upland area is forested, flood peaks are still 1.5 to 2 times larger than presettlement flood peaks, most likely because the forest cover and soils and channels are not the same as before Euro-American settlement. Forests are generally young, the duff layer is thin, ditches may be present, channels are entrenched, and upland and channel roughness are less. The increased flood peaks potentially increase shear stress and have caused increased incision along upper main stems and feeder tributaries along valley sides, bluff and terrace erosion along reaches with entrenched valleys, overbank deposition and bar formation in middle and lower main stems, and aggradation in mouth areas. The Whittlesey Creek basin has the most evidence for erosion, and the Bark River basin 
has the least. The Bark River has had the most historical and present forest cover and the shortest steep stream segment and smallest drainage area of the five studied streams.

Sediment sources were mainly from channel erosion (incision, bluff, terrace, and bank erosion) along main-stem reaches and feeder tributaries with entrenched-valley side slopes rather than from upland erosion. The basins of Whittlesey Creek and the Sioux River had similar amounts of bluff and terrace erosion as the North Fish Creek basin; therefore, bluff and terrace erosion was considered to be the main source of sediment to these two streams. No active bluff erosion was observed on the Cranberry River or the Bark River, but anecdotal information suggests that landslides happen occasionally on the Cranberry River. More terrace erosion was observed along the Cranberry River than along the Bark River; therefore, the largest source of sediment to the Cranberry River is thought to be from bluff and terrace erosion, but in lesser amounts than in Whittlesey Creek and the Sioux River. For the Bark River, sources of sediment were somewhat evenly divided among road crossings, terrace erosion, bank erosion, incision of main stems and feeder channels. (Not enough data on sediment loads were available for the Raspberry River to compare to North Fish Creek sediment loads.) Additional studies on sediment transport and source areas are needed to quantify and verify the rough percentages for sediment loadings provided in this study.

Evaluation of past erosion-control techniques indicated that bluff erosion could be reduced by stabilizing the toe at the base of the bluff through a combination of artificial hardening and bioengineering, and reducing mass wasting of the top of the bluffs by grading to stable slope angles. Limited evidence suggests that even though artificial-hardening structures degraded in a few years, this was enough time for the planted vegetation to get a start at building up enough root mass to prevent further erosion. Reduction in mass-wasted material from the top of the bluff also allowed the vegetation to grow on the bluff toe. These bioengineering techniques used alone were not adequate to reduce toe erosion.

Base-flow measurements and a groundwater-flow model for the Bayfield Peninsula indicate that headwaters do not receive groundwater contributions from the deep aquifer system that is recharged through the permeable sands in the center of the Bayfield Peninsula. Instead, base flow is unevenly distributed among the streams within and among basins depending on the proximity of the channels to groundwaterdischarge zones from the deep aquifer system. Groundwater contributing areas for the five studied streams are not the same as surface-water-contributing areas. About 89 percent of total recharge to the deep aquifer system discharges to Bayfield Peninsula streams; the remaining 11 percent discharges to Lake Superior.

Available and potential brook-trout habitat is dependent on the location of groundwater-discharge zones, the size of flood peaks, and the sediment load. Management practices focused on reducing runoff from upland areas (increasing roughness) and increasing channel roughness in upper main stems will potentially reduce flood peaks, shear stress, and sediment loads along main-stem channels. It must be kept in mind; however, that these streams are dynamic systems that will continue to have geomorphic changes. Management practices are best implemented with an understanding of geomorphic processes within the context of their longitudinal positions within their drainage networks. These processes may produce undesirable erosion in some locations, but can produce pools, increase channel complexity, and renew gravel and spawning beds in other locations.

\section{Acknowledgments}

The Bayfield Stream Assessment Partnership Team, led by Laura Hewitt and later continued by Todd Breiby (Trout Unlimited), was influential at guiding the goals and approach of this study. The partnership consists of Gerald Bauman (Windway Capital Corporation, Sheboygan, Wis.), Diane Dalton (ABDI-LCD, Ashland, Wis.), Pam and Mark Dryer (U.S. Fish and Wildlife Service, Ashland, Wis.), Michael Gardner (Sigurd Olson Environmental Institute, Northland College, Ashland, Wis.), Brian Graber (Water Resources Consulting, Boston, Mass.), Gary Haughn (NRCS, Ashland, Wis.), William Heart (Wild Rivers Chapter, Trout Unlimited), Michael Kroenke, (University of Wisconsin-Extension, Ashland, Wis.), Leah La Pointe (Red Cliff Tribe, Red Cliff, Wis.), Marty Melchior, (Inter-Fluve, Inc., Lake Mills, Wis.), Lee Newman (USFWS), Dennis Pratt, and Faith Fitzpatrick.

Our thanks to James Rauman (USGS, Madison, Wis.) for Geoprobe coring assistance and Thomas Popowski (USGS, Rice Lake, Wis.) for assisting with base-flow survey and operation and maintenance of the streamflow-gaging stations. Mike Gardner, Diane Dalton, and Eric Maki (ABDI-LCD, Ashland, Wis.) assisted in evaluating sites with previous erosion-control techniques. Watershed delineation and GIS work was done with assistance from James Kennedy (USGS, Middleton, Wis.), Cheryl Buchwald (USGS, Middleton, Wis.), and Rebecca Woll (USGS, Middleton, Wis.).

For historical insights into channel changes, logging and farming practices, and site access we are thankful to Bonnie Davis, Sylvester Franchek, Thomas Galligan, James Held, Stewart Isaksson, Florence Koleski, and Dale Paulson. We also thank Gerald Bauman for doing the helicopter video surveys and Terry Kohler (Windway Capital Corp.) for donating Mr. Bauman's time and helicopter use.

Martin Melchior and Brian Graber provided technical assistance and insights into geomorphic characteristics and processes, sources of sediment, and fish passage. The manuscript was improved on the basis of technical reviews provided by John Moody (USGS, Denver, Colo.), Paul Juckem (USGS, Middleton, Wis.), Ulf Gafvert (National Park Service, Ashland, Wis.), Martin Melchior, and Brian Graber. Editorial review was done by Mary Ashman (USGS, Northborough, Mass.). 


\section{References Cited}

Alexander, G.R., and Hansen, E.A., 1986, Sand bed load in a brook trout [Salvelinus fontinalis] stream: North American Journal of Fisheries Management, v. 6, no. 1, p. 9-23.

American Society of Civil Engineers, 1949, Hydrology Handbook: American Society of Civil Engineers, Manuals of Engineering Practice, No. 28, New York, p. 106.

Andrews, S.C., Christensen, R.G., and Wilson, C.D., 1976, Impact of Nonpoint Pollution Control on Western Lake Superior: Red Clay Project: Work Plan: Environmental Protection Agency 905/9-76-002, 175 p.

Andrews, S.C., Houtman, D.S., and Lontz, W.J., 1979, Impact of Nonpoint Pollution Control on Western Lake Superior: Red Clay Project Final Report: Summary: Environmental Protection Agency 905/9-79-002, 32 p.

Benchmark GIS, 2001, Digital Elevation Model: Chapel Hill, N.C., scale 1:24,000.

Birkland, P.W., 1984, Soils and geomorphology: Oxford University Press, New York, 372 p.

Bowers, 1900, Artificial propagation of Atlantic salmon, rainbow trout, and brook trout: U.S. Commission of Fish and Fisheries, p. 62.

Brown, K., 2000, Urban Stream Restoration Practices: An Initial Assessment. Final Report: Ellicott City, Md., Center for Watershed Protection, $125 \mathrm{p}$.

Buchanan, T.J., and Somers, W.P., 1984, Discharge measurements at gaging stations: U.S. Geological Survey Techniques of Water-Resources Investigations, book 3, chap. A8, $65 \mathrm{p}$.

Cannon, W.F., Woodruff, L.G., Nicholson, S.W., and Hedgman, C.A., 1996, Bedrock geologic map of the Ashland and the northern part of the Ironwood, 30' X 60' quadrangles, Wisconsin and Michigan: U.S. Geological Survey Miscellaneous Investigations Series Map I-2566, scale 1:100,000.

Chang, H.H., 1992, Fluvial processes in river engineering: Malabar, Florida, Krieger Publishing Company, 432 p.

Clayton, Lee, 1984, Pleistocene geology of the Superior Region, Wisconsin: Wisconsin Geological and Natural History Survey Information Circular 46, $40 \mathrm{p}$.

Eichenlaub, V.L., 1979, Weather and climate of the Great Lakes region: Notre Dame, University of Notre Dame Press, $335 \mathrm{p}$.

Engman, E.T., 1986, Roughness coefficients for routing surface runoff: Journal of Irrigation and Drainage Engineering, v. 112 , no. 1, p. $39-53$.
Extension Service of College of Agriculture, University of Wisconsin-Madison, 1942, Drain level lands: Stencil Circular 230, September 1942, Madison, Wis., 9 p.

Fischenich, C., 2001, Stability thresholds for stream restoration materials: EMRRP Technical Notes Collection (ERDC TN-EMRRP-SR-29), Vicksburg, MS, U.S. Army Engineer Research and Development Center, $10 \mathrm{p}$.

Fitzpatrick, F.A., 1998, Geomorphic and hydrologic responses to vegetation, climate, and base level changes, North Fish Creek, Wisconsin: Madison, Wis., University of WisconsinMadison, Ph.D. dissertation, 275 p.

Fitzpatrick, F.A., and Knox, J.C., 2001, Spatial and temporal sensitivity of hydrogeomorphic response and recovery to deforestation, agriculture, and floods: Physical Geography, v. 21 , no. 2 , p. $89-108$.

Fitzpatrick, F. A., Knox, J. C., and Whitman, H. E., 1999, Effects of historical land-cover changes on flooding and sedimentation, North Fish Creek, Wisconsin: U.S. Geological Survey Water-Resources Investigations Report 99-4083, $12 \mathrm{p}$.

Gardner, M., and Johnson, P.W., circa 1997, Whittlesey Creek Watershed Project, Bayfield County, Wis.: Streambank Stabilization \& Restoration Demonstration Project Report, Ashland Land and Conservation Office unpublished report, Ashland, Wis., 27 p.

Goebel, J.E., Mickelson, D.M., Farrand, W.R., Clayton, L., Knox, J.C., Cahow, A., Hobbs, H.C., and Walton, M.S., Jr., 1983, Quaternary geologic map of the Minneapolis 4 x 6 quadrangle, United States: U.S. Geological Survey Miscellaneous Investigations Series, Map 1-1420(NL-15), scale $1: 1,000,000$.

Greene, C.W., 1935, The distribution of Wisconsin fishes: Wisconsin Conservation Committee, 235 p.

Hack, J.T., 1960, Interpretation of erosional topography in humid temperate regions: American Journal of Science, v. 5, p. 258-A, p. $80-97$.

Hack, J.T., 1965, Postglacial drainage evolution and stream geometry in the Ontonagon area, Michigan: U.S. Geological Survey Professional Paper 504-B, $40 \mathrm{p}$.

Haitjema, H.M., 1995, Analytic element modeling of groundwater flow: Academic Press, San Diego, 394 p.

Highway Research Board, 1970, Scour at Bridge Waterways: National Cooperative Highway Research Program, Synthesis of Highway Practice, Washington D.C., Report No. 5, $37 \mathrm{p}$. 
Hole, F.D., Beatty, M.T., Milfred, C.J., Lee, G.B., Klingelhoets, A.J., Sale, R.D., and Liu, J.T., 1968, Overlay soil map of Wisconsin: Madison, Wis., University of Wisconsin, Geological and Natural History Survey, Madison, Wis., scale 1:250,000.

Huff, F. A. and Angel, J.R., 1992, Rainfall Frequency Atlas of the Midwest, Bulletin 71, Midwestern Climate Center Research Report 92-03, 140 p.

Hunt, R.J., Anderson, M.P., and Kelson, V.A., 1998, Improving a complex finite-difference ground water flow model through the use of an analytic element screening model: Ground Water, v. 36, no. 6, p. 1011-1017.

Hunt, R.J., Haitjema, H.M., Krohelski, J.T., and Feinstein, D.T., 2003, Simulating groundwater-lake interactions: approaches and insights: Groundwater, v. 41, no. 2, p. $227-237$.

Hunt, R.J., and Krohelski, J.T., 1996, The application of an analytic element model to investigate groundwater lake interactions at Pretty Lake, Wisconsin: Journal of Lake and Reservoir Management, v. 12, no. 4, p. 487-495.

Hunt, R.J., Lin, Y., Krohelski, J.T., and Juckem, P.F., 2000, Simulation of the shallow hydrologic system in the vicinity of Middle Genesee Lake, Wisconsin, using analytic elements and parameter estimation: U.S. Geological Survey, Water Resources Investigations Report 00-4136, 16 p.

Inter-Fluve, Inc. and Graber, B., 2003, Bayfield Peninsula stream assessment, final report: fluvial geomorphology, hydrology, and management recommendations: Lake Mills, Wisconsin, Inter-Fluve, Inc., variable pagination.

Knighton, D., 1998, Fluvial forms and processes: New York, Oxford University Press, Inc., 383 p.

Leach, Glen, C., 1923, Artificial propagation of brook trout and rainbow trout, with notes on three other species: Appendix IV to the report of the U.S. Commissioner of Fisheries for 1923, Bureau of Fisheries Document No. 955, 74 p.

Lenz, B.N., Saad, D.A., and Fitzpatrick, F.A., 2003, Simulation of ground-water flow and rainfall runoff with emphasis on the effects of land cover, Whittlesey Creek, Bayfield County, Wisconsin, 1999-2001: U.S. Geological Survey Water-Resources Investigations Report 03-4130, 47 p.

Leopold, L.B., Wolman, M.G., and Miller, J.P., 1964, Fluvial processes in geomorphology: San Francisco, W.H. Freeman and Company, $522 \mathrm{p}$.

Milfred, C.J., Olson, G.W., and Hole, F.D., 1967, Soil resources and forest ecology of Menominee County, Wisconsin: University of Wisconsin, Geological and Natural History Survey, Soil Survey Division, Bulletin 85, Soil Series No. 60: Madison, Wis., 203 p. and 3 plates.
Montgomery, D.R., and Buffington, J.M., 1997, Channel-reach morphology in mountain drainage basins: Bulletin of the Geological Society of America, v. 109, no. 5, p. 596-611.

Morey, G.B., and Ojakangas, R.W., 1982, Keeweenawan sedimentary rocks of eastern Minnesota and northwestern Wisconsin, in Wold, R.J., and Hinze, W.J., eds., Geology and tectonics of the Lake Superior basin: Geological Society of America Memoir 156, p. 135-146.

Mudrey, M.G., Brown, B.A., and Greenberg, J.K., 1982, Bedrock geologic map of Wisconsin: Wisconsin Geological and Natural History Survey, scale 1:1,000,000.

Munsell Color, 1975, Munsell soil color charts, Baltimore, Munsell color Division of Kollmorgen Corp., variable pagination.

Natural Resources Conservation Service, 2006, Soil Survey of Bayfield County, Wisconsin.

Newman, L.E., DuBois, R.B., and Halpern, T. (editors), 1999, A brook trout rehabilitation plan for Lake Superior: Ann Arbor, Mich., Great Lakes Fisheries Commission, 25 p.

Poeter, E.P., and Hill, M.C., 1998, Documentation of UCODE, a computer code for universal inverse modeling: U.S. Geological Survey Water-Resources Investigations Report 98-4080, 116 p.

Pratt, D., 2000, Lake Superior Basin brook trout management plan-2000; Superior, Wis., Wisconsin Department of Natural Resources (October 2000 Draft), 20 p.

Red Clay Interagency Committee, 1957, Whittlesey watershed: a report: Madison, Wis., Soil Conservation Board, $32 \mathrm{p}$.

Red Clay Interagency Committee, 1960, Whittlesey watershed: a progress report: Madison, Wis., Soil Conservation Board, 20 p.

Red Clay Interagency Committee, 1964, Second progress report: Madison, Wis., Soil Conservation Board, 40 p.

Red Clay Interagency Committee, 1967, Erosion and sedimentation control on the red clay soils of northwestern Wisconsin: Madison, Wis., Soil Conservation Board, 23 p.

Red Clay Inter-Agency Committee, 1971, Preliminary report: erosion and sedimentation control, Lake Superior Basin, Wisconsin: Madison. Wis., Soil Conservation Board, variable pagination.

Red Clay Inter-agency Committee, 1972, Erosion and sedimentation in the Lake Superior Basin: Madison, Wis., Wisconsin Department of Natural Resources, $81 \mathrm{p}$.

Red Clay Interagency Committee, 1977, 1976 Evaluation of RCIC works project: Madison, Wis., Soil Conservation Board, 56 p. 
Reese, H.M., Lillesand, T., Nagel, D.E., Stewart, J.S., Goldmann, R.A., Simmons, T.E., Chipman, J.W., and Tessar, P.A., 2002, Statewide land cover derived from multiseasonal Landstat TM data-A retrospective of the WISCLAND project: Remote Sensing of Environment, v. 82, p. 224-237.

Retallick, G., 1985, Laboratory exercises in paleopedology: Course Handout, University of Oregon, Eugene, 74 p.

Rose, W.J., and Graczyk, D.J., 1996, Sediment transport, particle size, and loads in North Fish Creek in Bayfield County, Wisconsin, Water Years 1990-91: U.S. Geological Survey Water-Resources Investigations Report 95-4222, 18 p.

Rosgen, D., 1996, Applied River Morphology, Pagosa Springs, Colorado, Wildland Hydrology, variable pagination.

Schumm, S.A., 1977, The Fluvial System: New York, John Wiley and Sons, Inc., 338 p.

Schwarz, G.E., and Alexander, R.B., 1995, State Soil Geographic (STATSGO) Data Base for the conterminous United States (ed. 1.1): U.S. Geological Survey Open-File Report 95-449, geo-dataset on CD-ROM, scale 1:250,000.

Shelton, L.R., and Capel, P.D., 1994, Guidelines for collecting and processing samples of stream bed sediment for analysis of trace elements and organic contaminants for the National Water-Quality Assessment Program: U.S. Geological Survey Open-File Report 94-458, 20 p.

Shields, A., 1936, Anwendung der Aelichkeitsmechanik und der Turbulenzforschung auf die Geschiebebewegung: Mitteilungen der Preussischen Versuchsanstalt fuEr Wasserbau und Schiffbau, Berlin, Germany, translated to English by W.P. Ott and J.C. van Uchelen, California Institute of Technology, Pasadena, Calif.

Silver, Mary, and Lichtenheld, Andy, 2003, Oral history interview with Helen and Jerry Jack on March 28, 2003: U.S. Fish and Wildlife Service unpublished document, Ashland, Wis.

Soil Conservation Service, 1972, National Engineering Handbook, Section 4, Hydrology: U.S. Government Printing Office, Washington D.C., variously paginated.

Soller, D.R., and Packard, P.H., 1998, Digital representation of a map showing the thickness and character of Quaternary sediments in the glaciated United States east of the Rocky Mountains: U.S. Geological Survey Digital Data Series DDS-38, one CD-ROM.

Strack, O.D.L., 1989, Groundwater mechanics: Englewood Cliffs, New Jersey, Prentice-Hall, 732 p.
Thorne, C.R., 1998, Stream reconnaissance handbook: Chichester, West Sussex, John Wiley and Sons, 133 p.

Thwaites, F.T., 1911, Geological map of part of west end of Lake Superior: Wisconsin Geological and Natural History Survey, scale 1:190,080.

U.S. Army Corp of Engineers, 1998, HEC-1 Flood hydrograph package-User's manual: U.S. Army Corps of Engineers, Hydrologic Engineering Center, Version 4.1, April 1991, 433 p.

U.S. Department of Agriculture, Natural Resources Conservation Service, (in press), Soil survey for Bayfield County, GIS-based map, scale 1:12,000.

U.S. Department of Agriculture, Soil Conservation Service, 1983, National Engineering Handbook, Section 3, Sedimentation: U.S. Department of Agriculture, Soil Conservation Service 210-VI-NEH-03, variable pagination.

U.S. Department of Agriculture, Soil Conservation Service, 1986, Urban hydrology for small watersheds: U.S. Department of Agriculture, Soil Conservation Service, Technical Release 55, variable pagination.

U.S. Department of Agriculture, Soil Conservation Service, Soil Survey Staff, 1951, Soil survey manual, U.S. Department of Agriculture, Agricultural Handbook No. 18, Washington, D.C., 503 p.

Young, H.L., and Skinner, E.L., 1974, Water resources of Wisconsin-Lake Superior Basin: U.S. Geological Survey Hydrologic Investigations Atlas HA-524, 3 sheets.

Vanoni, V.A., (ed.) 1975, Sedimentation engineering: New York, American Society of Civil Engineers, 745 p.

Verry, E.S., 1987, The effect of aspen harvest and growth on water yield in Minnesota: Forest Hydrology and Watershed Management, Proceedings of the Vancouver Symposium, August 1987, p. 553-562.

Wisconsin Department of Natural Resources and U.S. Fish and Wildlife Service, 2005, Wisconsin Lake Superior Basin Brook Trout Plan: Ashland, Wis., Wisconsin Department of Natural Resources, May 2005, 47 p.

Wisconsin Department of Agriculture and Wisconsin Geological and Natural History Survey, 1928, Land economic survey: Bayfield County, Wis., scale 1:63,360.

Wolman, M.G., 1954, A method of sampling coarse river-bed material: Transactions of the American Geophysical Union, v. 35, no. 6, p. 951-956. 
Publishing support provided by the U.S. Geological Survey Science Publishing Network, Columbus and Rolla Publishing Service Centers

For more information concerning the research in this report, contact: Director, Wisconsin Water Science Center

U.S. Geological Survey

8505 Research Way

Middleton, Wisconsin 53562

http://wi.water.usgs.gov/ 


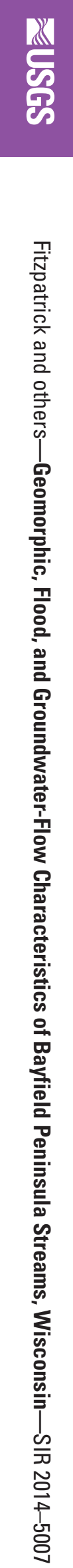